Pedagogika Szkoły Wyższej 



\author{
UNIWERSYTET SZCZECIŃSKI \\ WYDZIAL HUMANISTYCZNY \\ INSTYTUT PEDAGOGIKI
}

\title{
Pedagogika \\ Szkoły \\ Wyższej
}

$2(10) / 2015$

SZCZECIN 2015 


\title{
Rada Naukowa
}

Teresa Bauman, Maria Czerepaniak-Walczak, Barbara Kromolicka, Zbigniew Kwieciński, Mieczysław Malewski, Urszula Ostrowska,

Ivana Pirohová, Maria Wójcicka, Vaiva Zuzevičiūtè

\section{Redakcja}

Anna Murawska (redaktor naczelny), Ilona Kość (sekretarz), Maksymilian Chutorański, Anita Karyń, Janina Świrko-Pilipczuk, Paula Wiażewicz-Wójtowicz, Julia Karapuda (www)

\section{Lista recenzentów znajduje się na stronie czasopisma www.psw.whus.pl}

\author{
Redaktor tomu \\ Janina Świrko-Pilipczuk \\ Redaktor językowy
}

Korektor

Skład komputerowy

Agnieszka Kozioł

\section{Projekt okładki}

Paweł Kozioł

\section{Adres redakcji}

71-431 Szczecin, ul. Ogińskiego 16/17

tel. 914443769,914443747

e-mail:psw@whus.pl

\section{Wersja papierowa jest wersją pierwotną}

Streszczenia opublikowanych artykułów są dostępne online w międzynarodowej bazie danych The Central European Journal of Social Sciences and Humanities http://cejsh.icm.edu.pl oraz w CEEOL

(C) Copyright by Uniwersytet Szczeciński

ISSN 2083-4381

\section{WYDAWNICTWO NAUKOWE UNIWERSYTETU SZCZECIŃSKIEGO}

Wydanie I. Ark. wyd. Ark. druk. Format 170/240. Nakład egz. 


\section{SPIS TREŚCI}

\section{STUDIA I ROZPRAWY}

MAREK REMBIERZ, Uniwersytet - mąrość - bezinteresowność.

Tradycyjny etos $i$ współczesne przemiany tożsamości

uniwersytetu

ANNA SAJDAK, Nauczyciel akademicki-dylematy, napięcia, ambiwalencja roli. 49

\section{DYSKUSJE, OPINIE}

JACEK MOROZ, Czy dialog sokratejski może być konstruktywistyczny 69

SYLWIA JASKULSKA, Pop-rytualne oblicze uczelni wyższych 79

ANNA WACH-KĄKOLEWICZ, MARIUSZ KĄKOLEWICZ, Portfolio uczenia się jako narzędzie wspomagajace rozwój kompetencji do nauczania młodej kadry pedagogicznej 99

\section{DONIESIENIA Z BADAŃ}

ANNA KARPIŃSKA, Niepowodzenia szkolne $w$ retrospekcji studentów pedagogiki.

JANUSZ ŚLUSARSKI, Inteligencja społeczna nauczycieli akademickich a ich ukryte teorie na temat osobowości studentek/studentów

KATARZYNA WOJCIECHOWSKA, Determinanty różnicujące poczucie sensu życia studentów 
HUBERT KUPIEC, Dialog w kształceniu pedagogicznym studentów resocjalizacji.

REGINA PAZDUR, Student/studentka pedagogiki człowiekiem (bez) nadziei?

TERESA JOANNA ANDRZEJEWSKA, Uczelnia jako miejsce współpracy opiekuna naukowego/promotora i doktoranta 195

\section{PRAKTYKI}

HUSSEIN BOUGSIAA, Mobile Learning Concept and Infrastructure in Higher Education / Pojecie mobilnego uczenia się.

Infrastruktura m-learning w edukacji wyższej....

ANDRZEJ MARCINIUK, Kształcenie specjalne personelu latajacego $w$ „Szkole Orlat” w latach 1925-1939. 229

\section{INFORMACJE, RECENZJE}

OXANA KOZLOVA, Świat korowodu

BARBARA CHOJNACKA, JULIA MAGDALENA KARAPUDA, Sprawozdanie z XXIX Letniej Szkoły Młodych Pedagogów, 14-19 września 2015 r., Pułtusk-Warszawa 


\section{CONTENTS}

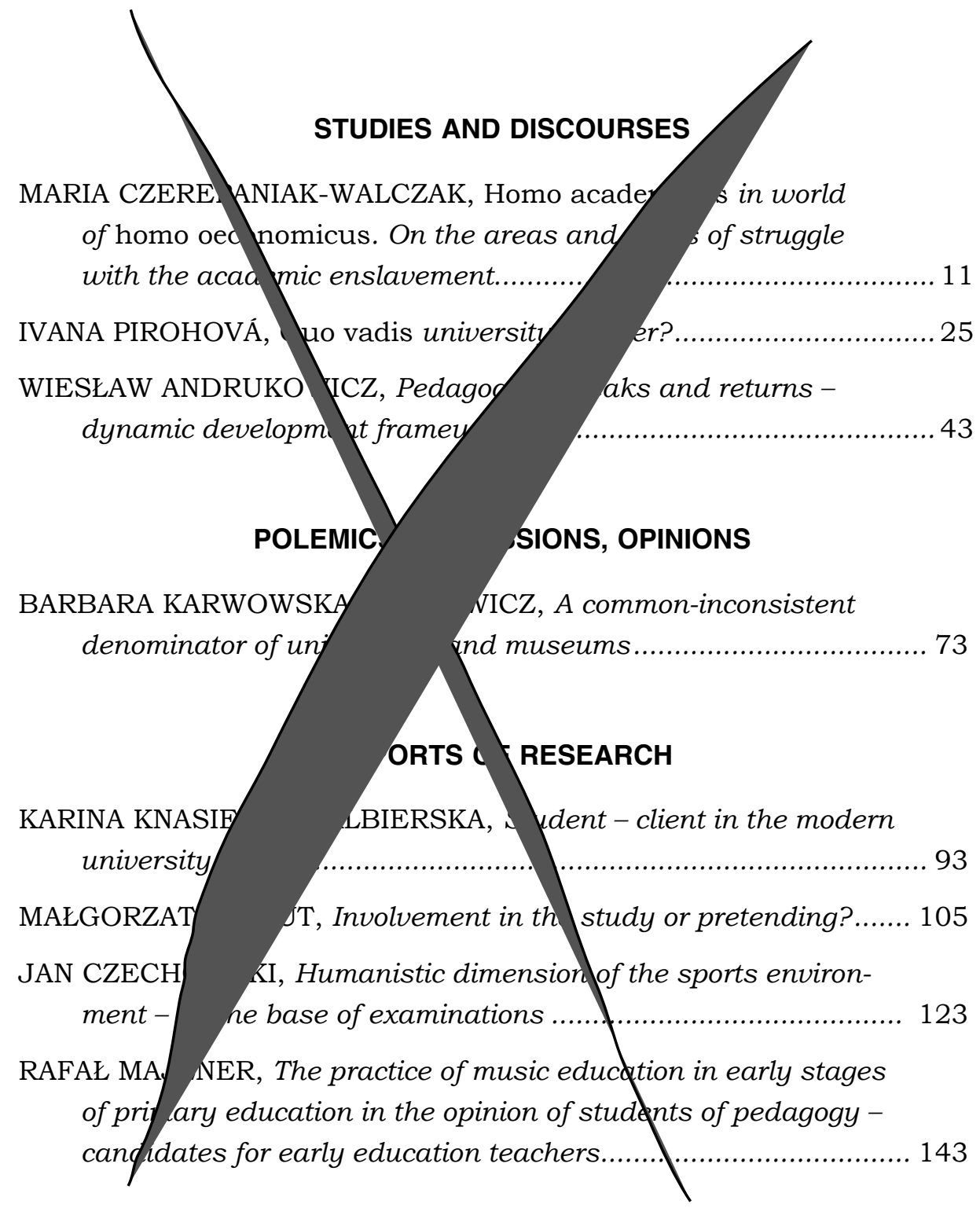




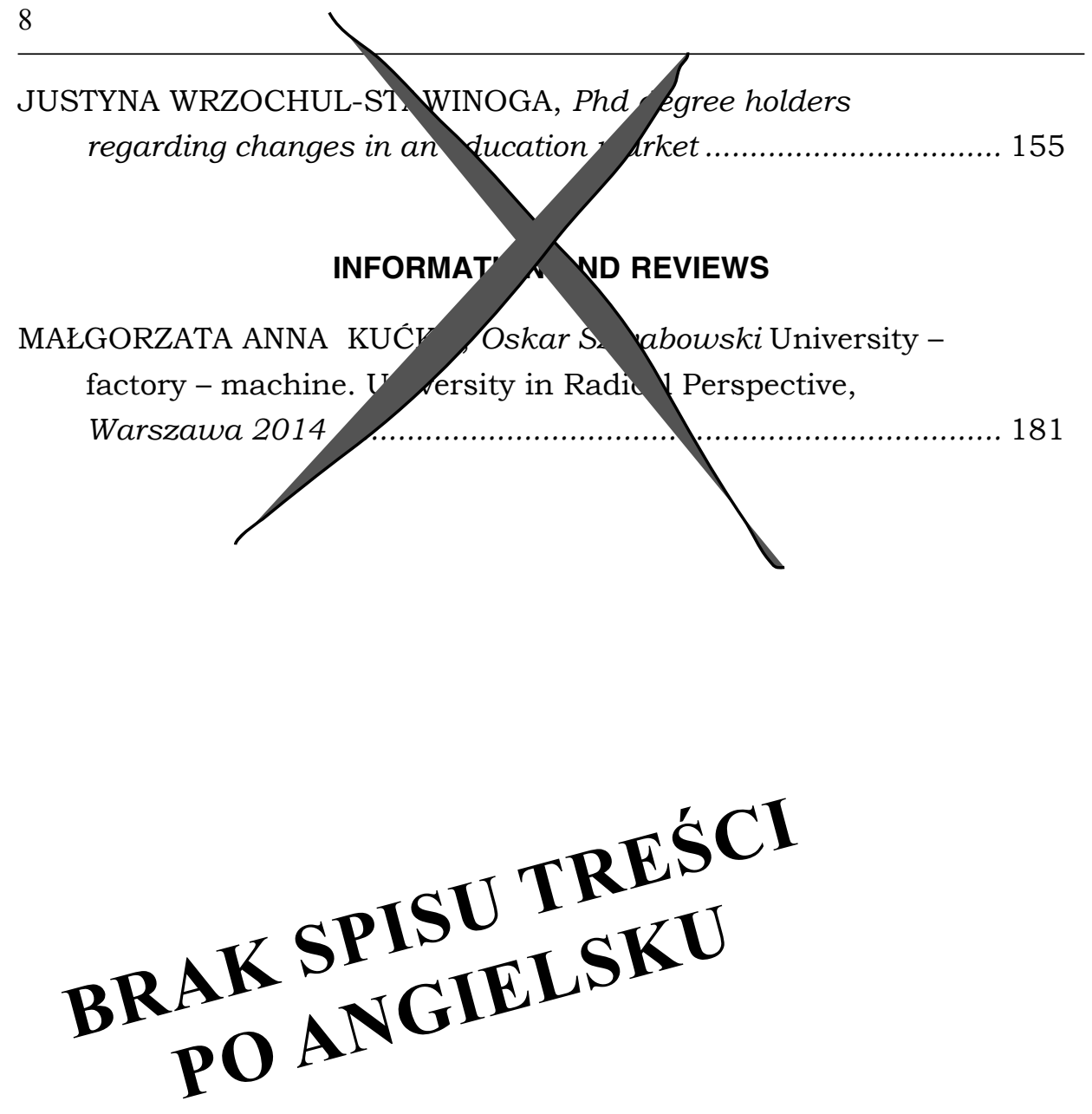




\section{STUDIA I ROZPRAWY}





\section{Marek Rembierz}

Uniwersytet Śląski

\section{Uniwersytet - wolność - bezinteresowność. Tradycyjny etos i współczesne przemiany tożsamości uniwersytetu}

Wspótczesny uniwersytet cierpi więc na rozdwojenie jaźni: kołacze się $w$ nim jeszcze myśl o misji służenia pełnej prawdzie, a próbuje przybrać postać firmy usługowej, $w$ ramach której tej misji realizować nie może.

Agnieszka Lekka-Kowalik ${ }^{1}$

[...] na współczesnym uniwersytecie ścieraja się dwa porzadki - Prometeusza i Hermesa. Pierwszy oddaje ducha idei uniwersytetu nastawionego na poszukiwanie prawdy i rozwijanie krytycyzmu, drugi - podporzadkowany prawom rynku-dą̇y do osiagnięcia doraźnych, efektywnych celów.

Maria Czerepaniak-Walczak ${ }^{2}$

Naczelna powinnościa uniwersytetu $w$ cywilizacji wiedzy, czyli $w$ warunkach ksztattujacego się społeczeństwa opartego na wiedzy, jest "troska o człowieczeństwo”.

Kazimierz Denek ${ }^{3}$

Społeczność akademicka ma niezbywalne prawo i obowiazek bycia liderem szerzenia, umacniania, obrony uniwersytetu jako wyjątkowej wartości.

Kazimierz Denek ${ }^{4}$

Obecnie coraz intensywniej toczy się publiczna debata o zachodzacych przemianach w funkcjonowaniu uniwersytetu i o pożądanych kierunkach tych przemian. Formułuje się różnego rodzaju praktyczne postulaty i dalekosiężne strategie, aby uniwersytet skutecznie odnajdywał

1 A. Lekka-Kowalik, Uniwersytet jako firma usługowa - szansa czy klęska?, „Ethos” 2009, nr 85-86, s. 66.

2 M. Czerepaniak-Walczak, Uczenie sie czy studiowanie? Niektóre aspekty procesu bolońskiego, w: Wprowadzenie do pedagogiki szkoły wyższej, red. K.W. Jaskot, In Plus, Szczecin 2006, s. 414.

3 K. Denek, Ku modernizacji uniwersytetu, „Forum Akademickie” 2009 nr 2, s. 47-48.

4 K. Denek, Uniwersytet. Między tradycja a wyzwaniami współczesności i przyszłości, „Edukacja Humanistyczna” 2013, nr 1 (28), s. 9. 
się w dynamicznie zmieniającej się rzeczywistości społecznej. Przyjmuje się przy tym - jawnie bądź skrycie - określone założenia aksjologiczno -antropologiczne fundujące idee i funkcje uniwersytetu, założenia, które przesadzaja o dokonywanym w praktyce życia społecznego wyborze promowanych i urzeczywistnianych - jak też odsuwanych na dalszy plan lub eliminowanych - zestawów wartości. Wskazywanie „pożądanych kierunków zmian” w funkcjonowaniu uniwersytetu i ocena „skutecznego odnajdywania się we współczesności" sa przede wszystkim zależne od świadomie lub nieświadomie uznawanych kryteriów, wedle których dokonuje się osądu i wartościowania sytuacji. Można słusznie domniemywać, że nie wszyscy spośród wypowiadających się o uniwersytecie mają na myśli ten sam stan rzeczy; używający tak samo brzmiących słów mówia jednak o czymś innym - częstokroć radykalnie innym - i maja na względzie inne interesy (także przeciwstawne) niż swoisty interes i swoiste wartości uniwersytetu. Arbitralnym aktem woli grupy rządzącej zazwyczaj przyjmuje się $\mathrm{w}$ sferze polityki i zespolonych $z$ nią zarządzeń administracyjnych to, co należy uznawać za „obiektywne czynniki” wyznaczające pożądane walory i niepożądane niedomagania uniwersytetu, a następnie perswazyjnie narzuca się te zalecenia i przepisy prawne społeczności akademickiej jako jej sferę „,społecznej odpowiedzialności” i jej aktualne powinności wobec społeczeństwa, do których spełniania zostaje zobowiązana. W zwiąku z takimi koncepcjami i poczynaniami dotyczacymi samych podstaw funkcjonowania uniwersytetu i szkolnictwa akademickiego powstaje wiele istotnych kwestii spornych i zarazem wiele nieporozumien, które bywaja wszakże skrzętnie pomijane lub instrumentalnie wykorzystywane przez narzucających - zwłaszcza urzędowo wymuszających - swój punkt widzenia na sprawy uniwersytetu i sposób ich rozstrzygania.

Tocząca się debata o współczesnej tożsamości uniwersytetu niesie z soba też dalsze poważne trudności. Nie skupia się bowiem ona tylko na porównawczym ujęciu dawnej i współczesnej tożsamości uniwersytetu, na pytaniach o sens i istotę uniwersyteckości w kontekście aktualnych wyzwań, ale dotyczy zarazem - szeroko pojętych - zmian cywilizacyjnych, ponieważ w te złożone i w dużej mierze nieprzejrzyste procesy - jakby samorzutnie i nieodłącznie - zdaje się być uwikłana aktualna sytuacja uniwersytetu i przyszłość jego funkcjonowania. Jednak rodzaj i skala uwikłania uniwersytetu w procesy przemian cywilizacyjnych moga 
być radykalnie mityzowane, sprowadzane do „wszystko wyjaśniających” schematów, moga stać się przedmiotem ideologicznych wmówień, iż jedynie taki, a nie inny jest dziejowy (np. ekonomiczny, globalizacyjny) determinizm, któremu uniwersytet musi ulec, gdyż nie ma innej alternatywy i nikt nie jest w mocy dyskutować $z$ nieodwracalna koniecznościa. W takim zdecydowanie deterministycznym podejściu co do przebiegu cywilizacyjnych przemian dominuje przekonanie (quasi-religijna wiara), iż przemiany te w pełni określaja, jaki może być i jaki faktycznie będzie uniwersytet, co zarazem radykalnie redukuje pole rzetelnego namysłu, wyjaławia wyobraźnię, ubezwłasnowolnia refleksję i wręcz unieważnia znaczenie swobodnej, akademickiej dyskusji jako podstawowej metody wiedzotwórczej. To nie uniwersytet ma rozpoznawać dokonujące się przemiany i wypracowywać ich modele, ale ma być jedynie bezwolnym przedmiotem tych przemian, a także ma ulec presji politycznie dominujących wyznawców bezdyskusyjnie słusznej (w danym momencie) wizji tych przemian. Przy takim podejściu jedyne, co pozostaje, co jawi się jako dopuszczalne i racjonalne, to powierzyć i zawierzyć uniwersytet pragmatycznie działajacym menedżerom, którzy trafnie rozumieja „ducha dziejów" i uczynia uniwersytet taka instytucja, taka korporacja, jaka on powinien być w zgodzie $z$ wymaganiami (zwłaszcza ekonomicznymi) tegoż „ducha”. A ci, którzy sa takiemu postępowaniu póki co przeciwni, albo poddadzą się reedukującym ich szkoleniom, nabędą niezbędnych kwalifikacji i wpisza się w obowiązujące ramy uczelnianej działalności, albo zostana skwitowani mianem „starodawnego pięknoducha”, dla którego wszakże - jako istoty niewykazującej aktualnie wymaganych kompetencji, kwalifikacji i postaw oraz nierozumiejącej należycie wymagań „ducha dziejów" - nie ma miejsca w granicach współczesnego uniwersytetu jako instytucji podporzadkowanej determinizmowi przemian cywilizacyjnych. Ta narracja o dostosowawczej reedukacji (albo wykluczeniu ze struktur uniwersytetu) brzmi może nazbyt kasandrycznie i złowieszczo, ale autor przedkładanego tekstu - ku swemu wielkiemu zaskoczeniu - osobiście zetkną się (po wygłoszeniu referatu o zasadach uniwersyteckiej wolności) $z$ tak dobitnie wyartykułowanym „albo-albo” i z dyskredytujacym mianem „pięknoducha” skierowanym pod jego adresem. Co okazało się wszakże - w dłuższej perspektywie czasu - pouczającym doświadczeniem i „szczęśliwą winą" (felix culpa), gdyż trwale uwrażliwiło na intelektualny 
wymóg i praktyczna doniosłość podejmowania wciąż na nowo refleksji nad aktualnością tradycyjnego etosu uniwersytetu w kontekście współczesnych przemian jego tożsamości ${ }^{5}$.

Aby wyostrzyć obraz podjętych tu problemów, rozpocznę od przywołania istotnych uwag o wolności nauczania i wolności studiowania, które poczynił Tadeusz Kotarbiński (1886-1981)6, gdy wspominał swa aktywność profesorska w czasie okupacji hitlerowskiej w ramach działalności podziemnego Uniwersytetu Warszawskiego:

Wykłady i ćwiczenia tym się różniły od zwykłych, że odbywały się $\mathrm{w}$ prywatnych mieszkaniach (do jakich klitek wtedy uniwersytet nie sięgał!), w małych, kilku- lub kilkunastoosobowych gronach, i że ich uczestnikami byli gorliwcy, którzy studiowali, bo chcieli, choć nikt ich nie zmuszał do korzystania $z$ możliwości studiów. I jeszcze jedno: do programu nikt się nie wtrącał, profesor brał na siebie odpowiedzialność za przedmiot i oczywiście obce było uczestnikom tej nielegalnej, przejętej duchem wolności uczelni jakiekolwiek ideologicznie cenzurowanie

5 Wart uwzględnienia (i być może upowszechnienia) jest postulat systematycznego uprawiania - pojętego interdyscyplinarnie - „uniwersytetoznawstwa”. Postulat ten - z punktu widzenia naukoznawstwa i ogólnej metodologii nauk - sformułował Stanisław Majdański. Zob. S. Majdański, O autorytecie i idei uniwersytetu (z refleksji naukoznawczej), „Summarium" 2009, nr 38 (58), s. 63-80. Z prac wpisujacych się w nurt badań uniwersytetoznawczych zob. m.in.: T. Lewowicki, O modelu szkolnictwa wyższego - uniwersytecka tradycja, przemiany, problemy $i$ sugestie rozwiazań, „Ruch Pedagogiczny” 2012, nr 4, s. 9-24; Uniwersytety. Tradycje - dzień dzisiejszy - przyszłość, red. Z. Drozdowicz, Wyd. UAM, Poznań 2009; Z. Drozdowicz, Excellentia Universitas. Szkice o uniwersytecie, Wyd. Fundacji Humaniora, Poznań 1995; L. Kołakowski, Po co uniwersytet?, w: L. Kołakowski, Czy Pan Bóg jest szczęśliwy?, wybór Z. Mentzel, Znak, Kraków 2009, s. 259-267; P. Sztompka, Uniwersytet współczesny: zderzenie dwóch kultur, „Nauka” 2014, nr 1, s. 7-18; L. Sosnowski, Od idei do mitu. Uwagi o współczesnym uniwersytecie, „The Polish Journal of the Arts and Culture" 2014, no. 12 (4), s. 103-114; J. Goćkowski, UNIWERSYTE T i tradycja w nauce, Secesja, Kraków 1999; Z. Melosik, Uniwersytet $i$ społeczeństwo. Dyskursy wolności, wiedzy $i$ władzy, Impuls, Kraków 2009; D. Hejfosz, Edukacja uniwersytecka i kreowanie elit społecznych, Impuls, Kraków 2010; P. Nowak, HodowANIE TROGLODYTów, Fundacja Augusta hr. Cieszkowskiego, Warszawa 2014. Zob. też teksty zebrane w: Uniwersytet i wartości, red. J. Kostkiewicz, Impuls, Kraków 2007; Szkoła wyższa w toku zmian. Debata wokół ustawy z dnia 18 marca 2011 roku, red. J. Kostkiewicz, A. Domagała-Kręcioch, M.K. Szymański, Impuls, Kraków 2011; A. Dziedziczak-Foltyn, Recepcja przemian instytucji szkoły wyższej - szkic o dwóch formacjach w dyskursie naukowym, „Nauka i Szkolnictwo Wyższe” 2014, nr 1-2 (43-44), s. 30-45 (m.in. rozpatrywana jest monodyscyplinarność a interdyscyplinarność dyskusji o uniwersytetach).

6 Zob. M. Rembierz, Ethos edukacji i jej filozoficzny logos. Elementy filozofii edukacji $w$ dociekaniach Tadeusza Kotarbińskiego, „Studia z Filozofii Polskiej”, t. II, red. M. Rembierz, K. Śleziński, Bielsko-Biała-Kraków 2007, s. 342-354. 
lub kierownictwo. O paradoksie! Nigdy nie brałem udziału w nauczaniu tak absolutnie liberalnym, jak... w dobie najcięższej niewoli ${ }^{7}$.

Osobista odpowiedzialność profesora za rozpatrywane zagadnienia i osobista odpowiedzialność studentów za przebieg ich studiów znajduja się u podstaw wolności akademickiej. Osobista odpowiedzialność profesora odgrywa tu fundamentalna rolę, a warto przypomnieć, że polskie słowo „profesor” pochodzi od łacińskiego słowa professor (nauczyciel, retor) i wiąże się je też z łacińskimi słowami professio, czyli oświadczenie publiczne, professus, profiteri, czyli zeznawanie publiczne lub wyznawa$n^{8}{ }^{8}$. Profesor, występujac $z$ wykładem, który prowadzi na katedrze uniwersyteckiej, nie tylko przedstawia jakieś informacje, ale też - przed słuchająca go społecznościa akademicka - niejako publicznie zaświadcza, że sa dobre racje ku temu, aby zasadnie przyjać i rozpatrzyć podane przez niego informacje jako rzetelna wiedzę, która publicznie przedkłada pod refleksję i dyskusję; staje się on świadkiem i autorytetem ${ }^{9}$. Za urzeczywistnianie bezkompromisowo pojętej wolności nauczenia i konsekwentne

7 T. Kotarbiński, $Z$ dziejów podziemnego Uniwersytetu Warszawskiego, w: idem, Prakseologia. Część II, Zakład Narodowy im. Ossolińskich, Wrocław-Warszawa-Kraków 2003, s. 519. O sporach Kotarbińskiego z okresu stalinizmu dotyczacych wolności i socjalistycznej idei nowego uniwersytetu zob. P. Hübner, Kotarbiński versus Chałasiński, https://forumakademickie.pl/fa/2011/04/kotarbinski-versus-chalasinski/ (10.10.2015). Warto również przywołać doświadczenie udziału w nielegalnych (podziemnych) seminariach naukowych (filozoficznych) w czasach reżimu komunistycznego w czeskiej Pradze w latach siedemdziesiatych XX wieku, o którym z pełnym respektem - z perspektywy człowieka Zachodu - pisze angielski filozof Roger Scruton, gdy rozpatruje aktualna (uznana za wysoce niezadowalająca) kondycję uniwersytetu. R. Scruton Koniec uniwersytetu, tłum. D. Chabrajska, „Ethos” 2015, nr 1, s. 59-62. Zob. też: W. Theiss, Universitas, czyli wspólnota oporu w czasach PRL-u (szkic zagadnienia), w: Innowacje $w$ edukacji akademickiej: szkolnictwo wyższe w procesie zmiany, red. J. Piekarski, D. Urbaniak-Zając, Wyd. UŁ, Łódź 2010, s. 225-234.

8 Zob. A. Murawska, O idei uniwersytetu, kompetencjach nauczycieli akademickich oraz nadziei i prawdzie, „Pedagogika Szkoły Wyższej” 2001, nr 17, s. 71-75; R. Kleszcz, O godności nauczyciela akademickiego, „Nauka - Etyka - Wiara” 2011, s. 392-402; J.J. Jadacki, Misja profesora uniwersytetu, „Uniwersytet Warszawski. Kwartalnik” 2002, nr 2, s. 13-14; idem, Etos akademicki, „Roczniki Filozoficzne” 2005, vol. 53, nr 2, s. 75-81; E. Wysocka, Wyznaczniki roli nauczyciela akademickiego - oczekiwane i realizowane - w percepcji młodzieży studenckiej, w: Edukacja jutra. XI Tatrzańskie Seminarium Naukowe, red. K. Denek, F. Bereźnicki, Instytut Pedagogiki US, Szczecin 2005, s. 277-281; A. Sajdak, Paradygmaty kształcenia studentów i wspierania rozwoju nauczycieli akademickich. Teoretyczne podstawy dydaktyki akademickiej, Impuls, Kraków 2013.

9 Zob. K. Olbrycht, O roli przykładu, wzoru, autorytetu i mistrza $w$ wychowaniu osobowym, Wyd. Adam Marszałek, Torun 2008; L. Witkowski, Wyzwania autorytetu w praktyce społecznej $i$ kulturze symbolicznej (przechadzki krytyczne w poszukiwaniu dyskursu dla 
spełnianie profesorskich powinności w czasie nazistowskiej okupacji płacono bardzo wysoka cenę, włącznie $z$ ryzykiem utraty życia.

Tajne nauczanie oparte na samoorganizacji i samodyscyplinie oraz pozbawione zewnętrznych, administracyjnych ram instytucjonalnych okazuje się modelem i wzorcem etosu „przejętej duchem wolności uczelni”. To paradoksalne doświadczenie wolności akademickiej unaoczniajace, czym w istocie jest studiowanie i nauczanie akademickie, należy przypominać i uwzględniać przy wszelkich próbach politycznych i administracyjnych (wręcz biurokratycznych) regulacji w zakresie funkcjonowania autonomicznego uniwersytetu i innych uczelni akademickich ${ }^{10}$.

Subtelny wywód Kotarbińskiego o zachowaniu wolności akademickiej w kontekście okupacyjnego terroru - przywołany jako kontrast - pozwala uwydatnić niebezpieczeństwa obecnie rozpowszechniajacego się technokratycznego podejścia do funkcjonowania uniwersytetu, niebezpieczeństwa, o których pisze Bogusław Śliwierski:

\begin{abstract}
Uniwersytet w służbie gospodarki rynkowej staje się instytucją instrumentalizująca człowieka, którego godność przejawia się w tym, że jest on środkiem służacym do realizowania obcych mu celów. Władze sa zainteresowane tym, by kreując w sposób antagonistyczny rzeczywistość edukacyjna, wpływać na nia z pozycji jedynie słusznej, prawdziwej, wartościowej własnej ideologii, niezależnie od tego, czy społeczeństwo i środowisko akademickie akceptuje to, czy też nie. Szkoły wyższe w służbie mechanizmów rynkowej rywalizacji stają się zarazem marketingowym produktem naszych czasów ${ }^{11}$.
\end{abstract}

teorii), Impuls, Kraków 2009; idem, Historie autorytetu wobec kultury i edukacji, Impuls, Kraków 2011.

${ }^{10}$ Zob. m.in.: J. Kostkiewicz, Nauka i wolność - wartości fundujace uniwersytet, w: Uniwersytet $i$ wartości; K. Wrońska, Pytanie o wolność $w$ przestrzeni uniwersytetu. Obszary i granice autonomii oraz swobód akademickich - między przywilejem a powinnościa, w: Student na współczesnym uniwersytecie. Ideały $i$ codzienność, red. D. Pauluk, Impuls, Kraków 2010, s. 98-103; D. Ciechanowska, Zmieniajacy się uniwersytet $i$ autonomia studentów, „Edukacja Humanistyczna” 2011, nr 1 (24), s. 37-46; M. Meyer-Blanck, O nowy neohumanizm. Uniwersytet $w$ czasach post-bolońskich, tłum. M. Brudny, weryfikacja tłum. B. Milerski, „Studia z Teorii Wychowania” 2015, t. VI, nr 1 (10), s. 11-17.

${ }^{11}$ B. Śliwerski, Problemy szkolnictwa wyższego - diagnozy i perspektywy, blog „Pedagog” (wpis 27.09.2015), http://sliwerski-pedagog.blogspot.com/2015/09/problemy-szkolnictwa-wyzszego-diagnozy.html (10.10.2015). 
Instrumentalizacja powoduje w pierwszym rzędzie zanik elementarnej bezinteresowności, a uczynienie $z$ uniwersytetu marketingowego produktu niweczy jego - oparty na wielowiekowym doświadczeniu - wewnętrzny świat akademickich wartości.

\section{„Wiraż”, „ruina”, „zmierzch”, „,makdonaldyzacja”i „,przed reanimacją” - próby opisu zmieniającej się sytuacji i tożsamości uniwersytetu}

Obecna sytuację uniwersytetu obrazowo określa się - jak czyni to m.in. wytrawny znawca dydaktyki akademickiej, Kazimierz Denek - jako sytuacje „na wirażu”12. A wiraż to przede wszystkim stan wzmożonego ryzyka i zagrożenia ${ }^{13}, z$ „ostrego zakrętu” - przy braku umiejętności lub uwagi - można bowiem wypaść $z$ trasy, ale można też wyjść wzmocnionym o nowe doświadczenia i umiejętności. Uniwersytet znajdujacy się na wirażu stanowi - zwłaszcza dla pedagogów i filozofów edukacji - wyzwanie do rozważnej, pogłębionej refleksji i rozsądnego działania, a nie do „szarżowania” w imię jakichś modnych „wielkich słów” i ideologicznych wizji (np. „akademickiej doskonałości”, nowomowy „kwalifikacji”) ${ }^{14}$.

${ }^{12}$ K. Denek, Uniwersytet na wirażu, w: Edukacja jutra. Tradycja i nowoczesność we współczesnej organizacji systemu kształcenia, red. K. Denek, A. Kamińska, P. Oleśniewicz, Szkoła Wyższa „Humanitas”, Sosnowiec 2013, s. 25-48. Kazimierz Denek jest autorem m.in. serii artykułów dotyczących funkcjonowania uniwersytetu i dydaktyki akademickiej, które przez wiele lat regularnie publikował na łamach „Pedagogiki Szkoły Wyższej”. Jego rozprawy i studia złożyły się na trzytomowe dzieło: idem, Uniwersytet $w$ perspektywie społeczeństwa wiedzy, cz. 1: Nauka i edukacja w uniwersytecie XXI wieku, Wyd. Wyższej Szkoły Pedagogiki i Administracji im. Mieszka I, Poznań 2011; idem, Uniwersytet w perspektywie społeczeństwa wiedzy, cz. 2: Dydaktyka akademicka i jej efekty, Wyd. Wyższej Szkoły Pedagogiki i Administracji im. Mieszka I, Poznań 2011; idem, Uniwersytet $w$ perspektywie społeczeństwa wiedzy, cz. 3: Przyszłość kształcenia nauczycieli, Wyd. Wyższej Szkoły Pedagogiki i Administracji im. Mieszka I, Poznań 2011. W tej uniwersyteckiej trylogii rozpatruje się m.in. próby przywracania logosu i etosu kształcenia uniwersyteckiego, akcentowanie wartości $\mathrm{w}$ treściach studiów, zasady dydaktyczne procesu kształcenia w uniwersytecie, podstawowe powinności i pożądane cechy nauczycieli akademickich, urynkowienie uniwersytetu; stawia się pytania o etos uniwersytecki, „czy uniwersytet sprosta wyzwaniom?” i „czy następuje ucieczka przed universitas i lęk przed dociekaniem prawdy?”.

${ }^{13}$ Zob. W. Kojs, Zagrożenie jako wyznacznik zmiany edukacyjnej oraz źródeł nakazów, zakazów i powinności, w: Edukacja jutra. IX Tatrzańskie Seminarium Naukowe, red. K. Denek, T. Koszczyc, M. Lewandowski, Wyd. WTN, Wrocław 2003, s. 337-342.

${ }^{14}$ Problematyki tej dotyczą m.in. teksty zebrane w: Przeszkody dla rozwoju humanistyki $w$ szkołach wyższych ( $z$ pedagogika $w$ tle). W perspektywie troski o uniwersytet, kulture humanistyczna i podręcznik, red. M. Jaworska-Witkowska, L. Witkowski, Wyd. Adam Mar- 
Jedno $z$ trafnych obrazowych ujęć niepożądanych aspektów tej sytuacji z uwzględnieniem polskich uwarunkowań końca lat XX i początku XXI wieku zawiera się w ostrzegawczym haśle wypromowanym przez George'a Ritzera ${ }^{15}$ i usytuowanym w polskim kontekście przez Marka S. Szczepańskiego: „McDonald's na uniwersytecie” ${ }^{16}$. Zagrożenie „makdonaldyzacja” polega przede wszystkim na masowym i bezosobowym podawaniu namiastek wiedzy w postaci „fast food”, z zamianą działalności wiedzotwórczej uniwersytetu $\mathrm{w}$ „hurtownię wiedzy” ${ }^{17}$. Zmaganie się $z$ tym wzrastajacym $z$ różnych powodów zagrożeniem to jedno $z$ wielu poważnych i trudnych

szałek, Toruń 2011 (zwłaszcza rozważania Lecha Witkowskiego dotyczące niepożądanych aspektów reformy szkolnictwa wyższego, która okazuje się dalece destrukcyjna dla humanistycznie pojętego uniwersytetu). Zob. też: A. Walicki, Niebezpieczne nieporozumienia $w$ sprawach nauki, „Przegląd” z 20 stycznia 2011 r., s. 46-49; M. Czerepaniak-Walczak, Uniwersytet - instytucja naukowo-edukacyjna czy przedsiębiorstwo? Szkoła wyższa $w$ procesie zmiany, w: Innowacje w edukacji akademickiej..., s. 53-64; M. Dudzikowa, Niekomfortowe położenie instytucji uniwersytetu $w$ kłopotliwym kontekście. Esej w trosce o rozwój (nie tylko) kapitału społecznego, w: M. Dudzikowa, R. Wawrzyniak-Beszterda, S. Jaskulska, M. Marciniak, E. Bochno, I. Bochno i K. Knasiecka-Falbierska, Oblicza kapitału społecznego uniwersytetu. Diagnoza - interpretacje - konteksty, Impuls, Kraków 2013, s. 257-378; T. Bauman, Uniwersytet jako balast dla ideologii rynkowej, w: Pytanie o szkołe wyższa. W trosce o człowieczeństwo, red. B.D. Gołębniak, Wyd. Dolnośląskiej Szkoły Wyższej, Wrocław 2008, s. 116-131; E. Potulicka, Uniwersytet na „wolnym rynku”, w: Neoliberalne uwikłania edukacji, red. E. Potulicka, J. Rutkowiak, Impuls, Kraków 2010, s. 281-295; Wiedza, ideologia, władza. O społecznej funkcji uniwersytetu $w$ społeczeństwie rynkowym, red. P. Żuk, Scholar, Warszawa 2012; I. Białecki, Etos i polityka jakości w nauce, „Nauka i Szkolnictwo Wyższe" 2014, nr 1-2 (43-44), s. 19-29; D. Antonowicz, O nieoczekiwanych konsekwencjach procesu ekspansji szkolnictwa wyższego w Polsce, „Nauka” 2015, nr 4, s. 145-159.

15 Por. G. Ritzer, Makdonaldyzacja społeczeństwa. Wydanie na nowy wiek, tłum. L. Stawowy, Muza, Warszawa 2005. Sens pojęcia „makdonaldyzacja” Ritzer wyjaśnia: „to proces, na mocy którego zasady prowadzenia restauracji szybkiej obsługi upowszechniaja się, zagarniając coraz większe połacie życia społecznego w Stanach Zjednoczonych i na całym świecie" (wstęp).

${ }^{16}$ M.S. Szczepański, McDonald’s na uniwersytecie, „Tygodnik Powszechny” 2001, nr 3; idem, McDonald's $w$ uniwersytecie, „Nauka” 2002, nr 1, s. 155-161.

${ }^{17}$ R. Nowakowska-Siuta, Uczelnia czy hurtownia wiedzy?, „Przegląd Powszechny” 2010, nr 10, s. 47-63. Zbigniew Kwieciński zwracał uwagę na niektóre destrukcyjne skutki wprowadzania tzw. rozwiązań bolońskich: „Przełamanie kształcenia akademickiego na trzyletnie "studia" zawodowe i dwuletnie "studia" drugiego stopnia doprowadziło de facto do samobójstwa uniwersytetów, co samo w sobie jest problemem wartym zbadania i zrozumienia, choć nie usprawiedliwienia. Inteligencja różnych nurtów specjalistycznych nie może mieć rzetelnego fundamentu wprowadzenia do kultury". Z. Kwieciński, Edukacja - trudne pytania. Początek działalności Komitetu Rozwoju Edukacji Narodowej PAN, „Nauka” 2013, nr 1 , s. 10. 
wyzwań, przed którymi znajduje się społeczność akademicka uznająca ideę uniwersytetu i jego autonomię za cenną wartość.

Uniwersytet w kulturze zachodniej już od dłuższego czasu znajduje się na wirażu. Gdy na początku roku akademickiego 2002/2003 czytałem - i polecałem na zajecciach studentom - listopadowy numer czasopisma „Nowa Res Publica” (2002 nr 11), którego przewodni temat brzmiał: „Uniwersytet w ruinie. Uniwersytet marzeń”, to w tekście Jerzego Axera Glosy do ksiażki Billa Readingsa The University in Ruins uwage przykuło budzace wówczas niepokój - i jak się po kilkunastu latach okazuje, bardzo trafne - stwierdzenie: „Uniwersytety w Polsce przeżywaja trudności będace wynikiem transformacji ustrojowej. Prawdziwe kłopoty czekaja nas jednak dopiero potem. Lepiej przeczytać książkę Readingsa wcześniej niż później”18. Choć wielu czytelników tej przenikliwej uwagi mogło - dość naiwnie - łudzić się, że na nadejście tych skądinąd znanych kłopotów polskie uniwersytety odpowiednio się przygotują. Promotor idei artes liberales na gruncie polskim ${ }^{19}$, którym jest Axer, dysponujac szerokim oglądem światowych doświadczeń, przestrzegał tych, którzy grzeszyli naiwnością, że
nawet jeśli poprawa sytuacji ekonomicznej przyniesie podwyżkę pensji oraz umożliwi lepsze wyposażenie bibliotek i laboratoriów, to w niczym nie poprawi się sytuacja humanisty, który myśli o sensie i godności własnej pracy. To właśnie lata 80. i 90. ubiegłego wieku przyniosły prawdziwie antyintelektualny przełom [...] wtedy, w okresie boomu ekonomicznego, profesorowie zostali zepchnięci na margines świado- mości społecznej ${ }^{20}$.

Owszem, niektórzy spośród profesorów - zauważa Axer - ratowali się przed marginalizacją ich oddziaływania zaangażowaniem w aktywność polityczna, ale - jeśli idzie o istotne dla humanistyki wartości intelektualne - był to tylko pozorny i wręcz na dłuższa metę przeciwskuteczny spo-

18 J. Axer, Glosy do książki Billa Readingsa The University in Ruins, „Nowa Res Publica" 2002, nr 11, s. 41.

19 W 2002 r. prof. Axer kierował pracami działającego od 1991 r. Ośrodka Badań nad Tradycją Antyczna w Polsce i Europie Środkowo-Wschodniej Uniwersytetu Warszawskiego, który w 2008 r. przekształcono w Instytut Badań Interdyscyplinarnych „Artes Liberales”, a obecnie w Wydział „Artes Liberales” UW.

20 J. Axer, Glosy do książki..., s. 41. 
sób zapobieżenia zepchnięciu na margines. Czyli mimo podjętych prób, a nawet również $z$ ich powodu profesorowie uniwersyteccy nie uniknęli swego - rzec można - cywilizacyjnego przeznaczenia, wyrzuciło ich „na wirażu" na margines życia społecznego.

Jak więc powinien zmieniać się uniwersytet, zwłaszcza polski uniwersytet, aby uniknąć marginalizacji? Rozsądną i zarazem powściagliwą w zapędach reformatorskich receptę zaproponował Roman Galar w ramach debaty (5-6 grudnia 1996 r.) dotyczącej idei uniwersytetu u schyłku tysiąclecia, zorganizowanej przez Fundację na rzecz Nauki Polskiej:

\begin{abstract}
Jak sądzę, zalety naszego systemu kryją się paradoksalnie w jego „ewidentnych uchybieniach”. Wciąż jeszcze istniejace enklawy organizacyjnego chaosu, szczeliny kompetencyjnego niedopasowania, epizody profesorskiej samowoli i fajerwerki improwizacji układają się w „ścieżkę zdrowia", na której żywa inteligencja studentów może trenować działania w warunkach niepełnej informacji, dostosowanie do nieoczekiwanych zmian sytuacji, odporność na niesprawiedliwe porażki i sceptycyzm wobec oficjalnych autorytetów. Zlikwidujemy ten poligon adaptacyjny, a stworzymy warunki dla tuczu miernot ${ }^{21}$.
\end{abstract}

Dla zwolenników konstruowania - wedle administracyjnych reguł „doskonałości” - nowego ładu wyzbytego z życiodajnego chaosu i „fajerwerków improwizacji" te słowa, w których eksponuje się elementarna ludzką rozumność jako podstawę wszelkiego rozwoju, mogą brzmieć dość obrazoburczo, jako wręcz ekstrawagancja humanisty snującego anarchizujacca wizję nauki i nauczania, choć ich autor - profesor politechniki i inżynier - jest przedstawicielem nauk ścisłych i technicznych. Co więcej, ich autor w pełni świadomie przeciwstawia się coraz mocniej zarysowującym się wówczas tendencjom, które

zgodne sa $z$ industrialnym pojmowaniem rzeczywistości i - gdyby rzeczywistość miała charakterystykę taśmy produkcyjnej $-z$ pewnościa przyniosłyby wiele dobrego. [...] Sa to koncepcje racjonalne w świecie pragmatyki służbowej: stopni naukowych, rozliczeń finansowych, wydajności kształcenia, wskaźników naukometrycznych itp. ${ }^{22}$

${ }^{21}$ R. Galar, Uniwersytet jako narzędzie adaptacji cywilizacyjnych, w: Idea uniwersytetu u schyłku tysiaclecia, red. H. Samsonowicz, J. Sławiński, L. Szczucki, Fundacja na rzecz Nauki Polskiej, Warszawa 1998, s. 129.

22 Ibidem. 
Idea naczelną tych „rozwiązań jest doskonały porządek jako wartość sama w sobie”23, a przecież ów „doskonały porządek”, właściwy niektórym modelom świata idealnego, nie jest natomiast cecha ludzkiej, dynamicznej rzeczywistości oraz nie jest także pożądany jako dominująca - urzeczywistniana na siłę - cecha nauki i nauczania akademickiego.

Dyskusja o uniwersytecie, który obraca się w ruinę, również z powodu nietrafnych reform, i o Uniwersytecie marzeń, który pisze się przez wielkie „U”, odbywała się też - jako temat wiodący - na łamach innych czasopism kulturalno-społecznych, a przyjmowane wiodace tytuły oddawały i współtworzyły klimat tej debaty. W milenijnym, 2000 roku ukazał się lutowy numer miesięcznika „Znak”, który zatytułowano Uniwersytet przed reanimacja, tym samym sygnalizując, że nastapiła lub dalej następuje jakiegoś rodzaju zapaść polskich uniwersytetów i polskiej nauki. Dużymi literami na okładce miesięcznik „Odra” (2002, nr 11) na pierwszym miejscu wyróżnił tytuł: UNIWERSYTET W ZBÓJECKICH CZASACH, eksponując aktualność i doniosłość problematyki podjętej przez Jerzego Brzezińskiego w tak też zatytułowanym tekście ${ }^{24}$. W 2002 roku opublikowano „Pressje. Teka pierwsza Klubu Jagiellońskiego” (zima 2002 r.) majace na okładce prowokacyjnie sformułowany temat wiodacy: „Dlaczego w Polsce nie ma Uniwersytetu”. W zamieszczonych tekstach przeważało poszukiwanie wizji takiego Uniwersytetu, która uznawano za optymalna, i nie tracono wiary w możliwość jej urzeczywistnienia; choć poważnie zastanawiano się nad szansami na realizacje proponowanej wizji, gdyż podane informacje o tym, co się dzieje ze szkolnictwem wyższym w innych krajach, m.in. o wzrastającej biurokratyzacji, wcale nie napawały optymizmem. Ważnym głosem i punktem odniesienia w toczacej się wówczas debacie była - dostępna już w języku polskim i omawiana w środowiskach akademickich - książka Umysł zamknięty. O tym, jak amerykańskie szkolnictwo wyższe zawiodło demokracje $i$ zubożyło dusze dzisiejszych studentow (The Closing of the American Mind. How Higher Education Has Failed Democracy and Impoverished the Souls of Today's

23 Ibidem.

${ }^{24}$ J. Brzeziński, Uniwersytet $w$ zbójeckich czasach, „Odra” 2002, nr 11, s. 2-7. Zob. idem, O formacyjnej roli uniwersytetu, „Czasopismo Psychologiczne” 2010, nr 16 (1), s. 151155; idem, Etos akademicki - między tradycja i wyzwaniami współczesności, „Teksty Drugie” 2010, nr 5, s. 227-235. 
Students, New York 1987) ${ }^{25}$. Jej autor, Allan Bloom (1930-1992), krytykował niekorzystna dla realizowania zasadniczej misji uniwersytetów presję ideologiczną i bronił klasycznej wersji ich funkcjonowania. Gdy na polskim gruncie czytano i dyskutowano, ,jak amerykańskie szkolnictwo wyższe zawiodło demokrację i zubożyło dusze dzisiejszych studentów", to zazwyczaj żywiono - jak się okazuje dość złudna - nadzieję, że wiedza o amerykańskich doświadczeniach i niepowodzeniach stwarza dogodna sytuację i daje szansę, iż uniknie się głównych błędów prowadzących do urabiania „zamkniętego umysłu”, a tym bardziej że nie będą one świadomie generowane moca urzędowych rozporządzeń. $Z$ dzisiejszej perspektywy ówczesne myślenie, życzeniowe myślenie, iż dzięki akademickiej autonomii skutecznie przezwycięży się mniej lub bardziej dolegliwe słabości, a zarazem zachowa się i wzmocni walory polskiego uniwersytetu, może być poczytane za przejaw naiwności.

Realistyczna okazała się prognoza Axera, który głosił, że prawdziwe kłopoty dopiero na nas czekaja. Aby się z nimi należycie zmierzyć, trzeba m.in. podjać odpowiednio ukierunkowane badania. Zintegrowana i systematyczna formułę badań nad przemianami uniwersytetu w tekście Zmierzch nowoczesnego uniwersytetu zarysował w 2000 roku Marek Kwiek $^{26}$ :

przyszłość instytucji uniwersytetu warto badać z perspektywy projektu kulturowego, który ją zrodził: projektu nowoczesności, ponieważ poza kontekstem zmierzchu tego projektu, w epoce późnej nowoczesności i w erze globalizacji, coraz trudniej filozoficznie wykładać sens przypuszczalnego przechodzenia do nowej formy uniwersytetu. Jest to zmiana kulturowa o niezwykłej wadze, bowiem dotyczy dzisiejszego

${ }^{25}$ A. Bloom, Umysł zamknięty. O tym, jak amerykańskie szkolnictwo wyższe zawiodło demokracje $i$ zubożyło dusze dzisiejszych studentów, thum. T. Biedroń, Zyski S-ka, Poznań 1997. Zob. też: Universities in Crisis, Blog of the International Sociological Association (ISA), http://www.isa-sociology.org/universities-in-crisis/ (10.10.2015).

${ }^{26}$ Nota biograficzna podaje m.in. informacje o kierunkach badań, które podejmuje obecnie M. Kwiek: od 2000 r. prowadzi rozległe, interdyscyplinarne, międzynarodowe badania porównawcze instytucji uniwersytetu w Europie (w ramach ok. 20 międzynarodowych projektów badawczych i ok. 20 międzynarodowych projektów z dziedziny polityki publicznej). Międzynarodowy doradca i ekspert w sprawach polityki edukacyjnej i polityki naukowej. Założyciel i redaktor serii wydawniczej Higher Education Research and Policy (HERP) w Peter Lang International Academic Publishers. Od 2002 r. dyrektor Centrum Studiów nad Polityką Publiczna, od 2012 r. kierownik Katedry UNESCO Badań Instytucjonalnych i Polityki Szkolnictwa Wyższego. 
i przyszłego funkcjonowania, finansowania, wolności, celów, zadań, zobowiąań i roli uniwersytetu. W okresie przełomu, jeżeli nie akceptuje się tak jawnych w krajach anglosaskich społecznych skutków procesów „korporatyzacji” czy „menedżeryzacji” uniwersytetu, potrzebne jest jego syntetyczne i transdyscyplinarne ujęcie ${ }^{27}$.

Dalej przybliżał przyjęta perspektywę badań:

Kiedy zdamy sobie sprawę $z$ tego, że chodzi dzisiaj [...] nie tylko o zwykła (finansowa) „reorganizację” czy „restrukturyzację” szkolnictwa wyższego, lecz o bardziej ogólną kwestię zmierzchu kulturowego projektu nowoczesności, którego część stanowił i stanowi uniwersytet [...], dyskusja na temat przyszłości uniwersytetu [...] [będzie] bardziej fundamentalna. Kryzys tożsamości [...] jest nieodłączny od szerokiego przejścia zarówno w kulturze (od nowoczesności do późnej nowoczesności czy ponowoczesności), jak i w ekonomii i polityce (w obliczu globalizacji) ${ }^{28}$.

W refleksji prowadzonej przez Kwieka sa zawarte też takie sformułowania, które moga być odczytane jak zapalenie się czerwonego światła, które ostrzega przed niepożądanymi - w szczególności z punktu widzenia humanistów - zmianami:

Uniwersytet, który przyjmie grę w ramach pytań stawianych przez logikę ekonomii, stanie się $z$ czasem przedsiębiorstwem (i nie znajdzie już pocieszenia $\mathrm{w}$ fakcie, że będzie to przedsiębiorstwo edukacyjne). [...] zostanie mu przydzielone [...] miejsce przedsiębiorstwa edukacyjnego, które ma szybko, tanio i wydajnie szkolić specjalistów. Najlepiej [...] bardzo szybko, bardzo tanio i bardzo wydajnie ${ }^{29}$.

Nadmienić należy, że Kwiek konsekwentnie rozwija zarysowany w 2000 roku program badań - w ramach higher education research nad zmianami w funkcjonowaniu uniwersytetu, co m.in. znalazło wyraz w jego autorskich monografiach Uniwersytet $w$ dobie przemian. Europejska perspektywa porównawcza (Warszawa 2015) i Transformacje uniwersytetu. Zmiany instytucjonalne $i$ ewolucje polityki edukacyjnej $w$ Europie (Poznań 2010). Zawierają one - obok głównego wątku analiz eksperckich

27 M. Kwiek, Zmierzch nowoczesnego uniwersytetu, „Forum Akademickie” 2000, nr 1, http: / / forumakad.pl/archiwum/2000/01/artykuly/08-agora.htm (10.10.2015).

28 Ibidem.

29 Ibidem. Zob. M. Kwiek, Uniwersytety, produkcja wiedzy i konkurencyjność gospodarcza w Europie Środkowej, „Nauka i Szkolnictwo Wyższe” 2014, nr 1-2 (43-44), s. 91-116. 
- także takie spostrzeżenia, które - choć sa sformułowane w trybie sprawozdawczym - moga być odbierane jako sygnał, że oficjalna polityka Unii Europejskiej już całkowicie - $\mathrm{i}$ to $\mathrm{z}$ rozmysłem - odchodzi od klasycznej idei uniwersyteckości:

Publiczny uniwersytet w Europie jest coraz częściej uważany jedynie za część sektora publicznego, a jego tradycyjne roszczenia do społecznej (a tym samym również ekonomicznej i politycznej) wyjątkowości sa coraz częściej i coraz bardziej otwarcie kwestionowane ${ }^{30}$.

Nie tyle dyskutuje się o uniwersytecie, dopuszczając do głosu różne stanowiska, ile akcentuje się i promuje - negatywnie nastawiona - krytykę: „Uniwersytet europejski jako instytucja jest w zasadzie krytykowany we wszystkich swoich aspektach aż po same historyczne fundamenty"31. Jeśli tak faktycznie się dzieje, to tym bardziej - dla zachowania pluralizmu stanowisk - należy wciąż na nowo, w zmieniającym się kontekście podejmować refleksję nad klasycznym modelem i etosem uniwersyteckości, aby obraz uniwersytetu nie był znany jedynie $z$ tego, jak jest ukazywany w zwierciadle negujacej jego sens krytyki.

Przedstawiając dalsze dociekania jako przyczynek do toczącej się debaty, kieruję się słusznym wskazaniem Michała Hellera:

Będę pisał o uniwersytecie, edukacji, pracy naukowej. Obiecuję, że nie wspomnę ani słowem o pieniądzach. Pieniądze maja jednak coś wspól-

${ }^{30}$ M. Kwiek, Transformacje uniwersytetu. Zmiany instytucjonalne i ewolucje polityki edukacyjnej w Europie, Wyd. UAM, Poznań 2010, s. 333. Zob. M. Ziółkowski, O pewnych konsekwencjach częściowego i niekonsekwentnego utowarowienia polskiego szkolnictwa wyższego, „Nauka” 2005, nr 2, s. 29-44; A.K. Wróblewski, Misja uniwersytetów: poszukiwanie prawdy czy pogoń za zyskiem?, „Nauka” 2011, nr 3, s. 51-59. Przykład opinii w czasie ostatnio tocznych debat o przyszłości szkolnictwa wyższego i nauki w Polsce: K. Mikołajczyk, K. Pawlaczyk, Jakie maja być nasze uczelnie i polska nauka? - relacja z debaty o przyszłości szkolnictwa wyższego i nauki w Polsce, „e-Mentor” 2015, nr 3 (60), s. 4-6. Obecny stan debaty referuje i analizuje M. Kwiek, Przyszłość uniwersytetów $w$ Europie: motywy dyskusji i ich polskie konteksty, „Nauka i Szkolnictwo Wyższe” 2014, nr 1-2(43-44), s. $71-89$.

${ }^{31}$ M. Kwiek, Transformacje uniwersytetu..., s. 334. Zob. J.J. Jadacki, Etos Akademii: Sokrates czy sukces, w: Europa wspólnych wartości. Chrześcijańskie inspiracje $w$ budowaniu zjednoczonej Europy. Materiały II Kongresu Kultury Chrześcijańskiej, red. S. Zięba, Wyd. KUL, Lublin 2004, s. 269-271; M. Czerepaniak-Walczak, Homo academicus $w$ świecie homo oeconomicus. O obszarach i przejawach zmagań $z$ akademickim zniewoleniem, „Pedagogika Szkoły Wyższej” 2014, nr 1, s. 11-24; J. Świrko-Pilipczuk, Homo Oeconomicus as the Foundation of Educational Practices, „Opuscula Sociologica” 2015, nr 1, s. 49-57. 
nego $z$ ideami - jedne i drugie moga ulec dewaluacji. Ale jest między nimi zasadnicza różnica: jeżeli pieniądze ulegną dewaluacji, jakaś dobra idea może je wyprowadzić z finansowego kryzysu. Ale jeżeli zdewaluują się idee, nie pomogą żadne pieniądze ${ }^{32}$.

Gdy częstokroć $z$ wielką mocą akcentuje się finansowe aspekty funkcjonowania uniwersytetów, to jakby zapomina się przy tym, że finanse to nie jest siła samoczynna; ale być może - nie całkiem świadomie - wyznaje się wiarę w kreatywną i sprawcza moc pieniądza jako pierwszej przyczyny, jako metafizycznego poruszyciel wszelkiej aktywności. Taka wiara wszakże zaślepia na swoiste wartości uniwersytetu.

\section{Klasyczny etos uniwersytetu a nowe zagrożenia dla uniwersyteckiej wolności}

W klasycznie pojętej kulturze europejskiej uznaje się swoistą tożsamość uniwersytetu i jego nieredukowalność do innych - nawet do bliskich mu - form kulturowych. Uniwersytety mają w szczególny sposób urzeczywistniać etos pracy intelektualnej i manifestować wartości poznawcze, którym ma służyć uprawianie nauki i system edukacji. Uniwersytet spośród innych form kształtowania kultury intelektualnej wyróżniać się powinien zwłaszcza dążeniem do całościowego poznania rzeczywistości, a co najmniej do zespolenia we względna całość aspektowego poznania rzeczywistości. Takie dążenie motywuje przekonanie, że jedności rzeczywistości powinna odpowiadać jedność wiedzy o niej. Jak przypomina Tadeusz Czeżowski (1889-1981) ${ }^{33}$ : „Uniwersalność jest zasada, wyrażająca się już w nazwie uniwersytetów [...]. Wyraża się w tej zasadzie okoliczność, że

\footnotetext{
${ }^{32}$ M. Heller, Śmierć uniwersytetów, „Tygodnik Powszechny” 2012, nr 28, http://tischner. $\mathrm{pl} /$ aktualnosc/603/1/ks-michal-heller-o-smierci-uniwersytetow (10.10.2015). Ten interesujący i ważny tekst prof. Michała Hellera spotkał się m.in. z oficjalna polemika ze strony urzędującej wówczas minister, która podejmując dyskusję, zachowała się tak, jakby żywiła przekonanie, iż z tej racji, że sprawuje administracyjna władzę nad - skądinąd autonomicznymi - uniwersytetami, to dzięki władzy ma zarazem odpowiednią i wyczerpująca wiedzę (a idąc dalej, to poczuwa się do służbowego obowiazku wyjaśnienia prof. Hellerowi, jaki jest prawdziwy stan uniwersytetu, bowiem właściwy ogląd sytuacji ma umożliwiać jedynie zasiadanie w ministerialnym fotelu...).
}

${ }^{33}$ Zob. D. Lukasiewicz, Filozofia Tadeusza Czeżowskiego, Wyd. Akademii Bydgoskiej im. Kazimierza Wielkiego, Bydgoszcz 2002. 
wszystkie nauki pozostają ze soba w wielorakich zwiazkach"34. I co więcej, zakres tej uniwersalności pojmuje dość maksymalistycznie i rozciaga też na wypracowanie spójnego poglądu na świat: „Wszystkie bowiem dążą do zbudowania jednolitego na świat poglądu i wzajemnie wspieraja się w tym dążeniu" 35 . Uniwersytet to także universitas magistrum et scholariumwspólnota mistrzów i studentów, czyli wspólnota osób odpowiedzialnych za udzielanie i pobieranie nauk.

Współczesny stan rozchwiania samych podstaw uniwersytetu i negowania głównych idei uniwersyteckości wyraźnie kontrastuje ze wspomnieniem o życiu dawnego uniwersytetu, którym dzieli się Karl Jaspers (1883-1969) studiujacy na początku XX wieku:

Wobec nauczycieli wybitnych żywiłem głęboką cześć, respekt wobec tych, których nie aprobowałem. Gmach, aulę, tradycyjne uniwersyteckie obrzędy: do tych rzeczy odnosiłem się z pietyzmem. Nie wiedziałem dokładnie, co nadaje temu blask, wówczas jeszcze widzialny ${ }^{36}$.

Czyli wspólnota mistrzów i studentów jawi się jako wspólnota mająca także wymiar swoiście estetyczny ${ }^{37}$. Warto zastanowić się, na czym polega wspominany przez Jaspersa szlachetny blask uniwersytetu. Dlaczego dziś go nie widać? Jakie niepożądane praktyki go przesłoniły? Jak można ten swoisty blask uniwersyteckich wartości odzyskać, uczynić na nowo widzialnym w obecnej sytuacji? Na trop jednej z dość prawdopodobnych odpowiedzi naprowadza Jacek Piekarski, gdy dociekajac, na czym polega i w jakich postaciach występuje estetyczny wymiar kształcenia akademickiego, dochodzi do stwierdzenia:

Uczestnictwo w tworzeniu wiedzy posiada rzeczywistą ważność, gdy odwołuje się do najgłębszego zaangażowania, gdy ukierunkowane jest na poszukiwanie i odkrywanie możliwie najdonioślejszego, indywidual-

${ }^{34}$ T. Czeżowski, O uniwersytecie $i$ studiach uniwersyteckich, Księgarnia Naukowa T. Szczesny, Toruń 1946, s. 8.

35 Ibidem.

${ }^{36}$ K. Jaspers, Autobiografia, tłum. S. Tyrowicz, Comer, Toruń 1993, s. 55.

37 Zob. J. Piekarski, Estetyzacja praktyki akademickiej-głos $w$ dyskusji na temat perspektywy uczestniczacej, w: Innowacje w edukacji akademickiej..., s. 235-251. 
nego sensu. Temu właśnie sensowi zawsze wypada nadawać możliwe najdoskonalszy wyraz ${ }^{38}$.

Ów estetycznie pociagający, wzniosły blask uniwersytetu zdaja się w dużej mierze wytwarzać perfekcjonistyczne intencje i osobiste (osobowe) zaangażowanie w uczestnictwo w działaniach wiedzotwórczych, a zwłaszcza ich ukierunkowanie na urzeczywistnianie tego, co w wymiarze epistemicznym i etycznym będzie docelowo możliwie doskonałe.

Częstokroć eksponowanie tradycyjnych walorów uniwersytetu dopełnia się - w jednej wypowiedzi - niepokojem, czy te walory nie sa w zaniku. Wyraził to m.in. Jan Paweł II: „Instytucja uniwersytetu jest jednym $z$ arcydzieł ludzkiej kultury. Zachodzi tylko obawa, czy to arcydzieło nie ulega w dzisiejszej epoce odkształceniu, i to w wymiarze globu" (6 czerwca 1979 r.). Gdy współcześnie, z punktu widzenia tzw. polityki naukowej czy edukacyjnej lub z punktu widzenia „zarządzania nauka i produktywnościa naukowa”, rozpatruje się społeczne funkcje uniwersytetu, to głównie zwraca się uwagę na jego efektywność wedle wzorców wydajności produkcyjnej i zysku ekonomicznego. Prowadzi się obecnie wzmożona kontrolę działań naukowo-dydaktycznych uniwersytetu, którą wyraża się wszakże w języku obcym - a nawet wrogim - etosowi i wartościom klasycznie pojętego uniwersytetu.

Jeśli odwołać się do opinii panującej wśród części społeczności akademickiej, opinii znajdującej też swój wyraz w literaturze przedmiotu, to $\mathrm{w}$ duchu krytycznej refleksji da się $\mathrm{w}$ przybliżeniu przedstawić taki oto szkic do obrazu postępujacej obecnie destrukcji klasycznie pojętego etosu uniwersyteckiego: biurokratyczne nadregulacje systemowe wprowadzane w środowiska i struktury uniwersyteckie żłobią i utrwalaja koleiny paraliżującej małostkowości, gdyż wymuszaja - usilnie ponawiane - próby ilościowego zaksięgowania nieprzeliczalnych przecież walorów wyników aktywności intelektualnej. Niszczy się w ten sposób autonomię i uniwersyteckość klasycznie pojętego uniwersytetu i narzuca na uniwersytet taki system, który da się określić jako formę koszarowej dyscypliny. Wedle biurokratycznych i bezdusznych dyrektyw promuje się działania destrukcyjne dla kształtowania przez autonomiczny uniwersytet kultu-

${ }^{38}$ Ibidem, s. 250. 
ry intelektualnej i duchowej ${ }^{39}$. Bałamutne ideologie technokracji na siłę (moca arbitralnych dekretów) wprowadzane są w autonomicznej sferze akademii i zespolonej z nią wolności intelektualnej. Regulacje przyrastaja i obrastaja kolejnymi uszczegóławiającymi regulacjami w uniemożliwiającym ich recepcję tempie, a w praktyce wypełnia się tony zbędnych papierów i ogłupiających tabelek, z których nie ma ani intelektualnej, ani duchowej korzyści, a następuje tylko zaśmiecanie przestrzeni uniwersytetu i niszczenie akademickiej wolności. Powstała jakby grupa wyznawców domniemanej sanacji i „uzdrowicielskiej mocy” tych regulacji, co jawi się wręcz jako bałwochwalstwo okazywane administracyjno-biurokratycznej potędze, a zarazem - co gorsza - jest to mocne i mające praktyczne skutki wyznanie niewiary w indywidualne ludzkie sumienie, także wyznanie niewiary w moc sumienia w zakresie aktywności intelektualnej i dydaktycznej. Taka wizja społecznego funkcjonowania instytucjonalnej nauki i dydaktyki uniwersyteckiej okazuje się wręcz zabójcza dla uniwersyteckiego etosu ${ }^{40}$.

${ }^{39}$ Zob. J. Mizińska, Bezduszny uniwersytet, Fundacja Homo Inquitus (2010), http:// www.homoinquietus.org/ (10.10.2015). Jadwiga Mizińska ukazuje obraz dyktatury procedur generujących banalność i kształtujących „ludzi banalnych”: „Cała uniwersytecka machina działa obecnie w jednym kierunku: aby nagradzać bezkrytyczne posłuszeństwo kolejnym zarzadzeniom ministerstwa, rektora i pomniejszych władz. Prowadzi to nieuchronnie do wspomnianej banalizacji i prymitywizacji myśli, postaw oraz stylu bycia, który zawsze dotąd stanowił wyróżnik Ludzi Uniwersytetu. Odgórne instytucje (w rodzaju ministerstwa i wszelakich ministerialnych komisji) powołuja się, jako na w gruncie rzeczy jedyny argument, na produkowane przez siebie lawinowo PROCEDURY. To tajemnicze słowo ( $\mathrm{z}$ czasownikowa odmiana „procesowanie”) ma moc obezwładniająca. Zamyka wszelka dyskusję, a raczej w ogóle do niej nie dopuszcza. Banalność to, w dużej mierze, nieunikniony (i chyba zamierzony) skutek Dyktatury Procedur” (ibidem, pkt 6. „Uniwersytet jako producent Ludzi Banalnych").

${ }^{40}$ Zob. M. Czerepaniak-Walczak, Autonomia $w$ kolorze sepii $w$ inkrustowanej ramie KRR. O procedurach i treściach zmiany w edukacji akademickiej, w: Fabryki dyplomów czy universitas? O „nadwiślańskiej” wersji przemian w edukacji akademickiej, red. M. Czerepaniak-Walczak, Impuls, Kraków 2013, s. 29-56. O polskim wdrażaniu KRK: „Działania przepełnione pozorem, zaburzające dotychczasowe tradycje akademickie, wbrew obietnicy wzrostu autonomii i wdrożenia do uczenia się przez całe życie, w istocie wnosza do edukacji uniwersyteckiej sformalizowany system nadzoru. Uniwersytet rezygnuje $z$ autonomii, a nawet wyrzeka się jej na rzecz zapewnienia sobie bezpieczeństwa. Podporządkowuje się grom rynkowym oraz doraźnym oczekiwaniom studentów i potencjalnych pracodawców. Pragnę podkreślić, że nie kwestionuję idei KRK jako narzędzia poprawy jakości edukacji akademickiej, tworzenia warunków mobilności społecznej oraz utrwalania potrzeby uczenia się przez całe życie, ale podaję w watpliwość sposób wdrażania zasad KRK do uczelnianej praktyki. Wspomniany dokument wskazuje bowiem na traktowanie uniwersytetu jako urzadzenia edukacyjnego". Eadem, Wprowadzenie, w: Fabryki dyplomów..., s. 17. 
W tym kontekście trzeba przypomnieć, że John Henry Newman (1801-1890) w klasycznym dziś dziele Idea Uniwersytetu - pochodzacym z połowy XIX wieku - stwierdza: „bez wahania dałbym pierwszeństwo temu Uniwersytetowi, który nic nie robi, nad tym, który by wymagał od swych adeptów zapoznawania się $z$ wszelkimi naukami pod słońcem"41. Owo „uniwersyteckie nic-nie-robienie” jako szczególnego rodzaju forma działalności wewnątrz uniwersytetu owocuje wszakże w długodystansowej perspektywie, a taka perspektywę zapewnia cechujace się „długim trwaniem” istnienie uniwersytetu. Jeśli nie chce się respektować swoistego „uniwersyteckiego nic-nie-robienia”, narzucajacc i egzekwując wymogi uzyskiwanie szybkich i widocznych - również medialnie nośnych efektów, to niszczy się wewnątrzuniwersytecki upływ czasu, odmawia się prawa do wypracowania dojrzałej refleksji, która wymaga swego czasu, aby mogła we własnym rytmie dojrzewać. Zamiast prawa do „nic-nie-robienia” wprowadza się przede wszystkim grę pozorów i iluzji, promuje się niedojrzałość, a na dalszą metę niszczy się rozwój nauki i radykalnie zaniża poziom studiowania.

Studiowanie wymaga swoistej ascezy, rezygnacji $z$ osiagania pewnego typu wartości po to, aby móc dążyć do urzeczywistniania tych uniwersyteckich wartości, które uznaje się za cenne i unikatowe. Zwolennik upowszechniania oświecenia publicznego i rozwijania krytycznej, otwartej debaty, Karl R. Popper (1902-1994)42, zwraca uwage na niepokojące go zmiany w sytuacji uniwersytetów i w studiowaniu, a zwłaszcza na zanik niezbędnej dozy ascezy, zamiast której pojawia się podstawa roszczeniowa i konsumpcyjna rozbudzana i wspierana ideologia równych szans:

Idea równych szans i równego dostępu do wyższego wykształcenia w niektórych krajach doprowadziła do [...] żałosnych następstw. Dla mojego pokolenia walka o wiedzę była przygodą wymagająca wielkich ofiar, które zdobytej wiedzy nadawały jedyną w swoim rodzaju wartość. Obawiam się, że ta wartość zanikła. Nowe prawo do kształcenia wytworzyło postawę, która traktuje to prawo jako prawo zagwarantowane; a to, czego bez ofiar [ze swej strony] możemy żądać jako naszego prawa,

${ }^{41}$ J.H. Newman, Idea Uniwersytetu, tłum. J. Fijaś, „Znak” 1978, nr 6, s. 709.

${ }^{42}$ Zob. S. Thornton, Karl Popper, w: Stanford Encyclopedia of Philosophy, http://plato. stanford.edu/entries/popper/ (10.10.2015). 
jest mało cenione. Społeczeństwo, dając studentom prawo do kształcenia, zabrało im niepowtarzalne przeżycie ${ }^{43}$.

Doświadczenie wartości studiów i wartości pomnażania wiedzy jako swoiste doświadczenie aksjologiczne nie powinno być przytłumione sprowadzeniem prawa do studiowania do poziomu jednego $z$ uprawnień socjalnych. Inne jeszcze poważne niebezpieczeństwo dla funkcjonowania uniwersytetu (ujawniajace się już w okolicach 1968 r.) wskazuje Popper w kontekście coraz intensywniejszego rozwoju cywilizacji technicznej:

Potrzeba coraz więcej techników, a w związku $z$ tym coraz więcej doktorantów szkoli się jedynie w zakresie technik pomiaru, a nie mówi się im nawet, jakie bardziej fundamentalne problemy mają być rozwiazywane przy pomocy pomiarów, które wykonuja, przygotowując swe prace doktorskie ${ }^{44}$.

Rozpowszechnienie takiego rodzaju szkolenia, które zawęża i redukuje horyzonty poznawcze, Popper uznaje za niedopuszczalne i moralnie naganne „złamanie przysięgi ze strony nauczyciela akademickiego"45. Pracownik nauki powinien rzetelnie spełniać powierzone mu zadania, wśród których na pierwszym planie sytuuje się „wprowadzanie ucznia w tradycję i wyjaśnianie mu nowych wielkich problemów wyłaniających się dzięki rozwojowi wiedzy, które z kolei inspiruja i pobudzaja wszelki dalszy rozwój"46. Jeśli edukację w szkolnictwie wyższym sprowadza się do „szkolenia w zakresie technik pomiaru”, to tym samym zdecydowanie osłabia się i wygasza dynamikę pracy intelektualnej, a uniwersytet przestaje pełnić swe podstawowe funkcje.

$\mathrm{Na}$ zagrożenie jakości studiowania i rozwoju intelektualnego wynikające $z$ wprowadzanych w pierwszej połowie XX wieku obowiazkowych programów studiów, których wcześniej nie było, wskazuje Jaspers:

${ }^{43}$ K.R. Popper, W co wierzy Zachód?, w: idem, W poszukiwaniu lepszego świat. Wykłady $i$ rozprawy z trzydziestu lat, tłum. A. Malinowski, Książka i Wiedza, Warszawa 1997, s. 254.

${ }^{44}$ K.R. Popper, Odpowiedzialność moralna uczonego, w: K.R. Popper, Mit schematu pojęciowego. W obronie nauki i racjonalności, tłum. B. Chwedeńczuk, Książka i Wiedza, Warszawa 1997, s. 140.

${ }^{45}$ Ibidem.
${ }^{46}$ Ibidem. 
Sztuczne przewodniki, takie jak konspekty programowe, [obowiązkowe programy studiów], curricula i tym podobne techniczne zabiegi, które zmieniają wyższą uczelnię w szkołę średnią sprzeczne sa $z$ ideałem uniwersyteckim. [...] Wykłady i seminaria nieco „ponad głowa” studenta, pobudzające do wzmożonego wysiłku, to lepsza alternatywa niż osiagnąć pełne zrozumienie za cenę upraszczania ${ }^{47}$.

I kontynuując swój wywód dopowiada:

Uniwersytet zmienia się w szkołę średnią po to, by osiagnąć zadowalająca przeciętna ze statystyczną niezawodnością. To prowadzi uniwersytet do ruiny. Gdy studentowi nie pozwala się pracować, studiować tak, jak uważa za właściwe, dławi się życie umysłu. Życie umysłu to życiowa szansa pośród morza porażek i frustracji. [...] Atmosfera przyziemnego i nieinspirującego zdrowego rozsądku może oczywiście produkować zadowalajace opanowanie technik i dajacych się sprawdzić testami informacji o faktach, ale taka atmosfera dławi prawdziwe zrozumienie i ducha przygody badawczejes.

Dziś obowiązkowe i szczegółowo rozbudowane programy studiów sa niestety powszechne, a co gorsza - przyjmuje się je za niezbywalna, konieczna i jakby odwieczną oczywistość.

Dla współczesnych asystentów i adiunktów, od których wymaga się wypełniania kolejnych sylabusów i innych dokumentów KRK, a nawet dla części profesury, która już przywykła do wciąż rozbudowującej się biurokracji, zaskakująco - a nawet niewiarygodnie - może brzmieć jednoznaczny i z silnym przekonaniem prezentowany pogląd Czeżowskiego (wyrażony bez skrępowania w rozprawie opublikowanej w 1946 r.):

Gdy przeto dla szkoły średniej jest konieczny program, według którego podaje ona system wiadomości przeznaczonych dla tej szkoły, to dla nauki uniwersyteckiej program tego rodzaju staje się zbędny. Wolność nauczania jest przeto $\mathrm{w}$ pierwszym rzędzie wolnościa od sztywnego programu nauczania. Nauczyciel akademicki nie jest krępowany programem, ma swobodny wybór tych działów wiedzy, które zamierza przedstawić ${ }^{49}$. s. 748 .

${ }^{47}$ K. Jaspers, Praca badawcza, kształcenie, nauczanie, tłum. hm, „Znak” 1978, nr 6,

48 Ibidem, s. 749.

49 T. Czeżowski, O uniwersytecie $i$ studiach..., s. 11. 
Gdy dziś przytacza się ten dość stanowczo wyrażony pogląd, to zwolennicy sztywno zaprojektowanych programów nauczania (lub przetrenowani przez obecny reżim) nie potrafia pojąc tych istotnych warunków wolności uniwersyteckiej. Obecnie klarowna i prosta teza, że „uniwersytecka wolność nauczania jest w pierwszym rzędzie wolnością od sztywnego programu nauczania", budzi mocny opór i sprzeciw tych, którzy kreuja się - wspierani decyzjami politycznymi - na włodarzy uniwersyteckiej przestrzeni edukacyjnej, a sa to przecież - jak jasno uzmysławia to m.in. argumentacja Jaspersa i Czeżowskiego - samozwańczy włodarze, bez których regulacji i kontroli nauczanie mogło i może się obyć. Co więcej, problematyczna nie jest - jak się dziś częstokroć mniema - uniwersytecka wolność od sztywnego programu nauczania, której obecnie niektórzy nie sa w stanie sobie nawet wyobrazić, bo tak dogłębnie zostali skażeni brakiem wewnętrznej wolności, ale $-z$ punktu widzenia idei uniwersytetu - zasadnicze watpliwości budzi redukowanie i odbieranie naturalnej uniwersyteckiej wolności przez administracyjne narzucanie wymogów przedstawiania i realizowania sztywnego programu nauczania.

Kolejna mogącą budzić niepokój kwestia jest postulowanie czy wręcz narzucanie profesorom obowiązu bezpośredniego wychowywania studentów. Częstokroć, także w administracyjnych dokumentach, wprost stwierdza się, że nauczyciele akademiccy sa zobowiązani wychowywać studentów, czyli-jeśli odpowiednio rozumie się wychowanie jako szczególnego rodzaju relację międzyosobowa między wychowawca i powierzonym jego pieczy wychowankiem - mają oni podejmować działania pedagogiczne, które są niestosowne względem osób dorosłych, tzn. względem osób zdolnych do samowychowania ${ }^{50}$. Owszem, nauczyciel akademicki prowadzi różnego rodzaju działania formacyjne, uprawia dydaktykę wychowawczą, czyli rzetelnie kształcąc, zarazem kształtuje i wzmacnia pożądane

${ }^{50} \mathrm{O}$ znaczeniu i różnych sposobach rozumienia samowychowania zob. B. Śliwerski, Teoretyczne i empiryczne podstawy samowychowania, Impuls, Kraków 2010. O samodzielności i samowychowaniu w obszarze działan dydaktycznych zob. J. Parafiniuk-Soińska, Struktura i efekty samodzielnego studiowania, PWN, Warszawa-Poznań 1976; eadem, Samodzielne uczenie się $w$ procesie dydaktycznym, Wyd. US, Szczecin 1988. O pedagogicznym ujęciu antropologicznych koncepcji samodzielności zob. J. Świrko-Pilipczuk, Samo-dzielność $w$ filozoficznych pogladach $i$ koncepcjach człowieka. Implikacje pedagogiczne, Zapol, Szczecin 2011. 
postawy studenta, ale - jeśli chce się zachować właściwy i swoisty sens wychowania - nie należy tego określać zbiorczym mianem „wychowania”, tylko odpowiednio dookreślić zakres najbardziej wskazanych działań formacyjnych oraz ukazać wartości i cele nauczania akademickiego (jako też dydaktyki wychowawczej/wychowujacej). Skrótowe hasło „wychowywania studentów" zaciemnia tak właściwy i swoisty sens wychowania ${ }^{51}$, jak też czyni nieczytelnym właściwy i swoisty sens studiowania.

Na problematyczność postulatu „wychowywania studentów” wskazuje Hans-Georg Gadamer (1900-2002), wspominając, jak tuż po 1945 roku $z$ amerykańskiej inicjatywy miał wygłosić we Frankfurcie wykład o wychowaniu w uniwersytecie. Zaproponowany mu tytuł wykładu brzmiał: „Jak profesor niemiecki widzi swoje zadanie wychowawcze?”. Gadamer na tak postawiona kwestię - jak wspomina - odpowiedział

jednoznacznie: w ogóle nie widzi, albowiem [profesor] nie ma żadnych [takich] zadań. Za późno przychodzi. [...] Profesor, który widzi swoich studentów kilka godzin w ciagu tygodnia, [...], będzie coś znaczył jedynie dla swych najbliższych uczniów i współpracowników ${ }^{52}$.

Ta zwięzła i jasna odpowiedź Gadamera pozostaje wciąż w mocy, ale niestety nie jest to moc wiążąca dla tych, którzy dość dowolnie posługują się słowem „wychowanie”, rozciagajac jego zakres na różne sposoby działań formacyjnych, lub też przeszacowuja siłę sprawczą oddziaływania profesora w jego relacjach ze studentami.

Spóźnione wychowywanie studentów - wedle tych, którzy je otwarcie postuluja - ma w dużej mierze spełniać funkcje kompensacyjne, ma bowiem zaradzić niedojrzałości osób podejmujacych studia, ale te próby "wychowywania studentów” skazane sa na to, że przyniosa skutki odwrotne od deklarowanych, gdyż w punkcie wyjścia $z$ dorosłych robi się duże, wyrośnięte dzieci, tym samym ugruntowując i wzmacniając niedojrzałość. Dzieląc się spostrzeżeniami i przemyśleniami z wieloletniej pracy nauczyciela akademickiego, Mieczysław Porębski (1921-2012) zauważa, że dla właściwego przebiegu studiów nie jest najgroźniejsze niedouczenie

\footnotetext{
${ }^{51}$ O różnych sposobach rozumienia wychowania zob. B. Śliwerski, Pedagogika ogólna. Podstawowe prawidłowości, Impuls, Kraków 2012.

${ }^{52}$ H.-G. Gadamer, Moja droga do filozofii. Wspomnienia, tłum. J. Wilk, Wyd. UWr, Wroclaw 2000, s. 113.
} 
rozpoczynających studia, ale ich niedojrzałość. Wspominając i pozytywnie oceniając własne doświadczenia edukacyjne, Profesor Porębski podkreśla: „Moje gimnazjum dawało dojrzałość - gimnazjum kończyli dorośli ludzie. Świadectwo dojrzałości zobowiazywało, znaczyło, że od tej chwili sami już muszą wybierać dalej, sami decydować o sobie"53. Odnosząc się do obecnej sytuacji (koniec lat osiemdziesiątych XX wieku), Porębski dodaje:

\begin{abstract}
A teraz nam się każe studentów wychowywać, mówi się, że na uniwersytecie jest młodzież i że nie tylko należy ich uczyć, ale pilnować, dozorować, zaliczać. Na różne sposoby usiłuje się przekształcić uniwersytet w szkółkę, zalicza się te wykłady kursowe, zdaje się niezliczone egzaminy, które polegają na wkuciu jakiejś kolejnej cząstki materiału. No i ten terror terminów... ${ }^{54}$.
\end{abstract}

Uwidacznia się, iż patologiczne sytuacje będące konsekwencjami błędnych koncepcji uniwersytetu i studiów splataja się ze sobą: nakaz wychowywania i nadzorowania wraz $z$ terrorem terminów $w$ praktyce zamieniają uniwersytet w szkółkę nakładającą na niesfornych uczniów - i zarazem na profesorów jako nadzorców - kierat dyscypliny, który niweczy sens uniwersyteckiej wolności. Od czasu wypowiedzenia przez Porębskiego trafnych uwag o tym, jak na różne sposoby „usiłuje się przekształcić uniwersytet w szkółkę", podjęto wiele decyzji i wdrożono kolejne działania, które wydatnie wzmacniaja przekształcanie uniwersytetu w szkółkę, zintensyfikowano formy dozorowania i terror terminów (również w zakresie wzrastających wymogów sprawozdawczości).

Aby zapobiec formułowaniu nietrafnych i niedajacych się zrealizować wymagań wychowawczych, Jaspers przypomina: „Studenci to ludzie dorośli, nie dzieci. Sa dojrzali, ponoszą za siebie pełną odpowiedzialność" 55 . Narzucanie zadań wychowawczych uniwersytetowi oznacza - w pierwszym rzędzie - odbieranie samodzielności studentom i przyodzianie dorosłych osób w przyciasne dziecięce ubranka. Jaspers stwierdza: „Ze swobody nauczania wypływa swoboda uczenia się. Żad-

${ }^{53}$ M. Porębski, K. Czerni, Nie tylko o sztuce. Rozmowy z profesorem Mieczysławem Porębskim, Wyd. Dolnośląskie, Wrocław 1992, s. 20.

${ }^{54}$ Ibidem.

${ }^{55}$ K. Jaspers, Praca badawcza..., s. 743. 
ne przepisy, żaden nadzór nad studiami, jak w szkołach średnich, nie powinny krępować studenta uniwersytetu. Wolno mu "zejść na psy»"56. Dość mocno brzmiące stwierdzenie Jaspersa, w którym użyto dobitne powiedzenie zaczerpnięte $z$ języka potocznego, ma także ten walor, iż eksponujac swobodę studiowania, daje antidotum na będace dziś w modzie popadanie w umoralniajacy i moralizatorski o „wychowawczych" zdaniach uniwersytetu, które mają być podejmowane wobec dorosłych i samodzielnych osób.

Aby wzmocnić jeszcze przytoczone tezy i argumenty wyrażajace krytyczne podejście do postulatów wychowania przez nauczycieli akademickich, warto przytoczyć równie jednoznaczna i dość radykalnie brzmiaca odpowiedź na pytanie: „Czy przed wykładowca akademickim stoi zadanie wychowania studentów?”, której udzielił Śliwerski:

Nie, to jest podejście rodem $z$ minionego ustroju. My możemy co najwyżej wspierać dorosłych już ludzi w tym, by potrafili pracować nad soba, doskonalić się, ale zmieniać ich charakter czy postawy moga już tylko oni sami. Nie zwalnia nas to jednak $z$ tego, by dawać świadectwo kultury osobistej, wysokiej etyczności i profesjonalizmu. Jeśli chcemy to nazwać wychowaniem, to dobrze, ale pośrednim czy - jak pisała Ellen Key - niewidzialnym ${ }^{57}$.

Z punktu widzenia pedagogiki właściwie rozumiejacej zakres pojęcia wychowania i respektującej właściwy sens działań wychowawczych nie ma więc miejsca w przestrzeni uniwersytetu na grę pozorów i iluzji, iż dokonuje się „wychowanie studentów” przez nauczycieli akademickich, gdyż innego rodzaju są zasadnicze powinności i zadania kadry naukowo-dydaktycznej.

${ }^{56}$ Ibidem.

${ }^{57}$ Musimy wyjść z platońskiej jaskini. Rozmowa z prof. Bogusławem Śliwerskim, pedagogiem (rozmawiał Grzegorz Filip), https://forumakademickie.pl/fa/2012/01/ musimy-wyjsc-z-platonskiej-jaskini/. 


\section{Klasyczny etos uniwersytetu według Kazimierza Twardowskiego}

Kwestie zasad uniwersyteckie etosu rozpatruje Kazimierz Twardowski (1866-1938) ${ }^{58} \mathrm{w}$ wielokrotnie do dziś przywoływanej i komentowanej mowie $O$ dostojeństwie Uniwersytetu (21 listopada 1932 r. $)^{59}$.

$\mathrm{Na}$ plan pierwszy wysuwa się bezinteresowne dążenie do prawdy naukowej, które powinno być podstawowa cechą uniwersytetu. Jeśli spełnia się ten moralny wymóg, to można prowadzić rzetelne badania naukowe i tak kształtować studentów, aby potrafili samodzielnie uprawiać naukę ukierunkowana na odkrywanie prawdy. A nadto, przybliżanie się do prawdy bywa źródłem satysfakcji intelektualnej. Szczęście i radość osiaga się także dzięki poznawaniu prawdy. Dociekanie prawdy i analiza metod jej dochodzenia to główne zadanie filozofii, która ma swą misję wśród innych dziedzin nauki. $Z$ tego zadania powierzonego filozofii wynika jej „miejsce centralne” wśród nauk uprawianych na uniwersytecie. W pracy naukowej i w działaniu praktycznym cechą filozofa powinno być, że „nie poprzestaje na wykonywaniu czynności, lecz że

${ }^{58}$ Zob. J. Woleński, Filozoficzna szkoła lwowsko-warszawska, PWN, Warszawa 1985; R. Jadczak, Kazimierz Twardowski. Twórca szkoły lwowsko-warszawskiej, Wyd. Adam Marszałek, Torun 1991; W. Szulakiewicz, Działalność oświatowa i myśl pedagogiczna Kazimierza Twardowskiego, w: Historyczne źródła wybranych ofert edukacyjnych $w$ Polsce współczesnej, red. D. Drynda, D. Ekiert-Grabowska, W. Łuszczuk, Wyd. UŚ, Katowice 1996, s. 27-37; J. Woleński, Kazimierz Twardowski, w: Encyklopedia filozofii polskiej, t. II: $M-\dot{Z}$, red. A. Maryniarczyk, Polskie Towarzystwo Tomasza z Akwinu, Lublin 2011, s. 752-753; W. Szulakiewicz, O uczacych $i$ uczonych. Szkice z pedeutologii historycznej, Wyd. UMK, Torun 2014 (zwłaszcza rozdział II: Kazimierz Twardowski-nauczyciel uczonych i nauczycieli, s. 27-100); M. Rembierz, Wychowanie, oświata powszechna i kształcenie uniwersyteckie jako źródła polskiej niepodległości. Pedagogiczno-patriotyczne idee i działania Kazimierza Twardowskiego, „Polska Myśl Pedagogiczna” 2015, nr 1, s. 39-87.

${ }^{59} \mathrm{~K}$. Twardowski, O dostojeństwie uniwersytetu, w: idem, Wybór pism psychologicznych i pedagogicznych, red. R. Jadczak, WSiP, Warszawa 1992, s. 461-471. Z komentarzy i nawiązań do tekstu K. Twardowskiego O dostojeństwie uniwersytetu zob. m.in.: W. Stróżewski, O idei uniwersytetu, w: idem, W kręgu wartości, Znak, Kraków 1992, s. 7-26; J. Hołówka, Kazimierza Twardowskiego „O dostojeństwie Uniwersytetu”. Aktualność tradycyjnych idei, w: Autonomia Uniwersytetu. Jej przyjaciele $i$ wrogowie, red. J. Kieniewicz, POW Maciej Rysiewicz, Warszawa 2007; M.S. Szczepański, W. Ślęzak-Tazbir, O dostojeństwie Uniwersytetu i jego zagrożeniach. Społeczna rola i misja Uniwersytetu Śląskiego, w: Katowice $w 143$ rocznice uzyskania praw miejskich, red. A. Barciak, PAN, Katowice 2009, s. 78-89; R. Kleszcz, O godności nauczyciela..., s. 397-398; J.M. Brzeziński, Po co Akademia? O dostojeństwie nauki, „Nauka” 2012, nr 2, s. 21-31; Z. Drozdowicz, Ludzie uniwersytetu, „Nauka” 2013, nr 3, s. 35-57; U. Ostrowska, O wartościach ponadczasowych uniwersytetu $w$ myśli Kazimierza Twardowskiego, „Przegląd Pedagogiczny” 2014, nr 1, s. 90-100; J.M. Brzeziński, O powinnościach uniwersytetu, „Horyzonty Wychowania” 2014, vol. 13, nr 28, s. 343-358. 
postępowanie swoje, jego pobudki, metodę i cele, czyni przedmiotem własnej refleksji" ${ }^{60}$. To obowiązek dążenia do prawdy motywuje pogłębiona i wielopłaszczyznową refleksję (metarefleksję) towarzyszącą wszelkiej aktywności filozofa.

W życiu społecznym brakuje wszakże należnego uznania dla tych „wartości intelektualnych, którymi nas obdarzaja badania naukowe w postaci prawdy obiektywnej”61. Twardowski apeluje więc o „zrozumienie wartości prawdy naukowej”, wręcz o cześć dla niej. I stawia wciąż aktualne pytanie: „Komuż naprawdę na obiektywnej prawdzie zależy?”62. Jej wartości nie uznaja przecież ci, którzy dążą do celów osiaganych tylko wówczas, gdy działania „starannie będa prawdę omijały”63, gdy za pożądany (bo skuteczny) środek uważa się fałsz i przemilczenie. Rozwijany dzięki uprawianiu filozofii krytycyzm ma walory etyczne istotne w życiu społecznym. Jeśli filozofia czyni „przedmiotem badań samą prawdę, rozswietlajac drogi ku niej”, to w wymiarze społecznym jest sojuszniczka dążących „ku prawdzie”. Krytycyzm filozofii powstrzymuje „od ślepego ulegania autorytetom” oraz „od zbytniego ufania w nasz ludzki, tak bardzo ograniczony rozum”64. Nakazuje on „zwalczać wszelkie męty myślowe odurzające mglistościa”. Skłania do pracy nad jasnościa i ścisłością własnej argumentacji, aby osiagać w niej „uchwytność szczegółów i przejrzystość całości”65. Pozwala rozpoznać wiele - często dla nas niejawnych - założeń, które określają nasze postępowanie w życiu potocznym6.

\section{Idea universitas „,zagłuszana przez utylitaryzm, praktycyzm, technokracje”"}

Idee uniwersytetu rozpatrywane i uwydatnione przez Twardowskiego podją w swych uniwersytetoznawczych dociekaniach m.in. Stefan Swi-

\footnotetext{
${ }^{60}$ K. Twardowski, O dostojeństwie uniwersytetu..., s. 470.

${ }^{61}$ Ibidem.

62 Ibidem, s. 463.

${ }^{63}$ Ibidem.

${ }^{64}$ Ibidem, s. 469.

${ }^{65}$ Ibidem.

${ }^{66}$ Zob. ibidem, s. 469-470.
} 
eżawski (1907-2004), który studiował i doktoryzował się w kręgu Szkoły Twardowskiego ${ }^{67}$.

Patrząc na dokonujące się od połowy XX wieku i coraz dalej idące zmiany $\mathrm{w}$ funkcjonowaniu uniwersytetu $\mathrm{w}$ perspektywie „długiego trwania” dziejów filozofii i jej związku z idea uniwersytetu, Swieżawski zauwa$\dot{z ̇ a}$, że coraz bardziej „zanika sama idea uniwersytetu - universitas, idea zagłuszana coraz bardziej przez utylitaryzm, praktycyzm, technokrację"68, zagłuszana przez „produkcyjno-konsumpcyjne pojmowanie kultury”69. Nawet ta kultura, która ma być twórczo rozwijana na wyższych uczelniach, staje się częstokroć „kulturą w pigułce”, a oprócz tego jako nowe zagrożenia dla funkcjonowania klasycznie pojmowanego uniwersytetu powstaje „coraz więcej [...] uczelni wyższych zawodowych, zupełnie uniezależnionych od uniwersytetu" ${ }^{\prime \prime}$. Przygotowanie do zawodu staje się w nich „czysto utylitarne", a przecież - w kontekście tych idei, które stanowią fundament istnienia uniwersytetu - żaden „zawód nie może być traktowany tylko jako odrabianie zadań i realizowanie planu”, lecz powinien być postrzegany „jako prawdziwa twórczośśn ${ }^{\prime 11}$. Tak rozumiana twórczość jest możliwa we wspólnocie uniwersyteckiej stanowiącej obszar o swoistej wartości wynikającej ze „sprzęgnięcia doświadczenia wytrawnych uczonych i zapału młodych”72. Dopełnianie się tych pokoleniowo odmiennych sposób doświadczania (postrzegania) różnych wymiarów rzeczywistości jest jednym $z$ warunków zaistnienia i funkcjonowania uniwersytetu wedle idei universitas.

Jakie sa fundamentalne zadania, którym powinien pozostać wierny każdy z członków wspólnoty tworzącej uniwersytet? Sa to: uprawa nauki, tworzenie kultury i kształtowanie charakteru (paideia). Wśród nich „naczelnym zadaniem i racja bytu wszelkiego uniwersytetu jest rozwój

${ }^{67}$ Zob. M. Rembierz, Dialogus inter philosophum et christianum. Dorobek Szkoły Lwowsko-Warszawskiej w rozprawach i wspomnieniach Stefana Swieżawskiego, w: Polska filozofia analityczna. W kręgu Szkoły Lwowsko-Warszawskiej. Księga poświęcona pamięci Ryszarda Jadczaka, red. W. Tyburski, R. Wiśniewski, Wyd. UMK, Toruń 1999, s. 217-268.

${ }^{68}$ S. Swieżawski, Swoistość uniwersytetów wyznaniowych (pierwodruk „Więź” 1968, nr 9, s. 16-27) w: idem, Człowiek i tajemnica, Znak, Kraków 1978, s. 162.

\footnotetext{
${ }^{69}$ Ibidem, s. 165.

70 Ibidem, s. 162.

${ }^{71}$ Ibidem.

${ }^{72}$ Ibidem, s. 163.
} 
nauki”; w związku z tym „wszelkie inne, choćby najważniejsze i najwznioślejsze zadania" maja tu być podporzadkowane rozwojowi nauki ${ }^{73}$. To podporzadkowanie powinno być jednoznaczne: „na autentycznym uniwersytecie dobro nauki winno stać zawsze ponad dobrem dydaktyki i wychowania. A raczej dydaktyka i pedagogia maja służyć celowi naczelnemu uniwersytetu, jakim jest uprawa nauki"74. Wartość nauki ma mieć pierwszorzędny status w uniwersyteckiej przestrzeni wartości.

Uniwersytet „dążący do poznawczej pełni”, respektujacy universum zróżnicowanych i współdziałających $z$ sobą dyscyplin, starajacy się zbliżyć do swego ideału i kierujacy się nim jako idea regulatywną, wnosi w sama koncepcję nauki „element istotny, a będący dziś w wyraźnym zaniku, mianowicie uniwersalność, powszechność dyscyplin"75. Do urzeczywistniania klasycznej idei uniwersyteckości zbliża się „uniwersytet otwarty, czyli służący i chcaccy służyć rozwojowi nauki”, chcacy być prawdziwa universitas, a nie wassko wyprofilowanym i zredukowanym „uniwersytetem kadłubowym” ulegającym rozdrobnieniu na skutek „zabójczego przerostu specjalizacji"76, które uprawia się w separacji. Otwarcie na całość poznawczo wartościowej ludzkiej wiedzy, otwarcie na jej pomnażanie i na refleksję nad nią - ideologicznie nieskrępowana, wolną refleksję humanistyczna, filozoficzna, aksjologiczna i metodologiczna - powinno cechować uniwersyteckie podejście do uprawiania nauki i jej studiowania.

${ }^{73}$ Ibidem, s. 162.

${ }^{74}$ Ibidem, s. 164. S. Swieżawski zwraca też uwagę na istotny związek między uniwersytetem ukierunkowanym na naukę a szkolnictwem średnim: „Podstawowe dla społeczeństwa szkolnictwo średnie będzie takie, jakim je urobi szkoła wyższa. Kadra szkolnictwa średniego będzie się czuła zawsze kulturalnie pokrzywdzona, jeśli zostanie zupełnie odcięta od twórczości naukowej. Nauczyciel szkoły średniej powinien móc całe życie na swój sposób też budować naukę, a nie tylko spełniać zadania czysto dydaktyczno-administracyjne. Jakże na przykład cenne bywały sprawozdania $z$ działalności szkół średnich, które ukazywały się periodycznie, a zawierały przyczynki naukowe, których autorami byli nauczyciele szkół średnich" (ibidem, s. 165).

\footnotetext{
${ }^{75}$ Ibidem.

${ }^{76}$ Ibidem.
} 


\section{Postulat dystansu uniwersytetu \\ wobec „ścierających się prądów społecznych” a różne postacie i siła oddziaływania „uniwersytetu politycznego”}

W mowie $O$ dostojeństwie Uniwersytetu Twardowski podkreśla, że uniwersytet powinien zachować dystans wobec „ścierających się prądów społecznych"77. To jest jeden $z$ warunków koniecznych jego istnienia, od spełnienia którego nie można odstąpić, jeśli za jego konstytutywne zadania uznaje się: badania naukowe, krytyczną analizę ich metod i wyników oraz upowszechnianie wiedzy wśród studentów, którzy maja być tak ukształtowani, aby mogli dalej samodzielnie kontynuować wysiłek badawczy ich nauczycieli. Natomiast wikłając się w walkę światopoglądów i nierozstrzygalny naukowo spór ideologii, uniwersytet traci niezależność. Uniwersytet i odpowiedzialnie uprawiana w jego murach filozofia, zwłaszcza w sytuacji niesprzyjającej realizowaniu ich zadań, maja trwać jak „latarnia morska”, która światłem wskazuje drogę, ale „nigdy światła swego nie nurza w samych falach”. Gdyby to uczyniła, wówczas „światło by zgasło" i „okręty pozostałyby bez gwiazdy przewodniej”78. Dlaczego uniwersytet powinien konsekwentnie stronić od angażowania się w ideologiczne spory, wyjaśnia Władysław Stróżewski:

starcia ideologiczne maja $z$ reguły na celu nie tyle przezwyciężenie, co eliminację jednej ze stron [...]. Przeciwnik ideologiczny na ogół jest traktowany jako wróg. Nie odróżnia się przy tym człowieka i głoszonych przezeń poglądów. Walka ideologiczna kończy się prędzej czy później walką $z$ człowiekiem ${ }^{79}$.

Uniwersytet natomiast $\mathrm{u}$ swych podstaw zakłada afirmację człowieka i jego zdolności.

Kształcenie uniwersyteckie w XX wieku zmagało się $\mathrm{z}$ narzuconą sytuacja systemów totalitarnych zmierzajacych do pełnego podporzadkowania sobie zwłaszcza tej formy kształcenia. Funkcja uniwersytetu jako

\footnotetext{
${ }^{77}$ K. Twardowski, O dostojeństwie uniwersytetu..., s. 464.

78 Ibidem, s. 465.

${ }^{79} \mathrm{~W}$. Stróżewski, W poszukiwaniu istoty pokoju, w: idem, Istnienie i wartość, Znak,
} Kraków 1981, s. 310. 
latarni morskiej, która „nigdy światła swego nie nurza w samych falach”, uległa osłabieniu i wręcz okazała się całkowicie zagrożona.

$Z$ bezwzględnego niszczenia etosu uniwersytetu w systemie politycznym narzucanym przez hitleryzm zdawał sobie sprawę Edmund Husserl (1859-1938) ${ }^{80} \mathrm{w}$ przyjacielskim liście skierowanym do Romana Ingardena (1893-1970), liście datowanym 11 października 1933 roku: „Dawny niemiecki uniwersytet już nie istnieje, uniwersytet oznacza teraz "uniwersytet polityczny" "81. W tym zwięzłym i dramatycznym wyznaniu Husserla, osobiście także dotkniętego nazistowskimi represjami oraz wyrażającego troskę o los zagrożonych jego uczniów, uwydatniona zostaje drastyczna zmiana w sposobie funkcjonowania uniwersytetu, która bezwzględnie wymusza system totalitarny. Na ile jednak można uwagę Husserla uczynić bardziej uniwersalna i stwierdzić, że dawny uniwersytet już nie istnieje, uniwersytet oznacza teraz „uniwersytet polityczny”? $\mathrm{Na}$ ile ów uniwersytet polityczny, nie tylko w nazistowskiej formule, ale w różnych ideologicznych wariantach i odsłonach, aż po współcześnie funkcjonujace, wszedł w obszar dawnego uniwersytetu i pozostał w nim już na stałe, zmieniajac również od wewnatrz sposób funkcjonowania uniwersytetu, redukując i niwelujacc uniwersytecką wolność?

Zmaganie o wolność kształcenia uniwersyteckiego w obliczu systemów totalitarnych pozwoliło jednak zarazem na nowo odkryć etos nauki i nauczania, które powinno uprawiać się w przestrzeni uniwersyteckiej. Izydora Dambska (1904-1983) ${ }^{82}$, gdy komunistyczne władze administracyjno-polityczne podjęły w 1963 roku decyzję o jej usunięciu z Uniwersytetu Jagiellońskiego, powód tych represji widziała w wyrażanych przez siebie przekonaniach o niezbywalnych zadaniach uniwersytetu i filozofii. Józef Tischner (1931-2001) zaświadcza:

80 C. Beyer, Edmund Husserl, w: Stanford Encyclopedia...

${ }^{81}$ E. Husserl, Briefe an Roman Ingarden, mit Erlauterungen und Erinnerungen an Husserl, herausgegeben Roman Ingarden, Haga 1968, s. 83-84, cyt. za: I. Krońska, Wspomnienie o Profesorze Ingardenie, w: Fenomenologia Romana Ingardena, Wydanie specjalne „Studiów Filozoficznych", Warszawa 1972, s. 63.

82 Zob. J. Perzanowski, Rozum - serce - smak w myśli Profesor Izydory Dąmbskiej, w: Rozum - serce - smak. Pamiecci Profesor Izydory Dambskiej (1904-1983), red. J. Perzanowski, red. tomu P. Janik, Wyd. WAM, Kraków 2009, s. 13-22; W. Stróżewski, Philosophari necesse est, w: Rozum - serce..., s. 23-30. 
po raz pierwszy w życiu $z$ twardym mówieniem „nie” komunizmowi spotkałem się nie w Kościele, ale na uniwersytecie. Zdumiało mnie, kiedy po 1956 roku profesor Izydora Dambska napisała do rektora UJ protest przeciwko ustawie o szkolnictwie wyższym ${ }^{83}$.

Wedle tej ustawy należało kształtować studentów „w duchu socjalizmu, a profesor Dąmbska oświadczyła, że nie będzie tego respektować, bo ona wychowuje w duchu obiektywności naukowej" ${ }^{4}$. Aby jeszcze dobitniej zaakcentować moralny walor i szczególne znaczenie postawy Dąmbskiej Tischner dopowiada: „Wtedy po raz pierwszy spotkałem się z taka postawa, że słowo jest słowo..."85. Dąmbska głosiła, że filozofię należy uprawiać „bez ideologicznych założeń”, a

studia uniwersyteckie winny wychowywać młodzież przez zaprawianie jej do stosowania metod naukowej pracy, do samodzielności w myśleniu i przez rozwijanie w niej potrzeby bezinteresownego poszukiwania prawdy, a nie przez wytwarzanie w niej postaw ideologicznych ${ }^{86}$.

Wskazane przez Dąmbską kształtowanie umiejętności posługiwania się metodami naukowymi ma być zespolone $z$ formowaniem aksjologicznych przeświadczeń o szczególnych walorach samodzielności poznawczej i bezinteresownego poszukiwania prawdy, które powinno być uznane za zasadniczy cel pracy naukowej i dydaktycznej.

\section{Gaudium veritatis - postawa bezinteresowności poznawczej w kształceniu}

W kulturze europejskiej powoływanie uczelni akademickich i cel studiowania wiazano $z$ klasyczna idea gaudium veritatis: bezinteresownej radości, która daje dążenie i przybliżenie się do prawdy. Warto studiować przede wszystkim po to, aby osiagać lepsze poznanie i rozumienie rzeczywistości, co skutkuje również radością. Wśród założeń właściwie

83 J. Tischner, SPOTKANIE. Z ks. Józefem TISCHNEREM rozmawia Anna Karoń-Ostrowska, Znak, Kraków 2003, s. 45.

84 Ibidem.

85 Ibidem.

86 Cyt. za: R. Jadczak, I. Dambska i jej pozycja w Szkoła Lwowsko-Warszawskiej, „Toruński Przegląd Filozoficzny" 1997, nr 1, s. 122. 
ukierunkowanej edukacji znajduje się przekonanie, że bezinteresowne dążenie do prawdy ma wartość samo w sobie ${ }^{87}$.

Cechą szczególną kierunków studiów uniwersyteckich ma być to, iż ich głównym celem jest - jak podkreśla to m.in. Czeżowski - sama wiedza, a nie jej pozyskiwanie w celach praktycznych. Nauczanie uniwersyteckie jest wolne, natomiast rygor programu obowiazuje przy egzaminach uniwersyteckich:

\begin{abstract}
Egzaminy naukowe to przede wszystkim kolokwia. Sa one związane bezpośrednio $z$ tematem wykładów, obejmuja zakres podany w wykładzie, celem ich danie studentowi sposobności dla przekonania się, w jakiem mierze skorzystał $z$ wykładów, na które uczęszczał. Dziś kolokwia sa w zaniedbaniu. [...] Nikt nie ma czasu myśleć o bezinteresownym kolokwium [...]. Tak więc te egzaminy, które powinny mieć największe znaczenie w czasie studiów, bo wiążą się bezpośrednio z nimi, należą dzisiaj do rzadkości ${ }^{88}$.
\end{abstract}

Pod naporem pragmatyczno-utylitarnego podejścia do efektów studiów zanikaja swoiście akademickie formy działań dydaktyczno-kontrolnych, do których należy „bezinteresowne kolokwium” służące jedynie pomnażaniu i utrwalaniu wartościowej poznawczo wiedzy.

Obecny kryzys uniwersytetu Józef M. Bocheński (1902-1995) dostrzega w nacisku państwa na przetworzenie uniwersytetu w szkołę wyższa „w ścisłym tego słowa znaczeniu, tzn. zakład, w którym przygotowuje się ludzi do praktyki" 89 . W kontekście tego zagrożenia Bocheński przywołuje - za Jaspersem - i eksponuje ideał czystej nauki, która „jest jedna $z$ największych wartości, jakie zna ludzkość"90. Za najbardziej racjonalny projekt uniwersytetu Bocheński uznaje taki uniwersytet, na którym istnieje wydział centralny, na którym wykłada się nauki czyste (czyli czysta

87 Wedle T. Czeżowskiego podstawowe zadanie nauczania polega na tym, że: „Wskazuje ideał najbardziej wzniosły, najbardziej czysty, bo wyższy ponad wszelkie partykularne walki i pragnienia, ogólnoludzki ideał prawdy. Wszczepiając zaś bezinteresowna miłość do prawdy, buduje w duszach podstawy etyki”. T. Czeżowski, O stosunku nauki do państwa, Komisja Jubileuszowa Kasy im. Mianowskiego, Warszawa 1933, s. 12.

88 T. Czeżowski, O uniwersytecie $i$ studiach uniwersyteckich, Księgarnia Naukowa T. Szczesny, Toruń 1946, s. 13.

89 J.M. Bocheński, Między logika a wiarą. Z Józefem M. Bocheńskim rozmawia Jan Parys, Noir sur Blanc, 1995, s. 35.

90 Ibidem. 
matematyka, filozofia, teoretyczna biologia itd.): „Na około tego wydziału centralnego byłyby wydziały praktyczne, dla inżynierów, nauczycieli, proboszczów itd. Ale każdy z młodych miałby, przez cały czas studiów parę godzin tygodniowo na wydziale centralnym, kontakt $z$ czysta nauka" ${ }^{\prime 1}$. Aby mógł funkcjonować tak rozumiany uniwersytet jako instytucja ukierunkowana na wartość teorii i teoretycznego poznania, to niezbędne jest respektowanie jego autonomii ${ }^{92}$.

Postulowane zapoznanie się $z$ uprawianiem i wynikami „czystej nauki" ma być zarazem forma edukacji aksjologicznej, ma kształtować przekonania i postawy w zakresie wartości zespolonych $z$ nauką. Podstawowe zadanie każdego nauczyciela odpowiadającego za przebieg działań dydaktycznych polega na tym, aby „uczyć bezinteresownego podejścia do przedmiotu" - jak trafnie rzecz ujmuje Tischner ${ }^{93}$, wieloletni nauczyciel akademicki. Na wyrachowane pytanie ucznia lub studenta: „Co ja $z$ tego będę miał, że będę się czegoś uczył (będę coś studiował)?” zasadnicza odpowiedź powinna brzmieć: „Lepiej poznasz i zrozumiesz rzeczywistość, dlatego warto się uczyć i studiować”. Wszelkie praktyczne interesy sa sprawą wtórna wobec wartości poznawania prawdy.

We współczesnym systemie edukacji panuje jednak mentalność łapówkarska: oto ktoś uczy się lub studiuje głównie po to, aby w szkole za osiagnięta wiedzę dano mu dobrą ocenę. Oceny są częstokroć łapówkami, które nauczyciel wręcza uczniowi za to, że ten się czegoś nauczył. W takim systemie - opartym na swoistej korupcji - dokonuje się istotnej demoralizacji ucznia, gdyż zanika w nim bezinteresowne podejście do uczenia się i studiowania. Nie respektuje się tu postulatu odpowiedzialności za prawdę jako podstawę działań edukacyjnych. W polskiej filozofii zagadnienie roli prawdy w nauce i nauczaniu podejmował Jan Śniadecki (1756-1830). Dobitnie stwierdzał: „Miłość prawdy była i będzie zawsze panująca namiętnością twórczych umysłów"94. Należy tak kształcić, aby

\section{${ }^{91}$ Ibidem.}

${ }_{92}$ Zob. J.M. Bocheński, Autonomia uniwersytetu, w: idem, Sens życia i inne eseje, Philed, Kraków 1993, s. 60-71.

93 J. Tischner, Przekonać Pana Boga. Z ks. Józefem Tischnerem rozmawiaja Dorota Zańko i Jarosław Gowin, Znak, Kraków 1999, s.144.

${ }^{94}$ Cyt. za: W. Tyburski, Myśl etyczna $w$ Polsce od XVI do XIX wieku, Top Kurier, Toruń 2000, s. 308. 
uczeń potrafił twórczo zgłębiać i pomnażać wiedzę. Dzięki rzetelnej nauce - co podkreśla Śniadecki - uzyskuje się pokorę intelektualna warunkująca także tolerancję wobec odmiennych przekonań: „kto przedarł się przez ciernie i trudności jakiej nauki, widzi przed sobą częstokroć jeszcze twardsze trudności niż te, które pokonał, i nie może być zanadto skromny" ${ }^{\prime 95}$. Zyskując wiedzę, zarazem rozpoznajemy obszary własnej niewiedzy. Śniadecki wskazywał też na taką prawidłowość: „Im więcej zgłębiamy się w naukę, tym więcej uczymy się poznawać, jak nam wiele brakuje”. Jeśli natomiast brakuje pokory, to na plan pierwszy wychodza „próżność i nadętość w umiejętnościach”, które sa czytelnym „znakiem słabej głowy, niezdolnej do zgłębiania tego, co się w niej zawiązało i utkwiło". $Z$ powodu błędnej edukacji przybywa - jak przestrzega Śniadecki - „niedouczonych półmędrków, którzy przedsionek nauk biora za ich granicę, a szczupłe zapasy ich wiadomości za wszystkie rozumu ludzkiego zdobycze"96.

Jeśli działania edukacyjne rozmijają się $z$ bezinteresownym dążeniem do prawdy, to skutkuja kształtowaniem „umysłów zamkniętych”, które nie sa otwarte na poszukiwanie prawdy. Szkolna produkcja - wręcz na masowa skalę - „niedouczonych półmędrków” jest niebezpieczna dla jakości wiedzy naukowej i jakości życia społecznego. Gdy dziś panuje masowość kształcenia akademickiego, to na uwagę zasługuje też osąd Jaspersa: „Nie należy do uniwersytetu ten, kto zalicza studia po to, by wyrobić sobie lepsza pozycję, kto wkuwa na egzamin"97. Bezinteresowne zdobywanie rzetelnej wiedzy stanowi - w zaprezentowanym tu ujęciu warunek rzeczywistego uczestnictwa w edukacji uniwersyteckiej.

\section{Uwagi końcowe}

W zmaganiach o urzeczywistnianie się Uniwersytetu postrzeganego jako swoisty świat manifestujacych się wartości i cenionych postaw osobowych nie można poprzestać na snuciu marzeń o „złotym wieku”, który nieodwołalnie przeminąl. Osoby współcześnie stanowiące społeczność akademicka powinny wykazać się odpowiednią wiedzą na temat uniwer-

\footnotetext{
95 Ibidem.

96 Ibidem, s. 309.

${ }^{97}$ K. Jaspers, Praca badawcza..., s. 748.
} 
sytetu (wiedzą uniwersytetoznawcza), wiedza teoretyczną i praktyczna o bliskiej im rzeczywistości (której doświadczaja, w której uczestnicza, która współtworza), a zarazem powinny wykazać się silnym przekonaniem o własnej podmiotowości i sprawczości, zdolności do czynu fundującego i podtrzymującego Uniwersytet, aby nie ulec wzmożonej perswazji o dziejowych i cywilizacyjnych determinantach (wyrażających się w administracyjnych zarządzeniach), którym społeczność akademicka ma się bezwarunkowo podporzadkować. Trzeba podtrzymywać i wzmacniać nadzieję, że urzeczywistnianie Uniwersytetu wciąż jest możliwe i pożąane; nie należy zagubić i zaprzepaścić tej nadziei, która jest zespolona $z$ istnieniem uniwersytetów, a ogólniej - jest zespolona $z$ edukacją, której wiedzotwórcza i kulturotwórcza działalnośc uniwersytetu w szczególny sposób daje wyraz ${ }^{98}$.

Aby nie zatracić aksjologicznie nasyconej idei i wizji Uniwersytet, niezbędne jest konsekwentne prowadzenie teoretycznie pogłębionej, systematycznej i wielokierunkowej, a także etycznie i praktycznie wiążącej refleksji o tożsamości uniwersytetu i jej przemianach. Tak prowadzona refleksja powinna przyczyniać się do urzeczywistnienia Uniwersytetu, który - ze wglądu na faktyczne i aktualnie się przejawiające dostojeństwo - można zapisywać z dużej litery. Choć wszelką wzniosłość należy wyrażać zdecydowanie powściagliwie, aby akty nadmiernej ekspresji nie utraciły swej wiarygodności i nie stały się komiczną gra pozorów lub - co gorsza - nie stały się uwodzacym syrenim śpiewem, który pociaga w topiel. Uniwersytetu, mimo częstokroć podnoszonego larum (które było także w przedstawionych tu wywodach przywoływane i rozpatrywane), nie trzeba wyłącznie postrzegać jako kulturowego fenomenu, który zszedł ze sceny dziejów i pograżył się w nieprzeniknioności tego, co już zamierzchłe. Uniwersytet zdaje się bowiem być wciąż przed nami jako humanistyczne (prawdziwie ludzkie, człowiecze) zadanie i wyzwanie, któremu - dzięki rzetelnej wiedzy i sprawności działania - trzeba umieć sprostać, wytwarzając, rozwijając i zachowując wspólnotę uniwersytecka. To zadanie i wyzwanie w szczególności adresowane jest - ze względu na zobowiązania

${ }^{98}$ A. Murawska, Uniwersytet jako przestrzeń kultury - płonne nadzieje? niespełnione obietnice?, w: Edukacja, moralność, sfera publiczna, red. J. Rutkowiak, D. Kubinowski, M. Nowak, Verba, Lublin 2007, s. 316-334; eadem, Edukacja jako troska o nadzieje człowieka, wyd. US, Szczecin 2008. 
profesjonalne i tradycję akademicką - do filozofów i pedagogów, gdyż to oni - wspólnie - dysponuja intelektualnym instrumentarium, aby trafnie rozpoznawać i określać, w jaki sposób w danych warunkach kulturowych i cywilizacyjnych najodpowiedniej można współtworzyć Uniwersytet, który będzie promieniował swymi wartościami mimo naporu ideologicznych, ekonomicznych i politycznych nacisków.

Słowa kluczowe: uniwersytet, wolność, niezależność, bezinteresowność, przemiany tożsamości uniwersytetu

\section{UNIVERSITY - LIBERTY - SELFLESSNESS. THE TRADITIONAL ETHOS AND CONTEMPORARY CHANGES IN THE IDENTITY OF UNIVERSITY}

\section{Summary}

What currently becomes more and more vivid is the public debate on the transformations in the functioning of university and on their directions. In order to focus properly on the problems undertaken here, it is worth to refer to some remarks on academic liberty and the liberty of studying, which are formulated in the context of describing the secret university education in Poland under the Nazi occupation. It is this secret teaching, based on self-organization and free from an administrative institutional framework, which turns out to be the model of university liberty. This peculiar experience of academic freedom, showing the essence of academic learning and teaching, should be remembered and taken into account in all political and administrative (or even bureaucratic) attempts at regulating the functioning of autonomic university and other academic level schools.

The current state of university is vividly depicted, as Kazimierz Denek does this, as a "switchback bend" situation. The switchback bend is a condition of increased risk and danger as, with the lack of skills or attention, it is easy to fall out of the route from a "sharp bend". However, it is also possible to become strengthened with new experiences and skills. Especially for educationalists and philosophers of education, university situated at a "bend" constitutes a challenge to thoughtful and in-depth reflection and reasonable acting - not to "risky charging" in the name of some fashionable "lofty words" and ideological visions.

What is recognized in the classically understood European culture is the specific identity of university and its irreducibility to other - even closely related 
- cultural forms. Universities are to embody in a specific way the ethos of intellectual work and to manifest some cognitive values at which practicing science and the system of education are aimed. Among other forms of shaping intellectual culture, university should be distinguished by its aiming at the holistic recognition of the reality or at least to unite the aspect-related recognition of the reality into a relative whole.

The issues of university ethos were considered by Kazimierz Twardowski (1866-1938) in his - widely commented today - speech "On the eminence of University" (2 $1^{\text {st }}$ November 1932). What comes to the foreground is the selfless aiming at the scientific truth, which should be a basic feature of university. If this moral requirement is fulfilled, it is possible to conduct reliable studies and to shape students in such a way that they could - on their own - practice science oriented towards discovering the truth. In the European culture, establishing universities and the aim of studying have been associated with the classical idea gaudium veritatis: selfless joy provided by aiming at and approaching the truth.

In the efforts to fulfil university, viewed as a specific world of manifested values and appreciated personal attitudes, the dreams about the "golden age" which has already gone cannot be the end. The people who constitute the academic community ought to present the appropriate knowledge of university, the theoretical and practical knowledge concerning their close reality, and they should have a strong belief in their own subjectivity and agency, their ability to establish and maintain university. This should take place in order not to yield to persuasion on civilization determinants (expressed in administrative directives) to which the academic community is to be unconditionally subjected.

Keywords: university, liberty, autonomy, selflessness, transformations of university identity 


\section{Anna Sajdak}

Uniwersytet Jagielloński

\section{Nauczyciel akademicki - dylematy, napięcia, ambiwalencja roli}

\section{Wprowadzenie}

Funkcjonowanie nauczyciela akademickiego w świecie nauki i uniwersytetu można opisać $z$ wielu perspektyw teoretycznych. W ostatnich dekadach jednym $z$ bardziej inspirujacych i płodnych badawczo jest horyzont krytyczny pozwalający pokazać uwikłanie człowieka uniwersytetu w szereg napięć generowanych ze starcia odmiennych ideologii, racjonalności, podejść, koncepcji i wizji uniwersytetu ${ }^{1}$. W przestrzeni publicznej mocno zaznaczył się dyskurs ekonomiczny, a logika rachunku ekonomicznego nierzadko stała się podstawą nie tylko kreowania porządku edukacyjnego w szkolnictwie wyższym, ale także wymagań stawianych nauczycielowi akademickiemu i systemu oceny jego pracy. To tylko rama dla zarysowania szczegółowego pola badawczego - funkcjonowania nauczyciela akademickiego $\mathrm{w}$ roli dydaktyka $z$ punktu widzenia doświadczania przez niego złożoności, napięć i ambiwalencji roli zawodowej. W społeczności akademickiej najczęściej jesteśmy naukowcami - matematykami, biologami, filozofami, socjologami itd., a niejako „przy okazji” zostaliśmy zaangażowani w proces kształcenia studentów. Bycie nauczycielem akademickim - czynnym dydaktykiem - jest często traktowane jako wtórne wobec roli naukowca. Zdarza się nawet, że obowiąki dydaktyczne sa postrzegane jako niepotrzebnie angażujące, „odciagające” lub nawet utrudniajace prawdziwe uprawianie nauki². Aby zostać na-

1 Zob. prace M. Czerepaniak-Walczak, Z. Melosika, T. Szkudlarka, M. Dudzikowej, E. Potulickiej, T. Bauman, M. Malewskiego, J. Rutkowiak, K. Denka, T. Lewowickiego i innych.

2 Z przedstawionym powyżej poglądem bardzo często spotykam się podczas spotkań $z$ doktorantami i nauczycielami akademickim poświęconych wspieraniu ich kompetencji dydaktycznych. 
uczycielem akademickim, trzeba spełnić określony standard naukowy, który najczęściej wyczerpuje opis kompetencji/osiągnięć naukowych - merytorycznych i metodologicznych $z$ danej dyscypliny oraz/lub doświadczenie w projektach badawczych. Czasem w warunkach konkursu na dane stanowisko pojawia się enigmatyczna „umiejętność prowadzenia zajęć ze studentami”. To spuścizna wielowiekowej tradycji uniwersyteckiej uznajacej nauczyciela akademickiego przede wszystkim za naukowca czynnie prowadzącego badania, upowszechniającego wyniki swojej pracy i osiagnięć danej dyscypliny ${ }^{3}$. W tej perspektywie umiejętność prowadzenia zajęć dydaktycznych ze studentami konstytuowana jest przez pasję naukowa i bycie ekspertem w danym obszarze ${ }^{4}$. Rozwijanie siebie w roli nauczyciela akademickiego w różnych okresach swojego funkcjonowania w zawodzie, wspieranie różnorodnych obszarów swych kompetencji do prowadzenia zajęć (związanych $z$ dydaktyką ogólną i przedmiotowa, społecznych, systemowych i osobowych ${ }^{5}$ ) ciągle wydaje się jeszcze całkowicie prywatna sprawa każdego $z$ nas.

Swój głos w dyskusji buduję wokół tezy, iż znacząca część dylematów nauczyciela akademickiego związana jest $z$ doświadczaniem różnego rodzaju napięć, ambiwalencji wpisanych w rolę zawodową. Poruszę zatem kwestię samej kategorii ambiwalencji oraz dwóch głównych obszarów jej doświadczania, rozwinę tropy związane $z$ praca dydaktyczna ze studentami, by w ten sposób nakreślić horyzont dla procesów budowania samoświadomości siebie w roli nauczyciela akademickiego - właśnie dydaktyka. W końcowej refleksji znowu wrócę do kategorii ambiwalencji,

3 O takiej konstytucji edukacji akademickiej pisał w pierwszej połowie XX w. np. S. Hessen, Podstawy pedagogiki, tłum. A. Zieleńczyk, Żak, Warszawa 1997, s. 377.

4 Poglacdy takie sa ciągle obecne i artykułowane w przestrzeni uniwersyteckiej. Przykładem może być oryginalny list jednego $z$ dziekanów uniwersytetu, który na ofertę nieodpłatnych i nieobowiazkowych warsztatów dla nauczycieli akademickich podnoszacych ich kompetencje dydaktyczne zareagował w następujący sposób: „marnotrawia Państwo publiczne środki, na moim wydziale wszyscy, absolutnie wszyscy pracownicy doskonale potrafia prowadzić zajęcia dla studentów, bo są ekspertami w swojej dziedzinie, a przecież liczy się tylko ich rozwój naukowy".

5 Zdaniem I. Stahr kompetencje nauczyciela akademickiego, które pozwalaja mu funkcjonować w roli dydaktyka, tworza kompetencje związane $z$ dydaktyką ogólna, $z$ dydaktyka przedmiotowa, społeczne, osobowe i systemowe. Zob. I. Stahr, Academic Staff Development: Entwiclung von Lehrkompetenz, w: Wander der Lehr- und Lernkulturen, red. R. Schneider, B. Szczyrba, U. Welbers, J. Wildt, W. BertesmannVerlag, Bielefeld 2009, s. 80. 
gdyż jej doświadczanie może być życiodajne. Jak bowiem twierdzą badacze przedmiotu, doświadczenie konfliktu roli może stać się źródłem uruchomienia ważnych procesów emancypacji od Alma Mater.

\section{Kategoria ambiwalencji i jej użyteczność w refleksji nad rolą nauczyciela akademickiego}

Termin „ambiwalencja” w wielu pracach pedagogicznych odczytywany jest jako pewna chwiejność, niedookreślenie, dwuznaczność. Zdaniem Lecha Witkowskiego ${ }^{6}$, który zrewitalizował w obszarze polskiej myśli pedagogicznej tę kategorię, wiąże się to być może $z$ błędnym wpisywaniem jej w dyskurs porzadku ponowoczesnego. Autor pisze:

analizujacc badawczo „profile i tropy ambiwalencji w kulturze”, umiem pokazać, sięgając do dyscyplin humanistycznych [...], że od przełomu lat sześćdziesiątych i siedemdziesiatych XX wieku następuje zmiana paradygmatyczna perspektywy widzenia kwestii „porządku” i ograniczeń „jednoznaczności”

Zdaniem Witkowskiego zmiana ta, swoiste przewartościowanie kategorii, może stać się płodnym tropem dla nowoczesnej teorii pedagogicznej $^{8}$. Ambiwalencja wcale nie musi oznaczać dezintegracji, deficytu, chaosu czy chwiejności, ale po prostu „oscylowanie” czy niepojoratywne „nierozstrzygnięcie”, pozostawanie w polu działania przeciwstawnych sił, pewnego rodzaju napięcie wynikające $z$ porzucenia pewności oraz akceptacji różnorodności. W podobnym znaczeniu używa tej kategorii Henryka Kwiatkowska. Zdaniem autorki ambiwalencja stała się „integralnym czynnikiem kondycji ludzkiej i złożoności współczesnego świata”" . Niezwykle ważne tezy Kwiatkowskiej traktującej ambiwalencje jako podsta-

6 Zob. L. Witkowski, Między pedagogika, filozofia i kultura. Studia, eseje, szkice, t. III, IBE, Warszawa 2007, s. 177.

7 Ibidem.

8 Zob. L. Witkowski, Ambiwalencja w kulturze jako wyzwania dla pedagogiki ogólnej, w: Rozwój pedagogiki ogólnej. Inspiracje i ograniczenia kulturowe oraz poznawcze, red. A. Bogaj, Akademia Świętokrzyska im. Jana Kochanowskiego w Kielcach, Warszawa-Kielce 2001 , s. 58 .

9 H. Kwiatkowska, Pedeutologia, Wydawnictwa Akademickie i Profesjonalne, Warszawa 2008 , s. 200. Autorka odwołuje się do stwierdzenia L. Witkowskiego w pracy Ambiwa- 
wowy składnik kondycji intelektualnej współczesnego nauczyciela warunkujący jego rozumne pojmowanie niejednoznaczności świata wydaja się adekwatne także dla sytuacji nauczyciela akademickiego. W bycie nauczycielem akademickim wpisany jest pewien konflikt roli, który można rozpatrywać przynajmniej na dwóch różnych poziomach napięć ${ }^{10}$ :

1. Ambiwalencja jako napięcie wynikajace $z$ pozostawania w polu przeciwstawnych oczekiwań oraz normatywnych wymagań roli zawodowej pisanych przez pracodawcę (reprezentowanego przez władze uczelni), a wyrażających się $\mathrm{m}$.in. niespójnością stawianych zadań $z$ systemem oceny $i$ awansu pracownika, a zatem ambiwalencja wpisana $\mathrm{w}$ triadę bycia jednocześnie naukowcem, dydaktykiem oraz pewnego rodzaju menedżerem.

2. Ambiwalencja jako napięcie wynikające $z$ różnorodności i wzajemnej sprzeczności roli dydaktycznej nauczyciela akademickiego, który nierzadko musi jednocześnie występować jako nauczający ekspert - prowadzacy kanoniczne wykłady, trener zajęć warsztatowych stwarzajacy okazje do samodzielnego uczenia się studentów, animator wspólnych doświadczeń czy też empatyczny tutor wspierajacy indywidualna ścieżke rozwoju danej osoby. Każda $z$ tych ról wymaga nie tylko innego rodzaju zasobów osobowych, innego instrumentarium dydaktycznego, innego typu relacji, więzi ze studentami, ale również i określonego „etapu rozwojowego" w stawaniu się nauczycielem akademickim. Ten typ napięcia można scharakteryzować zatem zarówno w wymiarze sprzeczności ról dydaktycznych, jak i możliwego „niedopasowania” fazy rozwoju nauczyciela akademickiego do pełnienia danej roli. Tu zaryzykuję tezę, iż każda $z$ tych ról wymaga wejścia w odmienny paradygmat dydaktyczny konstytuujący proces kształcenia studentów, który wymaga uruchomienia $\mathrm{w}$ nauczycielu akademickim całkiem innych zasobów.

lencja jako kategoria dla socjologii edukacji, w: Edukacja wobec zmiany społecznej, red. J. Brzeziński, L. Witkowski, Edytor, Poznań-Toruń1994, s. 190.

10 Oczywiście poziomów doświadczania ambiwalencji roli zawodowej może być więcej. W pracy A. Sajdak, Paradygmaty kształcenia studentów i wspierania rozwoju nauczycieli akademickich. Teoretyczne podstawy dydaktyki akademickiej, Impuls, Kraków 2013, s. 187-191 przedstawiona jest propozycja trzech wymiarów. 


\section{Triada ról nauczyciela akademickiego: naukowiec-dydaktyk-menedżer}

Pierwszy obszar doświadczania ambiwalencji zwiąany jest $z$ charakterystyka roli nauczyciela akademickiego uwikłanego w różnorodne role, funkcje i zadania zawodowe. Wielość i specyfika wymagań powoduje, iż nauczyciel akademicki znajduje się niejednokrotnie w polu działania przeciwstawnych sił zwiazanych $z$ wymaganiami rozwoju naukowego (przygotowywania projektów badawczych, prowadzenia badań, publikowania prac naukowych, udziału w konferencjach), od którego właściwie zależy zatrudnienie i awans, $z$ odpowiedzialnościa za proces dydaktyczny względem studentów oraz $z$ oczekiwaniami przełożonych i władz uniwersytetu odnośnie do podejmowania różnorodnych prac organizacyjnych na rzecz uczelni i całej społeczności akademickiej. Chociaż w większości prac naukowych poświęconych uniwersytetowi oraz kształceniu uniwersyteckiemu wskazywane sa dwie główne role nauczyciela akademickiego - jako badacza-naukowca i jako nauczyciela - dynamiczne zmiany ostatnich dziesięcioleci pozwalają odpowiedzialnie wskazać jeszcze trzecia rolę - rolę menedżera. Tak pojawia się zasadnicza triada bycia jednocześnie naukowcem, dydaktykiem i organizatorem (menedżerem), która ma swoje odzwierciedlenie w systemie oceny pracownika. Warto na chwilę zatrzymać się przy tej triadzie, przy jej poszczególnych trybach, by uzmysłowić sobie, jak różnorodnych, a czasem i wykluczajacych się umiejętności wymaga bycie nauczycielem akademickim.

Bez watpienia zasadniczym rdzeniem i sensem pracy w uniwersytecie jest praca naukowa. Co to znaczy być dobrym naukowcem? Jakiego rodzaju umiejętności wymaga praca naukowa? Redukując ogrom literatury na ten temat, podążę tropem Michała Hellera, który pisze, iż nie trzeba być geniuszem, by uprawiać naukę, ale wystarczajacca legitymacja sa dobre zdolności i pasja naukowa, która oznacza m.in. ${ }^{11}$ : zainteresowanie przedmiotem, a nawet pewnego rodzaju utożsamianie się $z$ nim; znajdowanie przyjemności w pracy naukowej, w tych chwilach, które łącza się ze zmaganiem $z$ własna niemoca, trudnościami i zmęczeniem w nadziei na te nieliczne chwile przeżywanej $z$ rzadka radości, a nawet naukowej ekstazy; odwaga bycia trochę innym, czyli pewna psychiczna odmienność

${ }^{11}$ Zob. M. Heller, Jak być uczonym, Znak, Kraków 2009, s. 19-29; A. Sajdak, Paradygmaty kształcenia..., s. 178-179. 
wynikająca ze specyficznych zainteresowań związanych z uprawianiem nauki i poświęcaniem jej ogromnej ilości czasu; motywacja do pracy naukowej oznaczająca gotowość do „spędzenia nieograniczonej wprost liczby godzin za biurkiem lub $\mathrm{w}$ laboratorium pomimo braku uznania ze strony otoczenia i często wbrew rozmaitym administracyjnym zobowiązaniom"12. Tak pojmowana pasja naukowa będąca u podstaw pracy naukowej staje się zobowiązaniem oddania się nauce, zaangażowania wszelkich swoich zasobów w pracę badawcza. Jak Autor podkreśla, „zreszta $z$ czasem przychodzi - nasilajace się $z$ upływem lat - rozsmakowanie w naukowych zmaganiach i wtedy każdą chwilkę, jaką się musi poświęcić konwencjonalnym przyjemnościom, uważa się już bez żadnego poczucia wyższości) za stratę czasu" ${ }^{13}$. Poświęcanie się czemuś innemu niż nauce bywa uważane za stratę czasu również przez część osób strukturalnie zajmujących się oceną pracownika. W tym jednak wypadku „romantyczna” wizja naukowca oddającego się pasji dociekania Prawdy zderza się z koniecznością rozliczenia własnej aktywności według określonych kryteriów i zmierzenia się $z$ systemem określania jej wartości według przyjętego systemu punktów. W każdej ocenie pracownika naukowo-dydaktycznego na pierwszym planie wszelkich sprawozdań zawsze jest działalność naukowa, którą należy opisać, wykazując np. ${ }^{14}$ :

a) publikacje naukowe - książki, monografie, artykuły w czasopismach naukowych ( $z$ listy MNiSW A, $z$ listy MNiSW B, z listy MNiSW C), rozdziały w ksiażkach, redakcja czasopism, redakcja monografii; całości zostaje przypisana odpowiednia i zgodna ze standardami MNiSW wartość punktów;

b) badania naukowe - granty i projekty finansowane ze środków krajowych oraz zagranicznych; tej działalności również zostaja przypisane punkty;

c) wskaźniki cytowalności - sumaryczny współczynnik IF, liczba cytowani, indeks Hirscha;

\footnotetext{
${ }^{12}$ M. Heller, Jak być uczonym, s. 21.

13 Ibidem.

${ }^{14}$ Podstawa wymienionych kryteriów czynię aktualnie obowiązujący Formularz Oceny Nauczyciela Akademickiego w Uniwersytecie Jagiellońskim.
} 
d) konferencje naukowe - czynny i bierny udział w konferencjach krajowych oraz wmiędzynarodowych, publikacja w materiałach konferencyjnych;

e) wdrożenia, patenty, prace eksperckie;

f) zaawansowanie pracy na stopień (doktorskiej, habilitacyjnej);

g) staże naukowe krajowe i zagraniczne, urlopy i stypendia naukowe;

h) popularyzację wiedzy naukowej - książki popularnonaukowe, artykuły w czasopismach popularnonaukowych, publikacje w materiałach konferencyjnych popularnonaukowych.

Być może nie było to zamysłem osób wprowadzajacych swego rodzaju parametryzacje pracy nauczyciela akademickiego, zwłaszcza w zakresie działalności naukowej, ale efektem ubocznym stała się coraz silniej odczuwana potrzeba świadomego zarzadzania własna kariera nauko$\mathrm{wa}^{15}$. Ocena w trybie dwuletnim konkretnych efektów - osiagnięć, a nie projektu „bycia na drodze poszukiwañ” - skazuje na przegrana pomysły badań, które nie daja szybkich wyników, które nie przysparzaja punktów, które są podążaniem w nieznane i niepewne. Trzeba być zatem menedżerem własnej kariery. Praca na uniwersytecie obfituje w wiele zadań wymagających uruchomienia w sobie zasobów kompetencji „menedżerskich”. Wprowadzenie do sfery szkolnictwa wyższego mechanizmów rynkowych, zmiana systemu finansowania badań naukowych otworzyły przed nauczycielem akademickim zupełnie nowe obszary wyzwań zawodowych. Do podstawowych, wymaganych umiejętności naukowych dołączyły m.in. umiejętność pozyskiwania funduszy z różnego rodzaju grantów, sprawność w sporządzaniu projektów badawczych, wypełniania kwestionariuszy, bilansowania i rozliczania środków. Do tego wszystkiego konieczna jest znajomość odpowiednich przepisów prawa pozwalajaca kwalifikować dane koszty, a przy projektach międzynarodowych - znajomość prawa Unii Europejskiej. Od nauczyciela akademickiego wymaga się także zaangażowania w kwestie organizacyjne. Ocenie podlega zatem np. pełnienie funkcji w uniwersytecie, udział w pracach organizacyjnych na rzecz uczelni (typu Dni Otwarte, Festiwale Nauki, praca w komisjach), praca na rzecz środowiska naukowego (bycie członkiem i praca w orga-

15 A nawet jeśli taka potrzeba nie jest odczuwana, to jest kreowana przez różnego rodzaju szkolenia. 
nizacjach, stowarzyszeniach, komitetach), organizowanie konferencji, sekretarzowanie różnym przedsięwzięciom naukowym i popularyzacyjnym. Pożądanymi atrybutami - zwłaszcza w czasach niżu demograficznego i rywalizacji o studenta - stały się również umiejętności marketingowe związane $z$ promocją uczelni i danego kierunku studiów.

Bycie dobrym naukowcem i bycie sprawnie zarządzajacym administratorem, menedżerem to dwie osobne ścieżki rozwoju, dwa rodzaje działalności, które wymagają zupełnie inaczej ukierunkowanej energii, innego gospodarowania czasem, innych zasobów osobowych. I tak nieunikniony staje się konflikt dwóch porządków, dwóch racjonalności, na który, rozpoznając pola funkcjonowania homo academicus w świecie homo oeconomicus, zwraca uwage Maria Czerepaniak-Walczak ${ }^{16}$. Rywalizujące ze soba orientacja na naukę oraz orientacja na rynek i administrowanie staja się źródłem wielu napięć poprzez generowanie roszczeń i wymagań pod adresem nauczyciela, czyniąc zeń zarówno naukowca, jak i menagera. Właśnie ów zwrot: „zarówno - jak” staje się charakterystycznym atrybutem ambiwalencji.

Kolejnym ważnym obszarem pracy nauczyciela akademickiego jest bycie dydaktykiem. W pełni zgadzam się $z$ Leszkiem Kołakowskim, który w eseju o uniwersytecie napisał: „nie jest dobrze, jeśli traktujemy nauczanie jako uciążliwy dodatek do właściwej pracy, podczas gdy jest ono naszą racją istnienia w murach uczelni" ${ }^{17}$. Działalność dydaktyczna każdego nauczyciela akademickiego określona pensum dydaktycznym sprowadzana jest najczęściej do prowadzenia określonej liczby godzin zajęć ze studentami, w tym wykładów, seminariów, konwersatoriów, ćwiczeń, warsztatów czy laboratoriów. Praca dydaktyczna rzadko cieszy się prestiżem porównywalnym $z$ praca naukowa. Ma to swoje odzwierciedlenie również w systemie oceny pracownika ${ }^{18}$. Nie brak i stanowisk wyrażają-

16 Zob. M. Czerepaniak-Walczak, Homo academicus $w$ świecie homo oeconomicus. O obszarach $i$ przejawach zmagań $z$ akademickim zniewoleniem, „Pedagogika Szkoły Wyższej” 2014, nr 1, s. 11 i n.

17 L. Kołakowski, Po co uniwersytet?, „Gazeta Wyborcza” 1994, nr 61, s. 10.

${ }^{18}$ Najczęściej pomimo oceniania trzech obszarów pracy nauczyciela akademickiego działalności naukowej, dydaktycznej i organizacyjnej - to praca naukowa jest wyznacznikiem oceny pracownika naukowo-dydaktycznego, chyba że dopuszcza się on karygodnych zaniedbań w dydaktyce. Może być jednak inaczej, czego przykładem jest system oceny pracownika obowiązujący w Uniwersytecie Jagielloński. W zarządzeniu nr 57 Rektora UJ z 25 
cych się stwierdzeniem, iż dydaktyka stanowi „kulę u nogi” dla nauczyciela akademickiego lub jest w jego pracy przysłowiowym „piątym kołem u wozu"19. Nic więc dziwnego, że problem przygotowania nauczycieli akademickich do prowadzenia zajęć jest rozwiązywany w bardzo różny sposób - od całkowitego ignorowania (a nawet głosów, iż przygotowanie takie może być szkodliwe! $\left.{ }^{20}\right)$ po dobrze przemyślane systemy obowiązkowych szkoleń i ustawicznego wsparcia.

Mimo sformułowanego w lipcu 2013 roku przez unijna grupe wysokiego szczebla ds. modernizacji szkolnictwa wyższego pracujaca pod przewodnictwem prezydent Irlandii Mary McAleese zalecenia nr 4 mówiącego o tym, że każdy nauczyciel akademicki winien do 2020 roku odbyć certyfikowane szkolenie pedagogiczne, a doskonalenie w roli nauczyciela powinno stać się obowiązkowe ${ }^{21}$, wciąż nie mamy rozwiąania promującego przygotowanie dydaktyczne. By zostać nauczycielem akademickim, należy przede wszystkim sprostać wymaganiom naukowym stawianym przez uczelnie w otwartych konkursach na dane stanowisko. Wymagania natury dydaktycznej zawarte sa zwykle w enigmatycznym haśle typu „doświadczenie w prowadzeniu zajęć za studentami”. Stanowisko takie ma niewątpliwie swe źródło w tradycji uniwersyteckiej, w myśl której kompetencje do prowadzenia zajęć ze studentami legitymizowane sa przede wszystkim przez wysokie kompetencje merytoryczne naukowca, znajomość warsztatu metodologicznego danej dyscypliny naukowej oraz pewna praktykę w prowadzeniu procesu nauczania-uczenia się w szko-

czerwca 2014 r. w sprawie okresowych ocen nauczycieli akademickich UJ w roku 2014 w $\S$ 3 pkt 5a czytamy: „Jeżeli ocena działalności naukowej lub dydaktycznej [podkr. - A.S.] jest negatywna, to ocena łączna jest negatywna”.

19 Jako ekspert - pedagog, dydaktyk akademicki - zostałam zaproszona na jednej $z$ konferencji do dyskusji panelowej, której temat przewodni określono właśnie w następujący sposób: „Dydaktyka - piąte koło u wozu”.

${ }^{20}$ Przykładem jest publiczna wypowiedź o takim brzmieniu jednego $z$ dziekanów uniwersytetu utyskującego na obowiąek wprowadzony przez MNiSW kształcenia doktorantów w zakresie kompetencji dydaktycznych. Chodzi tu o inną osobę $z$ innego uniwersytetu niż w przyp. 4.

${ }^{21}$ Zob. http://ec.europa.eu/education/higher-education/doc/modernisation_en.pdf (21.01.2014). 
łach wyższych ${ }^{22}$. Jak podkreśla Teresa Bauman ${ }^{23}$, w Polsce dominuje przekonanie o tym, że nauczyciel akademicki nie musi posiadać żadnych formalnych, certyfikowanych kwalifikacji ani wiedzy na temat procesu kształcenia studentów poza tą, którą zna $z$ własnego doświadczenia. Świadczy to - zdaniem Autorki - o marginalizowaniu wartości dydaktyki szkoły wyższej oraz traktowaniu procesu kształcenia studentów jako mniej ważnego obszaru pracy zawodowej. Tymczasem proces kształcenia wymaga pewnych podstawowych, powiąanych $z$ dydaktyką ogólną umiejętności dydaktycznych. Pamiętać musimy jeszcze o specyfice kształcenia na poszczególnych kierunkach związanych $z$ tożsamością naukowa i dominującym paradygmatem metodologicznym danej dyscypliny. Inaczej przebiegać będzie proces kształcenia na filozofii, inaczej na biotechnologii, a jeszcze inaczej na kierunkach artystycznych koncentrujacych się np. na pracy $z$ ciałem. Dlatego nauczycielowi akademickiemu potrzebne są także kompetencje związane $z$ dydaktyką szczegółową osadzoną w specyfice danej dyscypliny.

Wprowadzenie KRK dla szkolnictwa wyższego zwróciło uwagę na niedoceniany obszar kształcenia zwiazany $z$ budowaniem kompetencji spolecznych studentów. Zadanie to wymaga od samych nauczycieli także pewnych kompetencji społecznych inter- i intrapersonalnych. W literaturze przedmiotu znajdujemy szereg propozycji opisu wymiarów profesjonalnych kompetencji nauczyciela akademickiego, które budują tzw. kompetencje dydaktyczne. Jednym $z$ ciekawszych ujęć jest wspomniana już propozycja Ingeborgi Stahr, która wyróżniła pięć obszarów budujących profesjonalne przygotowanie do nauczania: kompetencje dydaktyczne, metodyczne, społeczne, systemowe oraz osobowe ${ }^{24}$. Warto też w tym miejscu nadmienić, iż rola dydaktyka nie jest wcale jednorodna - co więcej, szereg zadań stawianych nauczycielowi akademickiemu może się wiązać ze swoistym „przeskakiwaniem” z jednego paradygmatu dydaktycznego do drugiego. Do wątku tego jeszcze powrócę.

${ }^{22}$ Zob. A. Sajdak, Paradygmaty ksztakcenia..., s. 192-196.

${ }^{23}$ Zob. T. Bauman, Dydaktyka szkoły wyższej, w: Encyklopedia pedagogiczna XXI wie$k u$, t. I, red. T. Pilch, Warszawa 2003, s. 810.

${ }^{24}$ Zob. A. Sajdak, Przygotowanie nauczycieli akademickich do prowadzenia zajęć dydaktycznych - możliwości wsparcia i przykłady dobrych praktyk, „Studia Oeconomica Posnaniensia" 2015 , vol. 3, no. 5, s. 7-27. 
Pogodzenie wszystkich wymagań roli - naukowca, dydaktyka i menedżera - jest bardzo trudne i może rodzić szereg frustracji. Franciszek Bereźnicki zwraca uwage, iż rola nauczyciela akademickiego i rola badacza pozostaja ze sobą w jawnym konflikcie. Nie można pogodzić dobrej pracy dydaktycznej $z$ dobra pracą naukowa, a „im więcej wysiłku wkłada młody nauczyciel akademicki w pracę dydaktyczno-wychowawcza, tym bardziej uświadamia sobie, że działa przeciw sobie - opóźnia swój rozwój naukowy, naraża na rotację"25. Badania pokazuja niejednoznaczny obraz, najczęściej jednak dowodzą, iż nadmierne obciążenie praca dydaktyczna i organizacyjna nie pozostaje bez wpływu na jakość pracy naukowej ${ }^{26}$. Można jednak znaleźć i takie deklarowane stanowiska - jak np. w badaniach Teresy Bauman ${ }^{27}-\mathrm{w}$ których nauczyciele twierdza, iż łączenie pracy zawodowej, naukowej $z$ dydaktyczna nie stanowi dla nich żadnego problemu. Autorka tłumaczy ten wynik, stawiając hipotezę, iż fakt ten jest wynikiem sztucznego oddzielenia sfery dydaktyki od sfery badań naukowych. Obowiązki dydaktyczne wypełniane i postrzegane sa najczęściej jako stabilne, rutynowe powtarzanie danej problematyki na zajęciach. A przecież nie na tym ma polegać kształcenie akademickie. Te zróżnicowane wyzwania roli zawodowej powoduja, iż nauczyciel akademicki często znajduje się w polu działania konfliktowych interesów, przeciwstawnych wymagań. Czasem żąda się od niego podejmowania działań i decyzji, które z punktu widzenia różnych interesów wydaja się opierać na całkowicie przeciwstawnych racjach, sprzecznych oczekiwaniach normatywnych.

Bycie naukowcem prowadzącym badania wymaga pewnego rodzaju egocentryzmu, nierozproszonego skupienia na pracy naukowej, a zatem wysiłku ukierunkowanego na spełnienie własnej potrzeby samorealizacji. Rola naukowca wymaga uruchomienia w sobie innych zasobów osobowych niż rola dydaktyka skoncentrowanego na możliwościach studen-

${ }^{25}$ F. Bereźnicki, Zagadnienia dydaktyki szkoły wyższej, Wyższa Szkoła Humanistyczna TWP w Szczecinie, Szczecin 2009, s. 122.

${ }^{26}$ Zob. np. E. Świerzbowska-Kowalik, Nauczyciele akademiccy i studenci, „Nauka i Szkolnictwo Wyższe” 1993, nr 1; E. Bochno, Sens i bezsens „bycia” adiunktem. Refleksje z perspektywy doktorów pedagogiki, w: Pedagogika. Zakorzenienie i transgresja, red. M. NowakDziemianowicz, P. Rudnicki, Wyd. Dolnośląskiej Szkoły Wyższej, Wrocław 2011.

27 Zob. T. Bauman, Uniwersytet wobec zmian społeczno-kulturowych, Wyd. UG, Gdańsk 2001, s. 88. 
tów, wspierającego ich rozwój w zakresie zdobywanej wiedzy, kształtowanych umiejętności oraz formowanych kompetencji społecznych. Zupełnie odmienny jest także „przepis roli” menedżera zarządzającego swoim rozwojem naukowym lub/i danym zespołem, pełniącego ważne dla społeczności uniwersyteckiej funkcje, zorientowanego na rynek i konkurencję w rywalizacji o punkty, granty czy miejsca w rankingach. Źródłem wielu dylematów nauczyciela akademickiego zwiąanych $z$ pełnieniem przez niego tak zróżnicowanej roli zawodowej jest również niespójność pomiędzy wymaganiami pracodawcy, czyli władz uczelni, a stosowanym przez niego systemem oceniania pracownika wyrażająca się zdaniem wypowiedzianym przez jednego $z$ rozżalonych adiunktów: „Czego innego się od nas wymaga, a za co inne rozlicza” ${ }^{28}$. W tym kontekście warto czekać na wyniki badań zespołu pracujacego pod kierunkiem Marii Dudzikowej dotyczących tzw. parametryzacji pracy nauczyciela akademickiego ${ }^{29}$.

\section{Ambiwalencja jako napięcie wynikające $z$ różnorodności i wzajemnej sprzeczności „,przepisu roli dydaktycznej” nauczyciela akademickiego}

Rola nauczyciela akademickiego dydaktyka także jest niejednolita i pełna wewnętrznych sprzeczności. Różnorodność form procesu kształcenia akademickiego, czyli prowadzenie wykładów, konwersatoriów, ćwiczeń, seminariów, warsztatów czy też tutorali oraz sprawowanie opieki nad indywidualnym planem i programem kształcenia (indywidualnym tokiem studiowania), stawia nauczyciela akademickiego w sytuacjach konieczności podejmowania działań wymagajacych uruchomienia w sobie innych, czasem przeciwstawnych zasobów. Ambiwalencja może być także rozważana jako napięcie wynikające $z$ różnorodności i wzajemnej sprzecz-

28 Rzecz dotyczyła ogromnego nakładu pracy koncepcyjnej, programowej i organizacyjnej zwiazanej z przebudowa programów kształcenia, która to nie znalazła swojego odzwierciedlenia w parametrycznej ocenie pracownika, a właściwie znalazła „odzwierciedlenie” w obniżonej ocenie rozwoju naukowego.

${ }^{29}$ Wstępne wyniki cząstkowych badań i zarysowanie pola tematycznego „Parametryzacja nauczyciela akademickiego w świetle arkuszy okresowej oceny na kierunkach pedagogicznych" zostały przedstawione przez M. Dudzikowa, K. Marszałek, S. Pasikowskiego na posiedzeniu KNP PAN z udziałem władz uczelni i wydziałów pedagogicznych WSE UAM Poznań, 9-10 czerwca 2014 r. 
ności roli nauczyciela akademickiego jako osoby zarówno nauczającej w tradycyjnym przekazie wiedzy gotowej - eksperta, jak i trenera stwarzającego okazje do samodzielnego uczenia się, niedyrektywnie wspierającego coacha czy wreszcie uczącego się razem $z$ innymi podmiotu. Ekspertowi o wysokich kwalifikacjach profesjonalnych, naukowych, znawcy danej dyscypliny powierza sie prowadzenie - niekiedy dla kilkusetosobowego audytorium - kanonicznych wykładów oraz ważnych konwersatoriów czy seminariów. Zadaniem eksperta jest zaprojektowanie kursu według standardów odzwierciedlających dorobek danej dyscypliny w określonym obszarze, przekazanie wiedzy oraz dokonanie kontroli przyswojenia przez studentów przekazanych lub/i zadanych lektura treści. Nawet jeśli nauczyciel akademicki ma bardziej nowoczesne przekonanie o samym procesie kształcenia, to konieczność przekazania obowiazkowej, fundamentalnej dla dalszego studiowania wiedzy „spycha” go w objęcia bardzo tradycyjnej dydaktyki. Nowoczesność może się wyrażać stosowaniem osiagnięć nowoczesnych technologii, ale konieczność rozliczenia kilkudziesięcioosobowej (a czasem nawet ponad stuosobowej) grupy studentów z przyswojenia danej wiedzy wymusza ograniczenie osobowego kontaktu i stosowanie egzaminów testowych. Ekspert przekazuje wiedzę i wymaga. Najczęściej osadzony jest w paradygmacie dydaktyki behawiorystycznej30 promującej pewność wiedzy obiektywnej, dominację metod podających oraz „obiektywne” metody kontroli. Rację mają ci, którzy twierdzą, że behawioryzm nie umarł wraz ze śmiercia swych założycieli, ale rozwija się i ewoluuje. Tradycyjne kształcenie uniwersyteckie tylko powiela i utrwala wypracowane w XIX wieku wzorce.

Nauczyciel akademicki pełni nie tylko rolę eksperta, ale również bywa trenerem prowadzacym ćwiczenia i warsztaty, na których studenci maja szansę zmierzyć się $z$ zadaniami problemowymi wymagającymi pracy indywidualnej i grupowej. Trener traktuje proces akademickiego kształcenia jako pewnego rodzaju „siłownię umysłowa” dla studentów pozwalająca im rozpoznać nie tylko ścieżki myślenia naukowego, ale i konstruować nowe modele, reprezentacje świata za pomocą dostępnych narzędzi kulturowych. Działania nauczyciela akademickiego-trenera ukierunko-

${ }^{30}$ Szerzej o dydaktyce akademickiej wpisanej w paradygmat behawiorystyczny zob. A. Sajdak, Paradygmaty ksztatcenia..., s. 307-343. 
wane sa na stwarzanie edukacyjnych okazji do samodzielnej aktywności studentów oraz uruchamianie w pracy grupowej wzorców społecznego uczenia się we współpracy. W pracy dydaktycznej wykorzystuje przede wszystkim różnego rodzaju metody aktywizujace, problemowe, modele badań grupowych i inne, konstytuowane przez paradygmat konstruktywistyczny (w odmianie psychologicznej lub społecznej) ${ }^{31}$. Aby jednak prowadzić zajęcia zgodnie $z$ osiągnięciami konstruktywizmu, konieczne jest odpowiednie przygotowanie.

Czasem zdarza się, że ten sam nauczyciel - ekspert i trener - wchodzi jeszcze w rolę wspierającego coacha. Prowadzenie seminariów dla małych grup, w których studenci sami określają kierunek własnych poszukiwań badawczych, czy też praca indywidualna metoda akademickiego tutoringu wymaga przeredefiniowania własnej roli zawodowej. Aby pracować ze studentem w modelu uczenia się $z$ doradca, trzeba czasowo zawiesić bycie zorientowanym na siebie i własny rozwój naukowcem, porzucić przywiązanie do kanonicznej wiedzy eksperckiej i ukierunkować aktywność na procesy wspierania rozwoju i realizację potencjału osoby uczącej się. Tu nauczyciel nie może być tym, który steruje, projektuje, sprawuje kontrolę, ale powinien wejść w rolę akceptującego, wykazujacego empatyczne zrozumienie, kongruentnego facylitatora. Powoli w świat uniwersyteckiego kształcenia wchodzi akademicki metoring, tutoring i coaching, które to formy podkreślaja, iż to sam student jest odpowiedzialny za własna naukę. Nauczyciel akademicki tutor-coach ma za zadanie udzielić pomocy i wsparcia studentowi w rozpoznaniu własnych możliwości i potrzeb edukacyjnych, w projektowaniu ścieżki rozwojowej oraz identyfikowaniu ewentualnych zagrożeń, w realizacji powziętych zamierzeń, a także w procesach ewaluacji i autoewaluacji osiagnięcia zamierzonych celów. Rola tutora czy coacha - wpisana w paradygmat dydaktyki humanistycznej ${ }^{32}$ - nie nadaje się do edukacji masowej opartej na globalnej konkurencji. Pojawia się jednak w akademickim kształceniu w różnorodnych formach opieki nad indywidualnymi ścieżkami studiów, pracach tutorskich czy doradztwie pedagogicznym.

${ }^{31}$ Szerzej o dydaktyce akademickiej wpisanej w paradygmat konstruktywistyczny zob. ibidem, s. 387-428.

${ }^{32}$ Szerzej o dydaktyce akademickiej wpisanej w paradygmat humanistyczny zob. ibidem, s. 344-386. 
Bywa również, że nauczyciel akademicki - ekspert, trener, coach wchodzi w rolę uczącego się podmiotu. Ta rola wymaga przyjęcia perspektywy krytyczno-emancypacyjnej ${ }^{33}$, zgodnie $z$ która celem akademickiego kształcenia jest pobudzanie myślenia krytycznego studentów oraz wspieranie procesów emancypacji wszystkich podmiotów edukacyjnych, czyli ukierunkowanie na wzrastanie autonomii i niezależności myślenia. To trudna rola, w której nauczyciel powinien mieć w sobie przyzwolenie na bunt, opór o niezależność intelektualną studentów, otwartość na różnorodność stanowisk i interpretacji wiedzy, gotowość do uwalniania się od dominacji i dogmatycznego myślenia oraz ukierunkowanie na konstruowanie i dekonstruowanie wiedzy. Tak konstytuowany proces kształcenia akademickiego nadaje relacji „nauczyciel-student” nową perspektywę. Zarówno nauczyciel, jak i student stają się uczacymi podmiotami, przy czym żaden $z$ nich nie dąży do pozycji dominującej - ani symbolicznie, ani intelektualnie. Rola ta również nie nadaje się do kształcenia masowego, ale sprawdza się $\mathrm{w}$ pracy seminaryjnej $z$ małymi grupami, zwłaszcza na studiach doktoranckich.

Czasami wyżej opisane role - eksperta, trenera, coacha czy uczącego się podmiotu - nie są tak ostro zaznaczone i zdają się rozpływać w rzeczywistości akademickiego dnia powszedniego. Różnorodność ról dydaktycznych, które pełni nauczyciel akademicki, może stać się swoistą wędrówka w poprzek poszczególnych paradygmatów. Chaos i splątanie paradygmatyczne ${ }^{34} z$ wiązane może być także $z$ aspektem rozwojowym $w$ stawaniu się, w byciu nauczycielem. Jak pokazują badania ${ }^{35}$, większość młodych ludzi rozpoczynajacych pracę w sposób naturalny poszukuje sprawdzonych wzorców metodycznych, które następnie jako pewne, stałe i skuteczne naśladuje i replikuje w pracy ze studentami. Poszukuja wiedzy pewnej, sprawdzonych algorytmów działań, skutecznej technologii kształcenia. Motywuja studentów do uczenia się, stosując niekiedy wyrafinowane strategie kar i nagród. Ich myślenie o procesie akademickiego kształcenia

33 Szerzej o dydaktyce akademickiej wpisanej w paradygmat krytyczno-emancypacyjny zob. ibidem, s. 429-468.

${ }^{34}$ O takim zjawisku w odniesieniu do dydaktyki szkolnej pisze D. Klus-Stańska, Dydaktyka wobec chaosu pojęć i zdarzeń, Żak, Warszawa 2010.

${ }^{35}$ Niepublikowane badania własne na grupie 148 doktorantów pełniacych obowiąki dydaktyczne. 
jest zbieżne $\mathrm{z}$ niemal wszystkimi dyrektywami dydaktyki behawiorystycznej. $Z$ kolei praca coacha czy tutora wymaga największego doświadczenia w kształceniu studentów, znajomości różnych ścieżek, możliwości, a przy tym wyjścia $z$ konwencji tradycyjnej dydaktyki. W każdej z ról nauczyciel musi uruchomić w sobie inne zasoby, przyjać inną perspektywę konstytuująca cele edukacyjne, wejść w określone relacje ze studentami, a także posłużyć się odmiennymi strategiami kształcenia. Role te wymagają różnych kompetencji i różnej dydaktyki. Tymczasem specyfika kształcenia akademickiego wymaga czasem umiejętności godzenia owych ról ze sobą. Wymaga umiejętności znoszenia napięć związanych $z$ doświadczaną ambiwalencją roli.

\section{Podsumowanie}

Świadomość ambiwalencji roli zawodowej może ułatwić radzenie sobie $z$ sytuacjami generującymi napięcia na różnorodnych poziomach pełnienia roli. Budowanie świadomości oznacza uruchomienie myślenia w kierunku rozpoznania różnorodnych oraz najczęściej sprzecznych ze sobą oczekiwań co do aktywności naukowej, dydaktycznej i organizacyjnej. Specyfika akademickiego kształcenia polega właśnie na tym, iż nauczyciel akademicki musi godzić przeciwstawne role, zaspokajać rozbieżne oczekiwania, co wymaga znoszenia napięć psychicznych związanych $\mathrm{z}$ pozostawaniem $\mathrm{w}$ polu przeciwstawnych sił. Wobec coraz większej złożoności współczesnego świata nie sposób uniknąć doświadczania ambiwalencji. To trudne, ale może stać się życiodajne. Jak twierdzi bowiem niemiecki badacz Joachim Freimuth, doświadczenie konfliktu roli może stać się źródłem uruchomienia procesów emancypacyjnych od Alma Mater postrzeganej jako matka karmiąca ${ }^{36}$. Ważne, by poświęcić chwilę refleksji na rozpoznanie obszarów sprzeczności wpisanych w rolę zawodowa, zadań i oczekiwań, które wymagają odmiennych sposobów funkcjonowania, odmiennego działania, uruchamiania w sobie różnorodnych zasobów osobowych. Świadomość ambiwalencji roli zawodowej może ułatwić nauczycielowi radzenie sobie $z$ sytuacjami generującymi na-

${ }^{36}$ Zob. J. Freimuth, Moderation in der Hochschule. Konzepte und Erfahrungen in der Hochachullehre und Hochschulenentwicklung, WindmühleVerlag, Hamburg 2000, s. 34-35. 
pięcia na różnorodnych poziomach pełnienia roli. Oprócz rozpoznawania samej roli zawodowej ważne jest także pogłębianie świadomości własnego funkcjonowania w roli, czyli krytyczne przyjrzenie się sobie samemu jako nauczycielowi oraz „otworzenie umysłu” na inne, alternatywne sposoby jej pełnienia.

Slowa kluczowe: nauczyciel akademicki, dydaktyk, ambiwalencja, rola zawodowa

\title{
ACADEMIC TEACHER- DILEMMAS, TENSIONS, ROLE AMBIVALENCE
}

\begin{abstract}
Summary
In the article the Author presents a thesis that a significant part of the dilemmas of an academic teacher - didactician are related to experiencing various types of ambivalence and tensions involved in this professional role. She addresses the category of ambivalence, considers its usefulness in the reflection upon the professional role, and presents two major areas in which tensions are experienced. Accordingly, she describes ambivalence as a tension caused by finding oneself in the field of opposing expectations and normative requirements concerning the professional role, established by the employer and finding their manifestation e.g. in the inconsistency of set tasks and the system of evaluation and promotion of an employee, that is, ambivalence inscribed in the triad of being a scientist, didactician and a certain type of manager all at the same time. Another presented area concerns the role ambivalence understood as a tension resulting from diversity and self-contradictory nature of a didactic role of an academic teacher, whose task is often to combine the roles of a teaching expert giving canonical lectures, a workshop trainer creating self-learning possibilities for students, an animator of shared experiences, or an empathic tutor supporting an individual path of development of a given person. Each of those roles requires the activation of different personal resources, different educational tools and different types of relations with students.
\end{abstract}

Keywords: academic teacher, didactician, ambivalence, professional role 



\section{DYSKUSJE, OPINIE}





\section{Jacek Moroz}

Uniwersytet Szczeciński

\section{Czy dialog sokratejski może być konstruktywistyczny?}

Metoda sokratejska stanowi bardzo interesujaca koncepcję dochodzenia do wiedzy. Zastosowana w edukacji zdecydowanie wpływa na zmianę względem dominującego w polskim szkolnictwie sposobu myślenia o celach, a także strategii organizowania pracy nauczyciela i uczniów na lekcji. Wobec powyższego metody tej nie można traktować jedynie jako „dodatku” podnoszącego atrakcyjność zajęć dydaktycznych. Nie jest to również jedna $z$ wielu ideologicznie neutralnych metod nauczania, która bez odpowiedniego światopoglądowego zaangażowania można wdrażać do znanej nam rzeczywistości edukacyjnej.

Ta starożytna orientacja na wiedzę, zwłaszcza w zestawieniu $z$ „behawioralnym ujęciem edukacji”, może wydawać się niezwykle nowatorska i rewolucyjna zarazem, szczególnie $z$ uwagi na coraz częstsze wśród teoretyków kształcenia nawoływania do zdecydowanego propagowania idei intelektualnego usamodzielnienia osoby uczącej się (co w praktyce szkolnej jest całkowicie ignorowane). O ile truizmem będzie twierdzenie, że dialog sokratejski jest niekompatybilny z tradycją behawiorystyczna, o tyle odrzucanie go $z$ podobnych pobudek, w ramach podejścia konstruktywistycznego, wcale nie wydaje się być takie oczywiste. Można wymienić co najmniej trzy powody, dla których metoda sokratejska, będacc głęboko zakorzeniona w klasycznej myśli europejskiej, z dydaktycznego punktu widzenia może stanowić atrakcyjna podstawę dla tworzenia nowoczesnego modelu kształcenia. Po pierwsze, dominuje w niej względna samodzielność w dochodzeniu do wiedzy tego, który ma ją zdobywać; po drugie, rola nauczyciela sprowadzona zostaje jedynie do swe go rodzaju pomocy, wspomagania i ukierunkowywania osoby uczacej się; ostatecznym - trzecim powodem jest procedura dochodzenia do wiedzy, która w ujęciu sokratejskim zyskuje zdecydowanie analityczny charakter. 
Dialog sokratejski może się przyczyniać do stworzenia specyficznej sytuacji uczenia się, gdzie trzy konstytuujące ją elementy - nauczyciel, uczeń i wiedza - tworza nierozerwalny układ relacji, w których pierwszoplanowa rolę zawsze odgrywa wiedza. Układ ów nie jest w żadnym razie zależny od samej metody stosowanej przez Sokratesa i to nie ona, co jest zasadnicze dla podjętego w artykule problemu, kształtuje sposób wzajemnych oddziaływań i uhierarchizowania elementów we wskazanej triadzie. Kluczowym elementem wpływający na sposób rozumienia i stosowania w praktyce edukacyjnej wspomnianej metody jest nie „techniczny jej wymiar", lecz bogate tło teoretyczne, bez którego dialog sokratejski traci swój właściwy sens.

A zatem dialog sokratejski $z$ technicznego punktu widzenia - potraktowany jako metoda wyabstrahowana $z$ całego teoretycznego kontekstu - dla konstruktywisty mógłby przedstawiać pewną praktyczną wartość. Niemniej jednak jako kategoria historycznie i filozoficznie uteoretyzowana w żadnym razie nie powinien być utożsamiany $z$ konstruktywizmem dydaktycznym. Wobec powyższego w niniejszym artykule będę się starał dowieść tezy, iż metoda wykorzystywana przez Sokratesa w procesie wspierania ucznia $\mathrm{w}$ dochodzeniu do wiedzy $z$ teoretycznego punktu widzenia nie powinna być „kojarzona” $z$ podejściem konstruktywistycznym. $Z$ uwagi na tak zakreślony projekt w tekście koncentruję się przede wszystkim na filozoficznych, a zarazem koniecznych z punktu widzenia dowodzonej tezy przesłankach omawianych koncepcji, świadomie pomijając szerszy pedagogiczny i psychologiczny - kontekst ich funkcjonowania.

\section{Czym jest metoda Sokratesa?}

Aby odpowiedzieć na pytanie tytułowe, w pierwszej kolejności należy nakreślić historyczno-filozoficzny kontekst powstania myśli sokratejskiej. Sokrates najprawdopodobniej nie był, jak donoszą badacze jego spuścizny, związany z żadna konkretna szkołą filozoficzna działająca za jego życia w Atenach. Stykał się on $z$ wieloma ówczesnymi filozofami, tj. $z$ reprezentantami jońskiej filozofii przyrody, znać miał również doktryny filozofii italskiej (eleatyzm i pitagoreizm) i tak mocno przez niego krytykowana filozofię sofistyczna. Niemniej jednak, jak twierdzi Irena Krońska, pomimo filozoficznego rozeznania i licznych filozoficznych kon- 
taktów nie miał Sokrates, jak wynika z przekazów platońskich, żadnego nauczyciela. Dialogi Platońskie przedstawiają Sokratesa jako zagorzałego przeciwnika myśli sofistycznej, równocześnie jednak zaświadczają o jego licznych kontaktach $z$ przedstawicielami tego kierunku. Okazuje się, że w Menonie o Prodikosie $z$ Keos Sokrates wyraża się jako o swoim nauczycielu, zaś w Teajtecie odsyła na nauki do niego tych, którym swoja „sztuka akuszerska” pomóc nie potrafi. W innych zaś pismach platońskich, tj. w Uczcie i Kratylosie, ten sam sofista potraktowany zostaje $z$ wyraźna dezaprobata ${ }^{1}$. Kwestia ta nie pozostaje bez znaczenia, albowiem Sokrates nie jest, jak mogłoby się wydawać, osobowością w pełni klarowną. Jest to postać, która przynajmniej w pewnej części uznać można za spełniajacy filozoficzna funkcję konstrukt Platona. Nie wchodzac w spory narosłe wokół tej kwestii, nie sposób oprzeć się wrażeniu, że mamy do czynienia z klasycznym i nierozstrzygalnym na bazie dostępnych studiów historyczno-literackich problemem filozoficznym. $Z$ naszego punktu widzenia nie sa to rzeczy nieistotne, ponieważ wskazuja na istotna lukę w wiedzy na temat pochodzenia filozofii sokratejskiej, a tym samym rozumieniu roli, jaka przy jej powstawaniu odegrał Platon.

Przyjrzyjmy się samej metodzie stosowanej przez Sokratesa. Tak zwany dialog sokratejski składał się $z$ metody majeutycznej i metody elenktycznej. Pierwsza - majeutyczna - przez samego Sokratesa porównywana była do sztuki położniczej technemaieutyke. Tę formę intelektualnego oddziaływania uznać można za metodę kształcenia, w której rola nauczyciela nie zostaje sprowadzona do ,zwykłego”, transmisyjnego przekazywania posiadanej przez niego wiedzy uczniowi. Obaj w pewnym sensie znajdują się w tym samym punkcie. Sokratejski nauczyciel nie może nauczać, ponieważ sam wiedzy nie posiada; jest on natomiast poszukiwaczem mądrości i powinnością jego jest oddawać się jedynie temu zajęciu ${ }^{2}$. Kształcenie w duchu sokratejskim służy zatem poszukiwaniu i dochodzeniu do prawdy, przy czym w obliczu tejże każdy nauczyciel uświadomić sobie powinien własną niewiedzę. Dopiero gdy po-

1 I. Krońska, Sokrates, Wiedza Powszechna, Warszawa 1964, s. 20-23.

2 W platońskim Menonie Sokrates wypowiada się tymi słowami: „Bo to nie tak, żebym ja sam miał dużo, a tylko drugich w biedę wprowadzał, tylko całkiem na pewno ja sam nic nie mam i przez to drugich też w biedę wciagam. Tak i teraz o tej dzielności - co to jest, ja sam nie wiem. A ty możeś przedtem wiedział, zanieś się ze mna zetknął, a teraz jesteś podobny do tego, co nie wie. Ale ja jednak chcę to razem $z$ tobą rozpatrzyć i szukać razem, co to jest". Platon, Menon, 79 E-80 D. 
siądzie cnotę wiedzy o niewiedzy, może oddać się zaszczepianiu jej w umysłach innych.

Metoda majeutyczna była sztuka, która miała „wydobywać z umysłów" uczniów to, co przez nich dotychczas nie było jeszcze uświadomione, miała ich wyrywać ze stanu niewiedzy. W efekcie jej zastosowania uczeń miał być w stanie „zrodzić wiedzę autentyczna”, niemniej jednak metoda majeutyczna pomagała jedynie tym, „w których duszach drzemie jakiś skarb i którzy w równym stopniu jego ucza [Sokratesa - przyp. J.M.], jak sami się uczą od niego"3.

Sztuka majeutyczna zatem stosowana była jedynie w stosunku do tych, którym dar taki Sokrates przypisywał. Pozostali byli poddawani innym rodzajom oddziaływania - ironii, metodzie elenktycznej (elenchos). Chociaż bylibyśmy skłonni ironię $e^{4}$ kwalifikować raczej jako postawę, to jednak uważa się $e^{5}$ że w wykonaniu Sokratesa zyskiwała ona status metody. Co istotne, sokratejska ironia nie miała wypływać $z$ wyrachowania, lecz $z$ autentycznej, niekłamanej i w pełni uświadamianej niewiedzy. Niemniej jednak sama ironia, niezależnie od tego, jak ja by sklasyfikować, polegała w praktyce na manipulacji rozmówca, zaś jej celem było wywołanie $\mathrm{w}$ nim wrażenia własnej niekompetencji. Zatem $z$ pełna premedytacja Sokrates utrwalał w swym interlokutorze przekonanie, że ten, będąc całkowitym laikiem w danej kwestii, powinien pokładać pełna ufność w jego (Sokratesa) wiedzy i profesjonalizmie. Giovani Reale ${ }^{6}$ uważa, że ironia stanowiła istotę metody sokratejskiej, będąc jego rdzeniem filozofowania. To ona służyła demaskowaniu pozornej wiedzy innych poprzez wyolbrzymianie do granic karykatury lub wykazywanie wewnętrznej sprzeczności stosowanych przez nich metod i głoszonych idei. Metoda elenktyczna miała charakter negatywny, za jej pomoca Sokrates dążyć ma do momentu, w którym jego rozmówca $z$ konieczności musiał się wycofać $z$ wcześniej żywionych przekonań. Niemniej jednak „zbijanie rozmówcy z tropu”, wy-

3 I. Krońska, Sokrates, s. 79.

4 Por. Platon, Państwo, I, 337a.

5 Por. I. Krońska, Sokrates, s. 79.

6 G. Reale, Historia filozofii starożytnej, t. I, tłum. E.I. Zieliński, Wyd. KUL, Lublin 2005, s. 375-376. 
kazywanie słabych stron jego rozumowania nie musiało się kończyć pozytywnym rozwiazaniem kwestii dyskutowanej7.

Cel Sokratesa może wydawać się szczytny - jest nim ukazanie słabości ludzkich możliwości intelektualnych, pozoru posiadanej wiedzy, a przez to złudzenia życia wartościowego. Najbardziej cenne jest to, co umyka wiedzy wyspecjalizowanej, o czym żadna konkretna umiejętność, żadna techne, choćby była to subtelna sztuka retoryki, nie przysporzy nam wiedzy (w rozumieniu episteme). Poszukiwania Sokratesa prowadza do cnoty, która jest wiedzą na temat życia godziwego. Dopiero taka wiedza doprowadzi do tego, co piękne, dobre i prawdziwe. Osiagnięcie tego pułapu myślenia zmienia perspektywę, w obliczu której to, co intelektualne - co tradycyjnie utożsamiane $z$ wiedza i poznaniem - nie musi być przeciwstawiane temu, co jest przedmiotem rozważań moralnych.

Ten moment prowadzi do intelektualizmu etycznego i racjonalizmu zarazem. Troska o duszę wiedzie do cnoty, do życia moralnego. Ten etap poznania byłby jednak niemożliwy bez episteme będacej przeciwieństwem doksy. Poznanie prawdy jest kluczem do życia dzielnego, do widzenia rzeczy takimi, jaki w rzeczywistości są. Sprawia to, iż każdy, kto posiadł wiedzę o dobru i złu, niejako z konieczności staje się etyczny, zawsze bowiem wybiera czyn dobry. A zatem dialog sokratejski niejako naturalnie musi przeistoczyć się w dyskusję o charakterze etycznym, jest to jego podstawowe zadanie. W zwiazku $z$ tym wykorzystywanie metody Sokratesa $z$ pominięciem jej ideologicznych przesłanek zmieniłoby sens i cel działania dialogicznego.

\section{Epistemologiczne podstawy edukacji konstruktywistycznej}

U podstaw konstruktywizmu leżą konkretne rozstrzygnięcia epistemologiczne powiazane $z$ problematyka dotyczaca rozumienia pojęcia „wiedzy”. Niemniej jednak koncepcja wiedzy to nie tylko warstwa rozważań epistemologicznych, lecz również określony kontekst ontologiczny, aksjologiczny, etyczny itp. Poniższe uwagi odnoszace się do kilku wybranych kwestii filozoficznych wyraźnie uwydatniają różnice, a nawet

7 Por. Platon, Dialogi, t. I-II, Antyk, Komorów 2005. 
zachodzące sprzeczności w obu - sokratejskim i konstruktywistycznym - podejściach.

Konstruktywizm radykalnie zrywa $z$ obiektywistyczna teoria poznania ${ }^{8}$, czego efektem jest całkowita zmiana rozumienia takich kategorii epistemologicznych, jak „prawda”, „wiedza”, „racjonalność” czy „uzasadnienie”. Wszystkie wymienione pojęcia nie sa już pozytywistycznie ugruntowane $\mathrm{w}$ tradycyjnym, korespondencyjnym języku, który dla konstruktywisty jest nie do przyjęcia. Niemniej jednak jego odrzucenie nie wynika z zamierzonej, programowej negacji wszystkiego, co zwiąane jest $z$ filozoficznym obiektywizmem - jest ono rezultatem aprobaty dla kryterium weryfikacyjno-koherencyjnego. Oznacza to, że każda teoria i każde twierdzenie, by zostać zaakceptowane, musi przejść przez gęste sito weryfikacyjne. Wobec powyższego koncepcja języka jako medium pomiędzy umysłem a transcendetnie pojętą rzeczywistością dla konstruktywisty zasługuje co najwyżej na miano metafizycznego postulatu bez szans na dobre uzasadnienie.

Konsekwencją takiego podejścia, tj. negacji tradycyjnej epistemologii, jest daleko posunięty relatywizm na wielu płaszczyznach. Wystarczy powiedzieć, że odrzucenie referencjalnej koncepcji języka niejako automatycznie wiąże się $z$ akceptacja relatywizmu pojęciowego, w ramach którego klasa obiektów O zależna będzie od systemu pojęciowego S. Oznacza to, $\mathrm{iz}$

system pojęciowy $\mathrm{S}_{1}$ będzie generował obiekty $\mathrm{O}_{1}$, analogicznie klasa obiektów $\mathrm{O}_{2}$ jest efektem obowiazywania systemu $\mathrm{S}_{2}$. Zgodnie $z$ tym relatywizmem ontologia jest implikowana przez dany system pojęciowy. Jednocześnie przyjmuje się założenie o niewspółmierności systemów pojęciowych $^{9}$.

Tego typu relatywizm pociaga za sobą względność wartości, w tym prawdy i wiedzy. W takim ujęciu wiedza, stanowiąc fundament obrazu otaczającego nas świata, zyskuje „chwiejny status” kulturowo wytwarzanych modeli rzeczywistości. Zaprzeczając reprezentatywnej roli języ-

8 Por. A. Zybertowicz, Poznanie i przemoc. Studium z nie-klasycznej socjologii wiedzy, Wyd. UMK, Toruń 1995.

9 J. Moroz, Dyskusja z relatywizmem prawdy $w$ Szkole Lwowsko-Warszawskiej, Scholar, Warszawa 20013, s. 20. 
ka, nie tylko zmieniamy treść pojęcia wiedzy, równocześnie godzimy się $z$ negacja koncepcji umysłu jako zwierciadła natury, uniwersalistycznie pojmowanych wartości etycznych, jak również idei rzeczywistości jako bytu samego w sobie. Tak radykalne sprzeniewierzenie się tradycyjnej epistemologii musi również rzutować na sposób rozumienia i uprawiania edukacji, której podstawowym celem staje się przygotowywanie ucznia do „jak najlepszego", skutecznego radzenia sobie z otaczajaca rzeczywistością. Edukacja zatem ma dostarczać i umożliwiać rozwijanie repertuaru konceptualnych narzędzi, dzięki którym uczeń zyskuje możność konstruowania modeli ${ }^{10}$, które następnie zweryfikuje w praktyce życiowej.

\section{Absolutyzm przeciw relatywizmowi}

Nie mam wątpliwości, że dialog sokratejski z dydaktycznego punktu widzenia stanowi ambitny i wymagajacy zarazem projekt pedagogiczny. Od nauczyciela oczekuje się określonych zdolności intelektualnych i niezachwianych przekonań, które zastosowane w odpowiednim edukacyjnym kontekście zawsze doprowadzą do spodziewanego rezultatu. Uczeń natomiast prócz umiejętności podjęcia i prowadzenia analitycznej dyskusji z nauczycielem musi wykazać się spora doza krytycznego myślenia, które „posiada moc znoszenia” racjonalnie nieugruntowanych przekonania. W tej kwestii można dopatrywać się zbieżności w obu omawianych tu podejściach do edukacji. Zarówno sokratyk, jak i konstruktywista wspierać będa samodzielność i krytycyzm w dochodzeniu do wiedzy, ograniczą do niezbędnego minimum rolę nauczyciela w procesie edukacji, zaś ocenę zdobytej wiedzy uniezależnią od kanonów nieusystematyzowanego myślenia. Na tym jednak podobieństwa się kończa. Deklamowany przez Sokratesa absolutyzm epistemologiczny powoduje, iż różnice w obu podejściach dotykaja kwestii fundamentalnych. Tym samym konstruktywistyczna epistemologia i wynikajacy z niej model edukacji nijak nie przystają do absolutystycznych oczekiwań sokratyków.

Należy pamiętać, że filozofia Sokratesa powstała jako ostry sprzeciw wobec „wielce szkodliwej” relatywistycznej ideologii sofistycznej, która

10 Częściowo na drodze indywidualnej aktywności poznawczej, lecz w większym zakresie - jeśli można się tak wyrazić - przy użyciu zastanych już kulturowych artefaktów. 
zwalczać można było właśnie przy użyciu racjonalnie ugruntowanego dialogu. Wynikajacy z niej kontekstowy obraz rzeczywistości miał lec w gruzach dzięki logice i rozumowi, którym obdarzone są wszystkie istoty ludzkie (choć nie wszystkie potrafią $z$ niego korzystać). Jak pisze Pierre Hadot:

Aby zawiązał się dialog, który doprowadzi jednostkę do [...] zdania sprawy $z$ siebie i ze swego życia, trzeba, by rozmówca Sokratesa na równi $z$ nim zgodził się podporządkować wymaganiom dyskursu racjonalnego albo raczej wymaganiom rozumu. Inaczej mówiąc, troska o siebie i zakwestionowanie siebie samego moga się zrodzić tylko w akcie przekroczenia jednostkowości, wzniesienia się na poziom uniwersalności reprezentowanej przez logos wspólny obydwu rozmówcom ${ }^{11}$.

Sokratejski dialog możliwy jest więc w sytuacji uznania istnienia wspólnego wszystkim ludziom logosu, jakiejś racjonalności, która w żadnym razie nie może być kulturowo uwarunkowana. Takiej uniwersalistycznie pojętej racjonalności nie znajdziemy nigdzie w epistemologii konstruktywistycznej. Wręcz przeciwnie, głosi się tam, iż „racjonalność” naszego myślenia i działania wynika właśnie $z$ kontekstu kulturowego, zaś ideał myślenia krytycznego można realizować dzięki niczym nieskrępowanej (mam tu na myśli uniwersalistycznie pojmowane założenia i apriorycznie przyjmowane zasady) aktywności intelektualnej nastawionej na realizację kontekstowo pojętych celów...

Na zakończenie przytoczę słowa Alana Blooma, w których niezwykle trafnie zostało odzwierciedlone myślenie sokratyków o edukacji:

Wolność oznacza dla człowieka zrzucenie okopów, czyli narzuconych przez społeczeństwo konwencji, opuszczenie jaskini i udanie się tam, gdzie słońce oświetla byty, dzięki czemu można ujrzeć je takimi, jakimi są. Kontemplacja oświetlonych bytów to zarazem wolność, prawda i najwyższa rozkosz. Metafora tą Sokrates pragnie pokazać, że wychodzimy od złudzeń czy też mitów, lecz możliwe jest zmierzanie do swiata poza konwencjami, czyli natury, za pomoca rozumu. Fałszywe mniemanie można skorygować, a do poszukiwania prawdy skłaniaja ludzi rozumnych wewnętrzne sprzeczności tych mniemań. Wychowa-

${ }^{11}$ P. Hadot, Czym jest filozofia starożytna?, tłum. P. Domański, Fundacja Aletheia, Warszawa 2000, s. 59-60. 
nie jest ruchem od ciemności do światła. Rozum rzutowany na byty,

o których początkowo tylko mniemamy w mroku, daje oświecenie ${ }^{12}$.

Po takiej deklaracji nie można mieć już złudzeń, iż konstruktywistyczny model edukacji wraz z zawartym w nim antyabsolutyzmem i kulturowo pojętym pragmatyzmem stanowi zaprzeczenie ideałów wychowania sokratejskiego.

Słowa kluczowe: metoda sokratejska, konstruktywizm, uczenie sie, dydaktyka, edukacja, epistemologia

\section{DOES SOCRATIC DIALOGUE CAN BE CONSTRUCTIVIST?}

\section{Summary}

Socratic method seems very interesting and attractive conception of the inquiry to knowledge. Teacher applying this method promote independence and self-reliance in the classroom, while his role is reduced to facilitate the learning process only. Besides, Socrates's method is based on definitely an analytical approach to knowledge.

In article I suggest that Socratic method, because of these characteristics, can be identified with constructivist approach to learning. At the same time I advance the thesis that mentioned method, as a historical and philosophical category, should not be confused with constructivism.

Keywords: Socratic method, constructivism, learning, didactics, education, epistemology

Translated by Jacek Moroz

12 A. Bloom, Umysł zamknięty. O tym, jak amerykańskie szkolnictwo wyższe zawiodło demokracje i zubożyło dusze dzisiejszych studentów, tłum. T. Bieroń, Zysk i S-ka, Poznań 2012, s. 345 . 



\section{Sylwia Jaskulska}

Uniwersytet im. Adama Mickiewicza w Poznaniu

\section{Pop-rytualne oblicze uniwersytetu}

Celem tekstu jest refleksja nad uniwersyteckimi pop-rytuałami, które moga być traktowane jako jeden $z$ elementów oblicza współczesnej uczelni wyższej. Rytuały czy też obrzędowość instytucji sa wyrazem jej kultury rozumianej jako zbiór dominujących w niej wartości, symboli, postaw, idei, wierzeń i obyczajów. W tekście analizuję obecne w ramach uniwersytetu zjawiska, które nazywam pop-rytuałami, analizy te poprzedzając wyjaśnieniem, co rozumiem pod pojęciem pop-rytualnego oblicza instytucji.

Dychotomiczny podział na kulturę wysoka i popularna był przez Pierre'a Bourdieu rozpatrywany w kategoriach relacji władzy i podporządkowania. Udział w określonej kulturze powiązany jest w tym ujęciu z przynależnością do danej klasy społecznej. Jak pisze, rekonstruujacc tę teorię Zbyszko Melosik, „w logice koncepcji Pierre'a Bourdieu ludzie pochodzacy $z$ wysoko stojacych w hierarchii klas społecznych i wykształceni będa preferować operę, muzykę poważna, książki Fiodora Dostojewskiego i dramaty Williama Szekspira, a także wizyty w muzeach i obiady we francuskich restauracjach [...]. Będą natomiast odrzucać możliwość udziału w takich praktykach kulturowych, jak: muzyka pop lub koncert grupy heavymetalowej, komiksy i popularne kryminały, przesiadywanie w pubach przy piwie i spożywanie hamburgerów i chipsów, a także telewizyjne reality show. $Z$ kolei ludzie pochodzący z niższych warstw społecznych będa $z$ ochota potwierdzać swój niski status udziałem w praktykach kulturo-

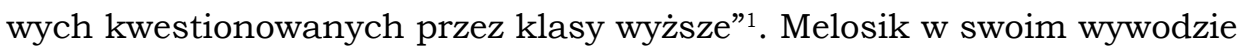
pokazuje nieaktualność tych tez. Sa płaszczyzny, w których następuje kulturowa deklasyfikacja (np. kultura popularna jest materia tworzenia

1 Z. Melosik, Kultura popularna i tożsamość młodzieży. W niewoli władzy i wolności, Impuls, Kraków 2013, s. 30. 
tożsamości młodzieży ze wszystkich warstw społecznych). Pojawiają się też nowe rodzaje uprzywilejowania kulturowego - osoby $z$ warstw wyższych nie tylko korzystaja $z$ kultury popularnej, ale też sa sprawniejsze w jej czytaniu, zatem robia z niej większy użytek, co zwrotnie wpływa na wzmacnianie się ich pozycji np. w grupach, w których funkcjonuja ${ }^{2}$.

Rozróżnienie na kulturę wysoka (właściwa inteligencji) i niską (specyficzną dla klasy średniej i robotniczej) przestaje więc obowiązywać, a tam, gdzie zachowały się podziały (np. elitarne, wymagajace dużych nakładów finansowych sporty), pojawiaja się substytuty dostępne także innym klasom. John Fiske zauważa, że szczególnie klasa średnia już od XIX wieku starała się kolonizować nisze kulturowe zarówno klasy wyższej, jak i niższej właśnie poprzez zastępowanie ekskluzywnych zajęć ich tańszymi podróbkami i przypisywanie wyższych wartości prymitywnym rozrywkom czy naśladowanie stylu nizin społecznych ${ }^{3}$. Melosik, pisząc o demokratyzacji smaków kulturowych ${ }^{4}$, zjawisko to nazywa, tłumacząc tę kategorię dosłownie $z$ języka angielskiego, „wszystkożernościa” klasy średniej. Ze względu na jej zróżnicowanie i elastyczność korzysta ona równie wprawnie z zasobów kultury wyższej, jak i popularnej5.

W koncepcji wszystkożerności nie zaprzecza się więc istnieniu czy znaczeniu stratyfikacji społecznej w zakresie preferowanych przez jednostki praktyk kulturowych. Twierdzi się natomiast, że ludzie $z$ wyższych klas społecznych mają „szersze” smaki, obejmujące zarówno wysoka, jak i średnią czy niską kulturę ${ }^{6}$.

Per analogiam można więc tłumaczyć obecność zjawisk kultury popularnej w murach uniwersytetów i akademii. Jeden $z$ ich kompleksów nazywam pop-rytuałami.

Związek rytuałów z kulturą rozumianą szeroko jako „ogół wytworów działalności ludzkiej, materialnych i niematerialnych, wartości i uznawanych sposobów postępowania, zobiektywizowanych i przyjętych w dowolnych zbiorowościach, przekazywanych innym zbiorowościom i następnym

2 Ibidem, s. 36.

3 J. Fiske, Zrozumieć kulture popularna, Wyd. UJ, Kraków 2010, s. 83.

4 Z. Melosik, Kultura popularna..., s. 40.

5 Ibidem, s. 37.

6 Ibidem, s. 38. 
pokoleniom" jest niewatpliwy. $Z$ jednej strony sa one w kulturze zanurzone, $z$ drugiej sa jej tkanka (kulturotwórcza rola rytuałów). Są one właściwe także kulturze popularnej. W dobie popkultury wielu fenomenom życia społecznego nadaje się przedrostek „pop-”, aby podkreślić ich nowe wymiary i znaczenia. Przywoływanego wyżej Melosika nazwać można polskim prekursorem tłumaczenia rzeczywistości społecznej przez pryzmat kategorii „pop” i ,instant”8. W swojej najnowszej książce autor pisze choćby o (pop) subkulturach młodzieżowych czy (pop)szczęściu ${ }^{9}$. Niektóre fenomeny edukacyjne również definiuje się jako pop czy instant - w literaturze pojawia się np. pop-dydaktyka (do kategorii tej powrócę w dalszej części tekstu) czy wychowanie instant ${ }^{10}$. Jarema Drozdowicz $z$ kolei wskazuje w ujęciu antropologicznym na obecność motywów związanych $z$ religia i religijnościa w popkulturowych refleksjach współczesności. Motywy te przenikaja do kultury popularnej i sa w niej powszechne. Sekularyzacja społeczeństw nie przeszkadza w żywotności symboli i odniesień religijnych w jednym $z$ dominujacych trendów kulturowych. Popkultura jest też podbudową dla wielu doktryn i ruchów religijnych. Jak pisze Drozdowicz

fenomen nowej religijności polega [...] na wytworzeniu nowego języka, który przemawia do ludzi w sposób bardziej bezpośredni, daje poczucie familiarności, niesie popularną symbolikę, a jednocześnie proponuje wartości dające namiastke transcendencji. Poprzez ten zabieg narracja religijnego dyskursu jest dziś zależna bezpośrednio od porząku popkultury, gdyż to ten porządek wyznacza kurs globalnego rozumienia, czym jest kultura jako taka. Powiazanie to jest odbierane przez wielu jako naturalna kolej rzeczy, a przynajmniej jako bardziej naturalne aniżeli anachroniczne teologiczne dysputy toczone za murami Watykanu ${ }^{11}$.

7 J. Szczepański, Elementarne pojęcia socjologii, PWN, Warszawa 1963, s. 47.

8 Por. np. Z. Melosik, Tożsamość młodzieży współczesnej (czyli jak żyć w kulturze typu „instant”), „Teraźniejszość - Człowiek - Edukacja” 2000, nr specjalny; idem, Kultura instant - paradoksy pop-tożsamości, w: Pedagogika u progu trzeciego tysiaclecia. Materiały pokonferencyjne, red. A. Nalaskowski, K. Rubacha, Wyd. UMK, Torun 2001.

9 Z. Melosik, Kultura popularna i tożsamość...

10 D. Klus-Stańska, Dydaktyka wokót chaosu pojęć i zdarzeń, Żak, Warszawa 2010, s. 82 i n.; S. Jaskulska, Wychowanie instant. Na przykładzie programu telewizyjnego „Superniania”, w: Kultura mediów, ciało i tożsamość - konteksty socjalizacyjne i edukacyjne, red. W. Jakubowski, S. Jaskulska, Impuls, Kraków 2011, s. 33 i n.

${ }^{11}$ J. Drozdowicz, Popreligia $w$ dobie popkultury, w: Ratio, religio, humanitas. Miscellanea dedykowane Profesorowi Zbigniewowi Drozdowiczowi, red. E. Jeliński, Z. Stachowski, S. Sztajer, Wyd. UAM, Poznań 2015, s. 308. 
Tomasz Szlendak zauważa, że

nowy model uczestnictwa w kulturze przekłada się na inne formy aktywności. Religijna jest pobudzana w podobny sposób. Weźmy przechodzenie przez Bramę Rybę nad Jeziorem Lednickim - przecież te kilkadziesiąt tysięcy osób uczestniczy w pewnego rodzaju evencie. Cała przestrzeń charytatywna, jeśli nie jest wpięta w jakieś megawydarzenie, też nie wzbudza większego zainteresowania ${ }^{12}$.

Według Szlendaka kulturę miesza się dziś z rozrywką. Kultura w tym rozumieniu to bycie z ludźmi w przestrzeniach, w których „coś się dzieje”. Kultura poza wydarzeniami festiwalowymi praktycznie przestaje istnieć. „Cała zmienia się w jedna wielka wielozmysłowa, widowiskowa, eventowa przestrzeń"13.

Wdzieranie się więc religii do kultury popularnej czy choćby otwieranie się na jej język i specyfikę (upraszczanie systemów wartości, komercjalizację, homogenizacja sposobów artykulacji, nastawienie na jednostkowe doświadczenie i tożsamość ${ }^{14}$ ) pozwala jej na trwanie, choć w zupełnie innej odsłonie i na inna niż kiedyś skalę, przy zachowaniu, przynajmniej w pewnym zakresie, dotychczasowych funkcji, które w innych warunkach mogłyby zaniknać.

Kryzys religii jako takiej wiąże się także z kryzysem obrzędowości. Rytuały religijne, podobnie jak sama religia, sa dziś w impasie. Mary Douglas zauważa, że o ile w społecznościach plemiennych niemal każde doświadczenie miało charakter religijny, więc oczywiste jest to, że i rytuały dotykały tej właśnie sfery, o tyle współcześnie „bardzo niewielka część naszych zachowań rytualnych rozgrywa się w kontekście religijnym"15. Religię zastępuje pop-religia, rytuały zaś pop-obrzędowość. Wyraźnie widać to na przykładzie rytuałów ślubnych. Przy słabnacym znaczeniu ceremonii zaślubin kwitnie biznes okołoślubny - samo przygotowywanie się do ślubu, targi ślubne, a potem wieczory panieńskie czy kawalerskie oraz

12 Maszyna do dzielenia. Co wynika z festiwalizacji naszej kultury. Rozmowa z Tomaszam Szlendakiem, http://m.wyborcza.pl/wyborcza/1,105406,16586967,Maszyna_do_ dzielenia_Co_wynika_z_festiwalizacji_naszej.html (7.05.2015).

\footnotetext{
13 Ibidem.

14 J. Drozdowicz, Popreligia..., s. 312.

${ }^{15}$ M. Douglas, Czystość i zmaza, PIW, Warszawa 2007, s. 106.
} 
podróże poślubne to nowe, przejmujące prym obrzędy i zwyczaje ${ }^{16}$. $Z$ jednej więc strony obserwujemy zanik obrzędowości, z drugiej zaś powstaja nowe fenomeny właściwe współczesności, w których można znaleźć cechy rytualne. Definiujac rytuał jako „wystylizowany i sformalizowany wzór zachowań”, Jack D. Eller pisze, że

wszystko, co jednostka - czy nawet bardziej społeczeństwo - wykonuje raz za razem w ten sam sposób, to rytuał. W tym sensie większa część kultury lub nawet cała kultura ma charakter obrzędowy czy zrytualizowany, ponieważ jej podstawa jest to, że ludzie znaja i robia „odpowiednie rzeczy" w odpowiednich sytuacjach społecznych ${ }^{17}$.

Pojawia się pytanie o to, w którym miejscu przebiega granica, tzn. co jest rytuałem, a co zdecydowanie nim nie jest. Czy bowiem codzienne zmywanie naczyń, robienie zakupów, gotowanie, czytanie dzieciom książek przed snem lub wspólne tańce na spotkaniu $z$ okazji urodzin u znajomych to rytuały? Czy wystarczy, żeby coś cechowała pewna rytmiczność i określony schemat postępowania (zmywanie naczyń), a może rytuały sa wpisane w każde święto, podczas którego pewna grupa ludzi robi to samo (taniec podczas spotkania urodzinowego)? Zapewne w dużej mierze odpowiedź zależy od tego, w świetle jakiej tradycji antropologicznej jej udzielimy, jakie założenia przyjmiemy. Poszukam więc rozwiązania przedstawionego dylematu, przybliżajac przyjęta przeze mnie definicję pojęcia „rytuał”.

Roy Rappaport wymienia kilka cech koniecznych, by jakieś zjawisko nazwać rytuałem: kodowanie przez osoby niebędace wykonawcami rytuału, formalność, niezmienność, wykonanie ${ }^{18}$. Po pierwsze więc, w rytuale odtwarza się elementy umocnione tradycją; wykonujący je nie sa ich autorami. Elementy te, o czym mówi druga $z$ wymienionych przez Rappaporta cech, sa powtarzane bardzo drobiazgowo, stereotypiczne i stylizowane ${ }^{19}$. Można mówić o stałym parametrach każdego rytuału, czyli

${ }^{16}$ S. Jaskulska, „Rytuał przejścia” jako kategoria analityczna. Przyczynek do dyskusji nad badaniem rytualnego oblicza rzeczywistości szkolnej, „Studia Edukacyjne” 2013, nr 26, s. 86 .

17 J.D. Eller, Antropologia kulturowa. Globalne sity, lokalne światy, Wyd. UJ, Kraków 2012, s. 353.

${ }^{18}$ R. Rappaport, Rytuał i religia w rozwoju ludzkości, Nomos, Kraków 2008, s. 62 i n.

${ }^{19}$ Ibidem, s. 64. 
o czasie (konkretna pora roku, dnia itp.), miejscu, podniosłej atmosferze. Rytuał w tym podobny jest do przedstawienia teatralnego, a tym różni się od gry, że wiadomo, jak się zacznie i jak zakończy - jest niezmienny (w pewnych granicach oczywiście) ${ }^{20}$. Rytuał musi być wykonywany, nie można zatem podtrzymywać rytuałów tylko w przekazie ustnym. Ronald L. Grimes pisze wręcz o żywotności rytuałów, które tylko wtórnie moga istnieć $\mathrm{w}$ tekstach, scenariuszach, opowieściach. Pierwotnie one dzieja się w trakcie odtwarzania ${ }^{21} . Z$ wykonaniem łączy się pojęcie ekspresji. $Z a$ Edmundem Leachem mówić można o rytuale właśnie jako o ekspresyjnym aspekcie zachowania. Eric W. Rothenbuhler przypisuje temu zachowaniu nadmiar estetyczny i nadmiar stylizacji (to wyróżnia rytuał spośród innych zachowań) $)^{22}$.

Rytuał nie ma według Rappaporta fizycznej mocy sprawczej, ale kieruje „na to, na co chce wpływać, czynniki i siły innego rodzaju”23. Skuteczność rytuału nie jest zatem widoczna i oczywista, ale nadprzyrodzona, tajemna, oparta na sile wywodzącej się ze słowa i z emocji. Obrzędy bywaja definiowane jako powtarzalne zachowania, którym towarzyszy przekonanie, że ich znaczenie wykracza poza wykonywane czynności ${ }^{24}$. Zachowania powtarzane rytualnie nie maja racjonalnych uzasadnień. Nie służą one realizacji celów, chodź te cele wskazuja. Przygotowywanie jakiegoś napoju, którego wypicie jest elementem obrzędu, nie ma więc na celu zaspokojenia pragnienia ludzi, którzy biora udział w rytuale. Napój jest symbolem czegoś, jego namacalność łączy świat zmysłowy z pozazmysłowym. Henri Hubert i Marcel Mauss w Zarysie ogólnej teorii magii odróżniaja skuteczność obrzędów od skuteczności mechanicznej właściwej technice, w odniesieniu do której „wytwory sa jednorodne ze środkami”"25.

20 S. Jaskulska, K. Motyl, Gra o Tron? Rytualy i gry w optyce teorii antropologicznej Clifforda Geertza i analizy transakcyjnej. Przyczynek do badania codzienności szkoły, „Studia Edukacyjne" 2014, nr 31, s. 76. s. 67 .

${ }^{21}$ R.L. Grimes, Beginnings in Ritual Studies, University of South Carolina Press 1994,

${ }^{22}$ E. Rothenbuhler, Komunikacja rytualna. Od rozmowy codziennej do ceremonii medialnej, Wyd. UJ, Kraków 2006, s. 36.

${ }^{23}$ R. Rappaport, Rytuat i religia..., s. 83.

${ }^{24}$ J.D. Eller, Antropologia kulturowa..., s. 353.

${ }^{25}$ M. Mauss, H. Hubert, Zarys ogólnej teorii magii, w: Socjologia i antropologia, red. M. Mauss, PWN, Warszawa 1973, s. 15. 
Żeby przygotować gorący napój, trzeba rozpalić ogień, postawić na ogniu garnek, wlać wodę itd. Wszystkie te czynności znaczą to, co znaczą. Skuteczność obrzędów jest swoista, bo „poszczególne akty rytualne oraz używane $\mathrm{w}$ nich środki sa zasadniczo niejednorodne $z$ celem osiaganym przez cały obrzęd - należą do odmiennych ciagów przyczynowo-skutkowych" ${ }^{26}$. Przygotowanie gorącego napoju nie będzie więc tu służyło celowi: zaspokojenie pragnienia, ogrzanie się itp., ponieważ sama mikstura ma nowe, rytualnie zakodowane znaczenie. Także rozpalanie ognia czy przelewanie napoju do odpowiednich naczyń może wykraczać poza te $z$ natury techniczne czynności. Ogień i naczynia moga być symbolami, elementami ciagu rytualnego.

Antropologowie podkreślaja społeczny charakter rytuałów. Jak pisze Bronisław Malinowski,

ceremonie towarzyszące narodzinom, rytuały inicjacji, dbałość o zmarłego, pogrzeb, akty żałoby i akty ku czci zmarłego, ofiary i rytuały totemiczne maja charakter publiczny i zbiorowy, często wpływają na plemię jako całość i pochłaniaja przez pewien czas cała jego energię ${ }^{27}$.

Rytuały w tradycyjnym, funkcjonalno-strukturalnym ujęciu służą podtrzymywaniu ciagłości społecznej. Rytuał, sam formalny i stały, jest „idealna reprezentacja ciagłości i trwałości”28, dlatego pierwotnie przypisywano mu rolę $\mathrm{w}$ podtrzymywaniu (przez potwierdzanie, oznajmianie, a nawet zaprowadzanie) społecznego status quo, analizowano go jako odbicie porządku społecznego. W tradycyjnych ujęciach rytuały postrzegane były jako element kultury podtrzymujący ciagłość społeczna, legitymizujacy władzę ${ }^{29}$.

Rytuał zatem to sformalizowane, stereotypiczne, powtarzalne czynności, które cechuja pewne stałe parametry, w tym stylizowana, przerysowana forma, a ich cele nie sa $z$ tego samego porzadku przyczynowo-skutkowego co sposób postępowania i środki. Czynności te muszą

${ }^{26}$ T. Jerzak-Gierszewska, Religia a magia. Klasyczne koncepcje antropologiczne, Wyd. Fundacji Humaniora, Poznań 1995, s. 107.

${ }^{27}$ B. Malinowski, Mit, magia, religia, PWN, Warszawa 1990, s. 408.

${ }^{28}$ Z. Mach, Rytuat, w: Encyklopedia socjologii, t. III, red. Z. Bokszański, A. Kojder, Oficyna Naukowa, Warszawa 2000, s. 355.

${ }^{29}$ Ch. Hann, Antropologia społeczna, Wyd. UJ, Kraków 2008, s. 178. 
być wykonywane przez grupę, służą przekazowi tradycji, podkreśleniu unikatowości danej wspólnoty, wyrażaja obowiąujące w niej zasady i dominujące wartości niekoniecznie powiązane $z$ religia. $W$ tę definicję nie wpisują się czynności dnia powszedniego, takie jak porządki domowe czy realizacja zadań zawodowych. Rytualnymi nazwać możemy za to ceremonie właściwe instytucjom edukacyjnym, np. absolutoria, pasowanie na pierwszoklasistę, apele, obchody świąt narodowych itp. Obrzędy tego typu wiążą się z pewną odświętnościa, są stylizowane, ich cele dotykaja pielęgnowania tradycji danej instytucji, przekazu obowiąujaccych w niej wartości, utrzymywania porządku, ukazywania związku ze społeczeństwem. Towarzyszą też przechodzeniu $z$ jednego statusu $\mathrm{w}$ następny (stawanie się uczniem danej szkoły, udzielanie absolutorium, czyli wyłączanie ze społeczności). Gdy w analizach zjawisk społecznych pojawia się termin „rytuał przejścia”, bo o nim mowa, zwykle przywoływane jest nazwisko Arnolda van Gennepa i jego rozumienie ich jako „sekwencji obrzędowych, które towarzysza przechodzeniu z jednego stanu do innego, $z$ jednego świata (w ujęciu kosmicznym lub społecznym) do drugiego"30. Van Gennep w swojej trójfazowej teorii obrzędów przejścia objaśnia je na tyle uniwersalnie, że inne definicje narastaja na niej, a niektórzy autorzy odsłaniaja czy oświetlaja te aspekty, które z różnych powodów van Gennep pominął. Uczynił to np. przywoływany wcześniej Bourdieu.

Badacz ten dostrzegł ciemną stronę obrzędów przejścia, nazywając je z punktu widzenia socjologii władzy rytuałami mianowania ${ }^{31}$. Pokazał, że ich istota jest oddzielanie jednych grup od drugich. Ważne jest oczywiście, co dzieje się $z$ osobami podlegającymi procesom przejścia, ale równie ważna jest grupa, która im nie podlega. Zwykle dlatego, że $z$ jakichśs powodów nie może (nie spełnia kryteriów, ktoś jej do obrzędu nie dopuszcza itp.) ${ }^{32}$. To swoisty program ukryty obrzędów przejścia. Na przykład w przypadku męskich obrzędów inicjacyjnych nie chodzi tylko o wchodzenie chłopca do świata mężczyzn, ale też o stawianie wyraźnej granicy między światem kobiet i mężczyzn (do którego dziewczęta nie mają wstępu). Inicjować

\footnotetext{
${ }^{30}$ A. van Gennep, Obrzędy przejścia. Systematyczne studium ceremonii, PIW, Warszawa 2006 , s. 37.

${ }^{31}$ M. Segalen, Obrzędy i rytuały współczesne, Verbinum, Warszawa 2009, s. 47.

32 P. Bourdieu, Les rites commeactes d'instytution, „Actes de la Rechercheen Sciences Sociales" 1982, vol. 43, s. 58.
} 
w tym przypadku to znaczy sankcjonować i zatwierdzać stan rzeczy, ustalony porzadek, dokładnie ustanawiać w sensie prawno-politycznym ${ }^{33}$. Bourdieu nie skupia się więc, jak robi to van Gennep, na samej formie, na trwaniu w czasie obrzędów, na ich procesualnym charakterze. Interesuja go w tej sytuacji ludzie: mianowani i mianujacy, jako grupa uprzywilejowana $w$ relacji $z$ przedstawicielami władzy (przejście do nowego statusu na konkretnych zasadach, zgodne $z$ dyspozycjami rządzących), oraz ci, którzy nie mają możliwości wziąć udziału w rytuale ${ }^{34}$.

Obrzędami mianowania można nazwać interesujące mnie w tym tekście ceremonie majace miejsce w instytucjach edukacyjnych (pasowanie na ucznia, absolutoria itp.). Rytualnie dopuszcza się np. kogoś do bycia członkiem danej społeczności szkolnej. Służa temu szczególnie egzaminy na zakończenie jednego etapu edukacji lub rozpoczęcia kolejnego, a przynajmniej tak postrzega je Bourdieu ${ }^{35}$. Formalnie potwierdzeniem przemiany sa świadectwa, dyplomy, oceny, a brak promocji do klasy programowo wyższej jest dosłownym „zakazem przemiany”, zatrzymanym $\mathrm{w}$ trakcie trwania rytuałem przejścia. Proces ten przenosi się również w sferę nieformalna - w wielu szkołach (a także bractwach studenckich, szkolnych drużynach sportowych itp.) społeczność uczniowska urządza nowo przyjętym uczniom „chrzest”, który przyrównywany może być do „fali” w wojsku ${ }^{36}$. Można więc stać się formalnie uczniem czy studentem, jednak nieformalnie nie być członkiem wspólnoty, jeśli ktoś nie podoła wyzwaniom nieformalnej inicjacji.

Szczególnym przykładem obrzędów mianowania są rozmaite konkursy. Ich zwycięzcy sa dopuszczeni do pewnych przywilejów, które innym sa niedostępne. W szkole może być to np. częsta praktyka wiązania wzorowej oceny zachowania $z$ faktem bycia laureatem olimpiad przed-

33 A.K. Choińska, Rytuały świętowania w ujęciu Pierre'a Bourdieu, „Kultura i Społeczeństwo" 2012, nr 4, s. 29.

34 M. Segalen, Obrzędy i rytuały..., s. 49.

35 P. Bourdieu, Les rites...

${ }^{36}$ Por. J. Johnson, Through the Liminal: A Comparative Analysis of Communitas And rites of Passage in Sport Hazing and Initiations, "Canadian Journal of Sociology” 2011, vol. 36 , no. 3 . 
miotowych ${ }^{37}$. Następstwem etykiety laureata konkursów sa pewne prawa i obowiązki - tej grupie zwykle stawia się wyższe wymagania. Ktoś, kto wygrał konkurs, czuje się zobowiązany sprostać statusowi, który tym samym otrzymał ${ }^{38}$. Można też powiedzieć o pewnej kondensacji rytualnego mianowania, kiedy odbywa się ono na drodze konkursu, castingu, eliminacji, rekrutacji. Obrzędy przejścia sa szczególnie wyraziste wtedy, gdy nie tylko oddzielaja jedna grupę od drugiej, ale też jedna $z$ tych grup jest nieliczna ze względu na spełnianie bardzo rygorystycznych kryteriów (absolwenci prestiżowych uczelni, dyrektorzy największych firm, zwycięscy konkursów). W grze o wysoką stawkę bogata jest też forma obrzędowa. Wystarczy przyjrzeć się ceremoniom wręczania różnych wyróżnień przez głowy państw, otwarciom i zakończeniom ważnych imprez sportowych, obrzędowości elitarnych zgromadzeń. W takich momentach uwidacznia się status jednostek. Jak za Randallem Collinsem zauważa Melosik, dzieje się tak w sytuacjach formalnych, wysoce zrytualizowanych ${ }^{39}$. Rytualizacja i ograniczony dostęp sa w swoistym sprzężeniu zwrotnym - najbardziej zrytualizowane sa najbardziej elitarne przestrzenie społeczne, np. dwory arystokratyczne czy choćby, w skali uniwersytetów, rady wydziałów, a do czynności rytualnych nie każdy ma dostęp.

Chciałabym skupić się na konkursach, które są organizowane w ramach wyższych uczelni w Polsce, a konkretnie na szczególnym ich rodzaju, bo na tych, które nie testują wiedzy. Nie chodzi mi więc o rywalizację związaną z przedmiotem studiów, ale o różnego rodzaju plebiscyty sympatii, wybory miss i mistera itp. Konkursy tego typu od jakiegoś czasu pojawiaja się w murach uczelni, stają się więc elementem kultury instytucji, do której zdaja się zupełnie nie przystawiać. Sa jednak do niej przeszczepiane. Wzbudzaja pewne emocje i dyskusje, ale powoli sa wchłaniane i być może wkrótce nikogo już nie będą dziwić. Oto kilka przykładów.

${ }^{37}$ S. Jaskulska, Ocena zachowania $w$ doświadczeniach uczniów, Wyd. UAM, Poznań 2009, s. 19.

${ }^{38}$ M. Segalen, Obrzędy i rytuały..., s. 48.

${ }^{39}$ Z. Melosik, Kultura popularna i tożsamość..., s. 49. 
Wybory miss uniwersytetu. Coraz częściej uczelnie wyższe organizuja wybory miss ${ }^{40} . Z$ dostępnych $\mathrm{w}$ internecie relacji filmowych ${ }^{41} \mathrm{z}$ ich przebiegu wynika, że w niczym nie odbiegają one od innych wyborów królowej piękności. Studentki nie tylko opowiadają więc o sobie, o swoich zainteresowaniach i planach na przyszłość, ale też przechadzają się po wybiegu w kostiumach kapielowych. Jakiś czas temu wokół tego typu konkursu organizowanego w Uniwersytecie Mikołaja Kopernika w Toruniu przetoczyła się goraca dyskusja $z$ organizacjami feministycznymi w jednej z głównych ról. Na stronie „Codziennika Feministycznego” znalazło się oświadczenie, w którym czytamy, że poprzez takie praktyki uczelnie wyższe promują drogę kariery przez cielesność. „Jest to dla kobiet dość jasny komunikat - możesz się uczyć, ale za pomoca ciała szybciej osiagniesz sukces"42. Także grupa studentów UMK zgłaszała sprzeciw, protest swój argumentując tym, że „konkursy piękności nie powinny odbywać się na Uniwersytecie. Uczelnia nie jest miejscem, w którym należałoby oceniać walory ciała w opiętym stroju kapielowym, ale wiedzę, inteligencję i pracowitość”33. Jak wynika $z$ relacji $z$ całej sprawy zamieszczonej na portalu gazeta.p $1^{44}$, rzecznik UMK uznał, że w konkursie organizowanym za zgoda władz rektorskich (jeden $z$ prorektorów zasiada nawet $\mathrm{w}$ jury) nie ma nic złego. Zarzuty formułowane pod adresem organizatorów to, według rzecznika

pewien głos w szerszej dyskusji o roli kobiet we współczesnym świecie. Podchodzimy do tego $\mathrm{z}$ szacunkiem, ale tam nie dzieje się nic, co wymagałoby interwencji władz rektorskich. Nigdy nie dochodziły do nas głosy, że dzieje się tam coś nieprzyzwoitego.

${ }^{40} \mathrm{Na}$ przykład https://www.facebook.com/pages/Wybory-Miss-Uniwersytetu-Medycznego-w-\%C5\%81odzi/273439446052039 (wybory Miss Uniwersytetu Medycznego w Łodzi); https://www.facebook.com/pages/Wybory-Miss=-AWF155510684477031/?frefts (wybory Miss AWF w Warszawie) (7.05.2015).

${ }^{41}$ Na przykład https://www.youtube.com/watch?v=FgDuM4r4xBE (wybory Miss Uniwersytetu Medycznego w Łodzi); https://www.youtube.com/watch?v=_GN5_e_TE4U (wybory Miss Uniwersytetu Medycznego w Łodzi); https://www.youtube.com/watch?v=kGAMHdyVYIs (wybory Miss Uniwersytetu Opolskiego) (7.05.2015).

${ }^{42} \mathrm{http}$ : / / codziennikfeministyczny.pl/oswiadczenie-ws-konkursu-na-umk/ (7.05.2015).

${ }^{43}$ https:// niedlamissumk.wordpress.com/ (7.05.2015).

${ }^{44} \mathrm{http}: / /$ wiadomosci.gazeta.pl/wiadomosci/1,114871,15355336,Protest_przeciwko_ wyborom_Miss_UMK__Faktycznie_sa.html (7.05.2015). 
Rzecznik nie zgodził się też $z$ argumentem, że uniwersytet nie jest miejscem odpowiednim dla konkursów piękności, mówiąc, że

Uniwersytet nie jest miejscem, w którym powinny się odbywać działania wyłącznie edukacyjne. Wręcz zachęcamy studentów, żeby organizowali sobie życie w ramach uczelni, mając poczucie, że to nie będa tylko wykłady. Każde władze uniwersyteckie się ciesza, gdy studenci wykazują jakąs aktywność. Jaka ona jest, taka jest. Pewnie, że fajniej by było, jakby powstawały same studenckie teatry dramatyczne. Taka mamy kondycję kulturalną społeczeństwa i jeśli młodzież to bawi, nie należy tego zabraniać.

Wybory superstudenta, wybory najmilszej studentki. Podobne pytania o to, na ile powaga uniwersytetu licuje $z$ pewnego rodzaju imprezami, oraz o to, jaka jest rola uczelni wyższych w zwalczaniu/wzmacnianiu stereotypów płci, dotycza innego rodzaju konkursu. Sa to zawody, których stawka jest tytuł najsympatyczniejszego studenta. One też staja się elementem studenckiej kultury. W czasie, gdy piszę ten tekst, w Krakowie odbywaja się wybory najmilszej studentki ${ }^{45}$ i superstudenta ${ }^{46}$. Poszczególne uczelnie ogłosiły castingi, w wyniku których zostali wyłonieni kandydaci. W ramach Juwenaliów zaś będzie miał miejsce wielki finał, podczas którego jeden student i jedna studentka staną się właścicielami zaszczytnych tytułów.

Co kryje się pod hasłami „superstudent” i „najmilsza studentka”? Organizatorzy tak reklamuję na Facebooku swoją imprezę: „Jeśli masz ciekawa pasję i potrafisz nią zarazić innych, znajomi uważają Cię za czarująca i błyskotliwą osobę i nie boisz się publicznych wystapień, to koniecznie zajrzyj do wydarzenia"47. Wygląda na to, że tego samego wymaga się do kandydatów na superstudenta i na najmilszą studentkę. Piętnujące kobiety rozróżnienie w warstwie językowej na „najmilsza” studentkę $i$ „super” studenta pozostaje. Na facebookowym profilu Uniwersytetu Ja-

\footnotetext{
${ }^{45}$ https://www.facebook.com/events/1422057198100139/ (7.05.2015).

46 https://www.facebook.com/events/1586162258298979/ (7.05.2015).

${ }^{47}$ https://www.facebook.com/jagiellonian.university/photos/a.397046157472.1652 $53.311279977472 / 10152808713667473 /$ ?type $=1 \&$ fref $=$ nf $(7.05 .2015)$.
} 
giellońskiego ${ }^{48}$ widnieja m.in. takie komentarze do wydarzenia, jakim jest casting na najmilszą studentkę i superstudenta tego uniwersytetu:

SuperStudent i Najmilsza Studentka? Proponuję się zastanowić nad stereotypowościa takich tytułów. To kompromitujące, że UJ organizuje imprezę świadcząca o kompletnym braku świadomości kulturowej. Może jeszcze do kompletu konkurs na najlepszego pana profesora i najmilsza pania profesor? Litości.

Czy naprawdę nikomu nie przeszkadza, że mężczyźni startuja w kategorii „super”, a kobiety - „miła”.

Oczywiście, że przeszkadza, bulwersuje i mierzi.

Kategorie, które nawet przedszkolu nie przystoja.

Rozumiem, że to zabawa, ale nie może to być argument usprawiedliwiający niestosowność przyznawanych tytułów. Czemu nie można bawić się w wybory na Super Studentkę? Ja, jako studentka i kobieta, wolałabym być postrzegana przez pryzmat swoich osiagnięć i innych wartości, które sobą reprezentuję (poza byciem „miłą).

Chłopcy moga być fajni i mądrzy, a dziewczęta tylko miłe i ładne. Czy to jakiś żart??? Promocja seksizmu???.

Najmilszy wykładowca. W podobnych plebiscytach sympatii na niektórych uczelniach oceniani sa nie tylko studenci, ale też wykładowcy. Na przykład na Wydziale Prawa i Administracji UWM w Olsztynie kilka lat $z$ rzędu odbywał się plebiscyt Laury Cezara ${ }^{49}$. Społeczność akademicka wybierała zwycięzców w wielu kategoriach, np. najsympatyczniejszy student, najsympatyczniejszy wykładowca, ulubieniec studentów i pracowników ${ }^{50}$. Osoby, które stawały do konkursu w kategorii najsympatyczniejszy wykładowca, musiały dokończyć kilka zdań takich samych dla wszystkich kandydatów. Cytuję wybrane rozwinięcia zdań: „Pracuję na WPiA, ponieważ...”, „Według mnie studenci lubia moje zajęcia, ponieważ..." zebrane na stronie internetowej konkursu ${ }^{51}$ :

48 https://www.facebook.com/jagiellonian.university/photos/a.397046157472.1652 $53.311279977472 / 10152808713667473 /$ ?type=1\&fref=nf\&pnref=story (7.05.2015).

49 https://sites.google.com/site/laurycezara/ (7.05.2015).

50 „Ulubieniec” to kategoria, w której w szranki stawali pracownicy administracyjni. Podobnie jak w przypadku konkursu na najsympatyczniejszą studentkę i superstudenta zastanawia nazewnictwo, które może być uznane za przemocowe (inne sa konotacje słowa „sympatyczny”, a inne „ulubieniec”).

${ }^{51} \mathrm{https}$ /// sites.google.com/site/laurycezara/najsympatyczniejszy-wykladowca (7.05.2015). 


\section{Pracuję na WPiA, ponieważ...}

Sprawia mi to dużą przyjemność.

...ponieważ (wydaje mi się, że) jest to jedyne miejsce, gdzie - przy dobrej chęci drugiej strony - mogę komuś pomóc przynajmniej z niektórymi problemami w życiu.

Lubię.

Bardzo lubię swoja pracę, co semestr zastanawiam się jak tu urozmaicić studentom zajęcia: wymyślam ćwiczenia i przykłady. Lubię też pracę stricte naukowa - pośród monografii i periodyków $z$ filiżanką dobrej kawy mogę siedzieć pół nocy.

\section{Według mnie studenci lubią moje zajęcia, ponieważ...}

Staram się przekazywać wiedzę w sposób jasny i zrozumiały.

Gdyż po prostu nie przynudzam. A przynajmniej staram się nie przynudzać. A jeśli, już któryś zaśnie $z$ nudów, to staram się go nie budzić.

Sam bardzo niedawno zajmowałem miejsce w ławce a nie za biurkiem, o czym staram się nie zapominać.

Może... bezpośredniość wypowiedzi i szczerość granicząca $z$ brakiem poprawności politycznej. Może...

Sa wspaniałe.

Odpowiedź na tak postawione pytanie jest prosta: staram się być normalna osoba, która nigdy nie pokazuje swojej ogromnej wiedzy, traktuję Studenta $z$ szacunkiem. Dla mnie to Student jest najważniejszy. Moim obowiązkiem jest zrobić wszystko co możliwe, aby wiedza która przekazuję była zrozumiała dla Studenta. Każdy Student ma możliwość kontaktu $z$ moją osobą nie tylko w trakcie zajęć i na dyżurze, ale również ma ze mną kontakt telefoniczny i mailowy. W niemal każdej, chwili jestem do dyspozycji Studentów nie tylko w momencie zaliczenia przedmiotu, ale i w innych sytuacjach w jakich Student się znalazł, a ja mogę mu pomóc. Nigdy też nie zamykam Studentowi drogi do jak najwyższej oceny, staram się przekazywać wiedzę w sposób jak najbardziej zrozumiały okraszając ją ogromną liczba przykładów.

mówię: pozachwycajmy się prawem wyznaniowym :)

Nie wiem czy lubią zajęcia, ale chyba lubia mnie, skoro tu trafiłam ;)

Podobno studenci lubia moje zajęcia bo jestem sprawiedliwa. Nie wiem czy sama bym się tak oceniła, ale staram się spełnić dane obietnice. No i pilnuję żeby nie zasypiali - na szczęście Bozia dała mi donośny głos i pokłady energii która staram się zarażać.

W pytaniu zawarta jest ocena, czy na nią zasługuję? O tym zadecyduja sami zainteresowani. $Z$ pewnościa jednak studenci w niczym mi nie przeszkadzają. Lubię swoją pracę, a więc nie muszę się nad nimi znęcać:-)

...czasem uda mi się ich przekonać, że wbrew pozorom zależy im na tym samym na czym zależy mnie jako wykładowcy. Poza tym obie 
strony zainteresowane sa ciekawym i praktycznym podejściem do nauki. Można również dodać, że czasem na moich zajęciach oprócz pracy dydaktycznej można się uśmiać do łez :)

Z wypowiedzi tych przebija dość powszechnie podzielany przez kandydatów pogląd, że wykładowca powinien być energiczny, mieć poczucie humoru, powinien lubić studentów i zapewniać im hedonistyczne doznania. Na pewno zaś nie powinien „przynudzać”. Preferowany jest więc sposób uprawiania zawodu nauczyciela akademickiego, który można nazwać pop-dydaktyką. Pop-dydaktykę za Dorota Klus-Stańską definiuję jako wiązanie procesów dydaktycznych przede wszystkim $z$ takimi ich atrybutami, jak „przyjemne doznania emocjonalne, rekreacyjność i interpersonalne ciepło"52. Wiedza profesjonalna z zakresu metod nauczania ustępuje wiedzy potocznej, w której dominuje sentymentalizacja psychologii humanistycznej. Tak uprawiana pop-dydaktykę można nazwać też dydaktyka terapeutyczną.

W tym myśleniu o nauczaniu przecenia się znaczenie uczestnictwa w procesie zdobywania wiedzy. Najlepiej, aby to uczestnictwo było lekkie, łatwe i przyjemne, w atmosferze zabawy.

Pop-dydaktyka to

sposób myślenia i działania, dla którego jest charakterystyczne zastępowanie pojęć i argumentów odnoszących się do procedur opracowywania wiedzy przez pojęcia i argumenty opisujace emocje, klimat interpersonalny i cechy osobowości przy jednoczesnym nadawaniu im znaczeń sentymentalnych, lekkich w odbiorze, bliskich ludyczności, powierzchownych, swojskich ${ }^{53}$.

Można więc powiedzieć, że (skoro wykładowców o takich właśnie poglądach zgłaszali studenci do konkursu) w tym pop-rytualnym obrzędzie mianowania premiuje się osoby, które uprawiaja pop-dydaktykę.

Ceremonie, które opisałam, pełnia podobne funkcje jak rytuały rozumiane tradycyjnie, a więc służa podtrzymywaniu, pielęgnowaniu i umacnianiu społeczności. Tak np. opisano na jednym $z$ portali internetowych

52 D. Klus-Stańska, Dydaktyka wobec chaosu..., s. 82.

53 Ibidem, s. 95. 
Juwenalia, podczas których wręczone zostaną nagrody dla superstudenta i najmilszej studentki Krakowa:

Juwenalia Krakowskie nie bez przyczyny nazywamy Wielkim Świętem Studentów. W ciagu sześciu dni nieustającej zabawy żacy wybiora Najmilszą Studentkę i SuperStudenta Krakowa oraz przemaszeruja 18 maja w barwnym korowodzie na Rynek Główny, by tam otrzymać od Prezydenta Miasta symboliczne klucze do bram Grodu Kaka. Juwenaliowy tydzień wypełnia koncerty, tańce pod scena i wspólny śpiew ${ }^{54}$.

Tego typu imprezy na pewno służą budowaniu wspólnoty studenckiej. Jednocześnie ten kulturowy miszmasz, w którym studentka prezentujaca na scenie konkursu taniec brzucha następnie przez kilka dni jest w posiadaniu kluczy do bram miasta, gdy w jury konkursów piękności zasiadaja rektorzy, a wykładowcy zamieszczają na portalach konkursów uniwersyteckich swoje zdjęcia w sytuacjach prywatnych, nadal wywołuje pewne głosy sprzeciwu. Świadczą o tym internetowe komentarze wokół tego typu eventów oraz odmowa udziału (na stronie konkursu Laury Cezara jest długa lista wykładowców, którzy nie przyjęli studenckiej nominacji w kategorii najsympatyczniejszy wykładowca, co być może jest jaką́s forma sprzeciwu). Znaczacym przykładem może być fakt, że gdy studenci wystosowali do rektora UMK list w sprawie wyborów miss, ich protest poparło kilkudziesięciu wykładowców ${ }^{55}$. Protestują więc niektórzy studenci, niektórzy wykładowcy, internauci, ale inwazja eventowej kultury w murach uczelni trwa.

W świetle teorii obrzędów mianowania można mówić o nowym statusie zwycięzców konkursu, ich nowej roli. Sa oni bowiem wybranymi z wybranych, osobami, które zostały dopuszczone do przemiany i przeszły na nowy, wyższy poziom. Na stronie Laurów Cezara czytamy:

Specjalnie dla nas mówi: anonimowy laureat jednej z kategorii $z$ roku 2010:

- Nigdy nie uwierzyłbym, że moje życie się tak zmieni! Stałem się jednym $z$ najbardziej znanych osób na naszym Wydziale. Wyjście na scenę po czerwonym dywanie i w blasku fleszy jest niesamowitym prze-

54 http://wiadomosci.onet.pl/krakow/juwenalia-krakowskie-15-20-maja/Orkys (7.05.2015).

55 https://niedlamissumk.wordpress.com/ (7.05.2015). 
życiem! Musisz tego spróbować! Wybaczcie, że poprosiłem Was o anonimowość, ale boję się ujawniać, ze względu na moich fanów, którzy nie odstępują mnie na krok! Już wiem co to znaczy być „tapmadel”56.

Wykładowca, jak widać, stał się pop-bohaterem swojego wydziału. Jaki bowiem nadano mu status i jak się $z$ nim mierzy? Jest to status wykładowcy najbardziej „pop”. Musi być więc bardzo wyluzowany, wyjątkowo dowcipny, zdecydowanie na czasie. Język tej wypowiedzi, szczególnie użycie żartobliwego określenia używanego w stosunku do programy "Top model” (popularnego w każdym tego słowa znaczeniu), pokazuje, jak anonimowy wykładowca świetnie demaskuje swoja nowa „pop-rolę”. Czy przepis swojej roli znaja także zwycięzcy i zwyciężczynie studenckich konkursów piękności i popularności? Co wiąże się ze statusem najładniejszej osoby na uniwersytecie? Tytuł zobowiąuje. Ale do czego? Kobiety i mężczyźni, którzy wygrywają konkursy piękności, przez jakiś czas (zwykle do kolejnych wyborów) reprezentuja swoją społeczność na różnych polach ${ }^{57}$. Jeśli podobnie reprezentantami uczelni wyższych maja być laureaci pop-konkursów, tzn. że trzeba być ładnym (przystojnym) i sympatycznym, żeby stać się twarza szkoły wyższej. Jest to typowe dla rytuałów: pewne środki i sposoby postępowania (wybieranie miss wydziału) prowadza do celów $z$ innego porządku (wydział ma reprezentanta czy reprezentantkę, umacnia się społeczność). To takie udawanie, mówiąc jezzykiem nazw omawianych konkursów, że miss uniwersytetu jest superstudentką (choć do konkursów z przedrostkiem "super-" w przywołanych eventach kobiety dostępu nie maja) i że superstudent i superstudentka to najlepsi studenci na danej uczelni.

Jeśli łączymy rytuały jedynie ze sfera sacrum, o czym była już mowa wyżej, definiujemy je wassko i znacznie ograniczamy możliwości zastosowania tej kategorii do opisu rzeczywistości społecznej ${ }^{58}$. Swoistym kompromisem w tej sytuacji może być stwierdzenie, że w rytuałach zawsze obecny jest jakiś element metafizyczny (idee, przekonania, wiara w coś), nawet jeśli jest to element pozareligijny ${ }^{59}$. W tym sensie rytuały sytuuja

\footnotetext{
56 https://sites.google.com/site/laurycezara/ (7.05.2015).

57 M. Segalen, Obrzędy i rytuały..., s. 49.

58 S. Jaskulska, „Rytuał przejścia”..., s. 83.

59 Z. Mach, Rytuat, s. 357.
} 
się między działaniem a ideologia ${ }^{60}$. Można więc $z$ nich odczytywać światopoglad dominujacy w danej kulturze. Wiele o kierunku zmian uczelni wyższych może więc powiedzieć ich rytualne, także pop-rytualne oblicze. Pop-rytuały sa bowiem, po pierwsze, odbiciem ogólnych, dominujących w kulturze trendów oraz kulturowej deklasyfikacji współczesnego społeczeństwa polskiego. Pisałam wyżej, że pop-rytuały tak jak inne obrzędy mają na celu spajanie, łączenie społeczności. Należy jednak pamiętać o tym, że choć wpisuja się w dominujące trendy kulturowe, to jednak dzieją się w murach uczelni. Nie każdy może wziąc udział w wyborach superstudenta, trzeba być bowiem studentem, i to takim, który przejdzie z sukcesem casting. Warto przyjrzeć się podwójnemu wykluczaniu wpisanemu w rytualność danej społeczności. Należy być osoba, która spełnia warunki danego obrzędu, ale przede wszystkim trzeba być członkiem społeczności. Wyniki badań zatytułowanych „W jakim czasie kultury żyja Polacy? Nowy rytualizm i budowanie alternatywnych subświatów jako dominujace praktyki kulturowe"61 pokazuja, jak współczesna rytualność „festiwalowa” wprowadza w społeczeństwie wyraźne podziały na ludzi, których stać na udział w pewnych wydarzeniach, i tych, którzy musza zadowolić się innymi. Linia podziału nie pokrywa się $z$ rysowana kiedyś oddzielająca kulturę wysoka od niskiej. Nie wszystko, co pop-kulturowe, dostępne jest wszystkim. Szlendak, jeden z kierowników przywołanego projektu, mówi o festiwalizacji kultury, która staje się „maszyną do dzielenia"62 społeczeństwa. W tym sensie kulturowa wszystkożerność społeczności uczeni wyższych być może jest po prostu nowym wymiarem jej uprzywilejowania. Pop-uprzywilejowania.

Po drugie, pop-rytuały są przejawem przemian, którym podlegaja uniwersytety szukające swoich miejsc na rynku edukacyjnym, który w coraz większym stopniu jest właśnie rynkiem $z$ wszelkimi tego konsekwencjami. Uczelnie wyższe postrzegane sa przez pryzmat tego, co moga zaoferować, a ma to być oferta atrakcyjna. Można zwiększać atrakcyjność

60 M. Buchowski, W.J. Burszta, O założeniach interpretacji antropologicznej, PWN, Warszawa 1992, s. 53.

${ }^{61}$ Badania kierowane przez Tomasza Szlendaka i Krzysztofa Olechnickiego, a prowadzone przez Elbląskie Towarzystwo Naukowe im. Jana Myliusa za środki pochodzące z MKiDN.

${ }^{62}$ Maszyna do dzielenia... 
uczelni, podnosząc kwalifikacje kadry nauczycielskiej, dbajac o najlepszy sprzęt badawczy, ciągłość i rzetelność prowadzonych badań, działalność wydawniczą. Jeśli natomiast zewnętrzne wymagania nie idą w kierunku jakości „świadczonych usług”, ale ich przyjaznej studentowi formy, ułatwień w zdobywaniu wiedzy i dyplomów, miłej atmosfery i klimatu pracy przez zabawę, konkursy typu wybory miss uniwersytetu ofertę tę znacznie uatrakcyjniaja. A uczelnie wyższe robią w ten sposób krok w stronę kultury popularnej.

Słowa kluczowe: uniwersytet, rytuały, obrzędowość, kultura popularna, konkursy popularności

\section{THE POP-RITUAL SIDE OF THE UNIVERSITY}

\section{Summary}

The aim of this paper is to take a closer look at university pop-rituals that can be treated as one of the elements of what a contemporary high school is. Rituals or rites of an institution reflect its culture understood as a selection of values, symbols, attitudes, ideas, beliefs and customs. In the text, I analyze the phenomena that are present at universities and that I refer to as pop rituals (various contests, parties organized at universities), and beforehand I explain that the concept of an institution's pop-ritual side stands for in my view. The subject of the considerations that I undertake is thus the presence of phenomena typical for pop culture within the walls of high schools, possible reasons and consequences of his state of affairs, especially the positioning of a university on the so-called educational services market and new dimensions of the privileges of members of academic communities,

Keywords: university, rituals, rites, pop culture, popularity contests 



\section{AnnaWach-Kąkolewicz}

Uniwersytet Ekonomiczny w Poznaniu

Mariusz Kąkolewicz

Uniwersytet im. Adama Mickiewicza w Poznaniu

\section{Portfolio uczenia się jako metoda wspomagająca rozwój kompetencji do nauczania młodej kadry akademickiej}

\section{Wprowadzenie}

Uczenie się jest procesem dochodzenia do wiedzy i ze swej natury jest społecznym procesem opanowywania narzędzi kulturowych. Najnowsze ustalenia psychologii poznawczej i szerzej kognitywistyki wskazuja jednoznacznie, że wiedza rozumiana jako charakterystyka umysłu może być kształtowana i konstruowana jedynie w wyniku aktywności poznawczej uczącego się. Koncepcja konstruktywizmu jako teorii i praktyki edukacyjnej wywodzi się z prac Johna Deweya, Jeana Piageta, Lwa Wygotskiego oraz Jeroma Brunera. Istotą konstruktywistycznego podejścia do rozważania procesów edukacyjnych jest zwrócenie uwagi na podmiotowość i odpowiedzialność jednostki w dochodzeniu do wiedzy i poszerzania własnych kompetencji. Oznacza to przeniesienie środka ciężkości $z$ nauczania (bycia nauczanym) na proces podmiotowego i aktywnego uczenia się. Ernst von Glasersfeld wyraził to słowami: „struktury pojęciowe, które konstytuuja znaczenia lub wiedzę, sa konstruktami, które każdy

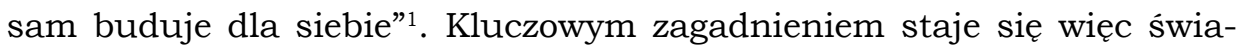
dome konstruowanie i przekonstruowywanie schematów i struktur poznawczych zachodzace na skutek refleksyjnego namysłu i konfrontacji

1 E. von Glasersfeld, Introduction: Aspects of Constructivism, w: Constructivism. Theory, Perspectives and Practice, red. C.T. Fosnot, Techers College Press, Columbia University, New York-London 2005, s. 5. 
tego, „co wiem”, z nowymi bodźcami informacyjnymi ze świata zewnętrznego (naturalnego i medialnego) oraz wiedza innych: współuczących się i nauczycieli (negocjowanie znaczeń). Na znaczenie refleksji w podejmowanych działaniach uczenia się, nabywania i doskonalenia kompetencji jako pierwszy zwrócił uwagę Donald Schön ${ }^{2}$, upowszechniając pojęcie refleksyjnego praktyka. Wielu pedagogów analizujacych i badajacych procesy uczenia się odwołuje się do modelu uczenia się przez doświadczanie zaproponowanego przez Davida $\mathrm{Kolba}^{3}$, zgodnie z którym kluczowa rolę w cyklu uczenia się pełni refleksja. Stanowi ona także istotny czynnik rozwoju kompetencji nauczycieli ${ }^{4}$, w tym nauczycieli akademickich ${ }^{5}$.

Do wspomagania uczenia się zgodnie $z$ koncepcją konstruktywizmu coraz częściej stosowana metodą stymulujaca lub wręcz wymuszajaca uruchamianie refleksji nad indywidualnymi procesami uczenia się jest portfolio. W artykule zamierzamy zaprezentować jego istotę, potencjał i znaczenie w procesie uczenia się, uzupełniając rozważania teoretyczne przykładem wykorzystania portfolio jako metody, a także narzędzia rozwoju kompetencji do nauczania stosowanego podczas Kursu Pedagogicznego dla Młodej Kadry Uniwersytetu Ekonomicznego w Poznaniu.

\section{Istota portfolio uczenia się}

Pojęcie „portfolio” rozumiane jest zwykle jako dokumentacja wytworów i efektów czyichś działań twórczych. Tradycyjnie odnosi się ono do zbioru przykładowych prac artysty. Najczęściej prac projektantów form przemysłowych lub odzieży, zdjęć zawodowych fotografów, grafików rekla-

2 D. Schön, The Reflective Practitioner. How Professionals Think in Action, Temple Smith, London 1983.

3 D.A. Kolb, Experiential Learning: Experience as the Source of Learning and Development, Prentice Hall, Englewood Cliffs, New Jersey 1984.

4 B.D. Gołębniak, Zmiany edukacji nauczycieli. Wiedza - biegłość - refleksyjność, Edytor, Toruń 1998.

5 Por. A. Sajdak, Paradygmaty kształcenia studentów i wspierania rozwoju nauczycieli akademickich. Teoretyczne podstawy dydaktyki akademickiej, Impuls, Kraków 2013; T. Olsson, K. Mårtensson, T. Roxå, Pedagogical Competence - A Development Perspective from Lund University, w: A. Ryegård, K. Apelgren, T. Olsson, A Swedish Perspective on Pedagogical Competence, Uppsala University, Division for Development of Teaching and Learning, Uppsala 2010; A. Wach-Kakkolewicz, Rozwój kompetencji pedagogicznych nauczycieli akademickich - potrzeby i działania, „Neodidagmata” 2013, nr 35. 
mowych, projektów i realizacji architektonicznych, ale również np. zdjęć modelek. Stanowi ono wówczas udokumentowanie posiadanych możliwości i dokonań zaświadczające o zdolnościach i umiejętnościach zawodowych. Portfolio takie prezentowane jest np. przy staraniu się o kolejne zamówienie lub zlecenie.

W ostatnich dekadach, gdy wraz ze wzrostem konkurencyjności na korporacyjnym rynku pracy coraz większe znaczenie zaczęto przywiązywać do zweryfikowanych kompetencji i kreatywności kandydata, dobre portfolio dokumentujace rozwój kwalifikacji i kariery zawodowej staje się znaczacym argumentem przy ubieganiu się o wyższe menedżerskie stanowisko w innej korporacji. Dodać należy, że w kontekście ekonomicznym określenie „portfolio” stanowić może synonim portfela inwestycyjnego, czyli zbioru finansowych i realnych aktywów inwestora.

Pod koniec ubiegłego wieku tworzenie i wykorzystywanie portfolio służącego do dokumentowania działań związanych $z$ procesem uczenia się zaczęto zalecać studentom na uczelniach amerykańskich, a od kilku lat także w Polsce. Portfolio wspomaga proces uczenia się (o czym dalej), ale również może służyć samodzielnej i zewnętrznej (przez nauczyciela akademickiego) ewaluacji podejmowanych działań. Celem portfolio dokumentujacego studiowanie jest nie tylko gromadzenie prac zlecanych do wykonania przez wykładowców i zadań podejmowanych samodzielnie, ale przede wszystkim stymulowanie do podejmowania i angażowania się studenta w analizowanie procesu indywidualnego uczenia się poprzez osobista refleksyjna dyskusję nad materiałami zawartymi w portfolio ${ }^{6}$. Portfolio takie ma więc służyć głównie uświadamianiu sobie, wzbogacaniu i ewaluacji własnych kompetencji i znaczenia samodzielnego dochodzenia do wiedzy. Peter Seldin ${ }^{7}$ najważniejsze korzyści, jakie daje uczącemu się tworzenie portfolio, ujął w następująca listę:

a) umożliwia uchwycenie istoty poznawanych zagadnień, pogłębione uczenie się i ewaluacje procesu;

6 L. Annis (Ferrill), C. Jones, Student Portfolios: Their Objectives, Development, and Use, w: P. Seldin\& Associates, Improving College Teaching, Anker, Bolton, Massachusetts 1995, s. 181-190; J. Zubizarreta, The Learning Portfolios, Anker Publishing Company Inc., San Francisco 2004; E. Filipiak, Rozwijanie zdolności uczenia się. Z Wygotskim i Brunerem $w$ tle, GWP, Sopot 2012.

7 J. Zubizarreta, The Learning Portfolios, s. xi. 
b) wspiera rozwój, demonstrowanie i wartościową ocenę wielu osobistych, profesjonalnych i akademickich możliwości uczącego się;

c) zachęca uczącego się do wchodzenia w nową rolę w dokumentowaniu, obserwacji i rekapitulacji własnego uczenia się;

d) wspiera integrowanie uczenia się różnych zagadnień kursu i programu studiów;

e) zwiększa możliwość osobistego wartościowania efektów uczenia się zamiast polegania wyłącznie na ocenie innych;

f) angażuje uczącego się w materię przedmiotu tak, że łatwiej zachodzi przetwarzanie i internalizacja nowych zagadnień;

g) umożliwia analizę postępów edukacyjnych poprzez przegląd kolejnych kroków na drodze do wiedzy;

h) umożliwia pogłębiona analizę poznawanych faktów i zagadnień będąca następstwem głębszej refleksji.

Znaczenie pogłębiania refleksji nad własnym uczeniem sie jako największą zaletę portfolio podkreśla wielu autorów ${ }^{8}$. Tworzenie portfolio powoduje bowiem, że notatki towarzyszace procesowi uczenia się jako swoiste artefakty dokumentujące proces uczenia się umożliwiaja pełniejsze uświadamianie sobie własnej wiedzy i jej strukturyzowanie.

Portfolio ujawnia także znaczenie refleksji w uczeniu się towarzyszącym różnego rodzaju pozauczelnianym formom aktywności studenta, a zwiąanym $z$ wykonywana praca, $\mathrm{np}$. w trakcie wolontariatu czy praktyk zawodowych. Zarówno studenckie praktyki zawodowe, jak i podejmowana przez studenta praca sa okazja do wykorzystywania wiedzy oraz zdobywania nowej w sytuacjach umiejscowienia ${ }^{9}$, czyli uczenia się poprzez wykonywanie pracy w konkretnych, specyficznych dla jej charakteru warunkach. Osobiste doświadczenia zdobywane w warunkach podobnych np. do przyszłej pracy zawodowej służą akumulowaniu wiedzy ukrytej ${ }^{10}$. Nawet w trakcie dobrze wykonywanej pracy, np. podczas praktyki zawo-

8 Por. J.A. Moon, A Handbook of Reflective and Experiential Learning. Theory and Practice, Routledge Falmer, London-New York 2005; L. Stefani, R. Mason, Ch. Pegler, The Educational Potential of E-portfolios. Supporting Personal Development and Reflective Learning, Routledge, Milton Park, Abington 2007.

9 J. Lave, E. Wenger, Situated Learning. Legitimate Peripheral Participation, Cambridge University Press, New York 1991/2007.

${ }^{10}$ M. Polanyi, The Tacit Dimension, University of Chicago Press, Chicago-London 1966. 
dowej, można się niewiele nauczyć, ale dzięki pogłębieniu refleksji nad własnym działaniem praktycznym, do czego stymulować będzie również wtedy prowadzone portfolio, można uczyć się wykorzystywania i odnoszenia do praktyki wiedzy zdobywanej w trakcie studiów ${ }^{11}$. Tworzenie portfolio dokumentujacego zdobywanie wiedzy poprzez działania poznawcze w realnych sytuacjach uczenia się związanych z praca stymulować będzie zarówno refleksję, jak i będąca jej następstwem konwersję elementów wiedzy ukrytej do wiedzy jawnej. Refleksyjne analizowanie własnych procesów uczenia się i osobistych dróg dochodzenia do wiedzy stymulowane np. poprzez zadawanie sobie określonych pytań i notowanie w portfolio odpowiedzi oraz namysł nad procesem tworzenia i analizowania zasobów portfolio służy także budowaniu metawiedzy, czyli wiedzy o osobistych procesach poznawczych.

Inspirowanie refleksji nad własnymi procesami uczenia się ${ }^{12}$ może przebiegać w różny sposób. Portfolio uczenia się może np. zawierać moduł zawierajacy odpowiedzi na zasugerowane przez nauczyciela pytania, jakie jego zdaniem studiujacy powinien sobie postawić i które opisywać będa jego własne uczenie się $\mathrm{w}$ powiąaniu $z$ : celami, treścia, formami, procesem i ewaluacja uczenia się. Bardziej samodzielna formą będzie zapisywanie w portfolio odpowiedzi na takie pytania, jak: Czego nauczyłem się na konkretnych zajecciach? Czy to jest to, czego zamierzałem się nauczyć? Czego jeszcze powinienem się nauczyć? Co mogę i powinienem zrobić, aby się tego nauczyć?

Portfolio sprowadzone jednak tylko do zapisywania przez uczącego się odpowiedzi na zaproponowany przez nauczyciela zbiór pytań byłoby jego nadmierna formalizacją. Portfolio tworzone głównie w celu przedstawienia go nauczycielowi do analizy i weryfikacji jako formalny wymóg zaliczenia kursu staje się dla studenta również stymulujące, ale może być wówczas tylko kolejnym zadaniem do odrobienia. Podejście takie znaczaco odbiega od roli, jaka może pełnić portfolio, jego głównym celem jest bo-

${ }^{11}$ B.L. Cambridge, Electronic Portfolios as Knowledge Builders, w: Electronic Portfolios: Emerging Practices in Student, Faculty and Institutional Learning, red. B.L. Cambridge, S. Kahn, D.P. Tompkins, K.B. Yancey, American Association for Higher Education, Washington, District Columbia, Stylus Publishing, Sterling, Virginia 2001 (wydanie 2005), s. 3.

12 Por. L. Philip, Encouraging Reflective Practice Amongst Students: a Direct Assessment Approach, „Planet” 2006, no. 17/XII. 
wiem umożliwianie i wspieranie niezależnych od zewnętrznego nacisku, samodzielnych aktywności poznawczych uczacego się i stymulowanie refleksji nad indywidualnym procesem dochodzenia do wiedzy. Tworzacy portfolio musi mieć więc swobodę $\mathrm{w}$ wyborze zarówno stopnia sformalizowania kształtu, jak i struktury portfolio tak, aby mogło ono w jak największym stopniu wyzwalać jego autentyczna kreatywność, samodzielność, refleksyjność i odpowiedzialność za proces własnego uczenia się.

John Zubizarreta ${ }^{13}$ proponuje model portfolio oparty na trzech fundamentalnych składnikach: dokumentacji, refleksji i współpracy. Portfolio staje się wówczas nie tylko zbiorem autorskich opracowań towarzyszących procesowi uczenia się, które dalej stanowią źródło refleksji nad własnym procesem uczenia się dokumentowanej również poprzez osobiste notatki, ale także zarówno opracowania, jak i notatki sa punktem wyjścia do analizy i zewnętrznej weryfikacji poprzez dzielenie się nimi i dyskutowanie zarówno ze współuczącymi się, jak i (nawet częściej) z nauczycielem-tutorem. Konfrontowanie dokumentacji procesu i osobistych refleksji umożliwia weryfikację własnej wiedzy i przemyśleń poprzez konstruktywistyczne negocjowanie rozumienia pojęć we współpracy $z$ innymi uczestnikami społecznego procesu konstruowania wiedzy.

Zarówno tworzenie, jak i dyskutowanie własnych przemyśleń i interpretacji staje się w ostatniej dekadzie znacznie prostsze i na swój sposób wygodniejsze dzięki mobilnym narzędziom, takim jak tablety i smartfony, oraz technologiom łączności bezprzewodowej i zapisywania w "chmurze”. Wykorzystanie technologii informatycznych umożliwia tworzenie portfolio, dostęp do jego zapisów i udostępnianie ich we współpracy w dowolnym miejscu i czasie. Taką formę określamy jako e-portfolio, które stwarza uczącym się wiele nowych możliwości. Notatki nie tylko moga być tworzone w dowolnej formie medialnej, ale również strukturyzowane poprzez hyperlinki. Zagadnienia korzyści wynikających $z$ tworzenia e-portfolio zostały szczegółowo omówione przez Mariusza Kakolewicza ${ }^{14}$.

13 J. Zubizarreta, The Learning Portfolios, s. 20.

${ }^{14}$ M. Kąkolewicz, Uczenie sie jako konstruowanie wiedzy. Świadomość, qualia i technologie informacyjne, Wyd. UAM, Poznań 2011. 


\section{Portfolio uczenia się jako metoda rozwoju kompetencji dydaktycznych - studium przypadku Kursu Pedagogicznego dla Młodej Kadry UEP}

Przygotowanie kadry dydaktycznej do prowadzenia zajęć jest różnorodnie realizowane w polskich uczelniach, co zwiazane jest $z$ faktem, że uczelnie wyższe nie podlegają żadnym formalnym wymogom ministerialnym w tym zakresie ${ }^{15}$. Uniwersytet Ekonomiczny w Poznaniu ma spore doświadczenie w prowadzeniu zajęć dla rozpoczynajacych swoja pracę dydaktyczna młodych nauczycieli akademickich ${ }^{16}$, jednak program, formy i metody pracy stosowane na zajęciach przygotowujacych do nauczania akademickiego ewaluowały przez lata, także pod wpływem rozwoju myśli pedagogicznej. Obecny ${ }^{17}$ Uczelniany Kurs Pedagogiczny dla Młodej Kadry UEP to jednosemestralne 150-godzinne szkolenie doskonalace adresowane do adeptów akademickiej pracy dydaktycznej, głównie doktorantów oraz młodych asystentów i adiunktów. Program zajęć obejmuje zagadnienia współczesnej pedagogiki i psychologii kształcenia, w tym projektowania i prowadzenia zajęć, a także oceny i ewaluacji procesu dydaktycznego. Uczestnicy kursu poznaja techniki emisji głosu oraz reguły przygotowywania i prowadzenia wystąpień publicznych. W trakcie zajęć osoby szkolące się doskonalą umiejętności komunikowania interpersonalnego, budowania zespołu, motywowania studentów i radzenia sobie w trudnych sytuacjach społecznych ${ }^{18}$. W efekcie nabywaja szereg niezbędnych kompetencji do nauczania, w zakres których wchodzą: kompetencje metodyczne zwiąane $z$ dydaktyka ogólna, kompetencje w obszarze

15 Wyjątek stanowi rozporzadzenie MNiSW z 1 września 2011 r. w sprawie kształcenia na studiach doktoranckich, § 4, pkt 2 dotyczące fakultatywnych zajęć rozwijających umiejętności dydaktyczne i zawodowe, przygotowujacych ich do roli nauczyciela akademickiego, w szczególności w zakresie metodyki zajęć dydaktycznych i nowych technologii wykorzystywanych w kształceniu studentów.

${ }^{16}$ Zajęcia pedagogiczne dla nauczycieli akademickich zostały zainicjowane już w połowie lat 60. ubiegłego wieku, a formalnie studium pedagogiczne powołane zostało $\mathrm{w}$ roku akademickim 1969/1970. W latach 70. zajęcia realizowane były w Zakładzie Nowych Technik Nauczania UAM, a następnie, w latach 80., ich organizacja została przejęta przez pracowników Akademii Ekonomicznej, w której regularnie co rok lub co dwa lata uruchamiano kolejną edycję aż do roku 2005 włącznie.

${ }^{17}$ Od 2011 r. prowadzony jest Ogólnouczelniany Kurs Pedagogiczny dla Młodej Kadry UEP w zmienionej pod względem programowym formule. Każdego roku uczestniczy w nim 25 doktorantów/asystentów/adiunktów. W 2015 r. odbyła się jego V edycja.

18 A. Wach-Kąkolewicz, Rozwój kompetencji... 
dydaktyki przedmiotowej, kompetencje systemowe związane $z$ warunkami realizacji procesu kształcenia w danej uczelni, kompetencje społeczne, a także kompetencje osobowe ${ }^{19}$. Zajęcia na kursie pedagogicznym realizowane sa przez cały semestr $\mathrm{w}$ sesjach kilkugodzinnych, prowadzone głównie w formie warsztatowej, aktywizującej, tak by wyzwolić zaangażowanie, refleksję i krytyczne myślenie. Na zaliczenie (poza obecnościa na zajęciach) słuchacze przygotowuja $\mathrm{w}$ grupach obudowane $\mathrm{w}$ media edukacyjne (często tematycznie interdyscyplinarne) scenariusze zajęć. Ta forma zaliczenia integruje uczestników, stymuluje do dyskusji na temat wszystkich elementów procesu dydaktycznego, co sprawia, że słuchacze finalnie mogą się pochwalić bardzo ciekawymi pracami.

Inna, bardziej zindywidualizowana forma zaliczenia, ale jednocześnie będącą narzędziem rozwoju kompetencji, którą wprowadziliśmy na kursie w 2014 roku, jest portfolio uczenia się. O jego cechach, elementach oraz zaletach pisaliśmy powyżej. W tej części postaramy się pokazać, w jaki sposób portfolio uczenia się jest wykorzystywane na kursie pedagogicznym, jakie są założenia jego tworzenia oraz czemu służy. Zdecydowaliśmy się na taką formę zaliczenia, ponieważ wychodząc $z$ konstruktywistycznych założeń procesu uczenia się, zakładamy, iż refleksja w działaniu i nad działaniem jest kluczowym elementem rozwoju ${ }^{20}$. Ponadto, kurs trwa jeden semestr, zatem jest czas na pogłębioną analizę i przemyślenia, również na wdrożenie niektórych proponowanych w ramach kursu strategii czy rozwiazań edukacyjnych do warsztatu pracy nauczycielskiej. W portfolio moga i powinny znaleźć się także refleksje $z$ tym związane. Przypomnijmy, że portfolio służy nie tylko dokumentowaniu własnego rozwoju poprzez gromadzenie materiałów, zbieranie w jednym miejscu różnego typu informacji związanych z przedmiotem studiowania, ale służy też ich porząkowaniu, przetwarzaniu i budowaniu struktur wiedzy. Portfolio, którego głównym elementem (w tym przypadku) jest tekst pisany, poprzez sam akt pisania (tworzenia) daje czas do namysłu, analizy i refleksji. Uruchamia także krytyczne myślenie oraz planowanie

19 I. Stahr, Academic Staff Development: Entwicklung von Lehrkompetenz, w: Wandel der Lehr..., za: A. Sajdak, Paradygmaty kształcenia..., s. 205-206.

${ }^{20}$ D. Schön, The Reflective Practitioner...; B.D. Gołębniak, Zmiany edukacji nauczycieli... 
kolejnych działań. Przygotowując słuchaczy do tworzenia portfolio, proponujemy poszukiwać odpowiedzi na następujące pytania:

a) Czego się nauczyłem/am?

b) Co było dla mnie nowe, interesujace, przydatne, pomocne?

c) W jaki sposób się tego nauczyłem/am?

d) Co mi w tym pomogło, a co przeszkadzało?

e) Jaka jest/była moja rola jako uczącego się?

f) Jakie metody, strategie uczenia się były dla mnie korzystne, efektywne?

g) Jaka jest wartość tego, czego się uczyłem/am?

h) Jakim jestem nauczycielem?

i) Jakie mam zasoby, w jakich obszarach nie czuję się pewnie?

j) Jak zmieniło to moje myślenie o uczeniu się/nauczaniu, roli nauczyciela akademickiego pod wpływem zajęć na kursie pedagogicznym?

k) Co chciałbym/chciałabym, mógłbym/mogłabym wykorzystać w mojej pracy dydaktycznej?

1) Jakie sa moje plany dotyczace przyszłego rozwoju jako nauczyciela akademickiego?

m) W jakim zakresie/obszarze chciałbym/chciałabym pogłębiać swoją wiedzę i umiejętności w przyszłości?

n) Nad czym chciałbym/chciałabym popracować i w jaki sposób?

Format przygotowywanych portfolio jest dowolny, słuchacze sami podejmuja decyzję, w jakiej formie chcieliby dokumentować swój rozwój. Część z nich wybiera popularne dziś blogi, część wykorzystuje edytory tekstu, zapisujac swoje przemyślenia w wersji elektronicznej, w formie esejów, rzadziej w postaci tabelarycznej. Zdarzają się także tworzone odręcznie - tradycyjne zaszyty $z$ notatkami $z$ zajęć dodatkowo obudowane $\mathrm{w}$ refleksje, czasem zdjęcia z zajęć czy innych spotkań grup roboczych odbywajacych się w godzinach poza kursem pedagogicznym.

W bardzo obszernym i bogatym materiale (prace 25 uczestników V edycji Kursu Pedagogicznego dla Młodej Kadry UEP) zamieszczonym $\mathrm{w}$ portfolio można zauważyć wiele interesujących refleksyjnych wypowiedzi dotyczących metod kształcenia i potencjału w nich drzemiącego, np.:

Zajęcia dotyczace case study otworzyły mi oczy na potencjał wykorzystania tej metody (Uczestnik 1) 
oraz

Zdałem sobie sprawę, że zbyt mało czasu [podczas zajęć] poświęcam na dyskusję [...] Powinienem pozwolić studentom pracować samodzielnie [...] powinni oni sami omawiać wyniki [dotyczy zajęć laboratoryjnych], a moje zadanie powinno polegać na ewentualnym dopowiedzeniu ważniejszych kwestii... (Uczestnik 2).

W ostatniej wypowiedzi autor akcentuje również swoją rolę jako dydaktyka. W portfoliach nie zabrakło wypowiedzi wskazujacych, że zajęcia na kursie uświadomiły jego uczestnikom potrzebę zmiany podejścia w kierunku organizatora procesu uczenia, moderatora, faciltatora, osoby wspierającej i koordynujacej proces dydaktyczny. O tym świadczą inne wypowiedzi:

Zajęcia dały mi sporo do myślenia na temat mojej roli jako ćwiczeniowa [...] $\mathrm{Na}$ zajęciach zrozumiałam, że warto angażować studentów i dawać im czas na refleksję, a nie podawać gotowe treści (Uczestnik 3)

oraz:

Uświadomiłam sobie, że prowadząc zajęcia w sposób podający ograniczam możliwości rozwoju i kreatywnego myślenia moich studentów (Uczestnik 4).

Inna wypowiedź wskazująca na podjęcie konkretnych działań pod wpływem zajęć na kursie pedagogicznym:

W tym semestrze (pod wpływem zajęć) postanowiłam zastosować się do rad prowadzącej zajęcia i wdrożyłam metody aktywizujące studentów. Na chwilę obecną lepiej mi się je prowadzi i wydaje mi się, że studentom też ta forma odpowiada (Uczestnik 5).

Wiele refleksji poświęcono projektowaniu zajęć dydaktycznych zgodnie $z$ założeniami konstruktywizmu edukacyjnego. Filozofia kształcenia implikujaca konkretne praktyczne wskazówki dotyczące planowania i realizacji zajęć często była przedmiotem analiz słuchaczy kursu. Młodzi nauczyciele zwracali uwagę na swoją dotychczasowa niekompetencję w tym zakresie jak np. w wypowiedzi:

Moją uwagę szczególnie zwróciło to, jak mało wiedzy na temat projektowania zajęć dydaktycznych do tej pory zdobyłem; dotychczas 
zajęcia prowadziłem bardziej intuicyjnie, teraz postaram się je dokładniej planować, a także wykorzystywać poznane metody (Uczestnik 6).

Słuchacze podkreślali, że istotne było uświadomienie sobie swoich braków i niekompetencji w obszarze dydaktyki akademickiej. Dość dobrze obrazuje to kolejna wypowiedź:

Do tej pory nie postrzegałem jakości i sposobu prowadzenia zajęć jako ważnego elementu [...] Kurs uświadomił mi wage procesu [kształcenia studentów] oraz rozbudził pasję do nauczania studentów (Uczestnik 2)

oraz jeszcze inny przykład takiego stanowiska:

Kurs uświadomił mi, że od samego początku [pracy dydaktycznej] miałem „złe” podejście do prowadzenia zajęć; Kurs zainspirował mnie, spowodował, że zmieniłem swoje wyobrażenie o dobrze prowadzonych zajęciach. Dobrze przeprowadzone zajęcia, to nie tylko zrealizowany materiał i względne zrozumienie przez studentów przekazywanych treści [...] To ukierunkowany proces, na początku którego znajduje się problem i brak jego rozwiazania... to proces, w trakcie którego studenci próbuja na podstawie przygotowanych materiałów dydaktycznych dojść do rozwiąania. Nawet jeśli się im nie powiedzie, to na końcu tego procesu wszystko nabiera sensu i rozwiąanie problemu wraz ze stojąca za nim wiedzą wrzyna się w świadomość i pamięć” (Uczestnik 6).

W wielu wypowiedziach pojawiaja się tzw. momenty zwrotne, krytyczne dla kształtowania i rozwoju kompetencji do nauczania, takie jak:

Zajęcia dotyczące wykorzystania cyklu uczenia się wg Kolba bardzo ważne zajęcia - punkt „kulminacyjny”. Od tego momentu kursu moje postępowanie i myślenie [...] o nauczaniu studentów zmieniło się o 180 stopni. Teraz jestem pewny, że idziemy w dobrym kierunku angażując studentów w pracę, a nie podając wszystko na tacy (Uczestnik 7).

Refleksja pojawiała się w związku z zagadnieniami projektowania zajęć, ale również w odpowiedzi na inne zagadnienia, np. zwiazane $z$ wychowywaniem czy oddziaływaniem na swoich studentów, czego przykładem jest wypowiedź:

[Zajęcia Motywowanie do studiowania] osobiście jedne $z$ ważniejszych dla mnie... Uświadomitem sobie, że należy się starać, ale nie przejmować, jeżeli nie wszyscy studenci chca skorzystać, 


\section{z tego, co oferujemy. Ponadto do tej pory nie doceniatem ustnych pochwat (Uczestnik 8).}

Uczestnicy szkolenia w swoich wypowiedziach zwracali uwage na kwestie niewątpliwie najważniejsze dla nich i takie, które pozwoliły na rozwój dotychczasowych umiejętności prowadzenia zajęć. Wiele $z$ nich miało bardzo praktyczny charakter:

Uświadomiłem sobie, że na zajęciach muszę ukazywać więcej możliwości aplikacyjnych, dlatego, że studenci lubia wiedzieć, dlaczego mają się uczyć (Uczestnik 8)

oraz:

Po tych zajęciach [dotyczących wystąpień publicznych] zacząłem zwracać większa uwagę na to, w jaki sposób prowadzę zajęcia, jaka przyjmuję pozycję, jak się wypowiadam (Uczestnik 6).

Wśród wielu wypowiedzi były także takie, które wyraźnie odnosiły się do całego Kursu i roli refleksji w procesie nabywania i doskonalenia kompetencji do nauczania, np.:

Udział w kursie pedagogicznym przyczynił się do znaczącej poprawy moich kompetencji dydaktycznych, a przede wszystkim skłonił do refleksji nad zajęciami, które prowadziłem w przeszłości (Uczestnik 8).

Przedstawione powyżej wypowiedzi to tylko egzemplifikacje myślenia refleksyjnego poczatkujących nauczycieli akademickich, nie jest to pełna analiza jakościowa wszystkich wypowiedzi zawarta w portfolio. Pogłębione studia nad treścia portfolio nie wchodza w zakres niniejszego artykułu. Uzyskane wyniki i wnioski z badań zostaną opublikowane w późniejszym okresie.

\section{Refleksja nad refleksją}

Z założenia portfolio jest narzędziem, które aby spełniało swoje funkcje, powinno być prowadzone regularnie, na bieżąco po każdym dniu zajęć, ewentualnie bloku zajęć. Aby zmotywować słuchaczy do bieżącej pracy nad portfolio, ale także by dać możliwość zaprezentowania swoich 
przemyśleń w dialogu i interakcji (które są trzecim istotnym elementem wspomnianego modelu portfolio), wprowadziliśmy w ubiegłej edycji Kursu jako swoiste novum spotkania w trakcie trwania kursu w grupach kilkuosobowych nazywanych „Refleksja nad refleksja”. W trakcie takich sesji uczestnicy Kursu, siedząc w kręgu, dzielili się swoimi dotychczasowymi spostrzeżeniami i zapisanymi refleksjami, poszukując odpowiedzi na pytania: Co i w jaki sposób miało znaczący wpływ na rozwój moich kompetencji do nauczania w trakcie trwania kursu? Co się zmieniło w moim myśleniu o procesie akademickiego uczenia się/nauczania oraz jakie to ma/będzie miało przełożenie na moja własna praktykę dydaktyczną? Próbowaliśmy stworzyć atmosferę zaufania, otwartości i poczucia bezpieczeństwa w relacjach (o co zabiegamy zreszta od samego poczatku każdej z edycji kursu pedagogicznego), tak by uczestnicy szkolenia chcieli dzielić się swoimi przemyśleniami, a także doświadczeniami, które sa i sukcesami, i porażkami. Otwartość, z jaka się spotkaliśmy, przeszła nasze najśmielsze oczekiwania. Jakościowa analiza potężnego materiału badawczego ${ }^{21}$ dopiero potwierdzi wrażenia osób prowadzących sesję. Poza uruchomieniem refleksji i krytycznego wejrzenia w siebie uczestnicy spotkania dawali sobie nawzajem wsparcie, a także szukali wspólnie rozwiązań różnych problemów dydaktycznych, z jakimi się borykają. Dyskusje dotyczyły również pozytywnych doświadczeń i sukcesów młodych nauczycieli akademickich. Wypowiedzi z portfolio wskazuja, że w trakcie takich spotkań kreowana jest przestrzeń do dyskusji, uruchamiania i wyzwalania refleksji oraz krytycznego myślenia, a młodzi nauczyciele wchodzący dopiero co w meandry sztuki dydaktyki akademickiej uzyskują bezcenne wsparcie kolegów i koleżanek po fachu. Poniżej kilka egzemplifikacji:

W trakcie spotkania każdy członek grupy mógł podzielić się fragmentem swojego portfolio i przedyskutować własne refleksje, takie spotkania powinny odbywać się częściej (Uczestnik 2).

Największa wartością w trakcie rozmów o portfolio stanowiła bez wattpienia możliwość wymiany naszych wspólnych doświadczeń [...], ta forma pracy jest bardzo przydatna, dzielimy się ze sobą swoimi doświadczeniami (Uczestnik 9).

${ }^{21}$ Materiał badawczy stanowia wypowiedzi uczestników sesji „Refleksja nad refleksja”, które zostana poddane analizie badawczej i opublikowane w oddzielnym opracowaniu. 
Opracowanie portfolio jest bardzo dobrym pomysłem, bo wymusza pewna systematyczność przemyśleń, rozmowy w grupach na temat mogłyby być nawet częściej (Uczestnik 10).

\section{Od portfolio uczenia się do portfolio nauczania - podsumowanie}

Wykorzystywanie portfolio uczenia się jako metody pracy stymulującej i wyzwalającej refleksję nad własnym rozwojem ma wiele zalet, o których pisaliśmy powyżej. Aczkolwiek warto wspomnieć jeszcze o innym powodzie zastosowania tej metody i jednocześnie swoistego narzędzia na zajęciach pedagogicznych dla młodych nauczycieli akademickich, jakim jest wdrożenie młodych dydaktyków do tworzenia w przyszłości (ciagle jeszcze mało stosowanego w polskich uczelniach) portfolio nauczyciela akademickiego ${ }^{22}$. Podobnie jak portfolio uczenia się służy ono dokumentowaniu rozwoju oparzonego pogłębioną refleksja nad warsztatem dydaktycznym i może być pomocne przy ubieganiu się o pracę, co zreszta jest wymogiem wielu szkół wyższych na świecie (w tym szczególnie uczelni skandynawskich ${ }^{23}$ ). Często stanowi również podstawę do oceny kompetencji do nauczania przy ocenie okresowej pracowników naukowo-dydaktycznych. Może być też punktem wyjścia do rozmowy w procesie hospitacji wspierajacych ${ }^{24} z$ metodykiem kształcenia doradzającym kierunki i obszary zmian, a także istotnym dokumentem przedkładanym w procesie ubiegania się o prestiżowy tytuł bardzo dobrego dydaktyka nazywanego excellence in teaching.

Młodzi nauczyciele akademiccy zachęceni do tworzenia portfolio uczenia się dokumentującego rozwój ich kompetencji dydaktycznych podczas kursu pedagogicznego $z$ jednej strony prezentowali i analizowali swój rozwój jako uczestników szkolenia, $z$ drugiej strony sięgając do swoich jeszcze niezbyt bogatych doświadczeń nauczycielskich, dokonywali swoistej ich ewaluacji. Zestawiali w nich swoje dotychczasowe wyobrażenia na te-

22 P. Seldin, J.E. Miller, The Academic Portfolio. A Practical Guide to Documenting Teaching, Research, and Service, Jossey-Bass, San Francisco 2009.

23 Å. Ryegård, K. Apelgren, T. Olsson, A Swedish Perspective...

${ }^{24}$ A. Wach-Kąkolewicz, Hospitacje zajęć ukierunkowane na wspieranie rozwoju kompetencji dydaktycznych nauczycieli akademickich, „Edukacja Ekonomistów i Menedżerów" 2015, nr 2 (36). 
mat roli nauczyciela (wynikające często $z$ doświadczeń bycia studentem i kilkuletniej obserwacji prowadzących zajęcia) $z$ wiedzą i umiejętnościami zdobywanymi w trakcie szkolenia oraz ich własna praktyka dydaktyczna. Prowadzenie portfolio służyło więc $\mathrm{w}$ tym przypadku nie tylko stymulowaniu namysłu nad zdobywana w trakcie kursu wiedza pedagogiczna, ale także (jak pokazują analizowane powyżej przykłady zapisów z portfolio słuchaczy) umożliwiało refleksyjne wdrażanie jej do własnej pracy ze studentami oraz konfrontowanie poznawanych metod $z$ wcześniejszymi, stosowanymi najczęściej intuicyjnie. Można zatem powiedzieć, że portfolio uczenia się $\mathrm{w}$ wielu przypadkach stawało się $\mathrm{w}$ jakimś stopniu portfolio nauczania, które może być dalej prowadzone, stanowiąc jednocześnie narzędzie i świadectwo rozwoju kompetencji do nauczania.

Słowa kluczowe: portfolio uczenia sie, portfolio nauczyciela akademickiego, kompetencje dydaktyczne/ pedagogiczne, nauczyciel akademicki, szkoła wyższa

\title{
PORTFOLIO AS A SUPPORTING STRATEGY FOR YOUNG ACADEMICS IN TEACHING COMPETENCE DEVELOPMENT
}

\begin{abstract}
Summary
The modern constructivist approach to learning pays attention to the individual's subjectivity and responsibility in knowledge building and skills development. The key element of the process is the reflection that might be understood as the engine of the development and competence improvement. The method/tool which stimulates the reflection is the learning portfolio that has become a central concept of this paper. Next to the theoretical analysis regarding the portfolio features, its potential and its importance, we present the practical example of using the portfolio as a competence development tool that was created by young faculty during Pedagogical Development Programme at the Poznan University of Economics and Business.
\end{abstract}

Keywords: learning portfolio, academic portfolio, teaching skills (competence), university teacher (academic), higher education 



\section{DONIESIENIA Z BADAŃ}





\section{Anna Karpińska}

Uniwersytet w Białymstoku

\section{Niepowodzenia szkolne w retrospekcji studentów pedagogiki}

\section{Niepowodzenia szkolne w dyskursie definicyjnym}

Pojęciu „niepowodzenia szkolne” przypisuje się wielorakie znaczenie. Na tle bogactwa definicyjnego rodzą się niekiedy kontrowersje, ale i inspirujace dywagacje sprzyjajace epistemologicznemu dialogowi ${ }^{1}$.

W literaturze przedmiotu można odnaleźć wiele propozycji wyjaśnienia pojęcia niepowodzeń szkolnych, jednak jak podkreśla Elżbieta Domagała-Zyśk, definicjom tym brak pewnej jednoznaczności².

Najbardziej typowa, a zarazem reprezentatywna dla klasycznej interpretacji konstytutywnego pojęcia zdaje się być definicja Czesława Kupisiewicza, który określając niepowodzenia szkolne lub niepowodzenia dzieci i młodzieży w nauce szkolnej jako „sytuacje, w których występują wyraźne rozbieżności między wymaganiami wychowawczymi i dydaktycznymi szkoły a zachowaniem uczniów oraz uzyskiwanymi przez nich wynikami nauczania"3 ${ }^{3}$,wyznaczył dydaktyczna perspektywę oglądu tego problemu.

W podobny sposób pojęcie to definiuje Halina Spionek ${ }^{4}$. Wincenty Okoń dodaje, że niepowodzenia szkolne obok pojawiania się braków

1 Por. m.in. A. Karpińska, Dialog w obszarze problematyki niepowodzeń dydaktycznych, w: Oblicza dialogu, red. A. Cudowska, Trans Humana, Białystok 2008, s. 97-114.

2 E. Domagała-Zyśk, Terminologia dotyczaca zagadnienia trudności szkolnych $w$ publikacjach anglojęzycznych i jej polskie odpowiedniki, „Roczniki Nauk Społecznych” 2005, t. XXXIII, z. 2, s. 103.

3 C. Kupisiewicz, Podstawy dydaktyki ogólnej, BGW, Warszawa 2005, s. 226.

4 H. Spionek, Zaburzenia rozwoju uczniów a niepowodzenia szkolne, PWN, Warszawa 1985 , s. 76 . 
w wymaganych przez szkołę wiadomościach i umiejętnościach uczniów ${ }^{5}$ oznaczaja także negatywny stosunek młodzieży wobec tych wymagań. Podobnie pojęcie to wyjaśnia Kazimierz Denek, który niepowodzeniami szkolnymi nazywa proces pojawiania się i utrwalania rozbieżności między celami edukacji a osiagnięciami uczniów oraz kształtowania się negatywnego stosunku młodzieży wobec wymagań szkoły ${ }^{6}$. Maria Tyszkowa uważa, że trudności w nauce powstaja jako rezultat rozbieżności między wymaganiami, jakie stawia szkoła, a:

a) możliwościami poznawczymi ucznia i aktualnie osiagniętym przez niego poziomem rozwoju intelektualnego;

b) poziomem psychicznym potrzeb i motywów uczenia się oraz możliwości zaspokajania ich przez naukę szkolna;

c) społeczno-kulturalnymi warunkami życia i rozwoju dziecka współwyznaczającymi zarówno jego możliwości, jak i motywacyjno-osobowościowe warunki uczenia się ${ }^{7}$.

Szwajcarski badacz Martin Tramer, definiując niepowodzenia szkolne, podkreśla przede wszystkim brak harmonii pomiędzy wymaganiami szkoły a postawa ucznia ${ }^{8}$. Jeszcze inaczej pojęcie niepowodzeń szkolnych wyjaśniał Jan Konopnicki, który pojęcie to rozpatrywał łącznie z pojęciem sukcesu, ponieważ jego zdaniem „w nauczaniu tam, gdzie kończy się po-

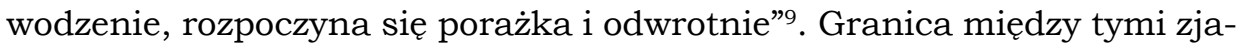
wiskami jest przy tym bardzo subtelna, ponieważ poczucie sukcesu czy porażki jest dość indywidualna sprawa każdego człowieka. Nazywam to względnością niepowodzeń ${ }^{10}$. Zdaniem Konopnickiego jest to stan, w którym znalazło się dziecko na skutek niespełnienia wymagań szkoły ${ }^{11}$.

5 W. Okoń, Nowy słownik pedagogiczny, Żak, Warszawa 2004, s. 274.

6 K. Denek, Powodzenia i niepowodzenia szkolne w kontekście badań, w: Niepowodzenia szkolne, red. J. Łysek, Impuls, Kraków 1998, s. 25.

7 Cyt. za: D. Słodownik, Niepowodzenia szkolne $i$ ich uwarunkowania, http://www. publikacje.edu.pl/publikacje.php?nr=1215 (18.04.2010).

8 C. Kupisiewicz, Niepowodzenia dydaktyczne. Przyczyny oraz niektóre środki zaradcze, PWN, Warszawa 1972, s. 52.

9 J. Konopnicki, Powodzenia i niepowodzenia szkolne, Państwowe Zakłady Wydawnictw Szkolnych, Warszawa 1966, s. 15.

10 A. Karpińska, Niepowodzenia szkolnejako kategoria edukacyjnego dialogu, w: Edukacja w dialogu i reformie, red. A. Karpińska, Trans Humana, Białystok 2002, s. 146.

11 J. Konopnicki, Powodzenia i niepowodzenia... 
Norbert Sillama zwraca natomiast uwage na subiektywizm pojęcia niepowodzeń jako

braku sukcesów w realizacji wyznaczonego sobie celu. Subiektywizm tego zjawiska polega na tym, że część uczniów [...] liczy się z tym, że niepowodzenie w uczeniu się jest nieuniknione, że towarzyszy (w świadomości) zawsze uczacym się, że jest to „stała niewiadoma” występująca przy podejmowaniu i realizacji zadań nowych, trudnych, licznych i realizowanych zwłaszcza w trudnych warunkach ${ }^{12}$.

Zbigniew Kwieciński traktuje niepowodzenia szkolne jako wykluczanie. Symbolizuje ono krzywdy i odtracenia. Określa system czynników selekcyjnych dających większe lub mniejsze możliwości (szanse) uzyskania osiagnięć edukacyjnych. Do grupy wykluczonych zalicza się uczniów, którzy skierowali się na niewłaściwy i niewystarczający w dzisiejszych czasach tor kształcenia, oraz tych ich rówieśników, którzy maja ograniczone szanse włączenia się do ogólnej kultury społecznej poprzez nieopanowanie podstawowych kompetencji szkolnych polegajacych na rozumieniu prostych tekstów w języku ojczystym ${ }^{13}$.

Przytoczone propozycje definiowania niepowodzeń szkolnych sa wyrazem typowego ujęcia zjawiska i tworza kanon wiedzy pedagogicznej w tym zakresie.

Dialog wokół definicji niepowodzeń szkolnych sprowadza się nie tylko do węższego bądź szerszego ich pojmowania ze względu na zakres treściowy. Dotyczy on również prób reinterpretacji pojęcia, które nie może określać wyłącznie niepowodzeń ucznia, gdyż coraz częściej sa to niepowodzenia szkoły jako systemu - niepowodzenia edukacyjne. Za takim rozumieniem niepowodzeń opowiadam się w swoich eksploracjach, traktujac je jako porażkę wielości podmiotów i środowisk w realizacji wielu funkcji przypisanych edukacji14.

12 Cyt. za: K.M. Czarnecki, Źródła trudności i niepowodzeń uczniów klas poczatkowych w uczeniu się pojęć szkolnych (Wyniki badań), w: Niepowodzenia szkolne, s. 126.

13 Z. Kwieciński, Wykluczanie. Badania dynamiczne i porównawcze nad selekcjami społecznymi na pierwszym progu szkolnictwa, Wyd. UMK, Toruń 2002.

14 A. Karpińska, Niepowodzenia edukacyjne - renesans myśli naukowej, Trans Humana, Białystok 2013, s. 100. 


\section{Rodzaje i charakter niepowodzeń szkolnych}

Niepowodzenia szkolne moga występować w formie niepowodzeń dydaktycznych badź wychowawczych, ukrytych bąź jawnych, przejściowych bądź trwałych, odwracalnych bądź nieodwracalnych. Najbardziej ewidentne niepowodzenia to: drugoroczność, wieloroczność, odpad, odsiew szkolny.

Niepowodzenia szkolne moga mieć charakter globalny, gdy obejmuja wszystkie przedmioty, lub częściowy, gdy obejmuja przedmioty niektóre, jeden $z$ przedmiotów lub tylko pewien zakres przedmiotu (np. w przypadku języka polskiego trudności dotyczą tylko czytania lub tylko pisania). Jeszcze innym rodzajem niepowodzeń szkolnych sa niepowodzenia związane $z$ zaległościami $\mathrm{w}$ materiale wynikające $z$ niesystematycznej pracy oraz brak umiejętności uczenia się. Jeśli uczeń nie uczy się systematycznie, zbyt wiele czasu poświęca oglądaniu telewizji czy realizuje zbyt intensywnie swoje zainteresowania pozaszkolne, to trudności w nauce wystapią wcześniej czy później. Jeżeli nie w klasach młodszych, to z pewnościa w starszych, gdy szczególnego znaczenia nabiera własny, samodzielny wkład pracy, gdy konieczne jest ćwiczenie i utrwalanie omówionych na lekcji zagadnień. $Z$ nauką w klasie wyższej wiąże się również większa niż dotychczas ilość materiału do opanowania.

Niepowodzenia szkolne moga mieć charakter losowy lub okolicznościowy. Denek przez „niepowodzenie (opóźnienie) okolicznościowe rozumie sytuację, gdy uczeń posiada zdolności potrzebne do nauki szkolnej, a nie wiedzie mu się dlatego, że staje się on ofiara niesprzyjającego zbiegu okoliczności" ${ }^{15}$. Natomiast niepowodzenia (opóźnienia) losowe wywołane sa takimi psychologicznymi brakami ucznia, jak obniżony iloraz inteligencji ${ }^{16}$. Niepowodzenia szkolne moga być obiektywne, kiedy braki w wiadomościach i umiejętnościach ucznia zostana potwierdzone przez osoby bezstronne. Gdy jednak oceny nie zadowalaja samego ucznia lub jego rodziców, niepowodzenia mają charakter subiektywny ${ }^{17}$.

15 Cyt. za: E. Domagała-Zyśk, Autonomia czy odłaczenie. Rola osoby znaczacej w życiu młodzieży z trudnościami w nauce, Wyd. KUL, Lublin 2004, s. 16.

16 Ibidem.

17 E. Wojda, Rodzaje i przyczyny niepowodzeń szkolnych, „Edukacja i Dialog” 2001, nr 9-10, s. 7 . 
W bogatej literaturze przedmiotu zagadnienie niepowodzeń rozpatruje się wieloaspektowo, zarówno od strony przyczyn, przejawów, konsekwencji, jak i możliwości ich przezwyciężania.

\title{
Konsekwencje niepowodzeń szkolnych
}

Konsekwencje niepowodzeń szkolnych mają zasięg nie tylko doraźny, ale ich skutki można odczuwać przez całe życie.

Eugenia Potulicka w swoich rozważaniach o neoliberalnych uwikłaniach edukacji akcentuje wpływ korporacjonizmu na formowanie jakości ludzkich $\mathrm{w}$ aspekcie jednostkowym, podkreślając tym samym hipokryzję neoliberalizmu, który w swej retoryce wspiera prawa, wolność i godność człowieka, natomiast faktycznie odbiera ludziom ich podmiotowość, sprawczość i autonomię. Formuje też niepokojąco wielką kategorię ludzi, których Zygmunt Bauman w Życiu na przemiał określa mianem „ludzi-odpadów", ludzi przeznaczonych na śmietnik, wykluczonych ze społeczeństwa. Ludziom tym brakuje kontroli nad czynnikami wyznaczajacymi ich pozycję w społeczeństwie oraz warunki ich bytu. U „ludzi zbędnych” - pisze Potulicka -

\begin{abstract}
wytwarzaja się postawy bezradności wraz z towarzyszącym im poczuciem braku własnej godności i sensu życia. Ludzie ci sięgaja dna; sa przytłoczeni bezmiarem odpowiedzialności za własne życie, któremu nie moga $\operatorname{sprostać}^{18}$.
\end{abstract}

W swoich naukowych eksploracjach istotnym obszarem badan czynię skutki niepowodzeń szkolnych analizowane jako następstwa psychologiczne, pedagogiczne, rzadziej ekonomiczne. Diagnozy dotyczą doraźnych, ale częściej odległych konsekwencji opóźnień szkolnych, które stanowia nowe, prospektywne pole badawcze.

W wielu dotychczasowych publikacjach podejmowałam próbę znalezienia odpowiedzi na pytanie, jak z perspektywy czasu dorośli dziś ludzie oceniaja swoje doświadczenia związane $z$ niepowodzeniami szkolnymi; na

18 E. Potulicka, J. Rutkowiak, Neoliberalne uwikłania edukacji, Impuls, Kraków 2010, s. 318 . 
ile owe niepowodzenia zdeterminowały ich los, wpłynęły na aspiracje edukacyjne i życiowe ${ }^{19}$.

\section{Wyimek $\mathbf{z}$ badań}

W tym też nurcie rozważań sytuuje się prezentowana narracja. $\mathrm{W}$ artykule przedstawiam wyniki projektu badawczego realizowanego pod moim kierunkiem wśród studentów I roku kierunku pedagogika ${ }^{20}$. Miał on na celu wniknięcie w losy edukacyjne obecnych studentów z próbą rozpoznania ich ewentualnych niepowodzeń szkolnych oraz określenia wpływu tychże na losy życiowe respondentów, a zwłaszcza decyzję o wyborze kierunku studiów.

Badania miały charakter diagnostyczny. Podejście to zakłada swoistą bezzałożeniowość $\mathrm{w}$ poznawaniu natury danego zjawiska. Oznacza przyjęcie przez badacza postawy „naiwnej poznawczo”, czyli zawieszenia na czas badania swoich przekonań i sądów po to, aby nie ograniczały one horyzontu widzenia badanego zjawiska ${ }^{21}$. Stąd też nie formułowaliśmy hipotez, natomiast ustaliliśmy w sposób precyzyjny problemy badawcze, które wyznaczyły strukturę prezentowanej narracji, zgodnie z która przedstawione zostanie:

- doświadczanie niepowodzeń szkolnych przez obecnych studentów,

- przejawy i obszary ich ewentualnych niepowodzeń szkolnych,

- przyczyny trudności w nauce,

- formy zapobiegania niepowodzeniom szkolnym,

- skutki niepowodzeń szkolnych,

- osiagnięcia i trudności w studiowaniu

19 Por. m.in. A. Karpińska, Człowieczy los naznaczony niepowodzeniami szkolnymi, w: Pedagogika pracy $i$ andragogika $z$ myśla o dorastaniu, dorosłości i starości człowieka $w$ XXI wieku, t. I, Z. Wiatrowski, K. Ciżkowicz, Lega Oficyna Wydawnicza Włocławskiego Towarzystwa, Włocławek 2007, s. 205-218; eadem, Kierunki badań $w$ obszarze niepowodzeń szkolnych, w: Horyzonty rozwoju edukacji w dialogu i perspektywie, red. A. Karpińska, K. Borawska-Kalbarczyk, Difin, Warszawa 2011, s. 191-208.

20 Badaniami objęto 176 studentów I roku kierunku pedagogika na Wydziale Pedagogiki i Psychologii Uniwersytetu w Białymstoku. Projekt realizowała Anna Sztachelska w roku akademickim 2013/2014.

${ }^{21}$ Por. m.in. T. Pilch, T. Bauman, Zasady badań pedagogicznych. Strategie badań ilościowych i jakościowych, Żak, Warszawa 2001. 


\section{Doświadczanie niepowodzeń szkolnych przez obecnych studentów}

$\mathrm{Na}$ podstawie przeprowadzonych badań stwierdzono, że studenci kierunku pedagogika $\mathrm{w}$ niewielkim stopniu dotknięci byli problemem niepowodzeń szkolnych na wcześniejszych etapach edukacyjnych. Biorac pod uwage ich średnia ocen oraz samoocenę jako uczniów, stwierdzić wręcz należy, iż w badanej próbie nie wystapiły wymierne niepowodzenia wskaźnikowane niską średnią ocen, gdyż w przedziale wysokich osiagnięć szkolnych (średnia ocen powyżej 4,0) sytuowało się $80 \%$ badanych $(80,11 \%)$, zaś pozostali, w ok. $20 \%$ deklarowali uzyskiwanie średniej 3,9-3,0. W korelacji ze stosunkowo wysoka średnia ocen pozostaje samoocena badanych. Ponad połowa uważa, że była dobrymi uczniami, a prawie $19 \%(18,75 \%)$ spostrzega się w roli bardzo dobrych uczniów. Zaledwie $22 \%(22,16 \%)$ to uczniowie przeciętni. Do trudności w uczeniu się i sprawiania problemów wychowawczych przyznały się pojedyncze osoby (odpowiednio: 0,57 i 0,57\%). Charakterystyczne jest, że żaden student nie określił się mianem ucznia słabego. Zatem wyniki badań wycinkowych nie potwierdzaja powszechnie panujacej opinii o słabym przygotowaniu kandydatów na studia (jeśli mierzyć owo przygotowanie ich średnią ocen na wcześniejszych etapach edukacyjnych). Okazuje się bowiem, że studia na kierunku pedagogika podejmują w zdecydowanej większości uczniowie dobrzy i bardzo dobrzy, o wysokiej i bardzo wysokiej średniej ocen. Na studia trafiają również uczniowie przeciętni, z niższą średnią ocen (poniżej 4,0). Stanowią oni ok. $1 / 4$ studentów I roku (ok. 20\%). To w tej grupie, choć nie tylko, można spodziewać się występowania na niższych etapach edukacyjnych przejściowych trudności i niepowodzeń szkolnych, nierzadko ukrytych, które wprost nie zostały zadeklarowane przez respondentów, lecz dalsza procedura badawcza pozwoliła na ich zidentyfikowanie.

\section{Przejawy i obszary ewentualnych niepowodzeń szkolnych obecnych studentów}

Ustalono, że prawie co piąty student $(19,32 \%)$ doznawał trudnych sytuacji szkolnych. Ich ewentualne niepowodzenia przejawiały się spo- 
radycznie w powtarzaniu klasy $(0,57 \%)$, zmianie szkoły/klasy $z$ powodu złych wyników w nauce lub niepoprawnego zachowania (0,57\%), częstym otrzymywaniu ocen niedostatecznych $(1,14 \%)$, a co za tym idzie - niskiej średniej ocen $(1,70 \%)$, a także korzystaniu z zespołów dydaktyczno-wyrównawczych $(4,55 \%)^{22}$, co może świadczyć o pojawianiu się braków i luk w opanowywanym materiale nauczania i konieczności ich uzupełniania, by zapobiec ich nawarstwianiu się prowadzacym do niepowodzeń względnie trwałych. Tych ewidentnych w postaci drugoroczności, promocji warunkowej, nie mówiąc o odsiewie czy odpadzie szkolnym, w zasadzie nie odnotowano (poza pojedynczym przypadkiem powtarzania klasy). Charakterystyczną okolicznością ujawnioną w badaniach były częste nieobecności w szkole, które moga sprzyjać powstawaniu zaległości w nauce, tworzac pożywkę dla niepowodzeń. Problem niskiej frekwencji dotyczył ponad $10 \%(10,80 \%)$ uczniów. Ciekawe jest, że sytuacja ta pojawiała się $\mathrm{z}$ tą samą częstotliwością zarówno $\mathrm{w}$ grupie uczniów przeciętnych $(14,29 \%)$, jak i bardzo dobrych $(14,29 \%)$.

Fakt, że obecni studenci nie doznawali niepowodzeń szkolnych w ich trwałej postaci, nie świadczy o zupełnym braku trudności w nauce i przejściowych problemów, $z$ którymi przychodzi się borykać uczniom w różnym natężeniu i w różnych obszarach szkolnej przestrzeni - w wymiarze dydaktycznym i wychowawczym. Badania ujawnily, że najwięcej trudności studentom w czasach szkolnych sprawiały umiejętności rachunkowe wskazywane jako złożona kompetencja przez niemal 44\% respondentów (nieco mniej, ale niewiele, wśród uczniów bardzo dobrych - 38,1\%). Znacznie mniej osób zgłasza trudności z pisaniem prac stylistycznych - ok. 7\% $(6,82 \%)$ (wszak to studia humanistyczne!), przy czym problem ten dwukrotnie częściej eksponuja uczniowie przeciętni (11,43\%) niż dobrzy $(6,67 \%)$, zaś bardzo dobrych zdaje się to nie dotyczyć. Do kłopotów z logicznym myśleniem przyznaje sie ponad 5\% (5,68\%) badanych. Co ciekawe, sa to głównie uczniowie dobrzy. Zaś problemy z ortografią deklaruje zaledwie 4\%

22 Wiarygodność tych danych budzi uzasadnione wątpliwości, gdyż studenci zapytani wprost w dalszej części badań o korzystanie z zajęć wyrównawczych podczas nauki w szkole średniej złożyli zupełnie inne deklaracje, wskazując w 26,70\% na udział w zajęciach wyrównawczych (głównie $z$ matematyki, ale i z języka angielskiego oraz z języka polskiego). Te dane daja zupełnie inny (większy) obraz skali ewentualnych trudności i niepowodzeń szkolnych obecnych studentów oraz potrzeb w zakresie pracy zapobiegawczej. 
Studentów - w tym przypadku dwukrotnie częściej dotyczą one uczniów przeciętnych $(8,57 \%)$ i nie występują w grupie uczniów bardzo dobrych.

Swoistą trudnością zgłaszana przez respondentów okazały się prace domowe, których odrabianie było problemem dla prawie 11\% (10,78\%) badanych. Co intrygujące, eksponowanym ponad dwukrotnie częściej przez uczniów bardzo dobrych $(19,48 \%)$ niż przeciętnych $(8,57 \%)$. Warto też zauważyć, że niemal $1 / 3$ studentów $(28,98 \%)$ twierdzi, że nie miała żadnych problemów w nauce. Tak deklaruje również $1 / 4$ studentów, których przeciętna średnia ocen w okresie szkolnym $(3,9-3,0)$ wskazywałaby jednak na pojawianie się przejściowych trudności.

Badania ujawnily też swoiste obszary występowania cząstkowych ocen niedostatecznych będących wskaźnikiem niepowodzeń przejściowych. Najczęściej takie oceny otrzymywali respondenci z powodu braku pracy domowej - 39\% wskazań. Prawie 30\% (28,18\%) stanowiły oceny z odpowiedzi i nieco mniejszy udział w kumulowaniu się ocen najniższych miały prace kontrolne, sprawdziany, testy. Zajęcia praktyczne w zasadzie nie generowały słabych ocen $(1,82 \%)$. Ponad $5 \%$ studentów przyznaje się do częstego otrzymywania ocen negatywnych $z$ powodu niestosownego zachowania.

\section{Przyczyny trudności w nauce}

Osiągnięcia szkolne warunkowane są wieloma czynnikami. Najczęściej ujmuje się je w trzech głównych grupach tworzacych uwarunkowania społeczno-ekonomiczne, biopsychiczne i pedagogiczne. Zdecydowana większość studentów $(69,09 \%)$ eksponuje znaczenie czynników tkwiących w pracy nauczyciela i organizacji szkoły. $1 / 4$ respondentów $(24,55 \%)$ wskazuje na sprawczy charakter czynników tkwiących w uczniu, a jedynie niewiele ponad 6\% w środowisku rodzinnym upatruje głównej przyczyny niskich wyników w nauce.

Przyglądając się bardziej szczegółowo deklaracjom studentów, według największej liczby badanych (34,30\%) przyczyną ich słabszych ocen mogły być niewłaściwe metody nauczania i niewłaściwa postawa nauczyciela. W dalszej kolejności sytuuja lenistwo $(15,57 \%)$, brak zdolności $(13,15 \%)$, ale i brak motywacji (10,03\%). Częściej wskazuja jednak na czynnik od nich niezależny w postaci trudnych, niezrozumiałych treści $(15,57 \%)$. Sporadycznie obwiniają za własne niepowodzenia kolegów, do- 
strzegajac ich zły wpływ (6,57\%), a w jednostkowych przypadkach - rodzinę, wskazujac na brak zainteresowania i pomocy ze strony rodziców $(3,46 \%)$ oraz niesprzyjająca atmosferę życia rodzinnego $(2,08 \%)$. Zatem badania potwierdziły, że niezadowalajace wyniki w nauce w opinii obecnych studentów były najczęściej spowodowane przyczynami pedagogicznymi związanymi głównie $z$ brakiem zainteresowania ze strony nauczycieli oraz niewłaściwie dobranymi metodami nauczania. Pozostałe czynniki mogły mieć pośredni wpływ na pojawiające sie problemy, jednak sami badani zdecydowanie stwierdzili, że to czynniki tkwiące w pracy szkoły i nauczycieli sa najbardziej odpowiedzialne za ich edukacyjne porażki.

\section{Formy zapobiegania niepowodzeniom szkolnym}

Uzyskane wyniki potwierdzaja, iż wciąż przedmiotem sprawczym ewentualnych niepowodzeń jest matematyka. Nie dziwi zatem fakt, że ponad $1 / 4$ respondentów $(25,57 \%)$ korzystała $z$ zajęć wyrównawczych $z$ tego przedmiotu. Brali w nich udział również uczniowie dobrzy (25\%), a nawet bardzo dobrzy (19,05\%). Obecni studenci uczęszczali też na dodatkowe zajęcia organizowane przez szkołę w zakresie języka angielskiego - prawie 4\% $(3,98 \%)$ oraz $w$ jednostkowych przypadkach $-z$ języka polskiego $(0,57 \%)$.

Generalnie $z$ badań wynika, że ponad $1 / 4$ obecnych studentów $(26,70 \%) \mathrm{w}$ czasie nauki na niższych etapach edukacyjnych korzystała $z$ tej formy zapobiegania niepowodzeniom szkolnym, jaka sa oferowane przez placówki zajęcia wyrównawcze. Odnotować wypada, że wśród uczniów bardzo dobrych (prawie 20\%) i dobrych (ponad 26\%) ta propozycja pracy pozalekcyjnej znalazła również swoich odbiorców.

\section{Niepowodzenia szkolne a losy edukacyjne}

Badania wykazały, że doznawane trudności w nauce $\mathrm{w}$ ocenie respondentów miały charakter przejściowy i nie wpłynęły znacząco na ich dalsze losy edukacyjne. Ponad 43\% (43,18\%) studentów wręcz uważa, że nie maja one zwiazku $z$ ich obecna sytuacja edukacyjna. Taka opinię wyraża ponad połowa studentów $(54,29 \%)$, którzy byli przeciętnymi uczniami. Jednakowoż zdaniem prawie połowy badanych $(49,43 \%)$ do- 
świadczane trudności szkolne w pewnym stopniu miały wpływ na decyzje dotyczące wyboru dalszej ścieżki edukacyjnej. Częściej tak skłonni sa uważać uczniowie dobrzy (55\%) i bardzo dobrzy $(47,62 \%)$ niż przeciętni $(31,43 \%)$. Natomiast ponad 7\% (7,39\%) studentów twierdzi, że doznane w nauce trudności zdecydowanie wpłynęły na ich losy edukacyjne. Dwukrotnie częściej takie zdanie wyrażaja rzecz jasna ci, którzy byli przeciętnymi uczniami (14,29\%), ale warto odnotować, że determinujacy wpływ przejściowo niekorzystnej sytuacji szkolnej eksponuje także prawie 10\% uczniów o najwyższej średniej ocen.

$Z$ faktu, iż badani są obecnie studentami, można wnosić, że ewentualne niepowodzenia w nauce były dla nich bardziej motywacja do działania niż porażka podcinająca skrzydła, zniechęcająca do podejmowania wysiłku. Rzeczywiście w relacji ponad 37\% $(37,5 \%)$ badanych napotykane trudności w nauce wyzwalały chęć do ich przezwyciężenia. Na motywujacy charakter niepowodzeń wskazują głównie uczniowie bardzo dobrzy $(52,38 \%)$. Ale sa i tacy, dla których niepowodzenie to porażka, brak wiary we własne możliwości, a w konsekwencji niechęć do nauki. Taką sytuację zgłasza prawie 14\% (13,63\%) badanych, $z$ dominacja uczniów dobrych $(15,83 \%)$ i przeciętnych $(11,43 \%)$. Wart zastanowienia jest wskaźnik dotyczący prawie 49\% studentów, którzy twierdza, że niepowodzenia szkolne nie zostawiły śladu w ich życiu, tym bardziej że taką opinię kreują częściej studenci, którzy byli uczniami przeciętnymi (54,29\%). Może edukacja akademicka rzeczywiście w obecnym wydaniu nie wymaga szczególnie zbyt wiele, a w sytuacji, gdy studentem może zostać każdy, kto „zapisze się" na studia, deficyty w wiedzy i umiejętnościach wyniesione ze szkoły średniej nie maja większego znaczenia dla przebiegu „studiowania”.

Zreszta znamienne jest, że co piąty student $(19,89 \%)$ wybrał kierunek pedagogika, gdyż „łatwo było dostać się na te studia”. Dwukrotnie częściej taki motyw podają studenci, którzy byli przeciętnymi uczniami. Do refleksji skłaniaja też następujące dane: dla 2,84\% respondentów pedagogika była alternatywą, gdyż nie dostali się na kierunek pierwszego wyboru (m.in. położnictwo, kosmetologia); dla 1,74\% pedagogika jest dopełnieniem innego studiowanego kierunku; 1,14\% wybrało studia ze względu na miasto, tyle samo ze względu na znajomych, a 1,70\% nie wiedziało, jaki kierunek wybrać, więc... „wypadło na pedagogikę”. 
Dla przeciwwagi warto odnotować i bardziej wartościowe motywy, którymi kierowali się badani studenci przy wyborze szkoły wyższej, tym bardziej że to one dominują w rejestrze deklarowanych okoliczności. Niemal co drugi respondent (46,59\%) wybrał kierunek pedagogika, gdyż jest to jego pasja i to właśnie $z$ nią wiąże swoja przyszłość. Dla co czwartego studenta $(24,43 \%)$ pedagogika też jest pasja, ale nie wie, czy jego przyszłość zawodowa będzie z nia związana. Te 70\% studentów-pasjonatów dyscypliny naukowej przywraca wiarę w młodego człowieka!

\section{Jacy są studenci pedagogiki?}

A jacy są badani studenci pod względem cech socjodemograficznych; jaka jest ich rodzina pochodzenia i kondycja biopsychiczna?

$Z$ wycinkowej eksploracji wynika, że pedagogikę studiuja głównie kobiety. W badanej próbie stanowia ponad 90\% (92,05\%). Najliczniejszą grupę na I roku tworza 19- i 20-latkowie, a zatem osoby, które podjęły studia tuż po ukończeniu szkoły maturalnej $(78,98 \%)$. Pozostali studenci mają odpowiednio $21(14,77 \%), 22(3,41 \%)$ i $23(2,84 \%)$ lata. Niewykluczone jest, że biografie edukacyjne tych nieco ponad $20 \%$ studentów I roku moga być naznaczone jakąs postacia niepowodzeń szkolnych, które wydłużyły/opóźniły ich cykl kształcenia przedakademickiego. Bohaterowie prezentowanej narracji w zdecydowanej większości sa absolwentami liceów ogólnokształcących $(89,20 \%)$. Zaledwie ok. 8\% badanych ukończyło technikum, zaś liceum profilowane ok. 3\%. 1/3 studentów $(32,95 \%)$ pochodzi ze wsi. Ponad $80 \%$ badanych wychowywało się w rodzinie pełnej. Osiagnięcia szkolne pozostałych, mimo że struktura ich rodzin była zaburzona, mieszcza się we wszystkich przedziałach średniej ocen $\mathrm{w}$ stopniu proporcjonalnym do sytuacji kolegów $\mathrm{z}$ rodzin pełnych, co wskazuje na brak zwiazku statystycznie istotnego między struktura rodziny a wynikami w nauce. Podobny wniosek wynika $z$ analizy dzietności rodzin pochodzenia. Badani studenci zdecydowanie częściej wychowywali się w rodzinach mało licznych, posiadając jedno $(47,16 \%)$ lub dwoje $(25 \%)$ rodzeństwa. Rodziny wielodzietne (czworo dzieci i więcej) stanowiły ok. 20\%. Jedynaków, którzy notabene byli uczniami bardzo dobrymi i dobrymi, jest wśród respondentów prawie $10 \%$. Badani ciesza się na ogół dobrym $(44,89 \%)$, a nawet bardzo dobrym $(41,48 \%)$ stanem zdrowia. Sa 
też osoby, które oceniaja swoje zdrowie jako „średnie” $(9,66 \%)$ oraz często chorują (3,98\%). Tę ostatnia kategorię, co ciekawe, dwukrotnie częściej deklaruja studenci, którzy byli bardzo dobrymi uczniami. A zatem zły stan zdrowia nie zawsze idzie w parze $z$ niepowodzeniami szkolnymi. Warto zwrócić uwagę na często występujące u młodych ludzi zaburzone funkcjonowanie narządów zmysłowych, które w porę niekompensowane może być pożywka dla trudności w nauce. Aż co trzeci badany student posiada wadę wzroku. Na podstawie analizy wyników badań można wnosić, że nie pozostaje ona w zwiazku z osiagnięciami szkolnymi, gdyż uczniowie $z$ każdego przedziału średniej ocen zgłaszaja ten problem w podobnym wymiarze. Zdarzaja się też sporadycznie zaburzenia narząu słuchu $(2,27 \%)$, mowy $(2,27 \%)$ i motoryki $(0,57 \%)$. Charakterystyczne, że nie dotyczą one uczniów $z$ najniższą średnią ocen.

Wobec narastajacego problemu dysfunkcji społecznych warto przyjrzeć się temu problemowi poprzez pryzmat doświadczeń badanych studentów. Prawie co dziesiąty student pedagogiki był jako uczeń diagnozowany w poradni psychologiczno-pedagogicznej. Trzykrotnie częściej takie deklaracje składaja uczniowie przeciętni. Powody, dla których przechodzili badania, były różne. $Z$ uwagi na specyfikę kierunku studiów niepokoić powinien fakt, że mamy studentów - wprawdzie niewielu (ok. 4\%), $z$ orzeczona dysleksją, dysgrafią i dysortografią.

\section{Osiągnięcia i trudności w studiowaniu}

Jak wcześniej ustalono, badani w 80\% rekrutują się spośród uczniów dobrych i bardzo dobrych (średnia ocen powyżej 4,0). Ponad połowa uważa, że była dobrymi uczniami, a prawie 19\% (18,75\%) postrzega się w roli bardzo dobrych uczniów. Zaledwie 22\% (22,16\%) to uczniowie przeciętni. Warto przeanalizować, jak respondenci postrzegają się w roli studentów. W zasadzie studiowanie nie zmieniło ich samooceny, bowiem wciaż ponad połowa $(52,27 \%)$ uważa się za dobrych studentów, a 12,5\% wręcz za bardzo dobrych. Ten ostatni wskaźnik jest nieco niższy w stosunku do deklaracji czynionych w odniesieniu do osiagnięć na niższych etapach kształcenia i pozostaje w związku z częstszym deklarowaniem kategorii „jestem studentem przeciętnym” - tak twierdzi prawie 1/3 respondentów $(32,95 \%$, tj. o 10 punktów procentowych więcej niż podczas samooceny 
w roli ucznia). Nadal żaden student nie identyfikuje się z kategoria „słaby”, „mający trudności w studiowaniu”, „sprawiający trudności wychowawcze”.

\section{$* * *$}

Reasumując, należy podkreślić, że studenci pedagogiki, którzy byli przedmiotem wieloaspektowych eksploracji zmierzajacych do ustalenia miejsca niepowodzeń szkolnych w ich edukacyjnej biografii i ich ewentualnego wpływu na losy życiowe badanych, to grupa młodych ludzi, których los nie został naznaczony niepowodzeniami szkolnymi.

Dla większości szkolne porażki - jeśli miały miejsce - stały się bodźcem do nauki, zaś „niepowodzenie - jak mawiał Henry Ford - sposobnością do użycia inteligencji w dalszym działaniu".

Słowa kluczowe: niepowodzenia szkolne, konsekwencje opóźnień $w$ nauce, osiagnięcia i trudności $w$ studiowaniu

\section{SCHOOL FAILURES IN PEDAGOGY STUDENTS' RETROSPECTION}

\section{Summary}

The article presents the results of a research project conducted among first year students of pedagogics. It aim was to explore education history of current students, with an attempt of recognition of their possible school failures, as well as an effort to outline the effect of those failures on participants lives, especially on the decision concerning the choice of their academic path. The presented narration is situated in a trend of the author`s biographical research, aiming at the determination of prospective difficulties and failures faced by students.

Keywords: school failure, academic achievements, difficulties and problems 


\section{Janusz Ślusarski}

Wyższa Szkoła Oficerska Sił Powietrznych

\section{Inteligencja społeczna nauczycieli akademickich a ich ukryte teorie na temat osobowości studentek/studentów}

\section{Wprowadzenie}

Autor najnowszego Stownika psychologii, Norbert Sillamy, definiujac pojęcie „inteligencja” proponuje za Edwardem Lee Thorndikiem by rozróżniać co najmniej „wielkie jej typy:

- Inteligencję abstrakcyjna, czyli konceptualną, charakteryzującą się zdolnością do stosowania materiału werbalnego i symbolicznego.

- Inteligencje praktyczna, ujawniająca się przez działania w sferze konkretów, np. gdy trzeba manipulować przedmiotami.

- Inteligencję społeczna, warunkujacca zrozumienie sytuacji społecznych i łatwość porozumienia się z ludźmi"1.

Dotychczas stworzono szereg koncepcji inteligencji, które szczegółowo zostały omówione m.in. w publikacjach takich autorów, jak: Joy Paul Guilford, Hans Jürgen Eysenck, Bolesław Hornowski, Czesław Nosal, Martin Seligman, Robert Sternberg czy Jan Strelau.

Według Anny Piotrowskiej na inteligencję społeczną składają się następujące zdolności:

a) zdolność rozpoznawania emocji, myśli, pragnień, intencji innych osób;

1 M. Sillamy, Stownik psychologii, tłum. K. Jarosz, Ksiażnica, Warszawa 1994, s. 104-105.

2 A. Piotrowska, Techniki pomiaru inteligencji społecznej, „Psychologia Wychowawcza” 1993, nr 4, s. 342-349; eadem, Pomiar inteligencji społecznej w psychologii osobowości i w psychologii społecznej, „Psychologia Wychowawcza” 1994, nr 2, s. 158-169. 
b) zdolność określania cech osobowości na podstawie obserwacji zachowań i wypowiedzi, czyli umiejętność wnioskowania o bardziej trwałych cechach czy dyspozycjach;

c) zdolność rozumienia interakcji czy też mówiąc inaczej, umiejętność rozpoznawania typu relacji zachodzacych między ludźmi;

d) zdolność powiązania danej sytuacji (czy interakcji) z innymi, a więc umiejętność interpretowania określonej sytuacji (interakcji) jako elementu w ciagu wydarzeń, a co za tym idzie - rozumienia, jakich zdarzeń jest następstwem, i przewidywania, jakie będa jej konsekwencje;

e) zdolność odpowiedniego zachowania się w sytuacjach społecznych.

Zdaniem Daniela Golemana jednostka posiadająca wysoki poziom zdolności społecznych dobrze rozpoznaje i interpretuje różne informacje społeczne, zna normy moralne i etyczne, wie, jak należy się zachować w różnych sytuacjach (świadomość społeczna), może jednak nie umieć zastosować tej wiedzy i umiejętności w swoim codziennym życiu (sprawność społeczna). Na umiejętność wykorzystania tej wiedzy wpływaja bowiem zmienne inne niż tylko intelektualne (np. osobowościowe) ${ }^{3}$.

$\mathrm{W}$ tym miejscu warto jeszcze dodać, że niektóre $z$ wyodrębnionych przez psychometrów w ramach inteligencji społecznej zdolności są też od lat przedmiotem zainteresowań w badaniach psychologii rozwojowej, poznawczej i osobowości ukierunkowanych na poszukiwanie efektywnego funkcjonowania społecznego. W ramach takiego sposobu podejścia omawiane zdolności opisuje się m.in. jako np.:
a) zdolność empatii;
b) zdolność do dekodowania komunikatów niewerbalnych;
c) zdolność do decentracji interpersonalnej, czyli przyjmowania w sy- tuacjach społecznych innych niż własny punkt widzenia i koordy- nowania ich ${ }^{4}$;
d) zdolność do dokonywania ocen moralnych ${ }^{5}$.

3 D. Goleman, Inteligencja społeczna, tłum. A. Jankowski, Rebis, Poznań 2007.

4 P. Mlicki, Decentracja interpersonalna jako przedmiot badań psychologicznych, „Psychologia Wychowawcza” 1989, nr 30, s. 403-414.

5 A. Matczak, Diagnoza intelektu, Wyd. PAN, Warszawa 1994. 
Jako szczególnie ważny wskaźnik inteligencji społecznej jest często traktowana empatia ${ }^{6}$. Charakteryzuje się ją często jako trójelementowe zjawisko psychiczne. Pierwszym składnikiem empatii jest zdolność do rozpoznawania i rozróżniania emocji, które polegają na umiejętności wykorzystywania właściwych informacji w celu określenia i zidentyfikowania emocji i uczuć, które sa doznawane przez nas, a także przeżywane przez inne osoby. Drugim składnikiem jest zdolność do przewidywania oraz przyjmowania ról pełnionych przez inne osoby. Proces ten polega na umiejętności zrozumienia tego, że druga osoba może postrzegać oraz interpretować sytuację w odmienny sposób, oraz na umiejętności przyjęcia i doświadczenia punktu widzenia drugiej osoby. Trzeci zaś składnik to emocjonalna odpowiedzialność, co oznacza zdolność dzielenia, czyli współprzeżywania emocji drugiego człowieka przy jednoczesnym zachowaniu świadomości, odmienności i odrębności swoich własnych przeżyć. Dojrzałe, a także zróżnicowane przeżywanie empatii wymaga spełnienia wszystkich trzech wymienionych warunków. Możemy stwierdzić, iż dwa pierwsze bywaja spełnione już w przeżyciach dziecięcych. Sa to jednak wstępne warunki, które pozwalają właściwie przeżywać empatię i nie urzeczywistniaja przeżycia empatycznego w pełny i dojrzały sposób. Dojrzałe doznanie empatii wymaga spełnienia warunku trzeciego, tzn. współprzeżywania $z$ druga osobą bez utraty świadomości swoich własnych przeżyć 7 .

W literaturze przedmiotu występują różne definicje empatii. Wiadomo jednak, iż ważna cechą empatii jest to, że wykazuje ona pozytywną rolę $\mathrm{w}$ procesie rozwoju emocjonalno-społecznego jednostki. Empatia warunkuje zachowania altruistyczne, pozytywnie wpływa na proces kontrolowania i hamowania agresji oraz jest zwiąana $z$ tendencja do współpracy ${ }^{8}$.

Dobrym podsumowaniem dotychczasowych rozważań na temat inteligencji społecznej wydaje się dwuaspektowy jej podział przedstawiony

6 S. Bonino, Empatia a inteligencja, cechy osobowości i temperamentu, „Psychologia Wychowawcza" 1994, nr 5.

$7 \quad$ A. Węgliński, Opracowanie Kwestionariusza Rozumienia Empatycznego innych lu$d z i$ (KRE), „Wzorce Psychologiczne” 1983, nr 4.

8 M. Kliś, J. Kossewska, Empatia a inteligencja, cechy osobowości i temperamentu, „Psychologia Wychowawcza” 1994, nr 5. 
przez Annę Matczak. Wyróżnia ona za Thorndikiem dwa aspekty inteligencji społecznej:

a) związany $z$ rozumieniem ludzi - wymienia tu takie zdolności, jak: zdolność rozpoznawania stanów emocjonalnych, rozumienia motywów i intencji innych ludzi, przewidywania ich zachowań oraz oceny sytuacji społecznych;

b) zwiazany $z$ adekwatnym działaniem $\mathrm{w}$ sytuacjach społecznych wymienia tu takie zdolności, jak: zdolność przyswajania sobie i rozumienia reguł społecznych (zarówno ogólnych norm moralnych, jak i bardziej szczegółowych zasad czy przepisów dotyczących zachowań w określonego typu sytuacjach czy związanych $z$ pełnieniem określonych ról), planowania działań służących rozwiąyywaniu konkretnych problemów społecznych (w tym m.in. adekwatnego wykorzystania posiadanej wiedzy o regułach, godzeniu reguł sprzecznych, znajdowania rozwiąań kompromisowych) oraz zdolność do realizowania tych planów (czyli rzeczywistego sterowania sytuacjami społecznymi) ${ }^{9}$.

Począwszy od końca lat pięćdziesiątych, punkt ciężkości badań przesunał się w kierunku problemu samego mechanizmu formowania obrazu spostrzeganego człowieka, tj. natury tego procesu. Powszechnie uważa się, iż początek temu nurtowi badań dał Solomon Asch, który postawił pytanie odnoszące się do struktury obrazu spostrzeganego człowieka i czy ogólne wyobrażenie jakiejś postaci jest suma jej atrybutów, czy też figura, której każda ze składowych ma inne znaczenie w zależności od towarzyszących jej pozostałych składowych. W badaniach, które zdaniem Ascha potwierdziły druga $z$ tych możliwości, zostało dowiedzione, że sa takie cechy, od których w szczególnym stopniu zależy ogólne wyobrażenie spostrzeganego człowieka - nazwał je centralnymi. W zależności od tego, jakie jest nasilenie cechy centralnej, obraz postaci przybiera zasadniczo różny kształt mimo takiego samego zbioru pozostałych atrybutów. Choć liczne badania wielokrotnie potwierdzily istnienie samego zjawiska opisa-

9 A. Matczak, Diagnoza intelektu. 
nego przez Ascha, to sporo późniejszych badań nie przemawiało za słusznościa jego gestaltowskiej interpretacji ${ }^{10}$.

Przeciwko niej świadcza przede wszystkim liczne eksperymenty weryfikujące tzw. model średniej. Model ten zakładał, że to, w jakim stopniu ogólna impresja spostrzeganego człowieka zawiera określony czynnik, da się wyjaśnić ważną średnią nasycenia tym czynnikiem atrybutów, za pośrednictwem których przedstawiono dana osobę obserwatorom. Osobom badanym prezentowano zestawy przymiotników opisujące jakąś postać, nasycone w różnym stopniu określonym czynnikiem, np. cechą wyraźnie wartościowaną albo czynnikiem mocy spostrzeganej u opisywanej postaci, następnie proszono o przedstawienie obrazu opisywanej postaci, aby przekonać się, w jakim stopniu będzie on nasycony danym czynnikiem ${ }^{11}$. Okazywało się, że stopień nasycenia obrazu tym czynnikiem jest średnia nasycenia nim składowych obrazu, co sugeruje zupełnie inny pogląd na strukturę całościowego wyobrażenia spostrzeganej postaci niż zawarty w gestaltowskiej interpretacji Ascha. Im bardziej cechy bodźcowe są ze sobą niezgodne ze względu na ewaluację, a także im bardziej zróżnicowane sa ze względu na ważność oraz im jest ich więcej, tym słabiej pasować będzie do takich sytuacji model średniej ${ }^{12}$.

Istnienie związku między struktura „ukrytej teorii” i „strukturą odpowiadającej jej rzeczywistości” jako pierwsi wykazali C.H. Lay i Douglas Jackson. Zmierzyli oni strukturę ukrytej osobowości, posługując się skalowaniem wielowymiarowym. Na podstawie tej metody można sądzić, że ludzie poprzez obserwację ucza się przewidywać prawdopodobieństwo współwystępowania poszczególnych właściwości. Ukryta teoria osobowości zawiera w sobie zawsze określoną koncepcję ludzkiej natury, chociażby taką, iż „ludzie $x$ są zwykle $y$, a rzadziej $z^{13}$. Można więc oczekiwać, że pozostaje ona $\mathrm{w}$ związu $z$ osobowościa spostrzegajacego, a szczególnie z tymi jej cechami, które wiąża się ze sposobem kontaktowania się z ludź-

${ }^{10}$ S.E. Asch, Forming Impressions of Personality, „Journal of Abnormal and Social Psychology" 1946, no. 41, s. 258-290.

${ }^{11}$ Ibidem.

${ }^{12}$ P. Lewicki, Zjawisko ukrytej teorii osobowości $w$ procesie spostrzegania społecznego, w: Psychologia spostrzegania społecznego, red. M. Lewicka, Książka i Wiedza, Warszawa 1985.

\section{${ }^{13}$ Ibidem.}


mi. Łatwo wykazać, że ludzie różnią się ukrytymi teoriami osobowości, ale niewielkim sukcesem zakończyły się próby poszukiwania związków między tymi różnicami a tradycyjnymi zmiennymi osobowościowymi. Badaczom generalnie nie powiodły się poszukiwania osobowościowych lub biograficznych korelatów ukrytej teorii osobowości ${ }^{14}$.

Ukryta teoria osobowości służy uzupełnieniu braków danych, dlatego silniej ujawnia się tam, gdzie obserwator mniej zna obserwowanego. Nikt chyba nie kwestionuje tezy, że ukryta teoria osobowości jest determinowana przez obserwacje najbliższego otoczenia i kontakty społeczne; prawdę tę zawieraja nawet popularne książki na temat percepcji osób. Podsumowując, można stwierdzić, że niska efektywność dotychczasowych badań nad ukryta teoria osobowości dla wyjaśnienia zachowań wynika zapewne $z$ faktu, że badano przede wszystkim to, czy istnieje jakieś swoiste nastawienie do stałego wyboru określonej koncepcji człowieka, nie zaś strukturę $\mathrm{w}$ istocie determinująca formułowanie obrazów spostrzeganych osób ${ }^{15}$.

Wydaje się więc, że tych kilka przedstawionych powyżej uwag pozwala na sformułowanie następujacej hipotezy - nauczyciele akademiccy o wyższym poziomie inteligencji społecznej trafniej spostrzegaja swoich studentów, a tym samym ich ukryte teorie na temat osobowości studentek/studentów sa trafniejsze. Potwierdzenie lub odrzucenie tak sformułowanej hipotezy wymagało przeprowadzenia badań na wybranej grupie nauczycieli szkoły wyższej. Celem tych badań było więc ustalenie zwiąku pomiędzy poziomem inteligencji społecznej badanych nauczycieli akademickich a prezentowanymi przez nich ukrytymi teoriami na temat osobowości studentek/studentów. W związku $z$ tak określonym celem badań udzielono także odpowiedzi na następujące szczegółowe problemy badawcze:

1. Jaki jest poziom inteligencji społecznej badanych nauczycieli akademickich?

2. Jakie najczęściej ukryte teorie prezentuja badani nauczyciele akademiccy na temat osobowości studentek/studentów?

\footnotetext{
${ }^{14}$ Ibidem.

${ }^{15}$ Ibidem.
} 
3. Czy występuje i w jakim zakresie zależność pomiędzy poziomem inteligencji społecznej badanych nauczycieli akademickich a prezentowanymi przez nich ukrytymi teoriami na temat osobowości studentek/studentów?

Do badania inteligencji społecznej wykorzystano opracowane przez pracowników naukowych Wydziału Psychologii Uniwersytetu Warszawskiego narzędzia badawcze, tzn. dwa testy z Baterii Testów APIS-Z: Test Zachowania i Test Historyjki ${ }^{16}$. Bateria Testów APIS- $Z$ jest testem inteligencji ogólnej przeznaczonym do badań grupowych, mierzacym cztery typy zdolności: abstrakcyjno-logiczne, werbalne, wzrokowo-przestrzenne i społeczne. Bateria Testów APIS- $Z$ składa się $z$ ośmiu różnych testów. Do pomiaru zdolności społecznych stosowane sa dwa spośród nich, tzn.: nr 1 - Test Zachowania i nr 8 - Test Historyjki ${ }^{17}$. Z kolei do określenia, jakimi ukrytymi teoriami osobowości swoich studentek/studentów posługuja się badani nauczyciele akademiccy, wykorzystano narzędzie, które jest adaptacją Skali LPC (Najbardziej i Najmniej Preferowanego Współpracownika) opracowanej przez Freda Edwarda Fiedlera ${ }^{18}$. Składa się ona $z$ dwóch zasadniczych części:

1. Pierwsza część to Skala Najbardziej Preferowanej/-go Studentki/ Studenta (NbPS). Składa się ona z 18 par przeciwstawnych sobie cech osobowości najbardziej preferowanej/-go studentki/studenta. Każdy $z$ badanych powinien pomyśleć o konkretnej studentce/konkretnym studencie, którym chciałby prowadzić zajęcia w przyszłości, być ich nauczycielem. Dla uzyskania najbardziej wiarygodnego wyniku badany powinien wpisać imię konkretnej studentki/konkretnego studenta i przez cały czas myśleć o tej osobie. Następnie posługując się skala punktowa (1-8), badany, analizując 18 par cech osobowości, dokonuje ich oceny na tej skali w kontekście tej konkretnej osoby.

2. Druga część to przeciwstawność części pierwszej - Skala Najmniej Preferowanej/-go Studentki/Studenta (NmPS), czyli każdy z badanych spośród 18 par cech osobowości wybranej/-go przez siebie kon-

${ }^{16}$ A. Matczak, A. Jaworowska, T. Szustrowa, A. Ciechanowicz, Bateria Testów APIS -Z. Podręcznik, Pracownia Testów Psychologicznych PTP, Warszawa 1995.

${ }^{17}$ Ibidem.

18 G. Kranas, Wybrane zagadnienia społecznej psychologii organizacji, t. II, Wyd. UW, Warszawa 1991. 
kretnej studentki/ konkretnego studenta w skali punktowej od 1 do 8 dokonuje oceny cech osobowości tej konkretnej osoby, $z$ która nie chciałby prowadzić zajęć w przyszłości, tzn. być jej nauczycielem.

Efekt końcowy testu to wyliczenie sum punktów uzyskanych w pierwszej i drugiej części testu. Następnie należy wyliczyć różnicę (NbPS NmPS) dla każdej z badanych osób ${ }^{19}$.

\section{Opis i interpretacja wyników badań}

Badania przeprowadzono w stuosobowej grupie nauczycieli akademickich pięciu uczelni lubelskich. Były to osoby w wieku od 30 do 46 lat (średnia wieku - 33 lata) $z$ wyższym wykształceniem pedagogicznym, o pedagogicznym stażu zawodowym od 6 do 20 lat pracy (średni staż pracy - 8 lat). Większość badanych to osoby zamężne i żonate, mające własne dzieci (najczęściej dwoje). Badania przeprowadzono w trakcie szkoleń metodycznych realizowanych w ramach wydziału lub instytutu danej uczelni. Miały one charakter grupowy i nie trwały dłużej niż 45 minut. Zebrane na tej podstawie dane przedstawiono w tabelach i na wykresach poniżej wraz $z$ ich opisem i interpretacja.

\section{A. Inteligencja społeczna badanych nauczycieli akademickich}

Tabela 1. Wartości średnich arytmetycznych i odchyleń standardowych charakteryzujące poziomy wskaźników inteligencji społecznej badanych nauczycieli akademickich

\begin{tabular}{|l|c|c|c|c|}
\hline \multirow{2}{*}{ Statystyka } & \multicolumn{2}{|c|}{ Test Zachowania } & \multicolumn{2}{c|}{ Test Historyjki } \\
\cline { 2 - 5 } & WS & WP & WS & WP \\
\hline $\begin{array}{l}\text { Średnia } \\
\text { arytmetyczna }\end{array}$ & 6,00 & 3,00 & 7,00 & 4,00 \\
\hline $\begin{array}{l}\text { Odchylenie } \\
\text { standardowe }\end{array}$ & 2,25 & 1,41 & 3,27 & 2,56 \\
\hline
\end{tabular}

Objaśnienia:

WS - wynik surowy,

WP - wynik przeliczony,

$\mathrm{TZ}$ - Test Zachowania,

$\mathrm{TH}$ - Test Historyjki

${ }^{19}$ S. Tokarski, Kierowanie ludźmi, Wyd. BWSH, Koszalin 1998. 


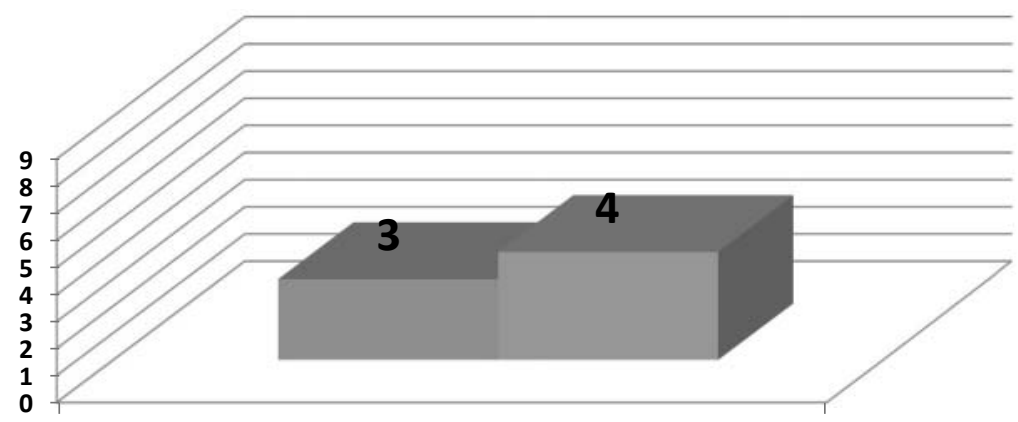

$\square \mathrm{TZ} \square \mathrm{TH}$

Objaśnienia:

$0,1 \ldots 9$ - skala przeliczeniowa,

wskaźniki inteligencji społecznej:

$\mathrm{TZ}$ - Test Zachowania,

TH - Test Historyjek.

Wykres 1. Rozkład graficzny wartości średnich arytmetycznych obliczonych na podstawie danych przeliczonych charakteryzujących poziomy wskaźników inteligencji społecznej badanych nauczycieli akademickich

$\mathrm{Na}$ podstawie danych umieszczonych w tabeli 1 oraz ich rozkładu graficznego przedstawionego na wykresie 1 można stwierdzić, że badana grupa nauczycieli akademickich charakteryzuje się przeciętnym poziomem inteligencji społecznej. Oba wskaźniki inteligencji społecznej po przeliczeniu średnich wyników surowych na wyniki przeliczone (stenowe) nieco się różnią (wartości średnich arytmetycznych dla $\mathrm{TZ}=3$ steny, a dla $\mathrm{TH}=4$ steny). Można więc sądzić, że badana grupa nauczycieli wykazała się mniejsza sprawnością w zakresie odpowiedniego zachowania się w danej sytuacji społecznej, a nieco większą w zakresie trafnego wiązania ze sobą różnych sytuacji społecznych ${ }^{20}$.

${ }^{20}$ A. Matczak, A. Jaworowska, T. Szustrowa, A. Ciechanowicz, Bateria Testów APIS-Z... 


\section{B. Ukryte teorie osobowości studentów w grupie badanych nauczycieli akademickich}

Tabela 2. Wartości średnich arytmetycznych i odchyleń standardowych charakteryzujące poziomy wskaźników mierzacych zakres występowania ukrytych teorii osobowości uczniów w grupie badanych nauczycieli akademickich

\begin{tabular}{|l|c|c|c|}
\hline \multicolumn{1}{|c|}{ Statystyka } & Nb PS & NmPS & NbPS - NmPS \\
\hline Średnia arytmetyczna & 117,0 & 50,0 & 68,0 \\
\hline $\begin{array}{l}\text { Odchylenie } \\
\text { standardowe }\end{array}$ & 10,4 & 10,1 & 17,7 \\
\hline
\end{tabular}

Objaśnienia:

NbPS - najbardziej preferowana/-y studentka/student,

NmPS - najmniej preferowana/-y studentka/student.

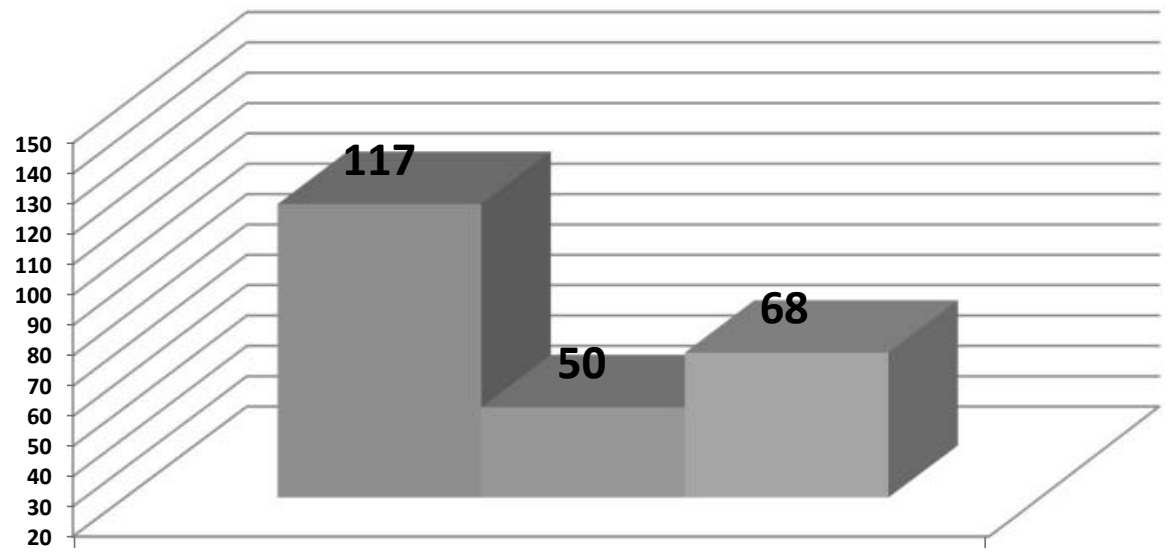

\section{NbPS NmPS NbPS-NmPS}

Objaśnienia:

$20,30, \ldots 150$ - skala punktowa zastosowana w narzędziu badawczym, NbPS - najbardziej preferowana/-y studentka/student,

NmPS - najmniej preferowana/-y studentka/student.

Wykres 2. Rozkład wartości średnich arytmetycznych obliczonych na podstawie danych surowych charakteryzujących poziomy wskaźników mierzących zakres występowania ukrytych teorii osobowości uczniów w grupie badanych nauczycielek 
$\mathrm{Na}$ podstawie danych umieszczonych w tabeli 2 oraz ich rozkładu graficznego przedstawionego na wykresie 2 można stwierdzić, że badana grupa nauczycieli akademickich ma tendencję do posługiwania się ukrytymi teoriami osobowości studentek/studentów. Przy czym wyniki te pokazują, że respondenci mają nieco większe tendencje do idealizowania najbardziej przez siebie preferowanej/-go studentki/studenta niż „dołowania” najmniej preferowanej/-go studentki/studenta (różnica między maksymalnym wynikiem, jaki może otrzymać NbPS oceniany na tej skali, tzn. 150 pkt, a otrzymanym wynikiem średnim dla tej grupy badanych nauczycieli, tzn. 117 pkt, równa jest 33 pkt; różnica między minimalnym wynikiem, jaki może otrzymać NmPU oceniany na tej skali, tzn. 20 pkt, a otrzymanym wynikiem średnim dla tej grupy respondentów, tzn. 50 pkt, równa jest 30 pkt).

C. Inteligencja społeczna badanych nauczycieli akademickich a występująca u nich tendencja do posługiwania się ukrytymi teoriami osobowości studentek/studentów

Tabela 3. Współczynniki korelacji r-Pearsona charakteryzujące poziomy zależności pomiędzy wskaźnikami inteligencji społecznej

badanych nauczycieli akademickich a ich tendencjami do posługiwania się

ukrytymi teoriami osobowości studentek/studentów

\begin{tabular}{|r|c|c|c|}
\hline $\begin{array}{r}\text { Ukryte teorie } \\
\text { osobowości }\end{array}$ & NbPS & NmPS & NbPS - NmPS \\
\hline Inteligencja społeczna & $-0,22$ & $-0,03^{*}$ & $-0,02^{*}$ \\
\hline $\mathrm{TZ}$ & $-0,02^{*}$ & $-0,17$ & $-0,03^{*}$ \\
\hline $\mathrm{TH}$ &
\end{tabular}

Objaśnienia:

wskaźniki inteligencji społecznej:

$\mathrm{TZ}$ - Test Zachowania,

TH - Test Historyjek,

NbPS - najbardziej preferowana/-y studentka/student,

NmPS - najmniej preferowana/-y studentka/student,

poziom istotności: * $p<0,05 ; * * p<0,01 ; * * * p<0,001$.

Przedstawione w tabeli 3 dane wskazuja na występowanie istotnych statystycznie zależności pomiędzy wskaźnikami inteligencji społecznej badanych nauczycieli akademickich a ich tendencjami do posługiwania się 
ukrytymi teoriami na temat osobowości studentek/studentów. Zależności te pokazuja, że im wyższy wskaźnik inteligencji społecznej badanych nauczycieli szkoły wyższej, tym nieco mniejsza u nich tendencja do posługiwania się ukrytymi teoriami na temat osobowości studentek/studentów.

\section{Dyskusja wyników i zasadnicze wnioski}

Celem badań było ustalenie, czy istnieje związek pomiędzy poziomem inteligencji społecznej badanych nauczycieli akademickich a występowaniem u nich tendencji do posługiwania się teoriami osobowości studentek/studentów. Przeprowadzone badania oraz ich analiza ilościowa i jakościowa potwierdziły sformułowana powyżej hipotezę badawcza o istnieniu takiego zwiazku. Podsumowując analizy zebranych wyników badań, można sformułować następuje wnioski.

Po pierwsze, badani nauczyciele akademiccy prezentuja przeciętny poziom inteligencji społecznej. Przy tym wyższy poziom zmienna ta osiagnęła w przypadku jej pomiaru Testem Historyjki. Niższy zaś, kiedy jej pomiaru dokonano Testem Zachowania. Można więc sądzić, że badani nauczyciele wykazali się większymi umiejętnościami społecznymi, trafniejszym spostrzeganiem innych ludzi, kiedy rozwiazywali przykładowe sytuacje społeczne oparte na materiale percepcyjnym (historyjki obrazkowe). Nieco mniej kompetencji badani nauczyciele wykazuja w zakresie zdolności przyswajania sobie i rozumienia reguł społecznych (zarówno ogólnych norm moralnych, jak i bardziej szczegółowych zasad czy przepisów dotyczących zachowań w określonego typu sytuacjach czy związanych $\mathrm{z}$ pełnieniem określonych ról), zdolności planowania działań służących rozwiazywaniu konkretnych problemów społecznych (w tym m.in. adekwatnego wykorzystania posiadanej wiedzy o regułach, godzeniu reguł sprzecznych, znajdowania rozwiązan kompromisowych) oraz zdolności do realizowania tych planów (czyli rzeczywistego sterowania sytuacjami społecznymi) ${ }^{21}$.

Po drugie, badana grupa nauczycieli akademickich ma tendencję do posługiwania się ukrytymi teoriami osobowości studentek/studentów. Przy czym zebrane wyniki badań własnych pokazuja, że respondenci

${ }^{21}$ Ibidem. 
mają nieznacznie większe tendencje do idealizowania studentki/studenta najbardziej przez siebie preferowanej/-go niż „dołowania” najmniej preferowanej/-go studentki/studenta.

Po trzecie, wystapiły istotne statystycznie zależności pomiędzy wskaźnikami inteligencji społecznej badanych nauczycieli akademickich a ich tendencjami do posługiwania się ukrytymi teoriami na temat osobowości studentek/studentów. Przy tym zależności te wskazuja, że im wyższy wskaźnik inteligencji społecznej respondentów, tym mniejsza tendencja u tych osób do posługiwania się ukrytymi teoriami na temat osobowości studentek/studentów.

Reasumując powyższe analizy wyników badań własnych oraz ich opis i interpretację, można podkreślić, że przedstawiony powyżej związek pomiędzy poziomem inteligencji społecznej badanych nauczycieli akademickich a ich tendencjami do posługiwania się ukrytymi teoriami na temat osobowości studentek/studentów okazał się dla części zmiennych istotny statystycznie (część obliczonych wartości współczynników korelacji r-Pearsona dla tych zmiennych okazała się istotna statystycznie). Należy jednak zaznaczyć, że wpływ na związek między tymi zmiennymi mają również inne zmienne niezależne - uboczne, które w przypadku relacji nauczyciel-student odgrywają niemała rolę. Sa to np. osobowości nauczycieli akademickich, wpływ środowiska uczelnianego czy też poziom wypalenia zawodowego, których nie kontrolowano w trakcie tych badań $^{22}$. Do tej grupy zmiennych należą również: wiek badanych osób, ich staż pracy, stan cywilny, a także bycie matka jednego lub kilkoro dzieci lub brak własnych dzieci. Wpływ tych ostatnich zmiennych ubocznych został uwzględniony.

${ }^{22}$ A. Janowski, Uczeń $w$ teatrze życia szkolnego, WSiP, Warszawa 1995; A. Gurycka, Bład w wychowaniu, WSiP, Warszawa 1990. 
Słowa kluczowe: inteligencja spoleczna, ukryte teorie, nauczyciel, student

\title{
SOCIAL INTELLIGENCE OF UNIVERSITY TEACHERS AND THEIR SECRET THEORIES ON STUDENTS PERSONALITIES
}

\begin{abstract}
Summary
In the article, the author focused on problems of dependence between social intelligence of university teachers and secret theories on students personalities formulated by them. In relations a teacher-student, like in other interpersonal contacts, participants experience reciprocal similarities and differences in the range of their opinions, evaluations, attitudes and feelings. An essential factor that decides about relation between a teacher-student is, among others, level of social intelligence of a teacher. The intelligence enables him/her better knowledge of students as well as their more accurate and full evaluation. Taking that into consideration, an examination in one hundred-group of university teachers was conducted. It aimed to check the hypothesis that university teachers of higher social intelligence, notice their students better and their students' secret theories on students personalities are more accurate.
\end{abstract}

Keywords: social intelligence, secret theories, teacher, student 


\title{
Katarzyna Wojciechowska
}

Uniwersytet Kazimierza Wielkiego w Bydgoszczy

\section{Determinanty różnicujące poczucie sensu życia studentów}

\begin{abstract}
Aby człowiek mógł być zadowolony z życia, jednym z najistotniejszych warunków jest, aby byt przekonany, że ma ono jakiś sens, jakaś wartość. Władysław Tatarkiewicz
\end{abstract}

\section{Wprowadzenie}

Problem poszukiwania i uświadamiania sobie przez człowieka sensu jego życia zajmował ludzkość na przestrzeni dziejów i pojawiał się wśród różnych kultur i społeczeństw. Zastanawiają się nad tym filozofowie, psychologowie, socjologowie, pedagodzy i przedstawiciele innych nauk, literaci, artyści oraz tzw. zwykli ludzie. Sa też tacy, którzy o tym nie myślą, oraz tacy, którzy nie widzą sensu swojego życia.

Współczesna sytuacja kulturowa określająca sytuację młodego człowieka w otaczającym go świecie spowodowała kryzys sensu życia. Janusz Mariański poszukuje przyczyn niepewności i zwatpienia w jakość bytu wśród młodzieży. Upatruje ich w osłabieniu wiary religijnej, tradycji, wzorców kulturowych, braku zainteresowań wśród młodzieży, a także we wszechobecnym konsumpcjonizmie, wzroście dobrobytu i dynamicznym postępie cywilizacyjnym ${ }^{1}$. Ludzie we współczesnym świecie zagubili niejako sens własnej egzystencji bądź próbują szukać go w zgubnych, ulotnych wartościach, w hedonizmie materialistycznym. Zapatrzenie w dobrobyt jako cel życia staje się niezwykle powszechne, a zarazem niebezpieczne, bowiem człowiek zaczyna widzieć siebie jedynie w kontekście tych powierzchownych dóbr i wartości, co skutkować może nieustannym lękiem przed ich utrata, a co za tym idzie - utratą samego siebie.

1 J. Mariański, W poszukiwaniu sensu życia. Szkice socjologiczno-pastoralne, Wyd. KUL, Lublin 1990, s.135. 
Za problem współczesnego świata można uznać również sytuację, w której młodzi ludzie, zadajac sobie pytania o sens życia, sens ich istnienia, nie moga znaleźć na nie odpowiedzi bądź jest to dla nich niezwykle trudne. Rzadko kiedy podejmują w ogóle refleksje na ten temat, bo żyja tu i teraz, z dnia na dzień, nie zastanawiając się nad jutrem, nad swoja mniej lub bardziej odległa przyszłością. Jaki jest sens mojego życia? Jaki jest sens tego, co robię? Jakie mam pasje, wartości, dla których żyję? Dlaczego akurat nimi się kieruję? Jakie mam cele, plany? Co chcę osiagnąć w życiu? Te pytania, jeśli już stają się inspiracją do rozważań, prowadzą często do pesymistycznych rozmyślań. Młodzi ludzie mówią o braku sensu lub maja problem $z$ jego odnalezieniem. Wiąże się to zapewne $z$ negatywna wizja siebie i brakiem możliwości samorozwoju w otaczajacym ich świecie. Dla młodych ludzi przygnębiajacy zdaje się być fakt życia w ciągłym stresie, w pędzie o „bycie tym najlepszym”, w pogoni za pięknem i pieniądzem, gdzie przede wszystkim liczy się dobry wizerunek i umiejętność bogacenia się, a wreszcie przebiegłość i spryt życiowy jednostki. Brakuje jednak czasu na „cieszenie się życiem”, na wewnętrzne refleksje o sensie życia - zapominając przy tym, że sprawą nadrzędną jest właśnie jego odnajdywanie. Oprócz pustki egzystencjalnej występuje w młodych ludziach pewien rodzaj nerwic ujawniający się w niedoli duchowej. Możliwe, że taka pesymistyczna perspektywa myślenia o życiu uzależniona jest od relacji pieniądz-szczęście, gdzie brak dóbr materialnych oznacza brak szczęścia i umiejętności czerpania radości z innych źródeł.

Społeczeństwo zaś, które jest nastawione wyłącznie na produkcję i jej wzrost, stwarza warunki niesprzyjające rozwojowi człowieka i tworzenia się sensu. Wielu młodych ludzi nie wie, po co żyje, po co pracuje, jaki jest cel ich życia².

Nie można oczywiście wskazać nikomu sensu jego życia, można jednak ukazać mu „istnienie” tego sensu i przekonać go, że bez względu na okoliczności życie zawsze ma sens. Większość ludzi uważa swoje życie za przeciętne, zwyczajne i „szare”. Należy jednak pamiętać, że w każdym zwykłym, skromnym życiu mogą być realizowane cenne wartości i może być doskonalona własna osobowość, cała sztuka naszej egzystencji po-

2 Ibidem. 
lega bowiem na odnajdywaniu szczęścia w „szarej codzienności”. Dlatego należy na ten ważny problem zwrócić uwagę w pracy wychowawczej. Powinniśmy przez całe życie uczyć się dostrzegania tych cennych wartości i urzeczywistniania ich w codzienności.

Można więc śmiało powiedzieć, że koncentracja na sensie życia, a właściwie na świadomym jego odnajdowaniu, to odpowiedź na duchowe potrzeby współczesnego człowieka ${ }^{3}$.

\section{Uzgodnienie terminologiczne}

Aby wyjaśnić strukturę formalna pojęcia „sens życia”, warto odwołać się do rozważań aksjologicznych Tadeusza Czeżowskiego, przyjmuje on bowiem trzy znaczenia zwrotu „sens życia”. Pierwsze można nazwać sensem wewnętrznym, który wynika $z$ indywidualnych wyborów i ich konsekwencji narastajacych przez cały czas jego trwania. Drugi - sensem społecznym rozumianym jako wartości wytworów, jakie czyjeś życie po sobie pozostawia dla jakości zbiorowej egzystencji. Trzecie odnosi się do sensu filozoficznego, który związany jest ze spojrzeniem na świat jako całość, której częścia jest życie każdego człowieka. Te trzy znaczenia zaproponowane przez autora pozwalają uznać, że życie posiada sens, jeżeli jest ułożone rozumnie i celowo: nie każde życie musi mieć bowiem sens wewnętrzny lub społeczny, ale musi być właściwie ukształtowane. Sens filozoficzny jest rozumiany tak, że albo każde życie ludzkie ten sens posiada (jeżeli świat posiada sens jako całość, przy czym różne życia posiadaja różnorodne sensy), albo też żadne życie ludzkie nie posiadałoby sensu, jeżeliby wszystko w świecie miało być bezsensowna gra przypadku. Zarazem trzy powyższe znaczenia jak gdyby zazębiaja się, tzn. że czyjeś życie może posiadać zarówno sens wewnętrzny, społeczny, jak i filozoficzny. Być może nawet, że te trzy różne sensy składają się dopiero na jeden sens życia całkowity, będąc jak gdyby jego poszczególnymi stronami ${ }^{4}$.

Trafne wydaje się być także porównanie życia do zadania, które człowiek otrzymuje do rozwiązania - sens życia zaś pojmowany jest jako roz-

3 V.E. Frankl, Wola sensu. Założenia i zastosowanie logoterapii, tłum. A. Wolnicka, Czarna Owca, Warszawa 2010.

4 T. Czeżowski, Odczyty filozoficzne, PWN, Torun 1858. 
wiązanie, które trzeba znaleźć. Zadania przypadające różnym ludziom różnią się między sobą: jedno życie jest łatwe, inne trudniejsze, niektóre bardzo trudne. Określa je sytuacja życiowa po części narzucona jednostce $z$ zewnątrz i z góry, lecz również sam człowiek układa ją sobie w pewnym stopniu. Ten, kto znajdzie właściwe rozwiązanie, nada sens swojemu życiu. Życie zaś nie miałoby sensu w bezwzględnym znaczeniu tego wyrażenia, gdyby zadanie było zasadniczo nierozwiazywalne. Poglad na świat decyduje o tym, jak ktoś rozstrzyga zagadnienie sensu życia. Niniejsze rozważania pragna w tym dopomóc przez wskazanie, jakie dadzą się tu rozróżnić możliwości ${ }^{5}$.

Trzeba pamiętać o tym, że sens życia stale ulega przemianom, za to nigdy nie przestaje istnieć. Warto więc starać się o to, by poszukiwać go i świadomie odnajdywać. Mogą w tym pomóc założenia logoterapii Viktora Emila Frankla, gdzie sens życia można odkryć na trzy sposoby:

1. Poprzez twórcza pracę lub działanie.

2. Poprzez doświadczanie czegoś lub kontakt $z$ innym człowiekiem.

3. Poprzez to, jak znosimy cierpienie.

Pierwszy sposób dotyczy analizy zadań, dokonań i osiagnięć, jakie zdołał człowiek przedsięwziąc i jakie zdołał zrealizować. Drugim ze sposobów odnajdywania sensu w życiu jest doświadczenie czegoś - np. dobroci, prawdy i piękna - poprzez naoczny kontakt $z$ przyrodą lub kultura, a także nie mniej ważny bezpośredni kontakt $z$ innym człowiekiem, którego wyjatkowości możemy doświadczyć poprzez miłość. Trzeci sposób związany jest $z$ radzeniem sobie $z$ nieuniknionym cierpieniem. Frankl podkreśla, że jesteśmy gotowi cierpieć pod warunkiem, że nadamy swojemu cierpieniu jakieś znaczenie. Według autora cierpienie w pewnym sensie przestaje być cierpieniem w momencie, gdy nada mu się sens, choćby sens ofiary. Innymi słowy, sens życia według Frankla ma charakter bezwarunkowy, ponieważ obejmuje nawet potencjalny sens nieuchronnego cierpienia ${ }^{6}$.

Bezsprzecznie jednym $z$ najistotniejszych czynników warunkujących wolę życia bądź jej brak u młodych ludzi są wartości, a pierwsza i najogólniejszą wartościa jest życie oraz nadanie mu sensu. Uświadamiając sobie

\footnotetext{
5 Ibidem.

6 V.E. Frankl, Wola sensu...
} 
bowiem zależności między celami i wartościami determinującymi ludzkie życie, dochodzimy do sformułowania definicji życia sensownego:

Życie ma sens, jeżeli zostało tak ułożone, iż tworzy całość zmierzająca rozumnie ku zrealizowaniu celów najlepszych $z$ tych, do których zrealizowania w danych warunkach jesteśmy zdolni .

\section{Metoda i materiał badawczy}

$Z$ uwagi na ważne znaczenie podjętej problematyki sensu życia i jego poszukiwania jako istoty i celu ludzkiej egzystencji przeprowadzono badania wśród studentów I roku studiów pierwszego stopnia i II roku studiów stacjonarnych drugiego stopnia specjalności: doradztwo zawodowe i personalne, edukacja dla bezpieczeństwa i nauczanie historii, fizyka, promocja zdrowia i resocjalizacja, mające na celu poznanie poczucia sensu życia studentów oraz zależność jego odczuwania od takich czynników, jak: płeć, wiek i posiadanie partnera ${ }^{8}$. Procedurę badawcza oparto na metodzie sondażu diagnostycznego $z$ wykorzystaniem kwestionariusza ankiety. Na podstawie analizy literatury ustalono, że człowiek ma poczucie sensu życia, gdy:

- posiada wartości, dla których warto żyć,

- codzienne jego obowiązki sa źródłem zadowolenia i radości,

- wie, że osiagnie w życiu to, co chce,

- czuje się potrzebny innym,

- „dom” jest dla niego czymś bardzo ważnym,

- ma wiele zainteresowań, pasji,

- ciekawi go wiele spraw, które dzieja się dookoła niego,

- jest pewien swojej przyszłości, wiąże z nia pozytywne emocje,

- ma szansę robić to, na co ma ochotę,

- to, co robi (nauka, praca), ma dla niego duże znaczenie,

- przeważnie wie, co przyniesie następny dzień,

- rzadko czuje się przygnębiony,

7 M. Rorat, Wartości i poczucie sensu życia młodzieży z dysfunkcja narzadu ruchu, Wyd. UR, Rzeszów 2006, s. 37.

$8 \mathrm{~W}$ opracowaniu wykorzystano wyniki badań przeprowadzonych do pracy magisterskiej przez K. Rinc. 
- wyznacza sobie dalekie cele,

- liczą się dla niego interesy świata, w którym żyje,

- jest pełen chęci i konsekwentnie daży do określonego celu,

- uważa, że jego życie jest ciekawe,

- nie czuje się w życiu zagubiony,

- jest spokojny o to, że w przyszłości nie będzie samotny lub odrzucony.

W badaniach wzięło udział łącznie 100 osób. W młodszym wieku (1920 lat) 44 osoby, starsi studenci (24-25 lat) stanowili grupę 56-osobową. Ponad połowa (61\%) respondentów posiada partnera. Badani mieli poddać ocenie swój status materialny. $42 \%$ osób oceniło swój status materialny na średnio zadowalający, 38\% jest zadowolona ze swojego statusu i aż 20\% ogółu uważa swój status za niezadowalający. Najpopularniejszym sposobem wychowania w rodzinie okazał się styl demokratyczny (67\%), następnie autorytarny (24\%), a w skrajne wartości wpisało się $9 \%$ dla stylu liberalnego. W kwestii statusu rodzinnego $66 \%$ badanych pochodzi $z$ rodziny pełnej, $23 \% \mathrm{z}$ rozbitej, a $10 \%$ podało, że jeden $z$ rodziców nie żyje.

\section{Wyniki badań i dyskusja}

Odpowiadając na problem główny dotyczacy poczucia przez studentów sensu życia, można ogólnie stwierdzić, że badani studenci maja pozytywne nastawienie do życia. Wyjątek stanowi brak pewności co do swojej przyszłości. Tylko w tym pytaniu pojawiły się przeważające odpowiedzi negatywne. Jedynie $27 \%$ ogółu uważa, że wielu rzeczy można być w życiu całkowicie pewnym. Natomiast w pytaniu otwartym dotyczacym odczuć zwiąanych ze swoja przyszłościa przeważała niepewność (29\%) i obawa przed brakiem pracy (22\%). Może być to bezpośrednio zwiazane ze świadomościa trudnej sytuacji gospodarczo-politycznej w naszym kraju, wysokim stanem bezrobocia, brakiem dla młodych, wykształconych ludzi satysfakcjonującej pracy w zawodzie i perspektyw do samorozwoju. Może mieć to również związek $\mathrm{z}$ problemami w osiaganiu zamierzonych celów i towarzyszącymi temu różnymi obawami i lękami, aż 35\% respondentów przyznało się bowiem, że szybko traci zapał i chęci w konsekwentnym dążeniu do określonego celu. 
Dzięki wynikom przeprowadzonych badań można stwierdzić, że respondenci wiedza, co jest dla nich ważne i wartościowe (99\%). Bardzo ważne miejsce w życiu badanych zajmuje miłość(81\%), zaraz po niej rodzina (69\%), a następnie przyjaźń (58\%). Prawie połowa ankietowanych wskazała jako kolejne w hierarchii szczęście $(45,4 \%)$ i zdrowie $(44,4 \%)$. Należy zauważyć, że uznawane przez studentów wartości niosące sens życiu charakteryzuja się przede wszystkim odniesieniem do szczęścia osobistego i rodzinnego, niewielka grupa badanych (poniżej 9\% ogółu) podkreśla bowiem, że jest dla nich ważna wiara, uduchowienie, patriotyzm czy zobowiązania wobec ludzi. Potwierdza to zanik tradycyjnych wartości wszechobecny we współczesnym świecie. Jednocześnie prawie co czwarty badany podkreśla znaczenie pieniędzy i dostatniego życia, co tylko jest potwierdzeniem tej tezy.

Z badań wynika, że codzienne obowiąki są źródłem zadowolenia i radości dla większości studentów (74\%). Badane osoby wiedza, co chca osiagnać w życiu (91\%), oraz maja wiele konkretnych planów na przyszłość (88\%). Oba te zagadnienia dotyczą w głównej mierze satysfakcjonującej pracy, założenia rodziny oraz pomyślnego ukończenia studiów. Należy zauważyć, że te cele życiowe sa głównie związane $z$ teraźniejszością, czyli z celami krótkofalowymi, których realizacja daje zastrzyk energii i motywacji na pewien czas, ale nie czyni życia bogatszym i pełniejszym na drodze poszukiwania sensu.

Badane osoby czują się potrzebne innym (97\%), a swój „dom” traktuja personalnie i wyjatkowo (91\%). Zaspokojone zostaja w nim takie potrzeby, jak poczucie bezpieczeństwa (40\%) oraz akceptacja, miłość i wsparcie (23\%). Co trzeci badany nie jest zainteresowany tym, co dzieje się dookoła niego, natomiast większość respondentów (71\%) ma zainteresowania i pasje, w które się angażuje. Problem pojawił się jedynie $z$ identyfikacją pojęć „zainteresowanie”, „pasja”, gdyż głównie wśród młodych ankietowanych powtórzyły się takie wypowiedzi, jak: „spotkania z przyjaciółmi”, „rozmawianie”, „imprezy, clubbing, dziewczyny” oraz „spacery”. Pasja natomiast to jakieś silne zainteresowanie, zamiłowanie, a nie tylko forma spędzania wolnego czasu.

Poniżej zamieszczone zostały ogólne wnioski dotyczące problemów szczegółowych zawierających się w pytaniu: Jak poczucie sensu życia studentów różnicowane jest przez płeć, wiek i posiadanie partnera? 
Analizując wyniki badań pod kątem płci, można wyróżnić typowe dla stereotypów zróżnicowania i tendencje:

1. Kobiety cenia sobie bardziej od mężczyzn takie wartości, jak: rodzina, odpowiedzialność i zdrowie, natomiast mężczyźni stawiaja bardziej na: pieniądz, dostatnie życie, honor i zobowiązania wobec ludzi.

2. Kobiety wolą wykonywać prace domowe (odchylenie $8,1 \%)^{9}$, $\mathrm{w}$ tym sprzątanie i gotowanie, natomiast mężczyźni wolą zająć się pracą i zarabianiem pieniędzy na rodzinę.

3. Na pytanie: „Co chcesz osiagnąć w życiu?” kobiety postawiły na satysfakcjonująca pracę (odchylenie $8 \%$ ), rozwój w dziedzinie edukacji (odchylenie 11,6\%), swoich pasji i samorealizację (odchylenie 7\%), natomiast mężczyźni wiążą swoje główne cele $z$ godnym i dostatnim życiem (odchylenie 6,9\%).

4. Kobiety częściej myślą o założeniu własnej rodziny, ślubie, urodzeniu i wychowaniu dzieci (odchylenie 10\%), natomiast mężczyźni pragna bogactwa, sławy i wielu osiagnięć, szczególnie w sporcie (odchylenie 12,2\%).

5. Kobiety zainteresowane sa przede wszystkim życiem rodzinnym i towarzyskim (odchylenie 18,5\%), a mężczyźni życiem politycznym swojego miasta i kraju (odchylenie 23,7\%).

6. Kobiety częściej popadają w stan przygnębienia.

7. Kobiety boja się o to, że w przyszłości będa samotne lub odrzucone, w przeciwieństwie do mężczyzn, którzy postrzegaja przyszłość bardziej optymistycznie.

Wiek również okazal się zmienną różnicującą myślenie na temat sensu życia:

1. Studenci w wieku 19-20 lat czują się dużo bardziej zagubieni w życiu niż ich starsi koledzy (odchylenie 16\%).

2. Młodsi badani nie odnajdują sensu i ciekawości do świata, który ich otacza (odchylenie $7,3 \%$ ).

3. Prawie co czwarty ankietowany w wieku 19-20 lat uważa, że jego życie nie jest ciekawe (odchylenie $7 \%$ ).

9 Wszystkie rodzaje zależności obliczane sa na podstawie odchylenia od wartości średniej, przyjmując 5\% jako granicę istotności statystycznej za: J. Brzeziński, Elementy metodologii badań psychologicznych, PWN, Warszawa 1984. 
4. Ukończenie studiów jest dla starszych badanych bliższym i co się $z$ tym wiąże ważniejszym celem do zrealizowania niż dla osób młodszych (odchylenie 9,4\%).

5. Młodsi badani mniej cieszą się $z$ pracy jako codziennego obowiązku.

6. Młodsi ludzie maja znacznie mniej zainteresowań i pasji w życiu.

7. Starsi respondenci odczuwaja jedynie większą niepewność co do swojej przyszłości (odchylenie 11,7\%).

Generalnie posiadanie partnera wplywa pozytywnie na poczucie sensu życia, a potwierdzają to następujące zależności:

1. Powoduje wzrost znaczenia takich wartości, jak honor (odchylenie $8,6 \%$ ), godność (odchylenie $6,6 \%$ ), poczucie odpowiedzialności (odchylenie 6,9\%) i bezpieczeństwa.

2. Respondenci posiadający partnera znacznie częściej podaja, że ich źródłem zadowolenia i radości sa codzienne obowiazki związane $z$ rodzina (odchylenie od wartości średniej 16\%).

3. Osoby posiadajace partnera maja większe przekonanie o tym, co przyniesie następny dzień (odchylenie od wartości średniej 5,9\%).

4. Dzięki partnerowi rzadziej czujemy się przygnębieni (odchylenie $9,2 \%)$.

5. Widzimy sens w wyznaczaniu sobie dalekich celów (odchylenie $10,5 \%)$.

6. Wierzymy, że sytuacja $\mathrm{w}$ przyszłości nie będzie gorsza, niż jest teraz, a nawet będzie lepsza.

7. Nie czujemy się w życiu zagubieni, znamy swoje miejsce w świecie.

8. Jesteśmy spokojni i pewni o to, że w przyszłości nie będziemy samotni lub odrzuceni (odchylenie 11,1\%).

9. Z kolei osoby, które nie maja partnera, dużo bardziej skupiają się na możliwościach swojego rozwoju, pasji i samorealizacji (odchylenie 14,2\%). 


\section{Podsumowanie}

Zagadnienia sensu życia wydaja się być najważniejszymi, jakie człowiek może sobie postawić i do których rozwiązania może dążyć. Brak sensu życia oznacza bowiem zagubienie, problemy $z$ identyfikacja siebie i otoczeniem oraz znalezienie się $\mathrm{w}$ pustce egzystencjalnej. W sposób szczególny sensu życia poszukuja osoby młode, w okresie wczesnej dorosłości, przeżywające trudne doświadczenia życiowe, stojące przed ważnymi decyzjami oraz poszukujące odpowiedzi na pytania odnośnie do swojej tożsamości i określenia swojego miejsca w świecie. W dzisiejszych czasach liczy się pęd za pieniądzem, za popularnościa i sława, za „byciem na szczycie”, ciagły wyścig z czasem. Robimy wszystko aktywnie, lecz goraczkowo, a po latach nawet nie wiemy, czemu poświęciliśmy swoje życie. Czasami zatracamy się w tym materialistycznym wirze, gubimy cel i sens naszej podróży ludzkiego życia. Nie wiemy, dokąd i po co się tak śpieszymy, krążymy wokół. Budujemy coraz to piękniejsze i bogatsze domy, ale zapominamy, co jest najważniejsze, co tak naprawdę tworzy to wewnętrzne „bogactwo domu”.

Egzystencjalna pustka to zjawisko bardzo szybko się rozprzestrzeniające i nasilajace, a co najgorsze, stanowiące coraz powszechniejszy problem wśród młodych ludzi. Potwierdzaja to badania statystyczne Frankla przeprowadzone wśród studentów medycyny na Uniwersytecie Wiedeńskim:

40 procent pochodzacych $\mathrm{z}$ Austrii, RFN i Szwajcarii młodych ludzi z własnego doświadczenia znało pojęcie egzystencjalnej pustki, podczas gdy $\mathrm{w}$ grupie studentów amerykańskich odsetek ten wyniósł nie 40 , lecz 81 procent $^{10}$.

Nasuwa się zatem pytanie, w jaki sposób możemy sobie radzić $z$ odczuwaniem wewnętrznej pustki?

Pierwszym rozwiązaniem, jakie się nasuwa, może być przyjęcie zdrowej filozofii życia, dzięki której zdołamy wykazać, że życie każdego człowieka naprawdę ma sens. Założenie to opiera się na koncepcji wartości wynikających z zajęcia określonej postawy, pamiętając przy tym, że

${ }^{10}$ V.E. Frankl, Wola sensu..., s. 113. 
współczesny zanik tradycji wpływa jedynie na wartości uniwersalne, ale nie na niepowtarzalne sensy ${ }^{11}$.

Po drugie, ważna jest umiejętność rozróżnienia pustego życia od chwilowego przygnębienia, poczucia klęski czy sezonowej depresji. Czasem pozornie poczucie bezsensu jest wywołane smutnym nastrojem i rozczarowaniem do siebie samego lub wobec źle wykonanego bądź wcale niewykonanego zadania. Porażka traktowana jest wtedy jako tragedia, jako odebranie całej radości życia, aż w końcu jako bodziec do refleksji nad własnym życiem, które na tę chwilę utraciło sens. Trzeba jednak pamiętać, że smutny człowiek nie gubi sensu swojego życia, on go raczej szuka $^{12}$.

„Może życie nie ma sensu, ale i biadanie nad bezsensem życia również nie ma sensu. Amen" ${ }^{13}$.

Pytania o sens ludzkiego bytu nie zostały dotychczas bezsprzecznie rozstrzygnięte. Problemu sensu życia nie da się do końca wyjaśnić $\mathrm{w}$ świetle danych nauk empirycznych. Ostateczne odpowiedzi wkraczaja w sferę nieprzekraczalnej dla psychologa, socjologa i pedagoga tajemnicy życia i śmierci. Pytania te, jak i wiele innych pochodnych, pozostają więc nadal otwarte.

Słowa kluczowe: sens życia, poczucie sensu życia, wiek, płeć, posiadanie partnera a poczucie sensu życia

\title{
DETERMINANTS DIFFERENTIATING STUDENTS' SENSE OF PURPOSE IN LIFE
}

\begin{abstract}
Summary
The article analyzes issues regarding Department of Pedagogy and Psychology students' sense of purpose in life. It was established that it is the most essential problem a human being is faced with and to which a solution should be

\footnotetext{
${ }^{11}$ Ibidem.

12 J. Hołówka, Problemy etyczne w literaturze pięknej, WSiP, Warszawa 1994.

13 T. Konwicki, Zorze wieczorne, ALFA, Warszawa 1991.
} 
sought. The empirical material concerning students' approaches to life's meaning was collected during the studies. The results were interpreted depending on such factors as: sex, age and having a partner. All variables showed some significant differentiation and certain tendencies. Overall, the surveyed students have a positive attitude to life, except for uncertainty of their future. Generally, the respondents know what is important and valuable to them and what they want to achieve in life. However, every third respondent is not interested in the surrounding environment and the young students are not able to identify their interests and passions.

Keywords: meaning of life, a sense of purpose in life, age, sex, having a partner and a sense of purpose in life 


\section{Hubert Kupiec}

Uniwersytet Szczeciński

\section{Dialogiczność w kształceniu pedagogicznym studentów resocjalizacji}

\section{Wprowadzenie}

Od dłuższego już czasu toczy się dyskurs społeczny ${ }^{1}$ oraz nauko$w^{2}$, który uzmysławia nam jeżeli nie sytuację kryzysową, to $z$ pewnością wiele nieprawidłowości i mankamentów, które dotyczą funkcjonowania uczelni wyższych i kształcenia akademickiego. Nie wchodząc jednak w polemikę na temat tego, w jakim stopniu status quo uczelni wyznaczaja reguły gospodarki wolnorynkowej, a w jakim idea niezależności w poszukiwaniu prawdy przez uprawianie wolnej od wszelkich ograniczeń nauki $^{3}$, chciałbym w swoim artykule podzielić się refleksją wynikająca $z$ doświadczeń kształcenia pedagogicznego studentów opierającego się na rozwijaniu w nich zdolności do tworzenia dialogicznej relacji. Moim celem jest ukazanie, w jakim stopniu przyjęte formy pracy w kierowanym przeze mnie Kole Naukowym Resocjalizacji przyczyniły się do rozwoju tych komponentów roli zawodowej wychowawcy, które warunkuja rozwijanie się postawy dialogicznej u biorących w nim udział studentów. Stąd też $\mathrm{w}$ dalszej części przedstawione zostanie znaczenie dialogu w kształceniu i wychowaniu, autorska propozycja cech i kompetencji warunkujących

1 Jako przykład może tutaj służyć cykl artykułów publikowanych przez „Gazetę Wyborcza”" oraz towarzyszaca im dyskusja w mediach (w tym na forach internetowych).

2 M. Czerepaniak-Walczak, Fabryka dyplomów czy universitas? O „nadwiślańskiej” wersji przemian edukacji akademickie, Impuls, Kraków 2013.

3 M. Czerepaniak-Walczak, Homo academicus $w$ świecie homo oeconomicus. $O o b-$ szarach i przejawach zmagań $z$ akademickim zniewoleniem, „Pedagogika Szkoły Wyższej" 2014, nr 1. 
zdolność do bycia wychowawca dialogizującym oraz efektywność dialogicznych form pracy $z$ młodzieża akademicka zastosowanych we własnej pracy dydaktyczno-wychowawczej w ramach prowadzonego Koła Naukowego Resocjalizacji.

\section{Tworzenie relacji dialogicznej jako forma kształcenia pedagogicznego}

Dialog kojarzony jest zazwyczaj z rozmowa, w której pomiędzy co najmniej dwiema stronami następuje wymiana informacji o postrzeganych przez nie aspektach analizowanej dziedziny rzeczywistości. W trakcie tej rozmowy obie strony odnoszą się na zmianę do wypowiedzi interlokutora. Jest też stawianiem pytań zapraszających do poszukiwania odpowiedzi, słuchaniem pytań i udzielanych przez druga stronę odpowiedzi oraz udzielaniem odpowiedzi na zadawane przez nia pytania. Tak rozumiany dialog sprowadzany jest najczęściej do metody, która jest rodzajem paratechnicznego działania ułatwiającego osiaganie zaplanowanych celów edukacyjnych. Jest to

forma wymiany myśli pomiędzy nauczycielem a uczniem, [która przyp. H.K.] sprzyja aktywnemu uczestnictwu wychowanka w procesie kształcenia i wychowania, przyczyniając się, przynajmniej w założeniu, do uzyskiwania lepszych jego wyników ${ }^{4}$.

Tym, co zbliża tę metodę do dialogu wychowawczego, jest sytuacja, w której żadna ze stron nie zna jeszcze odpowiedzi na stawiane nawzajem pytania i dopiero poprzez prowadzenie rozmowy lub dyskusji wspólnie poszukiwana i formułowana jest odpowiedź. Takie podejście opiera się bowiem na uznaniu równorzędnej pozycji w dążeniu do prawdy bez względu na zasób posiadanej wiedzy i umiejętności, co nadaje relacji uczeń-nauczyciel bardziej partnerski charakter.

Pojęcie dialogu może mieć jednak jeszcze inne, szersze znaczenie. Utożsamia się go wówczas ze spotkaniem Ja $z$ Ty, które stanowi wydarzenie konstytuujące relację etyczna pomiędzy nimi. Rozmowa jest tu tylko środkiem i nie musi ograniczać się do słów lub gestów, bo

4 J. Rutkowiak, O dialogu edukacyjnym. Rusztowanie kategorialne, w: idem, Pytanie, dialog, wychowanie, PWN, Warszawa 1992, s. 14. 
dialog dochodzi do skutku poza treścia komunikowania i jest najbardziej osobowym wyrazem kontaktu $z$ innymi. Dialog nie ogranicza się do czynności informowania, gdyż [...] zawsze towarzyszą mu uczucia, których nie sposób wyrazić w słowach ${ }^{5}$,

a ich znaczenie we wzajemnym oddziaływaniu na siebie jest ogromne. Chodzi więc o pewien sposób bycia wobec i z druga osobą, który wyraża się w akceptacji jej odrębności, inności oraz w gotowości do odkrywania dobra, w tym, co wydarza się pomiędzy nimi podczas tego spotkania. Zadania, które pojawiają się wraz z wyjściem na spotkanie drugiej osoby, odnosza się do tego, jak możemy pomóc sobie nawzajem w zrozumieniu tego, kim jesteśmy, a kim powinniśmy być, i co w związku z tym możemy zrobić, aby stawać się lepszymi dla siebie i siebie nawzajem. W kontekście celu, jakim jest kształcenie pedagogiczne studentów, pytania te odnosza się do poszukiwania w interakcjach $z$ innymi uczestnikami tego procesu odpowiedzi na pytanie, kim jest i jaki jest dobry wychowawca oraz w jaki sposób możemy pomagać sobie nawzajem, aby zbliżać się do tego ideału.

A zatem dialog może być traktowany zarówno jako metoda dydaktyczna, jak i wychowawcza. W tym drugim, szerszym znaczeniu,

aby osiagnać pełnię dialogu, najpierw należy nawiązać kontakt z uczniem poprzez komunikację, następnie ubogacić ją relacjami interpersonalnymi, w których szczególną rolę pełnią zasady miłości i podmiotowości, i dopiero na tym fundamencie można przejść do budowania i realizowania dialogu edukacyjnego ${ }^{6}$.

Cytowany autor zwraca uwagę, że warunkiem efektywności stosowania form i metod dialogu dydaktycznego ${ }^{7}$ jest uprzednie nawiazanie dialogicznej relacji $z$ wychowankiem (uczniem, studentem), która polega na budowaniu więzi i zaufania przez okazywanie mu szacunku, zainteresowania jego sytuacja oraz potrzebami, wspieraniu go w wytyczaniu i realizacji celów życiowych, gdy jest to wyrazem troski o jego pomyślny rozwój.

5 D. Kreft, Dialog podstawa więzi międzyludzkiej $w$ filozofii Bubera i Bartha, w: Dialog. Idea i doświadczenie, red. S. Kruszyńska, K. Bembennek, I. Krupecka, Wyd. UG, Gdańsk 2011, s. 60-61.

6 M. Śniė̇yński, Sztuka dialogu, teoretyczne założenia a szkolna i akademicka rzeczywistość, Wyd. Akademii Pedagogicznej, Kraków 2008, s. 19.

7 M. Śnieżyński, Zarys dydaktyki dialogu, Wyd. PAT, Kraków 1998, s. 103-117. 
$Z$ tak rozumianej dialogiczności $z$ łatwością można by wymienić wiele korzyści płynacych dla obu uczestniczących w nim podmiotów. Ograniczając się jednak do najważniejszej, warto podkreślić tutaj jego osobotwórczą funkcję, która wiąże się z kształtowaniem i rozwijaniem postulowanych wyżej pożądanych cech osobowości i kompetencji, jakże istotnych dla odpowiedniej formacji przyszłych wychowawców.

\section{Wychowawca dialogujący w resocjalizacji - osoba moralna, refleksyjna, dojrzała emocjonalnie i kompetentna}

Jednym $z$ głównych celów kształcenia akademickiego studentów na uczelni pedagogicznej jest jak najlepsze przygotowanie ich do pracy zawodowej w charakterze wychowawcy. Dlatego u podstaw organizowania tego procesu nieustannie powinna się znajdować refleksja nad tym, jaki powinien być wychowawca. Źródłem tej refleksji jest zawsze pewna wizja (koncepcja) czy jeszcze ogólniej rzecz ujmujacc - sposób rozumienia tego, czym jest wychowanie, co stanowi jego istotę i jakie to implikuje cele. W zależności bowiem od tego, jak odpowiemy sobie na te podstawowe pytania, będziemy od osób, które zajmują się tym w praktyce, oczekiwali określonych postaw, cech osobowości i kompetencji, które decyduja o jakości realizowanej wizji (koncepcji) wychowania. Warto również pamiętać, że tworzywem do myślenia o wychowaniu i wychowawcy jest zazwyczaj albo analiza doświadczeń praktycznych, albo studium wiedzy teoretycznej (naukowej), albo pochodna $z$ prób łączenia jednego $z$ drugim.

Przyjmując zatem (arbitralnie ze względu na pluralistyczny charakter świata i teorii pedagogicznych), że wychowanie jest procesem budowania relacji dialogicznej przez współdziałanie dwóch równorzędnych podmiotów - wychowawcy i wychowanka, warto podkreślić, że mieści się ono w kategorii jedności działania i doznawania. Jak słusznie bowiem zauważa B. Śliwerski, „może być samym tylko działaniem kogoś, może być tylko przedmiotem czy efektem czyichś oddziaływań, ale może też być czymś, co zachodzi w przestrzeni międzyosobowej"». Istotą wychowania

8 B. Śliwerski, Wychowanie. Pojęcie-znaczenia-dylematy, w: Wychowanie. Pojęcia, procesy, konteksty - ujęcie interdyscyplinarne, t. I, red. M. Dudzikowa, M. Czerepaniak -Walczak, GWP, Gdańsk 2007, s. 36. 
jest interakcja pomiędzy dwoma podmiotami, które różnią się poziomem dojrzałości psychospołecznej, zasobami wiedzy, doświadczeń i kompetencji. Występujące pomiędzy nimi dysproporcje, o ile zachodzi współdziałanie, stanowia czynnik stymulujący oraz zapewniający wsparcie $\mathrm{w}$ procesie wielowymiarowego rozwoju osobistego, którego zwieńczeniem jest umiejętność odpowiedzialnego kierowania własnym rozwojem przez wychowanka. Wskaźnikiem jego dojrzałości jest również umiejętność tworzenia trwałych relacji dialogicznych $z$ innymi. Aby osiagnać ten cel, $z$ jednej strony potrzebna jest zatem dojrzała społecznie i emocjonalnie oraz kompetentna osoba dorosła, $z$ drugiej - gotowość oraz przyzwolenie dziecka na współdziałanie $z$ nim, która w dużej mierze zależy właśnie od cech osobowych i zdolności posiadanych przez wychowawcę.

Dojrzałość moralna i psychospołeczna wychowawcy oraz jego zasoby wiedzy i kompetencji nabierają szczególnego znaczenia w wychowaniu resocjalizujacym. Jest to bowiem praca $z$ osobami niedostosowanymi społecznie, które na skutek niekorzystnych warunków socjalizacji wykazuja szereg deficytów rozwojowych i zaburzeń utrudniajacych im efektywne pełnienie ról społecznych. Znajdując się najczęściej w dramatycznej sytuacji życiowej, krzywdza siebie i innych, nie poczuwajac się przy tym do odpowiedzialności za przekraczane normy społeczne, popełniane wykroczenia i przestępstwa. Dlatego warto jeszcze raz podkreślić, że „gwarantem prawidłowego przebiegu procesu resocjalizacji pojmowanej jako szansa i proces społecznego zdrowienia jest zawsze osoba wychowawcy". W związku $z$ tym w literaturze przedmiotu znajduje się wiele propozycji cech i umiejętności, które powinien posiadać dobrze przygotowany do tej pracy wychowawca.

I tak, Lesław Pytka ${ }^{10}$ zwraca wage na znaczenie tzw. wiary pedagogicznej w sens resocjalizacji, tj. w możliwość transformacji (poprawy) człowieka $z$ problemami w przystosowaniu się do oczekiwań społecznych. Niedostatek lub brak należytej troski wychowawców o jej podtrzymywanie na odpowiednim poziomie może bowiem prowadzić do wypalenia zawodowego, które znaczaco obniża efektywność ich pracy.

\footnotetext{
9 L. Pytka, Pedagogika resocjalizacyjna, Wyd. APS, Warszawa 2000, s. 192.

${ }^{10}$ Ibidem, s. 191-192.
} 
Według Henryka Machela ${ }^{11}$ do najważniejszych zalet wychowawcy resocjalizującego należy umiejętność dobrej komunikacji, której wskaźnikiem jest to, w jakim stopniu obie strony czują się zrozumiane i potrafią osiagnąc konsensus. Bardzo istotna jest także empatia, która polega na współodczuwaniu emocji i werbalizowaniu ich w kontaktach $z$ wychowankami. Ułatwia ona poznanie wychowanka i ma znaczenie terapeutyczne, gdyż przyczynia się do bezpiecznego (akceptowanego) uzewnętrzniania przeżywanych stanów emocjonalnych, co stanowi formę ich odreagowania. Ma ona również istotne znaczenie w budowaniu więzi i zaufania w relacjach $z$ wychowankiem, gdyż czuje się dzięki okazywanemu mu w ten sposób zrozumienia zauważony, wysłuchany i bezpieczny. Trzeba jednak od razu zastrzec, że zbyt duży poziom empatii niesie ze sobą ryzyko utraty pewnego dystansu emocjonalnego, który warunkuje obiektywizm oceny faktów i racjonalizm w podejmowaniu decyzji wychowawczych. Może być to nawet czynnikiem zwiększającym pojawienie się wypalenia zawodowego. Ewa Grudziewska i Agnieszka Lewicka ${ }^{12}$ zwracaja ponadto uwagę, że nadmierne empatyzowanie pozbawione racjonalnej oceny sytuacji naraża wychowawcę na niebezpieczeństwo manipulacji ze strony wychowanków. Dlatego wychowawca powinien być elastyczny i na tyle refleksyjny, aby w swoim postępowaniu obok współodczuwania umiał także okazywać asertywność oraz odporność na manipulację ze strony podopiecznych.

$Z$ kolei Robert Opora uważa, że wśród

niezbędnych umiejętności i cech osobowości niezbędnych do stworzenia twórczej relacji wychowawczej można wymienić: prawidłowe interpretowanie faktów; aktywne słuchanie i rozumienie tego, co mówi podopieczny; okazywanie empatii; bycie osoba kompetentna, godna zaufania, postępująca etycznie i jednocześnie autentyczna ${ }^{13}$.

${ }^{11} \mathrm{H}$. Machel, Rola i zadania kadry resocjalizacyjnej, w: Resocjalizacja, t. II, red. B. Urban, J.M. Stanik, PWN, Warszawa 2008, s. 222-228.

${ }^{12}$ E. Grudziewska, A. Lewicka, Empatyczny czy asertywny przedstawiciel personelu resocjalizacyjnego?, w: Resocjalizacja - od tradycji do wspótczesności. Wybrane konteksty, red. R.M. Ilnicka, J. Cichla, Akademia Humanistyczno-Ekonomiczna w Łodzi, Głogów 2010.

${ }^{13}$ R. Opora, Resocjalizacja. Wychowanie i psychokorekcja nieletnich niedostosowanych społecznie, Impuls, Kraków 2010, s. 63-72. 
Natomiast zdaniem Anetty Jaworskiej

za najbardziej pożądane osobowościowo cechy wychowawców resocjalizacyjnych należy uznać: psychiczna (a także fizyczna) sprawność umożliwiająca kreatywne i konsekwentne realizowanie zadań; posiadanie wiedzy psychologicznej i pedagogicznej umożliwiającej skuteczność działania praktycznego; biofilną i humanistyczna postawę do życia i innych ludzi; umiejętność okazywania życzliwości i przejawiany $\mathrm{w}$ tym zakresie autentyzm oraz niezbędna w humanistycznym nurcie wychowania resocjalizacyjnego cechę, którą najogólniej można nazwać „sympatia do ludzi”. Wychowawcę powinny charakteryzować także: zdolność do okazywania uczuć i emocji, wykazywanie zainteresowania ludźmi, okazywanie zrozumienia i dawanie wsparcia, co ma znaczenie zwłaszcza w pracy $z$ nieletnimi ${ }^{14}$.

Okazywanie życzliwości, zainteresowania i wsparcia warunkuje budowanie opartego na więzi emocjonalnej, wzajemnego zaufania zwłaszcza $\mathrm{w}$ pierwszym etapie resocjalizacji, na co wskazuje struktura tego procesu według Pytki ${ }^{15}$.

Przedstawiane przez poszczególnych autorów propozycje nie stanowią ani wyczerpującego kompendium pożądanych cech i umiejętności wychowawcy resocjalizujacego, ani tym bardziej pewnej spójności wynikającej $z$ przyjętego na gruncie określonej filozofii ideału wychowania. Dlatego chciałby zaproponować własna koncepcję cech i kompetencji wychowawcy resocjalizującego, która wiąże się ściśle $z$ jego zdolnościa i umiejętnościa nawiązywania dialogicznej relacji z wychowankiem, zgodnie $z$ przyjęta przeze mnie definicja wychowania wyrastająca $z$ założeń filozofii dialogu. Wychowanie w dialogu do dialogu zmierza ku odkrywaniu i doświadczaniu dobra w etycznym wymiarze spotkania wychowawcy $z$ wychowankiem ${ }^{16}$. Do tego, aby „wydarzało się” owe dobro, wychowawca powinien odznaczać się wysokim poziomem sprawności moralnych,

\footnotetext{
${ }^{14}$ A. Jaworska, Leksykon resocjalizacji, Impuls, Kraków 2012, s. 92.

${ }^{15}$ L. Pytka, Pedagogika resocjalizacyjna, s. 118.

${ }^{16}$ Więcej o implementacji założeń filozofii dialogu na grunt pedagogiczny można znaleźć w opracowaniu J. Gara, Pedagogiczne implikacje filozofii dialogu, Wyd. WAM, Kra-
} ków 2008. 
dojrzałością psychospołeczna, zdolnością do krytycznego, refleksyjnego myślenia oraz jak największymi zasobami kompetencji technicznych ${ }^{17}$.

Na znaczenie kondycji moralnej w pracy wychowawczej zwraca uwagę m.in. Iwona Jazukiewicz w swojej rozprawie dotyczącej cnót moralnych nauczyciela, cnota jest bowiem „sprawnościa osoby, ujawniana przez jej świadome i dobrowolne skierowanie się ku spełnianiu aktów moralnie dobrych"18. A zatem posiadanie jak największej liczby cnót (sprawności moralnych) przez wychowawcę zwiększa gwarancję, że będzie on współdzialał $z$ wychowankiem $z$ korzyścią dla jego rozwoju. Natomiast ich deficyt czy też niedorozwój zwiększa ryzyko traktowania go przez wychowawcę w sposób przedmiotowy i instrumentalny. W resocjalizacji dojrzałość moralna wychowawcy ma szczególne znaczenie ze względu na zróżnicowany stopień demoralizacji wychowanków, która jest wynikiem niekorzystnych warunków dotychczasowej socjalizacji. Trzeba bowiem pamiętać, że ich moralna poprawa w dużej mierze zależy od poziomu moralności wychowawców, którzy nie tylko maja być dla nich punktem odniesienia jako osoby znaczace, ale przez sposób traktowania ich uzmysławiać im wartość poszczególnych cnót moralnych.

Zdolności do krytycznego refleksyjnego myślenia to zdaniem Marii Czerepaniak-Walczak kluczowa kompetencja profesjonalnego nauczyciela-wychowawcy. Wyrażaja się one w umiejętności refleksyjnego i krytycznego osądu, który jest podstawą organizowania warunków umożliwiających wychowankom rozumienie i świadome wywoływanie zmian w przeżywanych sytuacjach edukacyjnych. Zakres tej kompetencji decyduje o umiejętności właściwego zachowania się w określonej sytuacji edukacyjnej, czyli najczęściej o stopniu adekwatności przejawianej reakcji (podjęciu bądź zaniechaniu działania), za której rezultaty jest on zdolny

\footnotetext{
17 Terminu tego używam za R. Kwaśnica, według którego kompetencje techniczne sprowadzają się do znajomości optymalnych sposobów ustanawiania i osiagania celów w pracy pedagogicznej. Pozwalają one na efektywną z prakseologicznego punktu widzenia operacjonalizację celów, dobór metod oraz organizację odpowiednich warunków umożliwiających realizację zamierzonych zadań. Zob. R. Kwaśnica, Wprowadzenie do myślenia o nauczycielu, w: Pedagogika - podręcznik akademicki, t. II, red. Z. Kwieciński, B. Śliwerski, PWN, Warszawa 2003.
}

${ }^{18}$ I. Jazukiewicz, Pedeutologiczna teoria cnoty, Wyd. US, Szczecin 2012, s. 166. 
wziąc pełną odpowiedzialność ${ }^{19}$. Umiejętność ta ważna jest również w budowaniu dialogicznej relacji $z$ resocjalizowanym wychowankiem. Jest ona potrzebna do demaskacji zachowań manipulacyjnych, które stanowia przeszkodę w osiaganiu autentyczności - podstawowego warunku dialogicznej relacji. Dzięki rozwiniętej refleksyjności wychowawca uwzględnia także więcej aspektów, które moga mieć istotne znaczenie w procesie budowania dialogicznej relacji $z$ wychowankiem. A poza tym krytyczny namysł na własnym działaniem pozwala mu na modyfikację własnego postępowania, co znacząco wpływa na jakość i efektywność podejmowanych przez niego oddziaływań resocjalizacyjnych.

Inteligencja emocjonalna jest najczęściej definiowana jako zbiór zdolności poznawczych warunkujacych efektywne przetwarzanie informacji emocjonalnych do wykorzystywania ich w celach adaptacyjnych. Przy czym, jak słusznie akcentują niektórzy badacze, należy zdawać sobie sprawę $z$ różnicy pomiędzy zdolnością a umiejętnościa (kompetencja), która odnosi się do określonego, behawioralnego działania. Zdolność jest czynnikiem warunkującym sprawność przebiegu pojedynczych operacji intelektualnych, a kompetencja warunkuje skuteczne funkcjonowanie w określonej sytuacji i jest praktyczna realizacją wielu różnych zdolności ${ }^{20}$. Zalicza się do nich: zdolność dostrzegania własnych emocji i doceniania ich znaczenia w funkcjonowaniu, zdolność do dostrzegania emocji innych ludzi, zdolność do ekspresji emocji, do ich rozumienia, do wykorzystywania emocji w myśleniu i działaniu, a także zdolność do regulowania własnych stanów emocjonalnych oraz wpływania na stan emocjonalny innych ludzi ${ }^{21}$.

Jak pokazuja badania Katarzyny Martowskiej ${ }^{22}$, inteligencja emocjonalna sprzyja nabywaniu i doskonaleniu kompetencji społecznych, do

${ }^{19}$ M. Czerepaniak-Walczak, Aspekty i źródła profesjonalnej refleksji nauczyciela, Edytor, Toruń 1997, s. 6-9.

${ }^{20}$ A. Matczak, K.A. Knopp, Znaczenie inteligencji emocjonalnej $w$ funkcjonowaniu człowieka, Stowarzyszenie Liberi Libri, Warszawa 2013, s. 16.

${ }^{21}$ Ibidem, s. 22-25.

${ }^{22}$ K. Martowska, Psychologiczne uwarunkowania kompetencji społecznych, Stowarzyszenie Liberi Libri, Warszawa 2012. 
których zgodnie $\mathrm{z}$ koncepcja Anny Matczak ${ }^{23}$ autorka zalicza asertywność, umiejętność nawiązywania intymnych relacji dzięki rozwiniętej komunikacji oraz umiejętność efektywnego działania w sytuacji ekspozycji społecznej. W pracy resocjalizacyjnej wymienione zdolności i kompetencje psychospołeczne decyduja o tworzeniu się więzi, bliskości oraz zaufania w relacjach pomiędzy wychowankiem a wychowawca i należą do podstawowych wyznaczników relacji dialogicznej. Odgrywają one również istotną rolę w okazywaniu sobie nawzajem szacunku, który jest podstawą podmiotowego traktowania się przez obydwie strony dialogicznej relacji.

\section{Dialogiczne formy kształcenia studentów w ramach działalności koła naukowego}

Wychodząc naprzeciw oczekiwaniom studentów oraz własnej krytycznej refleksji nad formą i treścia prowadzanych zajęć dydaktycznych, postanowiłem w ramach działalności prowadzonego przeze mnie Koła Naukowego Resocjalizacji zorganizować wspólnie ze studentami zajęcia szkoleniowe oparte na ideach dialogiczności. W tym celu zawarta została między nami umowa określająca zasady demokratycznego, dobrowolnego i systematycznego uczestnictwa we wspólnie zaplanowanych i realizowanych formach samokształcenia, których celem miało być podnoszenie wiedzy i kompetencji pedagogicznych.

Realizacja przyjętych założeń wymagała od każdego z 12 uczestników zobowiązania do cotygodniowej aktywności na trwających od 5 do 8 godzin spotkaniach odbywajacych się przez cały rok akademicki. Cały cykl szkoleń podzielony został na część przygotowawczą (5 miesięcy) realizowana na uczelni oraz część praktyczna ( 5 miesięcy w II semestrze) realizowana w placówkach resocjalizacyjnych $z$ udziałem młodzieży niedostosowanej społecznie. Łacznie studenci odbyli w ten sposób ponad 200 godzin szkolenia prowadzonego pod moim kierunkiem.

Struktura spotkań w fazie przygotowawczej obejmowała następujące formy opierające się na uczeniu się przez tworzenie relacji dialogicznej:

${ }^{23}$ A. Matczak, Kwestionariusz Kompetencji Społecznych (KKS). Podręcznik, Pracownia Testów Psychologicznych PTP, Warszawa 2001, s. 6-10, 24-25, za: A. Tomorowicz, Struktura kompetencji społecznych $w$ ujęciu interakcyjnym, „Psychiatria” 2011, t. VIII, nr 3, s. 92 . 
1. Przywitanie, podczas którego każdy mógł po kolei opowiedzieć, jak się aktualnie czuje i co wydarzyło się u niego ostatnio w życiu (tzw. barometr nastroju). W trakcie tej rundy każdy mógł również wyrazić swoją akceptację dla emocji przeżywanych przez innych lub udzielić komuś słów wsparcia, porady lub podziwu. W ten sposób studenci mieli okazję do doświadczania na sobie, jaką rolę odgrywa inteligencja emocjonalna w relacjach interpersonalnych, w tym także wychowawczych. Tym bardziej że w fazie szkoleniowej uzasadniony został cel wprowadzenia tej formy pracy przez dyskusję nad rola sfery emocjonalnej w funkcjonowaniu człowieka na podstawie wybranych tekstów z literatury naukowej.

2. Po takiej rundzie następowała realizacja zadania ustalonego na poprzednim spotkaniu, która w zależności od jego charakteru wymagała od studentów albo pracy indywidualnej, pracy w parach lub pracy grupowej. Obowiazywała zasada wcześniejszego przygotowania teoretycznej wiedzy na temat jakiegoś zagadnienia, która podczas spotkania staraliśmy się przełożyć na praktyczne działanie wychowawcze. I tak np. realizacja zajęć na temat komunikacji interpersonalnej wymagała od studentów najpierw wyszukania informacji przydatnych w prowadzeniu rozmów $z$ wychowankami niedostosowanymi społecznie, a następnie zastosowania ich podczas odgrywania typowych dla pracy resocjalizacyjnej sytuacjach. Po zakończeniu każdej scenki osoba odgrywajaca rolę wychowawcy otrzymywała informacje zwrotne na temat tego, co i dlaczego zrobiła dobrze, oraz tego, co, jak i dlaczego może zrobić inaczej, żeby była jeszcze bardziej skuteczna w swoim działaniu. $\mathrm{W}$ trakcie omawiania odgrywanych rozmów żywo dyskutowane były różne realnie istniejące i hipotetyczne aspekty zachowania się wychowawcy i wychowanka w danej sytuacji. Następowało dzielenie się zdobyta uprzednio wiedza teoretyczna oraz własnymi spostrzeżeniami i przemyśleniami, co mocno inspirowało uczestników do krytycznego, refleksyjnego myślenia nad własnym zachowaniem i głoszonymi pogląami. Była to zatem znakomita okazja do uczenia się od siebie nawzajem, na wła- 
snych błędach w duchu tolerancji i poszanowania dla odmienności poglądów każdego $z$ uczestników.

Dosyć obszerna tematyka kolejnych zadań wynikała $z$ poszukiwania odpowiedzi na pytanie, jak być dobrym, madrym oraz kompetentnym wychowawca zdolnym do tworzenia dialogicznej relacji $z$ wychowankiem, i w zwiazku $z$ tym obejmowała m.in. takie zagadnienia, jak: asertywność i empatia w pracy wychowawczej, sztuka motywowania wychowanka do zmiany (dialog motywacyjny), znaczenie aktywności twórczej w resocjalizacji (dialog w sztuce), terapeutyczne aspekty dialogu poprzez działalność artystyczna (arteterapia), specyfika i formy pracy grupowej i indywidualnej w resocjalizacji (dialog indywidualny i dialog $z$ grupa).

3. Po zrealizowaniu części zadaniowej, która zajmowała najwięcej czasu, bo ok. 3 godzin, następowało wspólne przygotowywanie posiłku $z$ przyniesionych przez uczestników wiktuałów, które miało również swój wymiar symboliczny - zbliżający ludzi do siebie. W trakcie spożywania kolacji odbywała się tzw. społeczność prowadzona za każdym razem przez kolejna osobę, na której każdy mógł podzielić się swoimi doświadczeniami i przemyśleniami zwiąanymi $z$ realizowanym w danym dniu zadaniem. Do refleksji oraz budowania relacji dialogicznej $z$ innymi zachęcały kolejne rundy $z$ pytaniami o to, czy ktoś chce komuś za coś podziękować na tych zajęciach, czego się dzisiaj dowiedział lub nauczył o sobie, o innych, co było dla niego trudne, nieprzyjemne i jak starał się sobie $z$ tym poradzić, kogo i za co chciałby przeprosić, a także co mu się podobało na zajęciach i co uważa za swój sukces. Ta część spotkania miała na celu zbliżenie ludzi do siebie przez większe zainteresowanie soba nawzajem i uczenie się rozmowy podczas spotkania, odsłaniania się przed innymi, co wymagało udzielenia sobie nawzajem pewnego kredytu zaufania oraz związanej $z$ tym odpowiedzialności za siebie i druga osobę.

4. Ostatnią formą kształcenia była realizacja tzw. zadania motywacyjnego, które wymagało od uczestników uzasadnionego wyboru samodzielnej aktywności ukierunkowanej na doskonalenie charakteru i rozwijanie konstruktywnych umiejętności. W trakcie rundy każdy mógł powiedzieć, co, dlaczego i w jaki sposób za- 
mierza zrobić w nadchodzacym tygodniu, aby osiagnać cel, który sobie wyznaczył. W zamian otrzymywał informacje zwrotne od pozostałych uczestników na temat tego, co i dlaczego jest dobre w tym, co sobie zaplanował, a co można jeszcze zrobić inaczej, żeby uzyskać większą efektywność. Na następnym spotkaniu każdy mógł zreferować, w jakim stopniu udało mu się osiagnąć zamierzony cel, i przeanalizować przyczyny sukcesu lub niepowodzeń, korzystajac przy tym $z$ opinii innych.

Warto nadmienić, że wzajemną komunikację uławiało siedzenie w kręgu, a ponadto więź pomiędzy uczestnikami powstawała nie tylko na skutek okazywanego sobie zainteresowania sprawami osobistymi każdego $z$ uczestników, ale także w efekcie współdziałania w parach podczas praktycznej realizacji wyznaczonych sobie zadań.

Część przygotowawcza kończyła się prezentacja przygotowanych przez studentów projektów warsztatów dla wychowanków placówek resocjalizacyjnych. Przez kolejne 5 miesięcy studenci, pracując w dwuosobowych zespołach, realizowali swoje autorskie programy wychowawcze $\mathrm{z}$ udziałem młodzieży niedostosowanej społecznie. Były to zajęcia $z$ dramy, psychodramy, street-art'u, hip-hopu i fotografii. Oprócz zadań stricte związanych $z$ działalnością artystyczną dużo czasu poświęcono na rozmowy $z$ wychowankami, zarówno indywidualne, jak i grupowe w formie podsumowującej każde spotkanie społeczności. Po zakończeniu 5-godzinnych zajęć studenci dzielili się między soba zdobytym doświadczeniem, udzielając sobie nawzajem informacji zwrotnych na podsumowującym każda wizytę w placówce spotkaniu pod kierunkiem opiekuna Koła.

Moja rola jako nauczyciela akademickiego sprowadzała się do inspirowania, doradzania, udzielania informacji zwrotnych zgodnie $z$ przyjętymi zasadami demokratycznego postępowania oraz przez stosowanie terapeutycznego stylu nauczania $\mathrm{w}$ fazie przygotowawczej i wyzwalającego w fazie praktycznej ${ }^{24}$.

${ }^{24}$ Oba style nauczania sa opisane w książce G.D. Fenstermacher, J.F. Soltis, Style nauczania, tłum. K. Kruszewski, WSiP, Warszawa 2000. 


\section{Rezultaty zastosowanych form kształcenia pedagogicznego w ramach pracy Koła Naukowego Resocjalizacji}

Celem zastosowanych form pracy ze studentami opierających się na dialogu było motywowanie oraz inspirowanie ich do podjęcia samokształcenia i samowychowania ukierunkowanego na kształcenie w sobie pożądanych cech i umiejętności wychowawczych, a także refleksji nad tym, jak powinna wyglądać praca $z$ młodzieżą niedostosowaną społecznie.

Badania jakościowe prowadzone w trakcie oraz po zakończeniu całego cyklu kształcenia miały na celu uzyskanie odpowiedzi na pytanie, czego ucza się studenci w wyniku aktywnego uczestnictwa w Kole Naukowym Resocjalizacji. Prezentowane w tym artykule wyniki dotycza jedynie wpływu zastosowanych form pracy na rozwój cech i kompetencji warunkujących umiejętność tworzenia przez wychowawcę dialogicznej relacji wychowawczej zgodnie $z$ przyjętymi przeze mnie założeniami. W tym celu zastosowałem technikę wywiadu. Przygotowane przeze mnie pytania, jak i analiza uzyskanych wypowiedzi ukierunkowane były na identyfikowanie zmian w posiadanej wiedzy, przekonaniach, umiejętnościach i postawach, które dostrzegaja w sobie studenci w związku z uczestniczeniem w zorganizowanych dla nich zajęciach w Kole Naukowym Resocjalizacji. W tym celu po zakończeniu całego cyklu szkolenia zadałem każdemu $z$ nich podczas indywidualnych wywiadów ewaluacyjnych następujące pytania: Czego nauczyłaś się przez uczestnictwo w spotkaniach Kola Naukowego Resocjalizacji? Czego dowiedziałaś się o sobie i jakie zmiany w sobie dostrzegasz po zakończeniu pracy w Kole? Na czym powinna polegać Twoim zdaniem relacja wychowawcy $z$ wychowankiem? Na podstawie analizy udzielonych wypowiedzi doszedłem do następujących wniosków.

Dla wielu studentów dużym wyzwaniem było wykazanie się systematycznością i odpowiedzialnościa w przygotowywaniu się do zajęć szkoleniowych na uczelni, jak również prowadzonych przez nich w ośrodku warsztatów $z$ wychowankami. Było to dla nich okazja do przekonania się, na ile sa już dojrzałymi odpowiedzialnymi osobami, a ile jeszcze muszą włożyć pracy w rozwijanie w sobie tej sprawności moralnej. Znamienna jest w tym względzie wypowiedź Studentki 1, która kilkakrotnie przy organizowaniu zajęć wspólnie $z$ koleżanką zawiodła jej oczekiwania, nie 
wywiąując się z wcześniej podjętych zobowiązań. Po zakończeniu warsztatów stwierdziła ona, że:

\begin{abstract}
praca $z$ koleżanka, z która prowadziłam zajęcia dla wychowanków, pokazała mi gdzieś tam na początku, że jestem mało odpowiedzialna, bo yyyy, $\mathrm{mmmm}$, ... ciężko nam było np. uzgodnić sobie termin na spotkanie $z$ nia przed pierwszymi zajęciami, ale pewnie mogłabym zrobić to tydzień wcześniej, a nie tuż przed samym wyjazdem do ośrodka. Przez to, jak widziałam zaangażowanie Marioli, jej odpowiedzialność, a czasem perfekcjonizm, to skłaniało mnie to do takiej autorefleksji, że ja też tak powinnam, jeśli chcę w przyszłości pracować w resocjalizacji. Nauczyłam się wtedy, że trzeba dać jeszcze więcej od siebie, niż myślałam - zaangażowania, wkładu pracy, nie wiem - wszystkiego. Dowiedziałam się wtedy, że muszę cały czas pracować nad tym, żeby robić wszystko dużo bardziej skrupulatnie, żeby być właśnie takim odpowiedzialnym. I że muszę być odpowiedzialna, a nie spontaniczna, bo spontanicznością nic nie zdziałam, że nawet jeżeli ktoś jest kreatywny, to jeżeli nie połączy tego $z$ zaangażowaniem, $z$ tą odpowiedzialnościa, a nie ze spontanicznościa, to i tak nic nie zdziała. A wcześniej myślałam, że zdziała (Studentka 1).
\end{abstract}

Niestety, nie można co prawda stwierdzić na podstawie obserwacji, że diametralnie zmieniło się jej podejście do obowiązków wynikających $z$ podejmowanych zobowiązań, ale cenne jest to, że dostrzega już w wyniku współpracy z koleżanka potrzebę takiej zmiany w sobie, czego wyrazem były podejmowane przez nią próby zmiany swojego zachowania. Dużą rolę w uświadomieniu sobie znaczenia, jakie odgrywaja w działalności wychowawczej sprawności moralne, w tym wypadku odpowiedzialność, miała też otwarta komunikacja pomiędzy obiema studentkami. Jest to zapewne efekt rozmów prowadzonych podczas organizowanej w okresie szkoleniowym społeczności, na której studenci byli zachęcani do odważnego, ale też taktownego mówienia o dostrzeganych błędach w postępowaniu pozostałych uczestników. Uczyli się w ten sposób, jak można rozwiazywać sytuacje konfliktowe za pomoca dialogu $z$ druga osobą.

O świadomości znaczenia kondycji moralnej wychowawcy w pracy resocjalizacyjnej świadczy również wypowiedź innej studentki, która zwraca uwage na uczciwość w relacjach interpersonalnych:

ważna jest autentyczność, żeby być sobą i nie udawać kogoś, kim się nie jest, żeby zachowywać się autentycznie i to właśnie też jest związane $z$ emocjami, żeby pokazywać te emocje, o w taki sposób, jak wcze- 
śniej już powiedziałam, to nie będę powtarzać, żeby pokazywać, ymm - wartość w tym, jakim się jest, żeby dawać dobry przykład drugiej osobie, ale też nie prowadzić do takiej sytuacji, że manifestuję coś, w co nie wierzę. Mówię o czymś, w co nie wierzę, przez co staję się osoba fałszywą w pewien sposób (Studentka 2).

Oprócz pracy nad doskonaleniem w sobie sprawności moralnych innym pozytywnym efektem udziału w opisywanych zajęciach szkoleniowych była wzrastajaca u większości studentek zdolność do krytycznej refleksji nad własnym postępowaniem. Jedna $z$ uczestniczek mówiła o tym w następujących słowach:

na pewno zwiększyła mi się jeszcze refleksyjność, dużo przemyśleń pojawia mi się przed i po zajęciach, np. żeby nie popełnić jakiegoś błędu, staram się dużo myśleć, mieć zawsze jakieś alternatywy, przemyśleć już jakieś argumenty wcześniej, żeby... jeżeli wiem, że była jakaś rozmowa albo sytuacja, żeby jej nie pominąć i też ją omówić i nie dawać tym samym takiego przyzwolenia, żeby działy się jakieś złe rzeczy, bo to jest bardzo ważne.

No i właśnie takim priorytetem jest rozwaga i refleksja, żeby mieć świadomość, że ja moge popełnić błąd i nie wszystko wiem, nie wszystko mogę zrobić dobrze i podejmować refleksję. Cały czas praktycznie, a nie tylko jak się coś stanie. Nawet jeżeli nic złego się nie dzieje, to rozważać, prowadząc obserwację wychowanka, to zastanawiać się, dlaczego on może się tak zachowywać, łączyć niektóre fakty, a jeżeli czegoś nie wiem, to starać się tak ukierunkować obserwację, żeby się tego dowiedzieć i być wyczulanym na to, czego próbuję się dowiedzieć.

$Z$ ta refleksja to jeszcze chodziło mi o to, żeby wszystko było przemyślane. Bo jakieś kroki mogą wyrządzić krzywdę wychowankom, a oni sa już wystarczająco skrzywdzeni przez środowiska, $z$ których pochodza, i jak czegoś nie przemyślę, to mogę ich jeszcze bardziej zranić i moga się zamknąć na otoczenie, na świat. Nie mówić, że ja jestem nieomylna, tylko żeby swoja postawa pokazać „OK, zrobiłam błąd”, przyznać się do tego, przeprosić, poprawić i pokazać, że tak powinno się robić (Studentka 3).

Sądzę, że duży wpływ na rozwijanie się tej zdolności miały wszelkiego rodzaju dyskusje i omówienia, które towarzyszyły podejmowanym przez studentów działaniom, zarówno w fazie szkoleniowej przy wykonywaniu symulacji, jak i po przeprowadzonych przez nich zajęciach $z$ wychowankami w placówce resocjalizacyjnej. 
Przygotowanie studentów do samodzielnego prowadzenia zajęć z wychowankami przyczyniało się do wzrostu pewności siebie oraz ich kreatywności. Wiązało się to również $z$ doskonaleniem umiejętności komunikacyjnych oraz empatii, co jak wyżej wspomniano, stanowi efekt rozwoju inteligencji emocjonalnej. Potwierdzaja to zarówno obserwacje ich zachowania na zajęciach przygotowawczych na uniwersytecie, jak i podczas pracy resocjalizacyjnej w placówce. O świadomości zwiększających się kompetencji w zakresie empatii, asertywności i komunikacji świadczy też następująca wypowiedź Studentki 3:

dowiedziałam się, że są sytuacje, w których nie sądziłam, że mogę być asertywna, a byłam. Jak trzeba było powiedzieć: „Chłopcy, nie zajmujemy się teraz tym, trzeba zrobić coś innego, przecież wiecie, że przyjechałyśmy po to, żeby zrobić to i to...”. A nie raz chcieli wyjść na spacer, a wiedziałam, że to wyjście nam wszystko rozwali, bo jesteśmy $\mathrm{w}$ trakcie pisania tekstu, ale wtedy to był taki kompromis - dobrze, pójdziemy, ale np. na „społeczności”. Nauczyłam się odmawiać w taki sposób, żeby oni mieli poczucie, że nie zbywam ich, tylko daję im możliwość zrealizowania tego później [...]

I na pewno przez te wszystkie wyjazdy do ośrodków stałam się taka bardzo otwarta do chłopaków. Potrafię podejść do wychowanka, usiasść obok niego i zapytać „O, co taki smutny? Czemu siedzisz sam?” i tak zainteresować się, wyłapać te osoby, z którymi naprawdę coś jest nie tak emocjonalnie. Na przykład $z$ Kacprem była taka trudna rozmowa. Teraz tak dokładnie jej nie pamiętam, bo to też tak było, że ja miałam wtedy też dużo emocji w sobie, ale ucieszyłam się, że wyszedł $z$ tej rozmowy taki odciążony i uśmiechnięty. I widać było już na następnych zajęciach, że się czuje lepiej. Bardzo byłam zadowolona, że w ogóle chciał rozmawiać i że udało się nakierować tak tę rozmowę, że sam dochodził do takich wniosków, że to, co planuje, czyli z powrotem spróbować się zabić, nie jest najlepszym rozwiązaniem (Studentka 3).

Wydaje się, że duży wpływ na rozwój umiejętności dostrzegania przeżywanych przez wychowanka emocji i adekwatnego reagowania na nie miały powtarzajace się na początku każdego spotkania Koła barometry nastroju, kiedy studenci otwarcie mówili o własnych emocjach $i$ uczyli sie właściwej reakcji na nie. W przypadku tej studentki pozytywna role odegrała również realizacja zadania poświęconego znaczeniu, rodzajom oraz sposobom odczytywania, komunikowania i regulowania odczuwanych przez ludzi emocji. 
$Z$ założenia prowadzone kształcenie pedagogiczne studentów miało na celu inspirowanie ich do świadomej realizacji koncepcji resocjalizacji opierającej się na wartościach humanistycznych oraz dialogu wychowawczym. Nie wszystkim w jednakowym stopniu udało się skrystalizować swoje poglądy w spójna koncepcję, która potrafiliby rozwijać w praktyce. Byli jednak wśród nich tacy, którzy po zakończonym cyklu kształcenia przygotowawczego i praktycznego na temat relacji wychowawczej pomiędzy wychowawcą a wychowankiem wypowiadali się w następujący sposób:

Ja to widzę tak? Yyy..., że wychowanek jest moim partnerem, z którym idę razem i tworzymy zespół. Ja się nie wywyższam, nie jestem ważniejsza, nie myślę o sobie, tylko głównym celem jest pomoc wychowankowi. Ja uczę się od niego, on uczy się ode mnie. To jest taka wzajemność, że nie tylko ja wymagam, ale oboje możemy coś dla siebie zrobić. Owszem, on może wymagać, ale ja też, i to trzeba zrównoważyć. Należy brać pod uwagę, jeśli wychodzi z jakaśs inicjatywą, jeżeli widzę, że ma jakieś predyspozycje, to żeby wydobywać to $z$ niego, iść $w$ tym kierunku, żeby go wzmacniać w tym, w czym jest dobry, żeby mógł sie rozwijać, no i żeby miał takie poczucie sprawczości, że potrafi coś, że nie jest tylko tym złym, który wiecznie miał wpajane do głowy, że jest ten najgorszy - nic nie potrafi, tylko żeby dostrzec w nim to dobro i żeby on nauczył się właśnie poprzez taka relację też dostrzegać dobro w innych i w sobie. No na pewno takiej relacji nie widzę bez zaufania, które jest taka podstawa. Wiadomo, że to też potrzeba czasu, żeby zbudować to zaufanie, ale jeżeli będę autentyczna i będę miała zawsze dla wychowanka czas, będę umiała empatycznie do niego podejść, będziemy mieli jasne zasady określone przez nas oboje - nie tylko że ja narzuce zasady, ale oboje będziemy mogli wspólnie je wypracować. No i będę szanowała jego godność, będę traktowała go podmiotowo, co na pewno wpłynie na to, że zobaczy, że mam taka postawę, i będzie mógł mi zaufać. Ja będę dochowywała tajemnicy, jeżeli nie będzie mu się działa krzywda, bo wiadomo, że są sytuacje, o których też mu powiem, że „OK, to mogę zachować dla siebie, ale jeżeli jest sytuacja, która zagraża Twojemu życiu, to muszę to zgłosić ze względu na to, że musze i chcę dbać o Twoje dobro". Nawet może się wtedy obrazić, ale dobro jego jest dla mnie priorytetem i też żeby przedstawić to jasno, żeby nie było, że nie można mi zaufać i nie dochowuję dyskrecji. No właśnie chciałabym być bardzo autentyczna w tej relacji, bo kłamstwo ma krótkie nogi, nic na tym nie zyskam, a tylko stracę. Co do tej relacji to ważne dla mnie będzie, żeby znaleźć czas na rozmowę wtedy, kiedy wychowankowie tego potrzebują. Żeby wiedzieli, że jestem dla nich i w miarę możliwości będę ich wspierać, żeby doprowadzać ich do samodzielności, do tego, żeby 
potrafili sami stanowić o sobie, sami podejmować decyzję, uczyć się nawet na swoich błędach, bo wiadomo, że wtedy uczymy się najszybciej. Będą mogli otrzymywać ode mnie cenne wskazówki na tyle, na ile będę w stanie przewidzieć, żeby nie wpakowali się w jakieś bardzo duże kłopoty. No i właśnie chodzi mi o to współdziałanie, żebyśmy szli przez to razem, żebym nie była wychowawca, który siedzi w kantorku od do, tylko żeby chłopcy wiedzieli, że nie przychodzę po to, żeby zarobić tylko pieniądze, ale po prostu przychodzę, bo chcę przebywać $z$ nimi i jestem dla nich, żeby to czuli - tak to widzę (Studentka 3).

W przypadku tej studentki na dojrzałość jej poglądów wpłynęło powiązanie wiedzy teoretycznej $z$ działalnościa praktyczną. Otóż tutaj pozytywny efekt przyniosło czytanie literatury naukowej wprowadzajacej do zadań realizowanych na zajęciach w Kole. Wiedza ta została przez nia wykorzystana również w trakcie samodzielnej pracy $z$ wychowankami podczas realizowania autorskiego projektu resocjalizacji. Ale najbardziej cenne jest to, że głoszone przez nia poglądy na temat wychowania znajdowały swoje odzwierciedlenie w postawach zajmowanych wobec wychowanków oraz innych osób, z którymi współpracowała w ramach zajęć organizowanych w Kole Naukowym Resocjalizacji. Ta konstatacja znajduje również swoje potwierdzenie w dalszym fragmencie jej wypowiedzi:

Akurat jak czytałam o empatii, to mi tak uświadomiło, jak bardzo jest to ważne i zapominane przez ludzi, bo wszyscy się śpieszą, a już tym bardziej pomyśleć, jak ktoś inny się czuje - przecież ja jestem najważniejszy. Taka refleksje przeżyłam. Dużo książek wtedy przeczytałam na temat empatii i emocji. Czytałam też o emocjach u Golemana i moja wiedza bardzo się poszerzyła dlatego, że to, co czytałam, bardzo powielało się $z$ ta praca, która na Kole robiliśmy. A teraz czytam dużo o dialogu w resocjalizacji i teraz widze, jak to się łączy i stosuje w praktyce. Im więcej książek czytałam, to na początku płacz był niesamowity, bo filozofia, ciężko było przez to przebrnać. Ale $z$ odpowiednia motywacją Pana doktora udało się. Przeczytałam i zrozumiałam. No i pojawiła się taka satysfakcja, że wiem więcej od części studentów, którzy sa tutaj na studiach, bo nawet tych książek by nie przeczytali. Sama bym zrezygnowała po pierwszym przeczytaniu. Musiałam kilka razy czytać, żeby to zrozumieć, ale tak naprawdę to, co przeczytałam, i to, jak pracujemy na Kole, uformowało to, że chciałabym być takim wychowawca dialogu, że to jest właśnie takie dobre w wychowaniu i tak powinniśmy postępować w relacji z każdym drugim człowiekiem. Nieważne, czy to w ośrodku, czy w domu, czy na ulicy, zamierzam to pielęgnować i przekazywać dalej (Studentka 3). 


\section{Podsumowanie}

Analiza wywiadów przeprowadzonych ze studentami uczestniczacymi z zajęciach Koła Naukowego Resocjalizacji wykazała, że zastosowane formy pracy ukierunkowane na kształtowanie w nich cech i kompetencji warunkujących zdolność do nawiązywania relacji dialogicznej przyniosły oczekiwane rezultaty. Tym samym można przyjać, iż zaproponowana formuła pracy ze studentami może być jedn $\mathbf{z}$ bardziej efektywnych metod kształcenia umożliwiajaca przynajmniej niektórym $z$ nich osiaganie wysokiej świadomości, dojrzałości i satysfakcji pedagogicznej w wyniku rozwijania w sobie sprawności moralnych, krytycznej refleksji, inteligencji emocjonalnej oraz kompetencji społecznych. Pogłębianie wiedzy w wyniku studiowania literatury pedagogicznej wraz z możliwościa jej praktycznej implementacji stwarza również warunki do weryfikacji swoich możliwości i ograniczeń, a także oczekiwań. Dzięki temu nauczyciele akademiccy mają również większą i bardziej rzetelną możliwość dokonywania odpowiedzialnej selekcji wśród kandydatów do zawodu wychowawcy, czego brakuje w coraz bardziej skomercjalizowanej rzeczywistości społeczno-kulturowej, w tym również edukacyjnej. O potrzebie odpowiedzialnego kształcenia kandydatów na wychowawców resocjalizacyjnych przekonuja bowiem wyniki badań, które wskazuja, że „w tych ogólnie pozytywnych relacjach wychowawców $z$ wychowankami mało jest jednak szczerej, otwartej komunikacji, bliskiego kontaktu oraz swobody i bezpieczeństwa"25, a niska zdolność do autorefleksji większości wychowawców powoduje, że zawyżaja oni poziom posiadanych kompetencji praktyczno -moralnych oraz technicznych.

Przyczyn tego kryzysu wychowawczego, który negatywnie odciska swoje piętno na tożsamości zawodowej nauczycieli i wychowawców, można zdaniem Henryki Kwiatkowskiej upatrywać m.in. w

destrukcji więzi między nauczycielem a uczniem, jaka nastapiła w ciagu ostatnich 20 lat. Uległa ona radykalnemu urzeczowieniu. Im wyższy szczebel edukacji, tym większa depersonalizacja i tym większa przepaść między światem ucznia i nauczyciela. Ta przepaść powoduje szczelną

25 A. Karłyk-Ćwik, Kompetencje pedagogów w pracy z nieletnimi agresorami, Akapit, Torun 2009, s 284. 
blokadę emocjonalną, którą tworzy gradacja uczuć, poczynając od zwy-

kłej obojętności poprzez obcość do wrogości włącznie ${ }^{26}$.

W pewnym stopniu skutecznym remedium na powstrzymanie tego kryzysu wydaje się rozwijanie u wychowawców umiejętności budowania relacji dialogicznej $z$ wychowankiem, czego przykładem sa opisane formy pracy ze studentami w ramach działalności Koła Naukowego Resocjalizacji.

Słowa kluczowe: dialog, kształcenie pedagogiczne studentów, kompetencje wychowawcze

\title{
DIALOGUE IN PEDAGOGICAL TRAINING OF SOCIAL REHABILITATION STUDENTS
}

\begin{abstract}
Summary
The first part of this article contains description of the role of dialogue in upbringing and the own conception of educator's features and competencies which it has to do with education in dialogue. The second part relates to the effects of dialogical forms which were applied by author in student's education at university. Qualitative analysis of interviews with students revealed that such forms of education allow them to notice favorable changes in their development. In their opinion the participation in that form of education help them become more responsible, assertive, communicative, empathetic, critical and improve their subjective treatment of socially unsuited young people.
\end{abstract}

Keywords: dialogue, pedagogical training at university, educational competences

Translated by Hubert Kupiec

${ }^{26}$ H. Kwiatkowska, Tożsamość wychowawcy, w: Wychowanie. Pojęcia..., s. 27. 



\section{Regina Pazdur}

Uniwersytet Ślaski

\section{Student/studentka pedagogiki człowiekiem (bez) nadziei?}

\section{Wprowadzenie}

W ostatnich latach „nadzieja” występuje coraz częściej w polskim dyskursie pedagogicznym, jednak nie znalazła się ona w żadnym opracowaniu słownikowym i podręcznikowym ${ }^{1}$, nie mówiąc już o szerokim ujęciu nadziei w kontekście wychowania do nadziei. Jedyna praca $a^{2}$ zatytułowana wprost Wychowanie do nadziei jest artykuł z zakresu teorii wychowania autorstwa Katarzyny Olbrycht zamieszczony w „Fides et Ratio”. Pedagogika nadziei w ujęciu personalistyczno-chrześcijańskim zajmuje się m.in. Stanisław Chrobak ${ }^{4} . Z$ kolei Wiesław Andrukowicz ${ }^{5}$ proponuje dydaktyczna „strategie dobrej nadziei”. Anna Murawska ${ }^{6}$ postrzega edukację jako troskę o nadzieję człowieka i podejmuje temat nadziei w sposób interdyscyplinarny. Innymi polskimi autorami zajmujacymi się nadzieja m.in. w kontekście wychowania, edukacji i pedagogiki są: Józef Kozielecs. 282 .

1 A. Murawska, Edukacja jako troska o nadzieje człowieka, Wyd. US, Szczecin 2011,

2 Jedyną w tym kontekście, którą udało mi się odnaleźć podczas studiów nad tematem wychowania do nadziei.

3 K. Olbrycht, Wychowanie do nadziei, „Fides et Ratio” 2010, nr 2, s. 39-46.

4 S. Chrobak, Podstawy pedagogiki nadziei, Wyd. UKSW, Warszawa 2009; idem, Nadzieja jako dynamizm rozwoju i egzystencji człowieka, „Seminare” 2008, t. XXVIII, s. 329340; idem, Nadzieja nadzieja chrześcijańskiej (i nie tylko) pedagogiki, „Roczniki Pedagogiczne" 2009, t. I, s. 19-37.

5 W. Andrukowicz, Strategia dobrej nadziei, „Edukacja i Dialog” 2004, nr 5, s. 4-10.

6 A. Murawska, Edukacja jako troska..., passim. 
$\mathrm{ki}^{7}$ (psycholog), Jacek Mesterhazy ${ }^{8}$ (psycholog kliniczny), Józef Tischner (filozof), Tadeusz Frackowiak ${ }^{9}$ (pedagog społeczny). $Z$ liczby publikacji na omawiany temat w kontekście wychowania do nadziei wynika, iż problem ten nie doczekał się jeszcze należytego miejsca wśród zagadnień, jakimi zajmuje się współczesna pedagogika.

W Polsce na gruncie psychologii stworzono narzędzia diagnostyczne służące do badania poziomu nadziei podstawowej ${ }^{10}$ oraz nadziei na sukces. Jerzy Trzebiński i Mariusz Zięba są autorami opracowanego w latach 2001-2003 ${ }^{11}$ Kwestionariusza Nadziei Podstawowej BHI-12 ${ }^{12}$, Kwestionariusza Nadziei Podstawowej z 2009 roku BHI- $R^{13}$ oraz - wespół z Mariola Łaguna - Kwestionariusza Nadziei na Sukces ${ }^{14}$. Kwestionariusz

7 J. Kozielecki, Psychologia nadziei, Wyd. UKSW, Warszawa 2006; idem, Cywilizacja strachu czy kultura nadziei, „Nauka” 2007, nr 2, s. 7-18; idem, Od polityki impotencji do polityki nadziei, „Odra” 2007, nr 6, s. 8-15; idem, Polacy w poszukiwaniu nadziei, „Odra” 2008, nr 4, s. 14-20; idem, Nadzieja - klucz do sztuki życia, „Nauka” 2009, nr 2, s. 7-14.

8 J. Mesterhazy, Pedagogika nadziei, „Edukacja i Dialog” 1994, nr 8, s. 22-24.

9 T. Frackowiak, O pedagogice nadziei. Fascynacje i asocjacje aksjologiczne, Wydawnictwo UAM, Poznań 2007.

10 „Nadzieja podstawowa” to termin wywodzacy się z teorii rozwoju psychospołecznego Erika Eriksona. Nadzieja - zgodnie $z$ rozumieniem tego pojęcia przez Eriksona - to przeświadczenie jednostki o dwóch właściwościach świata (które są ogólne i ze sobą powiązane): świat jest uporzadkowany i sensowny, swiat jest generalnie przychylny człowiekowi. Nadzieja podstawowa nie ma charakteru czysto poznawczego - przejawia się zarówno w prognozowaniu biegu zdarzeń i sposobie ich interpretowania, jak i w uczuciach pojawiających się wobec (tych) zdarzeń. Nadzieja podstawowa jest uważana za względnie stabilna strukturę osobowości kształtującą się we wczesnej fazie rozwoju człowieka, jednak podlegająca pewnym zmianom w ciagu życia. Mechanizmy zmiany poziomu nadziei podstawowej maja inny rodzaj niż mechanizmy zmian opinii i postawy. Jest to spowodowane zarówno wczesna genezą nadziei podstawowej (zgodnie $z$ teoria Eriksona), jak i pozycji nadziei w globalnej wizji świata (nadzieja jest ważnym składnikiem owej wizji). Aby jednostka zmieniła swoje zdanie na temat sensowności i pozytywności świata, musi doświadczyć wydarzeń przełomowych, zarówno w kwestii skali danego przeżycia, jak i jego konsekwencji. Nadzieja podstawowa jest swego rodzaju kompetencja osobowości wpływająca na dane zachowanie w istotnych sytuacjach życiowych. J. Trzebiński, M. Zięba, Kwestionariusz nadziei podstawowej BHI-12. Podręcznik, Pracownia Testów Psychologicznych PTP, Warszawa 2003, s. 4-5.

11 J. Trzebiński, M. Zięba, Kwestionariusz BHI, http://nadziejapodstawowa.pl/ludzie/ (6.01.2015).

12 J. Trzebiński, M. Zięba, Kwestionariusz nadziei..., passim.

13 J. Trzebiński, M. Zięba, Kwestionariusz BHI, passim.

${ }^{14}$ M. Łaguna, J. Trzebiński, M. Zięba, Kwestionariusz nadziei na sukces, Pracownia Testów Psychologicznych PTP, Warszawa 2005. 
Nadziei na Sukces (KNS) ${ }^{15}$ to narzędzie będące polską adaptacja ${ }^{16}$ Adult Dispositional Hope Scale(ADHS) ${ }^{17}$ autorstwa Charlesa Richarda (Ricka) Snydera ${ }^{18}$. Dotychczas nie przeprowadzono kompleksowych badań dotyczących poziomu nadziei polskich studentów/studentek pedagogiki.

W niniejszym artykule zaprezentowane zostaną wyniki badań własnych ${ }^{19}$ przeprowadzonych w 2013 roku, dotyczacych m.in. poziomu nadziei na sukces ${ }^{20}$ studentów/studentek pedagogiki Wydziału Etnologii i Nauk o Edukacji.

\section{Zagadnienia metodologiczne badań własnych}

Przedmiotem badań autorki było m.in. określenie poziomu nadziei na sukces studentów/studentek pedagogiki studiujących na Wydziale Etnologii i Nauk o Edukacji w Cieszynie (WEiNoE) Uniwersytetu Śląskiego w Katowicach. Badania te wykonano, by zdiagnozować, jakimi zasobami nadziei na sukces dysponuja przyszli pedagodzy, określić ich po-

\footnotetext{
15 Ibidem, passim.
}

${ }^{16}$ M. Zięba, Kwestionariusz nadziei na sukces KNS. Podręcznik, http://www.researchgate.net/publication/259781631_Kwestionariusz_Nadziei_na_Sukces_KNS_podrcznik (1.06.2015).

${ }^{17}$ Skala ta nazywana była również Goals Scale (S. Lopez, R. Ciarlelli, L. Coffman, S. Stone, L. Wyatt, Diagnosing for Strengths. On Measuring Hope Building Blocks, w: Handbook of Hope Theory, Measures, and Applications, red. C.R. Snyder, Academic Press, San Diego 2000, s. 59), Future Scale i The Trait Hope Scale (C.R. Snyder, K.L. Rand, D.R. Sigmon, Hope Theory. A Member of the Positive Psychology Family, w: Handbook of Positive Psychology, red. C.R. Snyder, S. Lopez, Oxford University, New York 2002, s. 268).

${ }_{18}$ P. Kwiatek, Znaczenie i rozwój psychologii nadziei w ujęciu Charlesa Richarda Snydera, „Seminare” 2012, t. XXXI, s. 157-170.

${ }^{19}$ Autorka w 2013 r. obroniła na Wydziale Etnologii i Nauk o Edukacji w Cieszynie, Uniwersytetu Śląskiego w Katowicach pracę licencjacką Wychowanie do nadziei. Student pedagogiki człowiekiem (bez)nadziei (promotor prof. dr hab. Tadeusz Lewowicki).

20 Tłumacząc na język polski definicje "nadziei na sukces” - autorstwa Amerykanina Charlesa Richarda Snydera - Piotr Kwiatek pisze, iż tak rozumiana nadzieja jest to „dynamiczny i wielowymiarowy proces myślowy, składajacy się $z$ trzech integralnie połązonych elementów: celu (goal), sily (willpower) oraz drogi (waypower). [...] nadzieja to sposób myślenia, na który składaja się: suma motywacji (siła wewnętrzna i zewnętrzna) oraz konkretna strategia (droga) wiodaca do wyznaczonego celu. Wszystkie trzy komponenty są niezbędne i wpływają na jakość nadziei, czyli: wyraźne określenie celu - punkt dojścia, cel dążenia, siła - energia, motywacja, determinacja wewnętrzna, oraz określony plan realizacji danych zamierzeń - strategie, wizje, drogi”. P. Kwiatek, Znaczenie i rozwój..., s. $159-160$. 
ziom nadziei, sposób rozumienia pojęcia „nadzieja” oraz poznać opinie dotyczace podejmowania tematu nadziei podczas studiów. Poziom nadziei osób znaczacych (w tym nauczycieli-wychowawców) ma diametralne znaczenie w kształtowaniu nadziei uczniów, może m.in. przyczynić się do zmniejszenia poczucia beznadziejności u dzieci oraz mieć charakter profilaktyczny.

Sformułowano następujące problemy badawcze:

1. Jakim poziomem "siły”21 (will power/path ways thoughts) - elementu składowego nadziei na sukces - dysponuja studentki pedagogiki WEiNoE Uniwersytetu Śląskiego w Cieszynie?

2. Jakim poziomem „drogi”22 - elementu składowego nadziei na sukces - dysponują studentki pedagogiki WEiNoE Uniwersytetu Śląskiego w Cieszynie?

3. Jak studentki pedagogiki WEiNoE Uniwersytetu Śląskiego w Cieszynie rozumieja pojecie „nadzieja”?

4. Jaki poziom nadziei na sukces maja studentki pedagogiki WEiNoE Uniwersytetu Śląskiego w Cieszynie?

Wybrana metoda badawcza zastosowana przez autorkę i pomocna w rozwiazywaniu problemów badawczych jest metoda sondażu. Do badania poziomu nadziei na sukces studentek pedagogiki wykorzystano profesjonalne narzędzie badawcze (mające postać kwestionariusza ankiety) skonstruowane przez Snydera w 1991 roku - Adult Dispositional Hope Scale (ADHS). Dodatkowo, chcac uzyskać informacje na temat rozumienia pojęcia nadziei przez respondentów oraz poznać ich opinie, dodano otwarte pytania kwestionariuszowe.

W przeprowadzonych w 2013 roku badaniach wzięła udział łączna liczba 140 studentek pedagogiki Uniwersytetu Śląskiego WEiNoE w Cieszynie (tabela 1).

${ }^{21}$ Siła (willpower/agencythoughts) w koncepcji Snydera to pewnego rodzaju energia umysłu związana z ogólna moca organizmu człowieka. Czynnik ten jest odpowiedzialny za inicjowanie, utrzymanie i doprowadzenie do końca danej aktywności umożliwiającej osiagnięcie celu. Umożliwia przejście z punktu, w którym aktualnie się znajdujemy, do punktu, jaki chcemy osiagnąć. Poziom siły jest związany $z$ charakterem danych pragnień oraz $z$ doświadczeniem człowieka. Ibidem, s. 161-162.

22 Droga (waypower/pathwaysthoughts) w koncepcji nadziei Snydera to wizja, planowanie, sposób, strategia. To zdolność umysłu zarówno do wyobrażenia i wizualizacji celów, jak i stworzenia konkretnych strategii, twórczych planów - szczegółowych i ogólnych - ich osiagnięcia. Ibidem, s. 162. 
Tabela 1. Charakterystyka liczbowa badanych osób

\begin{tabular}{|c|c|c|c|}
\hline \multicolumn{4}{|c|}{$\begin{array}{l}\text { Liczba studentek pedagogiki (bioracych udział w badaniu) } \\
\text { studiujących na WEiNoE UŚ w Cieszynie }\end{array}$} \\
\hline \multirow[b]{2}{*}{$\begin{array}{l}\text { Specjal- } \\
\text { nośćność }\end{array}$} & \multicolumn{2}{|c|}{ w trybie stacjonarnym } & \multirow{2}{*}{\begin{tabular}{|c|}
$\begin{array}{c}\text { w trybie niestacjonar- } \\
\text { nym }\end{array}$ \\
$\begin{array}{c}\text { Studentki III roku stu- } \\
\text { diów studiów pierwsze- } \\
\text { go stopnia } \\
\text { (3 lic, SN) }\end{array}$ \\
\end{tabular}} \\
\hline & $\begin{array}{l}\text { Studentki I roku studiów } \\
\text { pierwszego stopnia } \\
(1 \text { lic }, \mathrm{SS})\end{array}$ & $\begin{array}{l}\text { Studentki I roku stu- } \\
\text { diów drugiego stopnia } \\
\text { (1 mgr/4, SS })\end{array}$ & \\
\hline POW & 17 & 11 & 0 \\
\hline ZEWiWP & 12 & 49 & 33 \\
\hline ASK & 11 & 0 & 0 \\
\hline TPiAON & 7 & 0 & 0 \\
\hline Suma & 47 & 60 & 33 \\
\hline Razem & & 140 & \\
\hline
\end{tabular}

POW - Pedagogika Opiekuńczo-Wychowawcza

ZEWiWP - Zintegrowana Edukacja Wczesnoszkolna i Wychowanie Przedszkolne

ASK - Animacja Społeczno-Kulturalna

TPiAON - Terapia Pedagogiczna i Asystent Osoby Niepełnosprawnej

Źródło: opracowanie własne.

\section{Wyniki badań}

Osoby badane - oprócz wypełnienia kwestionariusza ADHS - odpowiedziały na pytania otwarte m.in. dotyczące podejmowania tematu nadziei na zajęciach w okresie studiów. Spośród 140 osób badanych $108(77,14 \%)$ jest zdania, iż w toku studiów nie podejmowano tematu nadziei („nie”, „raczej nie”, „nie sądzę), 12 osób (8,57\%) nie przypomina sobie, czy podejmowano temat nadziei, czy nie („nie pamiętam”, „nie przypominam sobie"). Pojedyncze badane osoby wskazywały na: psychologię, psychologię rozwojowa, filozofię, teoretyczne podstawy wychowania, socjologię, edukację wczesnoszkolna jako przedmioty, na których poruszano temat nadziei. Jedna osoba zauważyła, iż temat nadziei poruszany był na wielu przedmiotach (w kontekście nadziei na osiagnięcie różnych celów).

Interesujące wydają się być wyniki badań dotyczących sposobów postrzegania i rozumienia pojęcia „nadziei” przez respondentki. Dla studen- 
tek I roku studiów pierwszego stopnia studiujących $\mathrm{w}$ trybie stacjonarnym (1 lic, SS; $N=47$ ) pojęcie nadziei związane jest $z$

1. Pozytywnym myśleniem i podejściem do życia, specyficznym stanem umysłu, uczuciem, chęcią dążenia do celów (44,70\%). Przykładowe opinie ${ }^{23}$ : nadzieja to „pozytywne podejście do życia i chęć dażenia do celu, umiejętność nie poddawania się”; „uczucie podtrzymujące "drogę" do zmierzającego celu”; „życiowy pozytyw”; „pozytywne myślenie w danej sytuacji, poczucie, że coś może się zmieni”; „uczucie pewnej pomyślności, uczucie, że wszystko się uda, że wszystko będzie dobrze”; „uczucie dające możliwość spokojnego dążenia do celów”; „myśl na lepszą przyszłość, coś co się dzieje w naszym umyśle, coś co byśmy chcieli bardzo mocno, ale nie wiadomo czy się spełni”; „myśl podtrzymująca w nas chęć działania".

2. Szansa na lepsze jutro (dla 10,70\% badanych „nadzieja to szansa na lepsze jutro").

3. Oczekiwaniem $(10,70 \%)$. Przykładowe opinie: nadzieja to „wytrwałe, czasem naiwne oczekiwanie na coś, co może nigdy nie nadejść”; „oczekiwanie, że stanie się coś, o czym od dawna marzymy”, „etap oczekiwania”.

4. Wiara $(8,50 \%)$. Przykładowe opinie: nadzieja to „wiara, że coś się uda”; „wierzenie, że uda nam się to co chcemy”; „wiara w dobre zakończenie danej sprawy czy sytuacji”; „wiara, że wszystko może się udać".

Ostatecznościa $(10,70 \%)$. Przykładowe opinie: nadzieja to „ostatnia deska ratunku”; „ostatnia szansa”; „ostateczność".

Pozostałych pojedynczych opinii $(4,7 \%)$ nie da się jednoznacznie zakwalifikować. Przykładowe opinie: nadzieja to „zielone światło”; „łudzenie się”; „ciąża”, „matka głupich”.

Studentki I roku, studiów drugiego stopnia studiujące w trybie stacjonarnym (1 mgr/4, SS; $N=60)$ utożsamiały nadzieję $z$ :

1. Wiara $(38,33 \%)$. Przykładowe opinie: nadzieja to "wiara na lepsze jutro”; „wiara, podstawa”; „wiara, która przyczynia się do osiagnięcia celu”; "coś w co wierzymy, że się uda”; „wiara w to, że to

${ }^{23}$ Zachowano oryginalna pisownię. 
w co wierzymy może się ziścić”; „wiara w poprawę sytuacji”; „wiara w to, że będzie dobrze".

2. Uczuciem $(11,57 \%)$. Przykładowe opinie: nadzieja to „uczucie, które każdy powinien mieć, sprawia, że dzięki niej udaje nam się przetrwać problemy życiowe”; „uczucie, które pozwala nie popadać w załamanie".

3. Stanem dającym siłę $(8,33 \%)$. Przykładowe opinie: nadzieja to „stan dający siłę, w którym znajduje się każdy człowiek, który jest przekonany o tym, iż osiagnie cel, który wcześniej założył"; „stan ducha”; „stan, który daje nam siłę by coś osiągnaćc; „coś co daje nam sile by osiagnać cel".

4. Pozytywnym myśleniem (8,33\%). Przykładowe opinie: nadzieja to „myślenie pozytywne. "Ratowanie się" pozytywnymi myślami nawet w sytuacjach beznadziejnych”; „pozytywna myśl, która pomaga w życiu dostrzec szanse na wiele możliwości".

5. Oczekiwaniem (6,67\%). Przykładowe opinie: nadzieja to „oczekiwanie na coś, żeby się spełniło”; „czekanie na to, że coś ważnego dla mnie się spełni”; „czekanie aż wydarzy się coś czego pragniemy, czekanie $z$ ufnościa na to co się ma wydarzyć".

6. Szansa na lepsze jutro (dla $5 \%$ badanych „nadzieja to szansa na lepsze jutro").

7. „Czymś”, co pozwala realizować marzenia (dla 5\% badanych „nadzieja to coś co pozwala realizować marzenia”).

8. „Czymś”, co wzbudza negatywne konotacje i jest fałszywa wartościa (5\%). Przykładowe opinie: nadzieja to "element, który niszczy moje życie”; „element w życiu, który niepotrzebnie wszystko komplikuje”; „wartość która pomaga tłumaczyć niewygodne zjawiska”; „fałszywa wartość”.

Dla pozostałych osób badanych $(11,77 \%)$ nadzieja utożsamiana jest z niedającymi się zakwalifikować $\mathrm{z}$ pozostałymi opiniami wyrażeniami: nadzieja to „matka głupich”, „towarzysz życia”.

$Z$ kolei studentki III roku studiów pierwszego stopnia studiujace $\mathrm{w}$ trybie niestacjonarnym (3 lic, $\mathrm{SN} ; \mathrm{N}=33$ ) utożsamiaja nadzieję $\mathrm{z}$ :

1. Wiara $(36,66 \%)$. Przykładowe opinie: nadzieja to „wiara w lepsze jutro”; „wiara”; „wiara w pomyślność zdarzenia”; „wiara, że wszystko będzie dobrze”; „moment wiary”. 
2. Pozytywnym myśleniem $(18,18 \%)$. Przykładowe opinie: nadzieja to „pozytywne patrzenie w przyszłość, optymistyczne spojrzenie na otaczający mnie świat i życie”; „sposób pozytywnego myślenia dotyczącego przyszłości".

3. „Czymś”, co trudno jednoznacznie określić (15,15\%). Przykładowe opinie: nadzieja to „złożona rzecz”; „ciężko jest to zdefiniować i jednoznacznie określić".

4. Dążeniem (dla 12,12 \% badanych "nadzieja to dążenie”; "dążenie do marzeń").

5. „Czymś”, co motywuje do działania $(12,12 \%)$. Przykładowe opinie: nadzieja to „motor do dalszych działań, do realizacji samego siebie, walki z trudnościami”; „motywacja do pokonywania trudności”.

Dla pozostałego odsetka osób nadzieja utożsamiana jest $z$ „siła potrzebną do życia".

Jedynie wśród studentek 3 lic, SN pojawiły się odpowiedzi świadczące o głębszej refleksji nad nadzieja, objawiające się stwierdzeniami: „trudno określić, złożona rzecz” itp. Wydaje się być uzasadnione przypuszczenie, iż może mieć to związek z podejmowaniem w tej grupie w toku studiowania tematu nadziei. Większość badanych dokonywała próby definicji nadziei „jednowymiarowo". Nie pojawiły się próby zbudowania szerszej (złożonej) definicji tego pojęcia. Zgodnie $z$ wynikami badań Józefa Kozieleckiego w sprawie potocznego rozumienia nadziei nadzieja rozumiana jest przez większość respondentów jako ta o charakterze pasywnym ${ }^{24}$ zarówno $\mathrm{w}$ aspekcie partykularnym ${ }^{25}$, jak i generatywnym ${ }^{26}$. Interesujące sa pojawiające się negatywne opinie dotyczące nadziei wśród studentek $1 \mathrm{mgr} / 4$, SS.

${ }^{24}$ Zarówno potoczne obserwacje rzeczywistości, jak i badania naukowe dowodza, iż większość ludzi właśnie w taki sposób postrzega nadzieję. „Nadzieja pasywna jest przekonanie, że po okresie biernego oczekiwania człowiek osiagnie pożądany wynik (cel) z określonym stopniem prawdopodobieństwa”. J. Kozielecki, Psychologia nadziei, s. 38-39.

${ }^{25}$ Nadzieja o charakterze partykularnym jest ukierunkowana na jeden określony cel, który sprawca chce osiagnąć w określonym miejscu, czasie i z określonym prawdopodobieństwem. Ibidem.

${ }^{26}$ „Nadzieja generalna jest trwałym, ogólnym przekonaniem, że w przyszłości, bliższej lub dalszej, zrodzą się nowe, ważne zadania, których rozwiązanie nasycone będzie pozytywnymi wartościami i dobrami. Pozwoli to osiagnąć doniosłe cele i załatwić osobiste oraz społeczne interesy. [...] Człowiek żyje według nadziei i w nadziei. Jego osobisty świat jest światem nadziei. [...] Nadzieja generalna pełni ważne funkcje w życiu człowieka. [...] Po pierwsze, 
Spośród osób badanych największy odsetek studentek $(26,67 \%)$ posiadających wysoki poziom omawianej składowej nadziei na sukces „siły” (will power/path ways thoughts) studiuje na I roku studiów drugiego stopnia (1 mgr/4 SS). Studentki I roku studiów pierwszego stopnia (1 lic, SS) uzyskały najmniejsze wyniki - 19,14\% z nich oznacza się wysokim poziomem „siły” (wykres 1).

\section{Element "sily" nadziei na sukces}

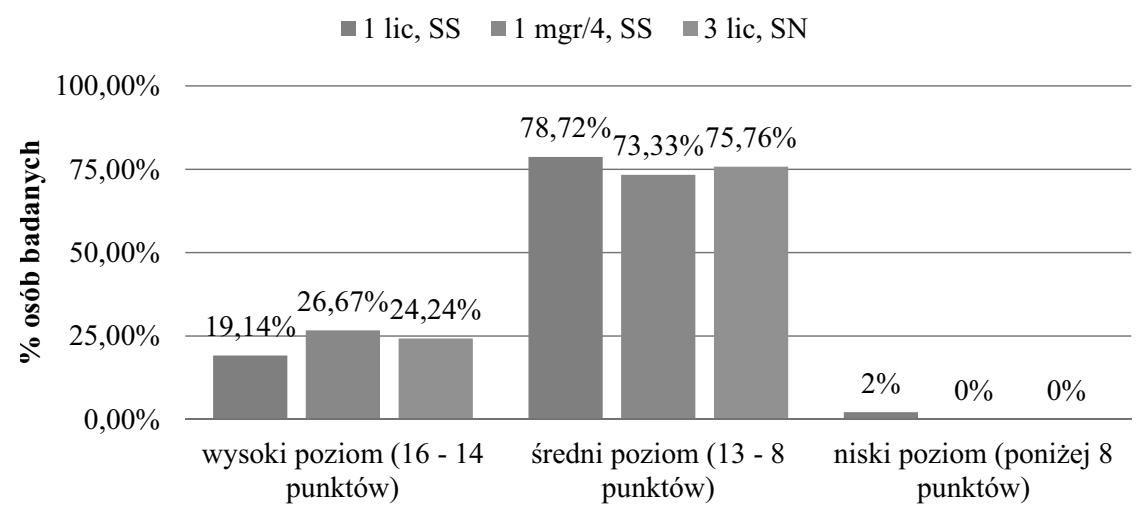

Wykres 1. Odsetek osób badanych uzyskujacych niskie, przeciętne i wysokie wyniki w Kwestionariuszu ADHS, w skali siły (will power/path ways thoughts) z podziałem na poziom studiów $(\mathrm{N}=140)$

Źródło: opracowanie własne.

23,57\% osób badanych posiada wysoki poziom „siły”, 75,72\% średni, a $0,71 \%$ niski poziom omawianej składowej nadziei na sukces (wykres 2).

wpływa na poczucie sensu życia, nawet w sytuacjach stresowych i niebezpiecznych. [...] Po drugie, nadzieja generalna wpływa na nadzieję partykularna. Gdy ta ostatnia zawiedzie, ta pierwsza broni przed rozpaczą i beznadziejnością. Pobudza motywację do poszukiwania innych, bardziej realistycznych celów, które nie przekraczają możliwości jednostki”. Ibidem, s. $40-42$. 


\section{Poziom "sily" - elementu składowego nadziei na sukces - studentek pedagogiki}

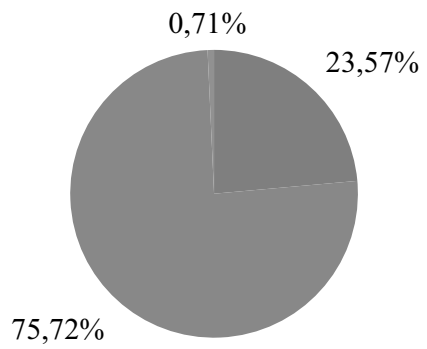

wysoki poziom

- średni poziom

niski poziom

Wykres 2. Odsetek osób badanych uzyskujących niskie, przeciętne i wysokie wyniki w Kwestionariuszu ADHS, w skali siły (will power/path ways thoughts) $(\mathrm{N}=140)$

Źródło: opracowanie własne.

Wynikiem minimalnym uzyskanym przez osoby badane był wynik 6 pkt, wynikiem maksymalnym był wynik 16 pkt. Wynikiem najczęściej występującym był wynik 12 pkt. Największe odchylenie standardowe $(\mathrm{s}=$ 1,65 ) występuje w grupie $1 \mathrm{mgr} / 4, \mathrm{SS}$; najmniejsze w grupie 3 lic, SN ( $\mathrm{s}=$ 1,29). Pośród studentek 1 lic, SS oraz $1 \mathrm{mgr} / 4$, SS 50\% uzyskało wynik 12 pkt lub mniej, pozostałe 50\% uzyskało wynik 12 pkt lub więcej $(\mathrm{Me}=$ 12). 50\% studentek 3 lic, SN uzyskało wynik 13 pkt lub mniej, pozostałe $50 \%-13$ pkt lub więcej.

Na wykresie 3 ukazano odsetek respondentek uzyskujacych wysoki, średni i niski wynik w Kwestionariuszu ADHS w skali „drogi” (way power/agency thought). $72,15 \%$ osób uzyskało średni, a 27,14\% wysoki wynik przy znikomym $(0,71 \%)$ procencie osób uzyskujących niskie wyniki. Studentki 3 lic, SN uzyskały największy procent wyników wysokich (45,45\%), przy czym 25,53\% studentek 1 lic, SS i 18,33\% studentek 1 mgr/4, SS uzyskało wynik wysoki (wykres 3). 


\section{Element nadziei na sukces - "droga"}

$\square 1$ lic, SS $\square 1 \mathrm{mgr} / 4, \mathrm{SS} \quad 3$ lic, $\mathrm{SN}$

$100,00 \%$

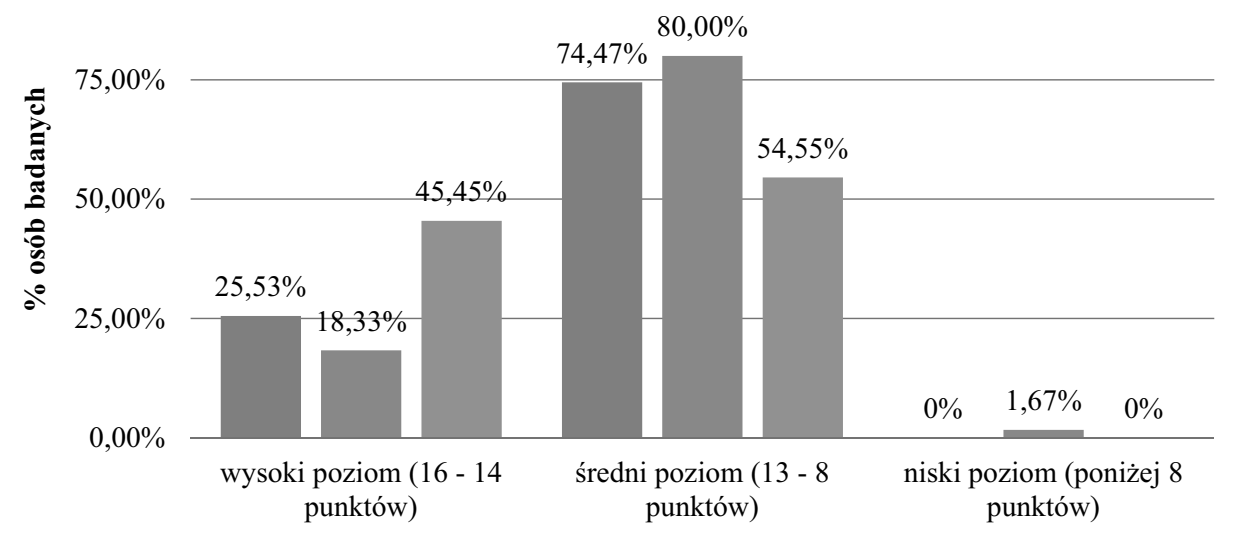

Wykres 3. Odsetek osób badanych (z uwzględnieniem poziomu studiów) uzyskujaccych niskie, przeciętne i wysokie wyniki w Kwestionariuszu ADHS, w skali drogi (way power/agency thought) $(\mathrm{N}=140)$

Źródło: opracowanie własne.

\section{Poziom "drogi" - elementu skladowego nadziei na sukces - studentek pedagogiki}

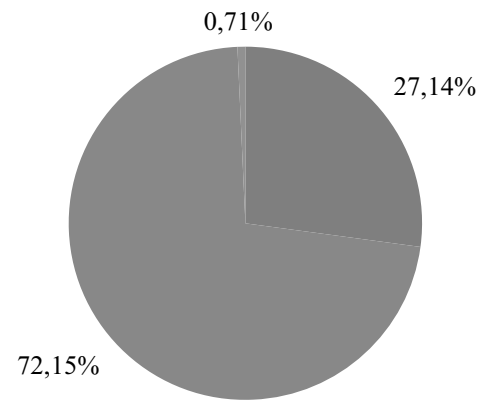

$$
\begin{aligned}
& \text { — wysoki poziom } \\
& \text { —średni poziom } \\
& \text { niski poziom }
\end{aligned}
$$

Wykres 4. Odsetek osób badanych uzyskujących niskie, przeciętne i wysokie wyniki w Kwestionariuszu ADHS, w skali drogi (way power/agency thought) $(\mathrm{N}=140)$

Źródło: opracowanie własne. 
$85,71 \%$ respondentek uzyskało wyniki wskazujące na średni poziom nadziei na sukces, a pozostały procent $(14,29 \%)$ badanych uzyskał wysoki wynik poziomu nadziei. Największy odsetek studentek uzyskujących wysoki wynik znalazł się w grupie 3 lic SN $(27,27 \%$ z nich uzyskało wysoki wynik przy pozostałych wynikach w granicach ok. 10\%). Żadna studentka nie uzyskała wyniku wskazującego na niski poziom nadziei (wykresy 5-6).

\section{Poziom nadziei na sukces}

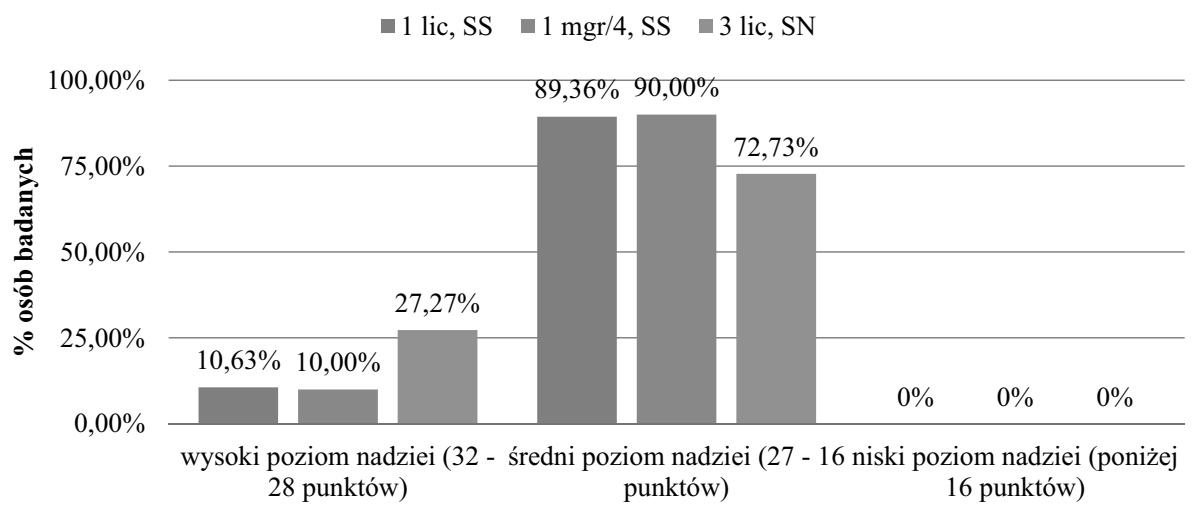

Wykres 5. Odsetek osób badanych posiadających wysoki, średni i niski poziom nadziei na sukces mierzonej Kwestionariuszem ADHS

Źródło: opracowanie własne. 


\section{Poziom nadziei na sukces studentek pedagogiki}

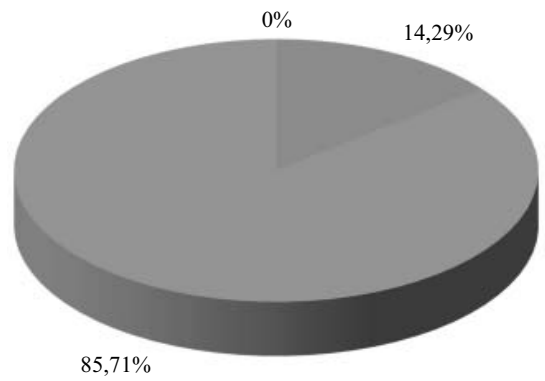

- wysoki poziom 32 - 28 punktów

- średni poziom 27 - 16 punktów

niski poziom poniżej 16 punktów

Wykres 6. Poziom nadziei na sukces studentek pedagogiki WEiNoE UŚ w Cieszynie mierzony kwestionariuszem ADHS $(\mathrm{N}=140)$

Źródło: opracowanie własne.

\section{Podsumowanie}

Żyjemy w czasach szybkich przemian, to, co wczoraj było nowościa, dziś przechodzi do szufladki „nieaktualna staroć”. Przez płynność i szybką zmienność świata przyszłość zatraca swoją wyrazistość, staje się nieprzejrzysta dla niektórych, po prostu rozmywa się. Na co dzień stykamy się $z$ różnego rodzaju realnymi i wyolbrzymianymi przez media, katastroficznymi wizjami przyszłości, zagrożeniami na skalę światowa (wystarczy wymienić terroryzm, klęski ekologiczne, przeludnienie, wizję zbrojnego zderzenia cywilizacyjnego, niewydolność systemu kapitalistycznego objawiająca się aktualnym kryzysem finansowym Europy i świata). Wydaje się, iż Wychowanie do Nadziei pozwala na korzystne dla rozwoju jednostki, umiejętne spojrzenie w przyszłość - bez niepotrzebnego i często hamujacego lęku. Pozwala na racjonalne i optymistyczne spojrzenie na własne życie w przyszłości, wyznaczanie ważnych celów, szukanie rozmaitych dróg dochodzenia do nich, a także wyposaża w umiejętność wyznaczania nowych celów i dróg w sytuacji, gdy jednostka staje w obliczu koniecznej zmiany wynikającej z niekorzystnej/korzystnej zaistniałej „tu i teraz” sytuacji. Wychowanie do Nadziei staje się filarem wychowania w ogóle. Zatem uzasadnione wydaje się stwierdzenie, iż studenci pedagogiki jako 
potencjalni przyszli nauczyciele powinni swoja postawą dawać nadzieję, nadzieję nieść i umieć ja budować, kształcić w wychowanku.

Mogłoby się wydawać, iż poczucie nadziei jest osobistą sprawą każdego człowieka. Tak zapewne jest, ale w przypadku nauczyciela, wychowawcy poczucie nadziei wychowawcy staje się również ważne dla przyszłych wychowanków, (nadziei można się bowiem nauczyć). Większość badanych studentek pedagogiki posiada średni poziom nadziei na sukces, jednak niepokojące wydają się być wyniki w skali wysokiego poziomu nadziei (mały odsetek respondentek ma wysoki poziom nadziei), niskie wyniki studentów rozpoczynających studia, duży odsetek osób niepotrafiących znaleźć wielu pomysłów na rozwiązywanie własnych problemów czy uzależnienie znajdowania dróg do rozwiąywania problemów od opinii innych na temat istnienia takich możliwości.

Studia nad zagadnieniem nadziei oraz badania własne pozwalaja na stwierdzenie, iż „nadzieja to "coś» więcej, niż można zbadać za pomoca dostępnych narzędzi badawczych" - stworzenie skutecznego narzędzia diagnozującego nadzieję w jej pełniejszym wymiarze wydaje się być możliwe. Świadczy o tym próba zbudowania nowego narzędzia diagnostycznego przez Shane’a J. Lopez’a Ph.D., wykładowce na Uniwersytecie w Kansas, pełniacego funkcję Senior Scientist i Research Director w The Clifton Strengths Institute. Badacz jest również zaangażowany w międzystanowe badania w USA prowadzone przez Instytut Gallupa (z siedziba w Waszyngtonie w USA) „Gallup Student Poll” badajace poziom nadziei na sukces, poziom zaangażowania w szkole i dobre samopoczucie amerykańskich uczniów (w 2014 roku w badaniach wzięło udział 2900 szkół i 875000 uczniów).

\section{STUDENTS OF PEDAGOGY PEOPLE WITH (NO) HOPE}

\section{Summary}

In this article we presented results of the study carried out in 2013. The subject of research the author conducted was, among other things, to determine the level of hope for success among the students of education at the Faculty of Ethnology and Sciences Education in Cieszyn (WEiNoE), University of Silesia in 
Katowice. These studies were performed to investigate what resources of hope for the success have future educators, to determine their level of hope, their way of understanding the concept of "hope" and to get to know their opinion about using the theme of hope during the study. Level of hope of influential people (including teachers-educators) has a diametric significance in forming the sense of hope in students, for example it helps to reduce the feeling of hopelessness in children and could be used prophylactically.

Keywords: hope, education for hope, diagnostic tools, Adult Dispositional Hope Scale (ADHS) 



\section{Teresa Joanna Andrzejewska}

Uniwersytet Szczeciński

\section{Uczelnia jako miejsce współpracy opiekuna naukowego/promotora i doktoranta}

\section{Wprowadzenie}

Trzy grupy wartości uznawane jako elementy stałe i trwałe edukacji akademickiej maja wpływ na jakość w procesie kształcenia: wartości naukowe, wśród których ważne miejsce zajmuje rzetelność badawcza, wartości dydaktyczno-wychowawcze obejmujacce także relacje między nauczycielami akademickimi i studentami, wartości obywatelskie, gdzie ważne jest dobro wspólne i zaangażowanie społeczne ${ }^{1}$. Osoby ceniące tradycję i etos akademicki wskazują na potrzebę chronienia owych wartości. Zajmuja ważne miejsce również w kształceniu doktorantów, gdzie niezmienna jest tradycja kształcenia w małych grupach, w trybie seminariów oraz indywidualnych konsultacji. Jest tak, mimo iż szkoła wyższa na przestrzeni wieków ulega zmianom niemal we wszystkich obszarach jej funkcjonowania ${ }^{2}$.

\section{Studia doktoranckie}

Studia doktoranckie moga być realizowane w trybie dwu- lub czteroletnim. Prawo o szkolnictwie wyższym reguluje tryb realizacji zajęć i sta-

1 S. Palka, Trwate i zmienne składniki $w$ procesie kształcenia $w$ szkole wyższej, w: Szkoła wyższa $w$ toku zmian. Diagnozy $i$ konstatacje, red. J. Kostkiewicz, A. Domagała -Kręcioch, M. J. Szymański, Impuls, Kraków 2011, s. 91-92. O wartościach konstytuujacych uniwersytet pisali: W. Humboldt, J.H. Newman, K. Twardowski, S. Hessen, W. Stróżewski, J. Bocheński, J. Brzeziński i inni.

2 S. Wlazło, Mierzenie jakości pracy szkoły, MarMar, Wrocław 1999, s. 5-8. 
nowi, iż ponad połowa zajęć dydaktycznych i pracy naukowej wymaga „bezpośredniego udziału nauczycieli akademickich lub opiekunów naukowych i doktorantów"3. Opiekun naukowy/promotor wspomaga rozwój naukowy doktoranta i ze względu na wagę tego procesu rozporządzenie Ministra Nauki i Szkolnictwa Wyższego określa, że doktorant musi mieć zapewniona "przez cały okres studiów doktoranckich opieke naukowa i wsparcie w samodzielnej pracy badawczej albo artystycznej, sprawowane przez opiekuna naukowego"4.

Jako uczestnik studiów doktoranckich obserwowałam przebieg relacji między doktorantami i ich opiekunami naukowymi, a później promotorami. Relacje te były poddawane krytyce przez niektórych uczestników studiów trzeciego stopnia, a inni nie szczędzili słów uznania dla wzajemnej współpracy. Naukowemu ogladowi postanowiłam zatem poddać relację zachodząca pomiędzy doktorantem i jego opiekunem naukowym/ promotorem $z$ perspektywy doktoranta.

\section{Założenia metodologiczne badań własnych}

Chcąc bliżej przyjrzeć się przyczynom zróżnicowania relacji doktorant-opiekun naukowy/promotor, w 2013 roku przeprowadziłam badania wśród uczestników studiów doktoranckich. Studia te w Uniwersytecie Szczecińskim realizowane sa w trybie czteroletnim. W przeprowadzonym badaniu o charakterze jakościowym udział wzięło pięciu doktorantów $z$ różnych lat studiów (trzy kobiety i dwóch mężczyzn). Taka próba badawcza jest w badaniach jakościowych ${ }^{5}$ akceptowalna, gdyż liczba osób zależy od celu ${ }^{6}$ badania. Niniejsze badania miały charakter pilotażowy, a ich celem było uzyskanie opisów relacji opiekun naukowy/promotor-dokto-

3 Artykuł 195 ust. 5 ustawy z 27 lipca 2005 r. - Prawo o szkolnictwie wyższym (DzU z 2005 r., nr 164, poz. 1365), Rozdział 3 Studia doktoranckie, http://isip.sejm.gov.pl/DetailsServlet?id=WDU20051641365 (16.08.2015).

4 Rozporzązenie Ministra Nauki i Szkolnictwa Wyższego z 24 października 2014 r. w sprawie studiów doktoranckich i stypendiów doktoranckich na podstawie art. 201 ust. 1 ustawy z 27 lipca 2005 r. - Prawo o szkolnictwie wyższym (DzU z 2012 r., poz. 572 ze zm.).

5 K. Konarzewski, Jak uprawiać badania oświatowe. Metodologia praktyczna, WSiP, Warszawa 2000, s. 77. Badania jakościowe sa zawsze indywidualizujące, najczęściej eksploracyjno-weryfikacyjne i można je przeprowadzić nawet $z$ jednym uczestnikiem badań.

6 S. Kvale, Prowadzenie wywiadów, PWN, Warszawa 2011, s. 88. 
rant, aby wyodrębnić istotne elementy tej relacji. Dobór próby był celowy, nielosowy ${ }^{7}$, ponieważ $\mathrm{w}$ badaniach jakościowych istotna jest interpretacja dokonana przez uczestnika badañ ${ }^{8}$. Zastosowałam metodę wywiadu częściowo ustrukturowanego ${ }^{9}$, w którym pytania skupiały się wokół wyodrębnionych tematów zwiąanych $z$ przebiegiem relacji: oczekiwania doktorantów, kryteria wyboru opiekuna naukowego, jego cechy cenione przez doktoranta, momenty przełomowe oraz zakończenie relacji. W artykule prezentuję wyniki badań, których źródłem sa doświadczenia ${ }^{10}$ doktorantów zwiąane $z$ relacją $z$ opiekunem naukowym/ promotorem $^{11}$.

\section{Oczekiwania - katalizator rozwoju doktoranta}

Określenie oczekiwań, również kryteriów wyboru, jak i cenionych cech promotora może dać odpowiedź na pytanie: „Czemu mnie wybierasz, co chcesz, bym zrobił?” ${ }^{2}$, ponieważ czasem podczas współpracy „mistrz atakuje, wdziera się, potrafi burzyć, aby oczyścić pole i budować na nowo"13. Budować oznacza wspólną pracę nad rozwojem naukowym doktoranta, czasem po uprzednim „zburzeniu” pewnych nabytych schematów myślenia i działania.

7 K. Konarzewski, Jak uprawiać..., s. 77, 107. Próbka celowa może być stosowana wyłącznie w badaniach indywidualizujacych.

8 T. Bauman, Poznawczy status danych jakościowych, w: Metodologiczne problemy tworzenia wiedzy $w$ pedagogice, red. J. Piekarski, D. Urbaniak-Zajacc, K.J. Szmidt, Impuls, Kraków 2011, s. 99.

9 D. Silverman, Interpretacja danych jakościowych, tłum. M.Głowacka-Grajper, J. Ostrowska, PWN, Warszawa 2012, s. 328. W transkrypcji zastosowałam następujące symbole: (.) krótka przerwa; :: przedłużenie dźwięku; znak podkreślenie dla zaakcentowanego słowa; ZNAK dla wyjątkowo głośnej wypowiedzi; () gdy nie słychać fragmentu wypowiedzi; @...@ tekst wymówiony ze śmiechem.

${ }^{10}$ M. Pryszmont-Ciesielska, Ukryty program edukacji akademickiej, Atut-Wrocławskie Wydawnictwo Oświatowe, Wrocław 2010, s. 89. Informacje o edukacji akademickiej można uzyskać z następujących źródeł: dokumenty formalne, doświadczenia podmiotów uczestniczących w edukacji, $z$ fizycznej przestrzeni.

11 Wypowiedzi doktorantów oznaczone sa litera „D” oraz przypisanym numerem kolejnej osoby: D1, D2, D3, D4, D5. W dalszej części tekstu używać będę równoważnie określenia: opiekun/promotor. Pod litera P z kolejnymi numerami zakodowane sa inne osoby, o których mówili doktoranci.

12 G. Steiner, Nauki mistrzów, Zysk i S-ka, Poznań 2007, s. 24.

13 Ibidem, s. 25. 
Oczekiwania można ująć w takie kategorie pojęciowe, jak: schematy antycypacyjne, antycypacje, standardy poznawcze, hipotezy, nastawienia, aspiracje, wzorce. Oczekiwania różnią się stopniem swego prawdopodobieństwa i obejmuja hipotezy dotyczące zajścia zdarzeń zależnych lub niezależnych od podmiotu ${ }^{14}$. Oczekiwania doktorantów w zależności od etapu pracy $z$ opiekunem/promotorem umiejscowily się $\mathrm{w}$ trzech obszarach: inspiracja, wsparcie, wiedza.

- Na wstępnym etapie studiów według uczestników badania inspiracja wiąże się $z$ rozwojem pasji oraz kontynuowaniem ścieżki rozwoju naukowego. Rozwój naukowy postrzegany jest jako podjęcie pewnego ryzyka, ponieważ nie ma pewności osiagnięcia wyznaczonego sobie celu. Motywem działania jest kontynuowanie nauki i rozwój.

Myślę, że tak naprawdę, no wiadomo, doktorat jest sporym wyzwaniem intelektualnym i czasami po prostu potrzeba jakiegoś takiego bodźca, który da inspirację, który przy nawale tak naprawdę pracy nie spowoduje, że się totalnie zniechęcimy (D3_2).

Na poczatku chciałam, żeby mnie promotor zainspirował i jakoś tak pokazał kierunki, w które mogłabym pójść. Bo ja już miałam dosyć tam obmyślony już temat, ale ugrzęzłam w martwym punkcie i nie bardzo potrafiłam z niego wyjść, i oczekiwałam, że promotor wskaże mi pewne kierunki, zainspiruje do pewnych poszukiwań i tak się stało (D2_10).

- Na etapie rozpoznania obszaru badawczego dla doktorantów ważne jest poczucie wsparcia, które oznacza dla nich pomoc określana też jako doradztwo. Pomoca dla doktorantów jest motywowanie i wyznaczanie konkretnych zadań, gdy następują momenty zniechęcenia i braku postępów w pracy.

[...] wsparcia jak gdyby w trudach ponoszenia czy w trudach będacych jak gdyby konsekwencja podjęcia studiów doktoranckich (D1_1).

[...] a wiadomo, że osoba, która już dłużej śledzi literaturę, zna się bardziej na temacie, zawsze może pomóc. [...] Tak że to na pewno pomoc tak, ale nie od podstaw [...] (D4_27).

${ }^{14}$ M. Nyczaj-Drag, Oczekiwania, w: Encyklopedia pedagogiczna XXI wieku, red. T. Pilch, Żak, Warszawa 2004, s. 751. 
- Doktoranci podkreślali, że w późniejszym etapie studiów, gdy przystępują do części empirycznej swojego projektu badawczego, oczekuja uzyskania rzeczowych, konkretnych odpowiedzi na ich pytania, wiedzy opiekuna/promotora, której sami nie posiadaja.

[...] a drugie oczekiwanie miałam takie, że oczekiwałam bardzo konkretnych, merytorycznych odpowiedzi na pytania, które mnie nurtowały $z$ doktoratem, i takie odpowiedzi też uzyskiwałam (D2_11).

[...] natomiast ten jeden procent to jest właśnie ta motywacja do pracy, czasem jakaś podpowiedź, która może nam dać promotor (D3_3).

Na tym etapie oczekuję głównie tego, co mówiłem już na początku, że będzie pilnować tego, czy praca, która wykonuję, zmierza w odpowiednim kierunku. Jeżeli nie zmierza, powie: stop i uzasadni, dlaczego to, co robię, nie jest takie, jak być powinno (D3_23-24).

Z analizy wypowiedzi wynika, że oczekiwania doktorantów są ściśle zwiazane ze stopniem zaawansowania pracy nad projektem badawczym. W poczatkowym etapie doktoranci oczekuja inspiracji jako dopingu i impulsu do innych poszukiwań, wskazania im różnych możliwości i obszarów eksploracji badawczej. Na etapie, kiedy uszczegółowiona jest tematyka badawcza, doktoranci oczekuja wsparcia w utrzymaniu motywacji do ciagłej pracy, czasem poprzez częściowe „kierowanie” ich praca. Owo kierowanie ma wyrastać $z$ afirmacji osoby, aby mogła ona wyrosnać ponad stan, $z$ jakim przyszła do opiekuna naukowego. Na etapie zaawansowanym, czyli projektowania badania i analizy wyników, doktoranci oczekuja podjęcia rzeczowej dyskusji, sprawdzania klarowności ich wywodów, bezstronności i rzeczowych uwag. Merytoryczne odpowiedzi czy podpowiedzi maja im pomagać w tym, żeby czuli się pewniej w swoich działaniach.

\section{Kryteria wyboru opiekuna/promotora przez doktoranta}

Zawsze jesteśmy wybierani lub wybieramy ${ }^{15}$, dlatego podjęcie decyzji o wyborze związane jest $z$ językiem czynu lub zaniechania ${ }^{16}$, czyli podję-

${ }^{15}$ M. Buber, Ja i Ty. Wybór pism filozoficznych, Pax, Warszawa 1992, s. 86. Por. J. Gara, Pedagogiczne implikacje filozofii dialogu, Wyd. WAM, Kraków 2008, s. 184.

${ }^{16}$ M. Buber, Ja i Ty..., s. 224. 
ciem lub brakiem podjęcia odpowiedzialności za samodzielny wybór i jego skutki. Nie zawsze szczęśliwy wybór opiekuna naukowego ${ }^{17}$ ma jednak zawsze wpływ na dalszy rozwój doktoranta. Jako kryterium wyboru lub odrzucenia może zostać przyjęty ideał osobowy Innego ${ }^{18}$, autorytet, społeczne uznanie, akceptowane cechy ${ }^{19}$, zachowania, działania, postawy ${ }^{20}$.

Wskazane przez doktorantów kryteria decydujące o wyborze i możliwości podjęcia współpracy $\mathrm{z}$ danym opiekunem naukowym nie miały wyodrębnionego jednego elementu, lecz był to zestaw, w którym jedno kryterium było decydujące, miało charakter centralny. Tym kryterium sa zainteresowania badawcze. Różne sa natomiast sposoby zdobywania wiedzy o zainteresowaniach naukowych potencjalnego opiekuna naukowego. Należą do nich: opinia innych, osobiste spotkanie, samodzielne poznawanie dorobku naukowego opiekuna. Sa też sytuacje, gdy doktoranci nie maja możliwości wyboru opiekuna. Natomiast jako kryterium odrzucenia wymieniane były cechy osobowościowe potencjalnego opiekuna naukowego.

- Opinie innych staja się decydujące, gdy doktoranci nie potrafia samodzielnie dokonać wyboru np. ze względu na wejście w nowe, nieznane środowisko naukowe. Wówczas ważnym źródłem informacji są doktoranci $z$ wyższych lat studiów, którzy znają krąg potencjalnych opiekunów naukowych. Opinia innych staje się decydująca, gdy doktorant otrzymuje informacje o zgodności tematyki własnych zainteresowań badawczych $z$ obszarem zainteresowań naukowych opiekuna.

Czasem pojawia się chęć zrzucenia odpowiedzialności za wybór na inne osoby lub system np. w postaci „kodu dopasowania” doktoranta

17 Kariera naukowa $w$ Polsce. Warunki prawne, społeczne i ekonomiczne, red. S. Waltoś, A. Rozmus, Wolters Kluwer Polska, Warszawa 2012, s. 21.

18 E. Sujak, Rozważania o ludzkim rozwoju, Znak, Kraków 1998, s. 249-154. Człowiek może przyjąć za wzór ideał osobowy innej osoby, ale także ideał osobowy można odnieść do własnej osoby w wizji przyszłości jako wzoru, do którego człowiek chce dążyć. Por. K. Olbrycht, O roli przykładu, wzoru, autorytetu i mistrza w wychowaniu osobowym, Wyd. Adam Marszałek, Toruń 2007, s. 112-113. Wzorem osobowym może zostać osoba, którą ktoś sam przyjmuje za wzór lub została ona wskazana jako obiekt do naśladowania.

${ }^{19} \mathrm{~K}$. Olbrycht, O roli..., s. 113. Uznanie kogoś za autorytet nie musi oznaczać odczuwania potrzeby naśladowania.

${ }^{20}$ Ibidem, s. 112. 
i opiekuna, który zapewniałby efektywną współpracę i skuteczność, czyli osiagnięcie założonego celu.

Jestem po innym kierunku. W momencie, kiedy zdecydowałam się na pisanie rozprawy doktorskiej na [...] Pytałam się koleżanek, które kończyły [...] u kogo ich zdaniem można byłoby pisać rozprawę i kto zajmuje się kwestiami [...]. No i tutaj padł wybór na P_2, chyba ze względu na zainteresowania badawcze także. No i taką rekomendację moich koleżanek, że jest osobą, no u której można pisać pracę także. Akurat żadna $\mathrm{z}$ nich nie pisała pod kierunkiem, natomiast profesor miała opinię osoby, u której można pisać na każdy temat (D5_67, 69, 70).

Później był ten okres właśnie przyglądania się promotorom, kiedy profesor mówiła, żebyśmy chodzili na zajęcia do różnych osób i wybrali kogoś, kto najbardziej nam odpowiada. Też nie miałam jeszcze za bardzo żadnego kodu, jak szukać kogoś, kto mi odpowiada (D5_76).

Zdanie się na opinie innych $z$ perspektywy czasu może być uznane za pozytywne, gdy relacja $z$ promotorem przebiega harmonijnie. Niekiedy pozytywna opinia innych dopełniona jest decyzja o spotkaniu z potencjalnym opiekunem. Ważna jest wówczas wyrażona zgoda na "opiekę naukowa”.

Wybór mojego promotora no to tak częściowo był przypadkiem i też nie, ponieważ wspominałem P_6, że chciałbym napisać częściowo prace $z$ [...] i P_6, pamiętajacc o tym, powiedział mi, że poznał taka pania profesor bardzo sympatyczna, ciepła, miłą osobę i po paru dniach czy po paru tygodniach zastanowiliśmy się, czy może też nie zacząłbym pisać doktoratu pod jej opieka. No to tak wyszło i jestem bardzo zadowolony $z$ tego. [...] ja zawsze mam takie założenie, że trzeba poznać osobiście osobę i zobaczyć, jak się z nia pracuje, niż po prostu bazować na tym, co inne osoby powiedzą (D4_58-59, 62).

Brak znajomości środowiska naukowego skompensowany bywa poszukiwaniem innych źródeł informacji o opiekunie naukowym. Doktoranci poza osobistym uczestnictwem w zajęciach maja możliwość zapoznania się $z$ dorobkiem kandydata na opiekuna naukowego.

[...] mimo że nie miałem wcześniej styczności z panią profesor, która wybrałem, dokonałem dość świadomie. Zapoznałem się wcześniej z literatura, $z$ publikacjami promotorki, również $z$ opiniami innych doktorantów, bo miałem kilku znajomych doktorantów już, którzy byli na wyższych latach, i na podstawie tego wybrałem właśnie promotor (D3_57). 
- Brak możliwości wyboru może wystapić ze względu na obszar zainteresowań badawczych. Podjęcie relacji z opiekunem, który jako jedyny zajmuje się daną tematyką, może zaowocować pozytywna współpraca, gdy opiera się na poczuciu zaufania. Zaufanie to rodzi się $z$ szacunku do osoby obdarzonej autorytetem ${ }^{21}$, np. moralnym.

Promotor został jakby narzucony, natomiast bardzo pozytywnie i bardzo się cieszę $z$ wyboru akurat tutaj mojego opiekuna, promotora mojej pracy (D1_32).

Ta moja sytuacja jest o tyle specyficzna, że ja nie, tak jakby $z$ góry było oczywiste, kto będzie moim promotorem [...] i tutaj właściwie nie było wyboru. Szczególnie, że kwalifikacje pasowały do tematu, który ja sobie wybrałam [...] to była właściwie jedyna osoba, która miała takie kwalifikacje, żeby być moim promotorem, zajmowała się tą tematyką i wszystko sprzyjało, bo mieliśmy bezpośredni kontakt [...], często się widywaliśmy, więc to było oczywiste, że wszystko pasuje i gra (D2_44-46).

- Za kryterium odrzucenia może zostać uznane nieakceptowanie osobowych cech opiekuna/promotora.

[...] tutaj właśnie jako przykład, dlaczego można np. nie wybrać promotora, bo powód jest w zasadzie bardzo błahy. Profesor sobie jakieś takie dowcipy na temat kobiet i relacji ze studentkami, takie to było oczywiście żartobliwe, ale coś mnie wtedy, pamiętam, nie przypasowało. [...] Później okazało się, że osoby, które tam lokują, z powodzeniem piszą. Więc jakby była to płytka ocena, ale już ja w zasadzie byłam zdecydowana (D5_78).

Podsumowując, można stwierdzić, że doktoranci podejmuja świadomie działania, aby zwiększyć swoje szanse na osiągnięcie założonego celu. W badanej grupie żaden $z$ doktorantów nie okazał bezradności ani zupełnej bierności i nie pozostawił kwestii wyboru opiekuna losowi.

Przekonanie, że ma się wpływ na zdarzenia, świadczy o poczuciu własnego sprawstwa w działaniu, dlatego inicjatorzy zdarzeń mają więk-

${ }^{21}$ L. Witkowski, Wyzwania autorytetu $w$ praktyce społecznej $i$ kulturze symbolicznej, Impuls, Kraków 2009, s. 64. Autorytet moralny występuje w imieniu wartości. A zogniskowanie na aspektach moralnych stwarza okazję do zbudowania własnej indywidualności wrażliwej na otaczający świat i istniejące w nim wartości. 
sze szanse na indywidualny rozwój ${ }^{22}$. Bierność i bezradność prowadzi natomiast do tego, że osoba uznaje, iż wszystko zależy od innych, i powodzenie planów składa w ręce przypadku, nie wykazując aktywności ${ }^{23}$.

\section{Cechy opiekuna naukowego/promotora}

Katalizatorem rozwoju doktoranta staje się podczas studiów opiekun naukowy/promotor. Oznacza to włączenie się człowieka dojrzałego i doświadczonego w danej dziedzinie w proces rozwoju człowieka mniej doświadczonego. Wśród wymienianych przez doktorantów cech promotora wyodrębnić można cechy wyróżniające, cechy cenione oraz cechy wykluczające. Promotor dla niektórych doktorantów staje się mistrzem, dlatego jego cechy przypisać można do takich kategorii promotorów opisywanych przez doktorantów, jak: idealny mistrz, niedościgniony wzór, niedoskonały wzór.

- Cechy wyróżniające wybranego opiekuna/promotora lokowane sa w obszarze kompetencji. Istotne sa zatem wiedza, umiejętności i postawa oraz wykonywanie swoich czynności z pasją.

Mistrza mam [...] i nie wiem, czy wie, że jest moim mistrzem, ale jest nim. Chociaż promotor też $\mathrm{w}$ pewnym sensie jest, to jest jednak praca normalniejsza, niż ja mam tę ze swoim mistrzem relację (D2_97).

Jeszcze mistrz, no może taka osoba, która zawsze ma odpowiedź, może doradzić tak od razu, to można też uznać, że to jest mistrz, osoba, która się zna na sprawie, nie. A nawet jak się nie zna, to wie, gdzie znaleźć odpowiedź, zasugeruje, gdzie poszukać informacji (D4_133).

Katarzyna Olbrycht pisze, że „rozwój osoby, będąc dążeniem do pełnego człowieczeństwa, jest w swej istocie dażeniem do doskonałości, doskonałości rozumianej osobowo"24. Doktoranci maja pewne wyobrażenie o modelowym promotorze, $z$ którym chcieliby podjać pracę, i w zależności od swoich oczekiwań dokonuja wyboru opie-

${ }^{22}$ W. Łukaszewski, Szanse rozwoju osobowości, Książka i Wiedza, Warszawa 1984, s. $112-123$.
23 Ibidem.
${ }^{24}$ K. Olbrycht, O roli..., s. 127. 
kuna naukowego, który najczęściej zostaje ich promotorem i czasem uznawany jest za mistrza. Według doktorantów idealny mistrz ${ }^{25}$ oprócz posiadania szerokiej wiedzy potrafi nią zainteresować, jest osoba empatyczna, wspierająca, pomagajaca w rozwoju i potrafiąca przyjać informacje od swojego doktoranta, a nawet krytykę. Jest także osoba refleksyjną, która analizuje współpracę $z$ uczniem oraz swoje postępowanie i nie ustaje $\mathrm{w}$ dążeniu do dalszego własnego rozwoju.

Mistrzem na pewno będzie taka osoba, która oprócz ogromnej wiedzy posiada również, czy jest dla mnie autorytetem, tak jak mówiłam wcześniej, moralnym i myślę, że tutaj pani profesor rzeczywiście jest dla mnie takim autorytetem również moralnym i dlatego uważam, że jest mistrzem. [...] Mistrz idealny to na pewno taka osoba, która oprócz ogromnej wiedzy, która posiada, jest osoba taka empatyczna, też tak jak gdyby właśnie wspierająca, pomagająca w rozwoju te inne osoby tak, ale to też taka osoba, która jak gdyby potrafi przyjąc też jakieś, jakąs informacje jakby $z$ naszej strony czy jakąs nawet krytykę, czy niezgadzanie się $z$ jakąś kwestia tak. [...] ciagle możemy dążyć do tego, żeby być doskonałymi, ale w gruncie rzeczy pewnie nigdy nikt tej doskonałości nie osiaga. [...] dla mnie osoba mistrza jest to osoba doskonała, ale zdaję sobie sprawę $z$ tego, że każda osoba się rozwija $\mathbf{i}$ ten mistrz też się rozwija (D1_90-95).

Myślę, że nie ma doskonałych osób, i myślę, że świadomość, że warto dążyć do doskonałości, wystarczy. I moja mistrzyni ma taka świadomość, że warto dążyć do doskonałości, i dąży do niej. Natomiast ja nie uważam, że istnieja ludzie doskonali, i nie oczekuję od niej, żeby () doskonały pod każdym względem (D2_106).

W opinii doktorantów cechy konieczne, a zarazem wystarczające do tego, aby być uznanym za mistrza, to poza wiedza jest również posiadanie pasji i okazywanie zaangażowania w relacjach, otwartość i umiejętność dyskusji. Według doktorantów mistrz inspiruje i zachęca do doskonalenia się.

Myślę, że nie ma takiego zestawu cech, który pozwoliłby stworzyć taki wizerunek idealnego mistrza, bo to też tak naprawdę zależy

${ }^{25}$ Por. ideał współczesnego uczonego w: A. Żywczok, Aksjologia odkrycia naukowego studium rozwoju i wychowania osobowości naukowych, Wyd. Adam Marszałek, Toruń 2009, s. $75-77$. 
też od naszych indywidualnych preferencji, ale takie główne cechy to właśnie, według mnie, szczególnie otwartość, i na drugiego człowieka, i na jego idee; tak (D3_122).

- Cechy cenione. Każdy doktorant i każdy opiekun naukowy/promotor charakteryzuja się określonymi cechami, a spotkanie i nawiązanie relacji zawsze $\mathrm{w}$ jakiś sposób dokonuje zmiany w uczestnikach spotkania, ponieważ jak pisze Krzysztof Wieczorek, mistrz oddziałuje na ucznia także swoją osobowością ${ }^{26}$.

Niektórzy doktoranci na aktualnym etapie studiowania uznaja mistrza w innej osobie niż ich opiekun/promotor. W ich ocenie cenione cechy, które dostrzegają u swoich opiekunów/promotorów, to: wiedza, otwartość, umiejętność dyskusji, poczucie humoru, umiejętność pomagania i ciepło.

Obrona przed uznaniem drugiej osoby za mistrza i próba odbrazowienia jej może się dokonywać, gdy doktorant uważa swojego opiekuna/ promotora za niedościgniony wzór, któremu nigdy nie dorówna. Chęć nawiązania relacji współwystępuje $z$ tworzeniem dystansu wobec nieosiagalnego wzoru:

[...] Natomiast o mistrzach mówi się mistrzowie. No to na początku mnie śmieszyło, bo to tak brzmi z urzędu, ale wydaje mi się, że pewien romantyzm taki, nawet właśnie tej nomenklatury po pewnym czasie mi się udzielił tak. [...] Natomiast właśnie okazało się, że sa pewne nisze, [...] gdzie można $z$ tymi osobami wejść $w$ takie autentyczne relacje życzliwości, pomocy, tego mistrzostwa właśnie, no też, tak. [...] Więc wydaje mi się, że znalezienie kogoś, kto miałby być dla ciebie tym przewodnikiem i mistrzem, jest jakąś taką fantastyczna rzeczą [...] (D5_163-164, 166-169).

Czasem chęć bycia podobnym do mistrza pobudza mechanizm naśladownictwa. Niektórzy jednak rozpoczynaja świadomie naśladować opiekuna/promotora, aby czuć przynależność według nich do wyróżnionej zbiorowości ${ }^{27}$. Pojawia się jednak tutaj problem gotowo-

${ }^{26} \mathrm{~K}$. Wieczorek, Mistrzom podobni, lecz wierni sobie. O autonomii podmiotu relacji mistrz - uczeń, w: Z tęsknoty za mistrzem, red. J. Kurek i K. Maliszewski,Miejski Dom Kultury Batory w Chorzowie, Chorzów 2007, s. 23.

${ }^{27}$ L. Witkowski, Historie autorytetu wobec kultury i edukacji, Impuls, Kraków 2011, s. 736-737. Budowanie autorytetu pedagogicznego na profilu dominującego uwzniośle- 
ści do bycia doktorantem i dobrowolnego kształtowania siebie pod kierunkiem Innego lub wzorowania się $z$ wykorzystaniem wskazówek Innego, którym może być opiekun/promotor uznawany za mistrza ${ }^{28}$.

Znaczy, nie mówię tutaj, że trzeba jak gdyby stać się taką osoba jak nasz mistrz tak, tylko że powinniśmy jak gdyby dą̇yć do takiego rozwoju, naszego rozwoju, który będzie rozwojem dobrym, pozytywnym tak, i tak jak mówiłam wcześniej, że jeśli uważam, że profesor jest moim mistrzem, i widzę, że rzeczywiście ten jego rozwój jest takim rozwojem dobrym, no to dlaczego mam uważać, że naśladownictwo jest coś złego, jeśli rzeczywiście mój rozwój będzie odbywał się w tym kierunku pozytywnym (D1_362-363).

Tak, ale uważam, że nie powinno się naśladować promotora. Może nie tak, nie we wszystkim. Sa pewne aspekty, tak jak mamy np. właśnie u promotora jakąs typu właśnie otwartość umysłu, no to tutaj te cechy sa godne naśladowania. Natomiast jeżeli chcielibyśmy naśladować naszego promotora, piszac np., nie wiem, teksty w podobnym stylu, bo wydaje nam się, że ten styl jest najlepszy $z$ możliwych, no to uważam, że takie naśladowanie jest bardzo złe, ponieważ tak naprawdę to, co robimy, traci wartość, tak. To już nie jest nasze, tylko to jest pozorowanie na jakiś wzór [...] (D3_366-368).

Doktoranci wskazują, że w pewnych aspektach naśladownictwo jest pozytywnym procesem, jeśli nie ogranicza się do bycia „kopia mistrza” i „podkładania siebie pod obrany wzór”. Naśladownictwo nie może bowiem być ślepym kopiowaniem stylu swojego promotora, gdyż wtedy następuje utrata własnego stylu.

- Cechy wykluczajace. W opinii doktorantów w obszarze wyłączonym $z$ mistrzostwa lokowana jest osoba, która sama uważa siebie za doskonała, osoba zapatrzona w siebie, osoba stwarzajaca dystans między „naukowcami a nienaukowcami”, osoba o znacząco innym temperamencie niż doktorant. Bycie mistrzem wyklucza brak kompetencji w dziedzinie, którą uprawia opiekun/promotor, i jego niski poziom moralny.

nia jednostki na dystans oznacza postrzeganie $z$ perspektywy funkcji wywoływanego efektu i oparte jest na profilu przynależności do wyróżnionej zbiorowości.

${ }^{28}$ K. Olbrycht, O roli..., s. 37. 
Ja bardzo nie lubię w środowisku naukowym takiego zadęcia, wywyższania się, pokazywania swojej przewagi nad innymi, bo to nie o to chodzi. [...] Więc jakbym miała powiedzieć, gdzie jest ta granica, że ktoś już jest dla mnie mistrzem, no to chyba to jest ta granica wiedzy, że to jest jednak osoba wszechstronna, która doskonale zna się na swojej działce i doskonale zna się na wszystkim, co się z jej działką wiąże. Więc nie tylko wąsko w tym jednym, ale zna kontekst, jest to na pewno to kryterium wiedzy i kryteria takiego właśnie inspirowania, prowadzenia innych osób, że to jest osoba, która nie zniechẹca do nauki, nie zniechęca do poszukiwania, ale właśnie zacheca i ma taka postawę życiowa nauczycielska, wychowawcza, że motywuje osoby aspirujace do życia naukowego, żeby właśnie rozwijały się w tym zakresie. Więc myślę, że to sa takie dwa podstawowe elementy. Nie powiedziałabym, że jest ktoś mistrzem, choćby był najmadrzejszy i miał przepotężna wiedzę, ale gdyby był właśnie taka osobą bardzo zapatrzoną w siebie, stwarzajaca dystans między naukowcami a nienaukowcami, nie powiedziałabym, że to może być mistrz dla kogoś. [...] Myślę, że nie każdy może zostać mistrzem (D2_108, 111, 113, 114).

Niedoskonały wzór może budzić szacunek, ponieważ dostrzeganie drobnych niedoskonałości daje doktorantom poczucie, że moga się zbliżyć do opiekuna/promotora np. poprzez zgłębianie tej samej dziedziny wiedzy.

Nie, zdecydowanie nie powinien być doskonały, $z$ tego względu, że po pierwsze, nie uważam, że jakiś naukowiec może być doskonały, bo tak naprawdę rzeczywistość, szczególnie tutaj w naukach społecznych, w naukach humanistycznych, ciagle się zmienia i trzeba być ciagle na bieżąco, żeby prezentować w ogóle jakiś tam dość wysoki poziom wie$\mathrm{dzy}$, bo na pewno nie idealny, a poza tym idealny promotor bylby źródłem pewnie@kompleksów@dla doktoranta. [...] Bo tak naprawdę większość ludzi uważa, że nie może być idealna, w związku z czym idealny promotor byłby niedoścignionym wzorem do naśladowania, a tak wiemy, że możemy może nie tyle doścignać kiedyś tego promotora, ale jednak w jakiś sposób się do niego zbliżyć dzięki temu, że też zgłębiamy jakąś tam dziedzinę czy gałąź nauki (D3_86-87).

No to wiadomo, nikt nie jest doskonały, nie, ale na pewno powinien być taką osobą, która budzi szacunek [...] (D4_88).

Reasumując, należy podkreślić, że utożsamianie siebie z promotorem może prowadzić do chęci upodobnienia się do obranego idealnego 
wzoru ${ }^{29}$ poprzez proces naśladownictwa ${ }^{30}$, w którym zanika rozdzielenie Ja i Ty ${ }^{31}$. Promotor może też być brany za przykład, wzór, autorytet, postrzegany jako doradca w rozwoju, jako mistrz lub mentor ${ }^{32}$, który aktywnie lub biernie wspomaga rozwój. Jako podsumowanie zacytuję tutaj wypowiedź jednego $z$ doktorantów:

Więc wydaje mi się, że każdy ma szanse zostać mistrzem, może nie dla tego samego audytorium i nie w tej samej dziedzinie (D5_150).

\section{Możliwości i bariery rozwoju doktoranta}

Rozwój doktoranta odbywa się dzięki uświadamianiu sobie własnego potencjału i korzystaniu $z$ możliwości, jakie daje współpraca $z$ opiekunem/promotorem. Relacja może być przeplatana różnymi momentami, które moga stać się przełomowe dla dalszego jej przebiegu, jak również dla rozwoju jej uczestników.

Doktoranci określaja swój stosunek do biegu zdarzeń, których sa uczestnikami poprzez podjęcie studiów doktoranckich i podjęcie relacji $\mathrm{z}$ opiekunem/promotorem, a także poprzez uczestnictwo w różnych zdarzeniach, gdzie dwie strony oddziałuja na siebie ${ }^{33}$. Doktoranci podkreślaja znaczenie swobody w swoich działaniach naukowych, ale także zauważaja, że swoboda może stanowić ryzyko dla efektów ich pracy ${ }^{34}$. Wolność zatem może stwarzać szansę rozwoju we własnym tempie lub stanowić zagrożenie, gdy zabraknie odpowiedzialności za realizację podjętych celów i ukończenie „zadania” w określonym czasie. $Z$ opisów relacji dokto-

${ }^{29}$ Ibidem, s. 57. Zob. dążenie do przyjętego ideału siebie.

${ }^{30}$ Ibidem, s. 56. Zob. naśladownictwo to wierne kopiowanie zewnętrznych zachowań.

${ }^{31}$ Ibidem, s. 62-64. Autorytet zakazu stwarza sytuację wrogości oraz niechęci i może prowadzić do zniewolenia. Autorytet racjonalny oznacza udzielanie pomocy i pozytywny wpływ na rozwój.

${ }^{32}$ Z. Pietrasiński, Rozwój człowieka dorosłego, Wiedza Powszechna, Warszawa 1990, s. 96. Posiadanie mentora sprzyja realizacji fundamentalnego zadania rozwojowego sprecyzowanie i osiagnięcie celu nadrzędnego - marzenia życia lub wizji stanu idealnego.

${ }^{33}$ W. Łukaszewski, Szanse rozwoju..., s. 112-113.

${ }^{34}$ J. Kozielecki, Koniec wieku nieodpowiedzialności, Wyd. Jacek Santorski \& CO, Warszawa 1995, s. 50-51. Wolność i odpowiedzialność powinny współwystępować i warunkować się, ponieważ „nie ma wolności bez odpowiedzialności”. 
rantów z opiekunem/promotorem wyodrębnić można zauważane przez doktorantów: możliwości, bariery oraz bunt, które mogą wspomagać lub hamować rozwój.

- Możliwości. Niektórzy doktoranci bez „nacisku” dokonanego przez opiekuna/promotora nie podejmowaliby wyzwań, które pomagaja $\mathrm{w}$ rozwoju. Inni natomiast cenia pewien element swobody pozwalający na podejmowanie eksperymentów. Zewnętrzne uwarunkowania rozwoju w tym przypadku obejmują możliwości, których źródłem jest promotor „nadajacy sens” pracy doktoranta poprzez okazywanie zainteresowania, co motywuje do dalszych poszukiwań ${ }^{35}$. Wewnętrzne uwarunkowania rozwoju obejmuja własne poczucie sprawstwa i wpływu na zdarzenia. Świadomość obecności „bezpiecznego brzegu" u boku promotora daje poczucie bezpieczeństwa naukowego z możliwością rozwoju poprzez szukanie nowych dróg. Jest to poczucie wolności ze świadomościa, że blisko jest opiekun/promotor.

No właśnie wydaje mi się, że głównie przykładem jakby osoby, która sama, no moim zdaniem, jest takim człowiekiem naukowego sukcesu, tak. Bo jest, wydaje mi się, że spokojnie mogę powiedzieć, że chciałabym osiagnąć ten poziom i chciałabym taka być. [...] udział w grantach, w projektach to jest to, do czego bez mobilizacji bym się na pewno nie zgłasza (D5_222, 224).

Więc ja mam ze swoim promotorem poczucie wolności i swobody. Wiem, że każde działanie jest moje i że ostatecznie to przecież ja za to odpowiadam, ale jest ten bezpieczny brzeg, do którego ja się moge złapać i zapytać o wszystko, i w każdym temacie skonsultować. Tak że myślę, że to jest taki element rozwoju, że ja mam zapewnione poczucie bezpieczeństwa naukowego, które pozwala mi się rozwijać i iść dalej, i szukać nowych dróg dobrych dla siebie, dla swojego doktoratu (D2_217-218).

- Bariera dla doktorantów jest tworzenie szkodliwego dystansu, gdy promotor traktuje innych przedmiotowo i stwarza dystans między „naukowcami i nienaukowcami". Barierą bywa też różnie postrzegane przez każdą ze stron optymalne tempo pracy. Doktoranci zauważa-

${ }^{35}$ A. Żywczok, Aksjologia odkrycia..., s. 192. Odwaga negacji spojrzenia w pustkę jest łatwiejsza, gdy doktorant ma poczucie bezpieczeństwa naukowego u boku opiekuna/ promotora. 
ją także bariery w postaci własnej nadmiernej drobiazgowości, przez którą traca dużo czasu. Kolejną barierą bywa nieumiejętność korzystania $z$ przyznanej wolności, która w połączeniu $z$ brakiem dyscypliny stanowi dla doktoranta hamulec w rozwoju naukowym, dlatego niektórzy oczekuja prowadzenia krok po kroku. Dla jednych zatem wolność jest motorem do działania, dla innych przeszkodą w działaniu.

Największym niebezpieczeństwem może być to, gdy doktorant uważa, że jego promotor jest tak naprawdę wyrocznia, nie mówię tutaj o swoim przypadku, na szczęście. Może to po prostu zabić wszelką kreatywność, może to też zabić w człowieku chęć pisania tego doktoratu, bo to ma być coś naszego, coś własnego, w zwiazku $z$ tym tutaj to jest chyba największe niebezpieczeństwo, gdy w promotorze widzimy tak naprawdę ostateczna instancję, że tak powiem, co do naszej pracy (D3_415-416).

- Bunt ${ }^{36}$ może być aktem twórczego namysłu i chęci podjęcia dialo$\mathrm{gu}^{37}$. Rezygnacja $z$ buntu poprzez tłumienie wyrażania sprzeciwu nie pomaga w podejmowaniu dialogu i może hamować rozwój, dlatego tak ważna jest osoba opiekuna/promotora ${ }^{38}$, który potrafi burzyć zastane i utarte sposoby działania, aby rozbudzić kreatywność doktoranta.

No, jeśli dla mnie jest ktoś mistrzem, takim, o którym mówiłam wcześniej, no to nie będę się wobec niego buntowała, bo mogę się buntować wobec kogoś, kto nie jest dla mnie mistrzem. Natomiast tutaj no jakby zupełnie nie jest to, jakby zgodne tak, bo jeśli przyjmuję kogoś za mistrza, to znaczy, że rzeczywiście jest dla mnie mistrzem i się wobec niego nie buntuję, mogę się buntować przeciwko innemu nauczycielowi, który traktuje mnie przedmiotowo i nie prowadzi ze mna dialogu, to tak, ale nie w takiej sytuacji (D1_439-442).

Nie wyobrażam sobie takiej sytuacji, żeby mój promotor narzucił mi, że ja mam pisać pracę empiryczna, a nie teoretyczna, bo właściwie

${ }^{36}$ G. Steiner, Nauki..., s. 33. „Nerwem nauczania jest argumentacja. Nauczyciel przyciaga uwagę, przekonuje, chce uzyskać [...] twórczy sprzeciw".

${ }^{37}$ Z. Nęcki, Komunikacja międzyludzka, Wydawnictwo Profesjonalnej Szkoły Biznesu, Kraków 1996, s. 275. „Okresowe wyrażanie gniewu czy niechęci nie jest destrukcyjne, może pogłębiać wzajemne zrozumienie, ale stała negatywna komunikacja jest patologiczna, wymaga interwencji”.

${ }^{38}$ U. Ostrowska, Relacje interpersonalne jako problem edukacyjny, w: Aksjologiczneaspekty relacji interpersonalnych $w$ edukacji, red. U. Ostrowska, Impuls, Kraków 2002, s. 50-51. Zawiłość relacji interpersonalnych w edukacji wymaga odpowiednio ukonstytuowanych osób biorących w niej udział. 
dlaczego? No to w takiej sytuacji to jest kwestia, no nie wiem, kto się lepiej w czym czuje. Więc w takiej sytuacji, myślę, że jak najbardziej powinniśmy mieć wybór, natomiast zupełnie inna jest sprawa w kwestii rozstrzygnięć. Bo jeśli mój promotor upiera się, że lepsza będzie do moich badań ankieta, a nie wywiad, no to to jest kwestia rozstrzygnięcia merytorycznego, on się pewnie lepiej na tym zna niż ja, więc w takiej sytuacji pewnie trzeba się zdać na promotora. Ale to jest właśnie kwestia takiej osobowej, podmiotowej relacji, że my traktujemy się, ja wiem oczywiście mniej od mojego promotora, ale traktujemy się w taki sposób podmiotowy, jako równe osoby [...] (D2_447-449).

To znaczy uważam, że doktorant oczywiście ma prawo, ale zazwyczaj $\mathbf{z}$ tego prawa rezygnuje, ponieważ jest to tak naprawdę bardzo trudne $z$ punktu widzenia doktoranta, bo nigdy nie wie, jak zareaguje ta druga strona, chyba żeby swojego promotora już znał na wylot i obawia się też konsekwencji tego sprzeciwu czasami, tak (D3_450).

Twórczy bunt według doktorantów oznacza podjęcie „konstruktywnego sporu", który przez Roberta Kwaśnicę opisywany jest też jako dyskusja $z$ poszanowaniem wspólnego stanowiska, gdzie celem jest jakieś uzgodnienie poglądów ${ }^{39}$.

Może w ten sposób, na pewno jakbym czuł, że mam rację, no to na pewno, to jakbym się z czymś bardzo nie zgadzal, to bym próbował udowodnić swoja rację, nie, czyli nie tak pochopnie działajac, ale np. bym zebrał piśmiennictwo na temat, zobaczył, jak inni postępuja, i wtedy przedstawił, i się zapytał, czy mógłbym w podobny sposób zrobić, nie. Tak że no ja zawsze przyjmuję taką taktykę [...] (D4_458).

Tutaj myślę, że jeżeli chodzi o kwestie właśnie doktoratu, to obie strony maja możliwość spojrzenia na problem $z$ innej perspektywy. Dzięki temu można znaleźć, można odkryć jakiś ciekawy problem, tak, jakieś pole do dyskusji, można zmienić też pogląd na jakąś sprawę ważna lub mniej ważna i to jest tak naprawdę inspirujące intelektualnie, bo tak naprawdę stwarza nieskończenie wiele możliwości, tak. Poza tym, jeśli chodzi o promotora, to tak jak już wcześniej mówiłem, $\mathrm{w}$ pewnym sensie, w pewnym stopniu on jest zawsze wzorem, bo jego sugestie są cenne, tak, jego wkład w tę pracę, zresztą wkład promotora

${ }^{39}$ R. Kwaśnica, Ku dialogowi $w$ pedagogice, w: Pedagogika alternatywna. Dylematy teorii, red. B. Śliwerski, Impuls, Kraków 2000, s. 59-60; F. Znaniecki, Relacje społeczne $i$ role społeczne. Niedokończona socjologia systematyczna, PWN, Warszawa 2011, s. 120. Konstruktywny spór należy odróżnić od konfliktów, które zakłócaja normatywnie regulowany przebieg relacji. 
w pracę zawsze będzie widać, zawsze jakiś ślad promotora w tym pozostanie i to jest dobre chyba i dla doktoranta, i dla promotora, tak mi się wydaje, bo promotor ma też pewnie swego rodzaju satysfakcję $z$ tego, że pomógł powstać jakiejś konkretnej pracy, tak (D3_460-464).

Podsumowujac, można podkreślić, że dla doktoranta ważny jest rozwój naukowy, który przebiega pod kierunkiem opiekuna/promotora czasem uznawanego przez doktoranta za mistrza dostarczajacego pozytywnych wzorów ${ }^{40}$. O możliwości wykorzystania szansy na rozwój decyduje m.in. umiejętne korzystanie $z$ danej wolności. Na drodze rozwoju moga pojawić się pewne bariery, które należy pokonać, aby wykorzystać możliwości, jakie niesie ze soba relacja $z$ doświadczonym pracownikiem naukowym - promotorem. Barierę w rozwoju stanowić może bierność oraz zaniechanie zadawania pytań ${ }^{41}$.

\section{Zenit współpracy}

Zakończenie relacji może nastapić na różnych etapach wzajemnej współpracy, zarówno w jej początkowej fazie, jak i po osiagnięciu założonych celów ${ }^{42}$. Etapy buntu i twórczej argumentacji maja przygotować doktoranta do późniejszej samodzielności, ponieważ jak pisał George Steiner, „rzetelnie nauczać to budzić w uczniu watpliwości, ćwiczyć go w niezgodzie. Przygotowywać go do odejścia. [...] Prawdziwy mistrz zostaje w końcu sam”"3. Promotor „oddaje” zatem swojego doktoranta zarówno szerszej społeczności, jak i węższemu gronu specjalistów w swojej dziedzinie.

Po przeprowadzeniu wywiadów opracowałam wstępny model kształtowania się relacji doktorant-opiekun/promotor. Poszczególne etapy relacji zachodzą na siebie, a zakończenie relacji może nastapić na każdym z etapów, jednak już rozpoczęcie relacji zakłada dążenie do osiagnięcia określonego celu, który zamyka pewien etap (na rysunku linia przerywania w prostoka-

${ }^{40}$ K. Wieczorek, Mistrzom podobni..., s. 23. „Mistrz to ktoś, kto swoim życiem i postępowaniem dostarcza mi pozytywnych wzorów, a przez to wywiera istotny wpływ na kierunki mojego rozwoju osobowego".

${ }^{41}$ E. Sujak, Rozważania..., s. 239.

42 G. Steiner, Nauki..., s. 61. „Rozłączanie jest słuszne i konieczne. [...] Teraz uczeń musi zwrócić się ku wyższej nauce".

43 Ibidem, s. 111. 
cie). Później relacja może być kontynuowana, ale pewien etap współpracy zostaje zakończony wraz z zakończeniem toku studiów doktoranckich.

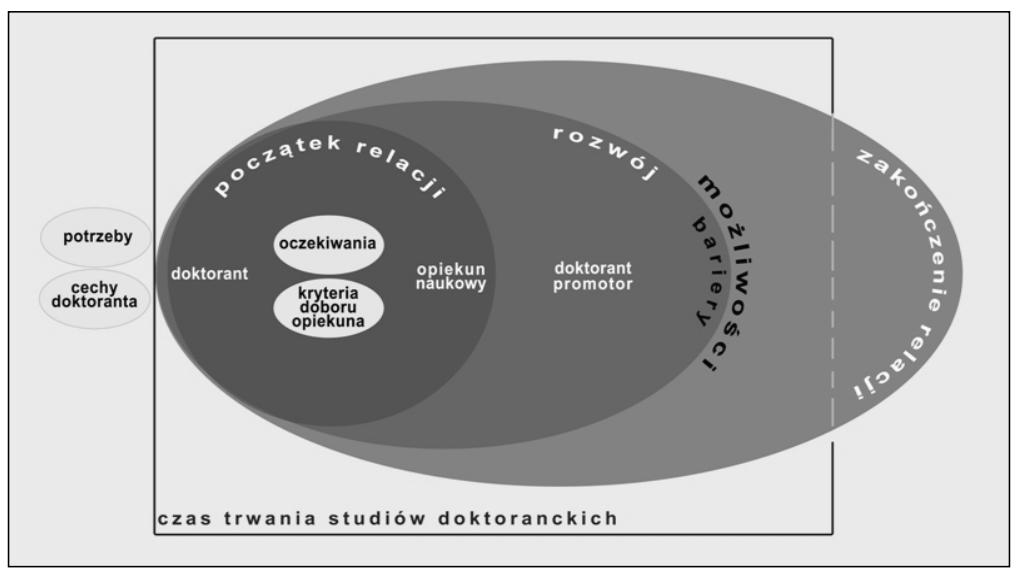

Rys. 1. Ślad relacji. Model kształtowania się obszarów relacji doktorant-promotor Źródło: opracowanie własne. Relacja może zakończyć się w toku studiów lub w późniejszym czasie.

\section{Podsumowanie}

Zbigniew Kwieciński pisał o wyzwaniach postnowoczesności, potrzebie odzyskania podmiotowości i tożsamości, zrozumienia kreowanego świata, odnalezienia swojego miejsca w społeczeństwie ${ }^{44}$. Świat doktoranta podczas studiów skupiony jest na rozwoju dzięki wykorzystaniu danego czasu i warunków, które stwarza szkoła wyższa poprzez uruchomienie studiów trzeciego stopnia, dając tym samym możliwość nawiązania relacji doktorantopiekun/promotor. Oczekiwania, cechy osobowe, sposób budowania relacji i pokonywania barier oraz wykorzystania możliwości muszą się dopełniać, aby relacja dawała możliwość uzyskania zaplanowanych efektów rozwoju. Doktoranci oczekują odpowiedzi na nurtujące ich pytania, warto jednak podkreślić, że postawa dialogiczna oznacza dwustronność, m.in. umiejętność stawiania pytań i dawania odpowiedzi, aby był to dialog prawdziwy ${ }^{45}$.

${ }^{44}$ Z. Kwieciński, Tropy - ślady - próby. Studia $i$ szkice z pedagogiki pogranicza, Edytor, Poznań-Olsztyn 2000, s. 32.

${ }^{45}$ M. Buber, Ja i Ty..., s. 226. 
Istotne jest też ponoszenie odpowiedzialności w określonych sytuacjach $i$ konkretnych działaniach ${ }^{46}$. W relacji doktoranta $z$ opiekunem naukowym/ promotorem ważna jest więź między nimi, gdyż jak napisał George Steiner: "Więź między mistrzem i uczniem staje się osią całej podróży”47. Relacja doktoranta $z$ opiekunem/promotorem może stać się relacją mistrz-uczeń, gdzie „to starannie wyliczone diminuendo odmierza malejącą zależność od mistrza”48 i umożliwia „niestopienie się” doktoranta z promotorem.

Slowa kluczowe: uniwersytet, studia doktoranckie, relacja

\title{
THE UNIVERSITY AS A AREA OF COOPERATION OF THE ACADEMIC SUPERVISOR/PROMOTER AND PHD STUDENT
}

\begin{abstract}
Summary
Many universities offer the $\mathrm{PhD}$ studies especially for persons appreciating scientific, pedagogic-educational and civic values. Targeting the values influences the research thoroughness, type of undertaken relation and sense of responsibility for the common good. The relation between the academic supervisor/promoter and $\mathrm{PhD}$ student bases on the personal and seminar meetings. The law of the high education regulates the type of courses and underling the necessity of the direct scientific tutoring and supporting in autonomous researching. Some of the $\mathrm{PhD}$ students criticises the relation of supervisor/promoter and $\mathrm{PhD}$ student. The another $\mathrm{PhD}$ students praise this relation. I have researched this relation from the PhD student's view point. I have focused my attention on student's expectations, choosing criteria of the academic supervisor/promoter, his/her characteristics, breakthrough moments and the ending of the relation.
\end{abstract}

Keywords: university, $\mathrm{PhD}$ studies, relation

Translated by Michał Kulik

${ }^{46}$ E. Mounier, Co to jest personalizm oraz wybór innych prac, tłum. A. Krasiński, D. Eska, A. Turowiczowa, znak, Kraków 1960, s. 171.

47 G. Steiner, Nauki..., s. 57.

48 Ibidem. 


\section{PRAKTYKI}





\section{Hussein Bougsiaa}

Uniwersytet Gdański

\section{Mobile LearningEnhancement in Higher Education}

Contemporary society ${ }^{1}$ is characterized by fragmentation, individualization and mobility in which cultural practices related to consumption, information and knowledge production ${ }^{2}$, organization and distribution are "chunked", structured and connected in very different ways from lectures, webs and books ${ }^{3}$. Knowledge is not just "consumed" but individually transformed in many meaningful ways. Mobile technologies are increasingly embedded in the life-worlds of people. They allow people to deal with such fragmented and personally transformed knowledge and information. Because of the degree of integration with everyday life mobile technologies are considered as very important cultural resources which embody the social values and which are shaped by social structures, cultural practices and people's agency ${ }^{4}$. Mobile technologies are also important from an educational perspective as the convergent tools for meaning making, for engaging with and for mediating the world around people as well as communication with it. Their increasing portability, functional convergence and connectivity have a great potential for social interactivity, ubiquitous information retrieval, processing and exchange as well as context sensitivity and location awareness ${ }^{5}$. Additionally, it has to be considered an increasing level of expertise of

1 This article reports on a piece of research carried out as part of the project M-rodzicei m-dzieci: bezprzewodowa socjalizacja i uczenie się w kulturze cyfrowej (M-parents and m-children: wireless socialization and learning in digital culture), NCN 2013/09/B/ HS6/03091.

2 A. Elliott, J. Urry, Mobile Lives, Routledge, London-New York 2010.

3 W. Traxler, Education and the Impact of Mobiles and Mobility: An Introduction to Mobiles in our Societies, in: Ben Bachmair, Medienbildung in neuenKulturraumen: Die deutchsprachige und britischeDiskussion, VS Verlang fur Sozialwissenschaften, Wiesbaden 2010, p. 101-111.

4 Ibidem, p. 102.

5 J. Seipold, N. Pachler, Evaluation Mobile Learning Practice, "MedienPadagogik" 2011, no. 19 , p. 2 . 
young people in the use of mobile technologies and their participation in complex networking activities and communication.

\section{Net generation?}

New generation of students grow up in a world that is saturated with media and technology of many kinds. They are surrounded by technologically mediated images, words and sounds; and they are actively using technology in order to learn, to entertain themselves, to communicate, and to represent their own perspectives and concerns. Their relationships with the family and the peer group are increasingly mediated through electronic and digital technologies; and indeed, many of them are using these technologies to form new relationships with people whom they may never have met face-to-face.

Don Tapscott's book Growing Up Digital: The Rise of the Net Generation stressed two sets of binary oppositions: between technologies (television versus Internet) and generations (baby boomers versus net generation) $)^{6}$. Author argues that technology offers new forms of empowerment for young people; that technology produces a wide range of social, psychological and political changes:

a) Mobile technologies create new styles of communication and interaction: web-based communication that fosters independence and autonomy, emotional and intellectual openness, innovation, free expression, immediacy, and an investigative approach. The internet provides new means for constructing community: it is an active and participatory medium, which is about many-to-many, distributed communication ${ }^{7}$.

b) The internet produces new styles of playful learning. Unlike the television generation, the net generation is inquisitive and selfdirected in learning. Net generation is more skeptical and analytical, more inclined towards critical thinking, and more likely to challenge and question established authorities than previous

6 D. Tapscott, Growing Up Digital: The Rise of the Net Generation, The MC Graw Hill Inc., New York 1998, p. 15.

7 Ibidem, p. 55-57. 
generation. Thus, net-based learning is interactive, rather than a matter of transmission. Where old-style education was teacher -dominated and authoritarian, digitally based education is non -linear and learner-centered, based on discovery rather than the delivery of information. The net transforms the teacher into a facilitator, whose input has to be customized to learners' needs ${ }^{8}$.

c) These new conditions of education, work and social life also require new competencies or new forms of literacy (among them visual literacy as key competency). This is apparent to some degree in the innovative, informal styles of language that are emerging on the internet - emoticons and so on - and in the changing conventions of language use. More broadly, however, internet communication is seen to require and produce new intellectual powers, and even more complex brain structures: it results in a kind of accelerated development. The net generation not only has different skills in terms of accessing and navigating through information, it also processes and evaluates information in a radically different way from the television generation. By offering communication with different aspects of the self, it enables young people to relate to the world and to others in more powerful ways ${ }^{9}$.

d) The internet is also seen to be leading to the emergence of a new form of politics. The net itself is more democratic: it is a collectively shared, non-hierarchical system that serves as "a medium for social awakening". Its effects on offline behavior are also inherently democratizing. According to Tapscott, the net generation is more globally-oriented, more inclined to exercise social and civic responsibility, and to respect the environment. Technology is radicalizing net generation, just as television has ultimately led the baby boomers to accept and enjoy the status quo ${ }^{10}$.

8 Ibidem, p. 125-130.

9 Ibidem, p. 85-105.

${ }^{10}$ Ibidem, p. 285-300. 


\section{M-learning as a concept}

The increasing availability and use of mobile devices is a part of the transformative impact of mobility and connectedness on contemporary societies. Alongside these developments, mobile learning and its educational values are discussed with a view to formalized learning contexts for almost 15 years in Western Europe (mainly in Britain and Germany).

The mobile learning discussions indicate that mobile learning provokes the deep insight into technology, learners, contexts, concepts, teaching design, ways of learning, places and times for learning, social developments, the educational system ${ }^{11}$. Authors write about learner-centered learning, opening of schools and universities for learners' everyday life, learning during leisure time and about "new" learning, about the shift of power levels in realization to access and distribution of knowledge, as well as about the democratization of learning ${ }^{12}$.

Despite attempts to define mobile learning as rigorously as possible there is not currently exist a definition of mobile learning that is generally accepted among the media education researchers. Mobile learning is defined as being "spontaneous, personal, contextual, portable, ubiquitous and pervasive"13. It can be also seen as highly situated, collaborative, personal and long term; truly learner-centered learning ${ }^{14}$. Mobile technology enables learners to learn "beyond classroom practices in which what is being taught is abstracted from its naturalistic, ecological space where it has real function with the world"15.

${ }^{11}$ J. Seipold, Mobile Learning. Structures, Concepts and Practices of the British and German Mobile Learning Discussion from a Media Education Perspective, "Medien Padagogik" 2014, no. 24, p. 31.

${ }^{12}$ L. Naismith, P. Lonsdale, G. Vavuola, M. Sharples, Literature Review in Mobile Technologies and Learning, "Futurelab Report" 2004, no. 11.

${ }^{13}$ A. Kukulska-Hulme, J. Traxler, Mobile Learning: A Handbook for Educators and Trainers, Routledge, London-New York 2005, p. 2.

${ }^{14}$ L. Naismith, P. Lonsdale, G. Vavuola, M. Sharples, Literature Review..., p. 36.

${ }^{15}$ N. Pachler, The Socio-Cultural Ecological Approach to Mobile Learning: An Overviews, in: Ben Bachmair, Medienbildung..., p. 154. 


\section{M-learning infrastructures in higher education}

M-learning is made possible by the existence and application of mobile hardware and networking technology. By exploring the capabilities of these technologies, it is possible to construct a picture of how different components of m-learning can be implemented and explores the major technologies currently in use: Tablets, Smartphones, Portable Digital Assistants (PDAs), Short Message Service (SMS) messaging via mobile phone, Bluetooth or WiFi and podcasts via MP3 players.

Online learning and blended instruction, both utilizing technology to convey educational content, are shifting from a model working only with e-learning to encompassing mobile learning (m-learning). This shift in learning locations and learner access to information is driven both by demand and by advances in technology that make mobile technology access a practical option for the average person. In examining the growth of these technologies it is possible to see the growth to date, and possibly the future direction of m-learning.

M-learning is broadly defined as the delivery of learning content to learners utilizing mobile computing devices. Kambourakis, Kontoni, and Sapounas defined it as, "The point at which mobile computing and e-learning intersect to produce an anytime, anywhere learning experience" 16 . The advantages of learning anytime and anywhere have long been near the top of the benefits listed by proponents of online education, but until the advent of m-learning technologies it was not really an anytime, anyplace environment. The demand for a learner to be physically at a computer and physically connected via some kind of cable to a network meant that learning locations were constrained. With constraints in place on the available learning locations, time constraints existed as well; someone taking classes using their computer at work might not have access to that resource at midnight or on Sunday afternoon ${ }^{17}$. Mobile learning is exactly that; mobile; m-learning as an educational method is new and

${ }^{16}$ G. Kambourakis, D.P.N. Kontoni, I. Sapounas, Introducing Attribute Certificates to Secure Distributed E-Learning or M-Learning Services, in: Proceedings of the IASTED INTERnAtional Conference, Innsbruck 2004, p. 436-440.

17 K. Petrova, Mobile Learning Using SMS: A Mobile Business Application. Proceedings for the $18^{T h}$ Annual Conference of the National Advisory Committee on ComPUting Qualifications, July 10-13, Tauranga, Australia, 2005, p. 412 k-417. 
more flexible than previous e-learning applications ${ }^{18}$. Learners can have the opportunity to review course materials or correspond with instructors or colleagues while sitting in a restaurant or waiting for a bus; they are not made immobile by the restrictions of desktop computer technology.

Because m-learning is such a new field the research is still in a stage where different categories of m-learning pedagogy are being developed, identified, and researched. With this developmental stage in mind, the very existence of m-learning, not to mention its growing application, is directly tied to the growth of mobile technology. This fact is why it is so important for researchers and practitioners to be familiar with mobile technology applicable to m-learning. It simply is not possible for someone to log onto a learning management system (LMS) wirelessly from a tablet, personal digital assistant (PDA) or smartphone if wireless networks do not exist or if the above mentioned do not support wireless connectivity.

Hardware advances are one of two key components to the emergence of m-learning, the other being networking. To be mobile technology, hardware had to advance to a point at which people would carry and access the device on a regular basis. It is generally accepted that devices like mobile phones, PDAs, and MP3 players fit into the category of mobile devices ${ }^{19}$. Sources disagree on the status of laptop and notebook computers as mobile devices. While they are capable of working without plugging into a power source and can utilize wireless networks, they are not devices that people can carry everywhere and quickly access at any time due to their size, configuration, and the time required to boot up and shut down. For the purposes of this paper, mobile technology will be described as a device that can fit in the average shirt or jacket pocket and be carried on a daily basis.

Wireless networking is the second technological component contributing to m-learning success. While some m-learning resources can be utilized in a non-networked, offline environment, many depend on access

18 T. Georgiev, E. Georgieva, G. Trajovski, Transitioning from e-Learning to $m$-Learning: Present Issues and Future Challenges. Proceedings of the $7^{\text {TH }}$ ACIS INTERNATIONAL C ONference on Softimare Engineming, Artificial Intelligence, Nethoring, and Parallel/ Distributed Computing (SNPD'06), 2006.

19 T. Iiyoshi, M.S. Kumar, Opening up Education: The Collective Advancement of Education through Open Technology, Open Content, and Open Knowledge, MIT Press, Cambridge, Mass. 2008. 
to the Internet to exchange information and access up-to-date information. To serve this need, mobile devices needed a way to access network resources without plugging into a land line connection. Currently the leading candidate for this technology is the IEEE 802.11 wireless communication standard, commonly called Wi-Fi. Also gaining ground in the market are wireless phone broadband connections and, to a lesser extent, the IEEE 802.15.1 wireless communication standard, commonly called Bluetooth. While Bluetooth is more frequently used as a device-to-device data transfer technology, its use as a network system is possible. Regardless of which standard is in use, wireless networking provides learners with the opportunity to connect with colleagues and instructors via online resources from a much broader variety of places than are accessible via traditional wired connections. An in-depth review of the technology will be explored in a later section, but it is important to recognize just how important this technology is in facilitating m-learning environments.

M-learning developed for enhanced collaboration via user-generated content: much of the content is created by learners to share with other learners, including but not limited to learning exercises, photo or video examples of concepts, podcasts or vodcasts, self-assessments, and lessons learned documents. This collaboration encourages constructivist -style user participation, discussion, teamwork, and collaboration.

M-learning for assessment of user performance or knowledge, developed to address a new assessment need: much of the content requires user input and evaluates the performance or knowledge acquisition of the user, often for self-assessment purposes. These assessments usually leverage unique mobile platform capabilities (such as location awareness and the device's built-in camera) and/or are contextually based (such as an assessment that requires the user to be in the process of using a piece of equipment). The content here can be redesigned from existing assessments, or constructed in response to a new assessment need.

The m-learning identifies and analyzes relevant information, resources, and literature relating to the mobile solution process, including important considerations to be addressed prior to and during a m-learning initiative. The m-learning guides educators in making decisions by describing decision points, good practices, and recommendations. It also illustrates how to apply the m-learning to sample projects. This not 
only educates educators on the nuances involved in m-learning solutions, but it also allows educators to provide justification for decisions that are made in their own projects. Thus, by referring to this m-learning, educators will be able to capitalize on the advantages that are offered by the mobile platform, as well as to avoid potential pitfalls that could compromise the ultimate success of the final product describes the target audience for the m-learning.

\section{Important theoretical framework}

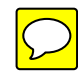

In the current mobile learning discussion few theories are recognized as powerful conceptual framework: social-cultural ecology of m-learning and learner-generated context theory.

\section{Socio-Cultural Ecology of Mobile Learning}

The London Mobile Learning Group tries to provide a framework for the analysis of mobile learning which does not only highlight one specific aspects of mobile learning practices but also includes socio-economical and technological structures, agency of learners and their cultural practices $^{20}$. By doing so, the learners life-world became a starting point for the appropriation of cultural resources such as mobile devices via agency and cultural practices within given or created structures. Appropriation is here understood as a process of producing and receiving engagement when students use mobile technologies. This process is described also as subjectively meaningful: students engage in meaning-making. Both, appropriation and meaning making is defined as situated, contextualized and subjectively shaped ${ }^{21}$. Learning - if understood as appropriation - is described as a process of meaning-making within the arrangements of social and technological structures, cultural practice and agency. For the mobile learning discussion the introduction of such model means a systematic extension of the domain of the learners' subjectively meaningful appropriation and meaning-making with the aim to position oneself in

\footnotetext{
${ }^{20}$ N. Pachler, The Socio-Cultural Ecological..., p. 153-167.

21 Ibidem, p. 155.
} 
relation to everyday life or educational context ${ }^{22}$. Obviously, it offers prospects for education and formation.

\section{Learner Generated Context}

Alternative to the Social-Cultural Ecology concept is Learner Generated Contexts which is used to describe and understand the situational attitude of appropriation and the changes within the pattern of appropriation depending on place, time and availability of cultural resources $^{23}$. By referring to the context, formal and informal mobile learning situations and processes become describable, comprehensible and plannable for learning. Learner Generated Contexts concept gains importance because the context concept moves the focus away from user-generated contents and away from the idea of learning tools and pre-set learning contents. The increasing importance of agency of learners, technologies, structures, networks and contents creating within everyday life of students as well as within educational settings makes this concept powerful. This new concept also provides links to current developments in communication and to the contemporary understanding of learning as meaning-making in formal and non formal structures. Both move away from idea of learner being consumers of pre-given contents towards an idea of learners as producer of self-chosen and self-created contents: within contexts, students act in flexible ways and are able to adjust resources to the demands and conditions of contexts ${ }^{24}$.

\section{Implementation of mobile learning in classroom-based learning practice}

Three common ways to implement mobile learning are identified in formalized educational settings. Often mobile devices are implemented into learning contexts from top to bottom (top-down approach) ${ }^{25}$. It me-

22 Ibidem, p. 156.

${ }^{23} \mathrm{E}$. Brown, Introduction to Location-Based Mobile Learning, in: Education in the Wild: Contextual and location-based mobile learning in action, ed. E. Brown, EJB, Nottingham 2010, p. 7-9.

${ }^{24}$ Ibidem, p. 42.

25 J. Seipold, Mobile Learning..., p. 42. 
ans that the devices are set-up onto already existing teaching and learning structures. Those are the cases of large budget projects in which whole departments or study programs are provided with mobile devices such as tablets. This approach implies strong regulation what means that students find themselves in pre-set and given technological infrastructure and scopes of action but this situation give them the equal opportunities within the learning process. This may be extremely important for the learners who are disadvantaged socio-economically and on an infrastructural level.

The alternative to the previous one is the bottom-up approach which consists on taking available resources, such as devices and know-how of students and teachers into account ${ }^{26}$. This approach obviously saves cost because devices do not need to be supplied and the students feel confident with their devices. Classroom seems to be open to the interests, competencies and knowledge based on the everyday life of students. However this approach can bring unexpected infrastructural challenges and obstacles for learning in terms of connectivity and technological transparency.

The third possible approach is demand-oriented one ${ }^{27}$. This is an option closest to the everyday use of mobile technologies. The devices, applications and practices are used only when users teachers and students consider them necessary or helpful or when they are apply selectively and explicitly as teaching and learning tools. Such arrangements need to guarantee the seamless use of mobile technologies in class as well as outside it. Apart from this demand-oriented approach allows universities to be open to technology use in everyday life as appropriate and allows the design of lectures and workshop by keeping instructional, communicative and discursive learning, individual or in groups. Also it provides the wider selection among formal learning materials and resources or to refer to everyday life informal resources.

${ }^{26}$ Ibidem, p. 43.

${ }^{27}$ I. Arnedillo-Sanchez, The Mobile Digital Narrative Tool, in: Mobile Learning, ed. I. Arnedillo-Sanchez, P. Isaias, IADISA, Lisbon 2008, p. 77-83. 


\section{M-learning outcome. Beyond the "wow" effect}

Evaluation of m-learning outcomes and applications are not an easy task. Learners even mature enough enjoy using mobile devices for learning and declare immediate increased motivation as a result of this use. Among the main benefits of m-learning are mentioned: facilitates access to, management of, and sharing of information, fosters students' learning and performance, allows a wider range of teaching strategies, fosters individualized learning, encourages communication and collaboration among students and between teachers and students, improves computer literacy skills and multimedia presentations, nurtures students' creativity, facilitates student assessment, improves the quality of pedagogical support $^{28}$.

Jones proposes an initial set of factors that contribute to the high affective value of mobile learning: control over goals, ownership, fun, communication, learning-in-context, and continuity between contexts. Specifying the attributes that make mobile devices attractive for learning and understanding how exploit these attributes is also an issue worthy of further analyses. Thus, in the context of mobile learning evaluation, the effort should also be to see beyond the initial wow effect, into how inclusive and powerful this is in engaging the learner over the llonger term projects $^{29}$.

\section{POJECIE MOBILNEGO UCZENIA SIEC. INFRASTRUKTURA M-LEARNING W EDUKACJI WYŻSZEJ}

\section{Streszczenie}

W ostatnich 15 latach idea mobilnej edukacji (m-learning) zyskała na znaczeniu: począwszy od mniejszych projektów, skończywszy na dużych projek-

${ }^{28}$ M.Jones, G. Marsden, Mobile Interaction Design, John Wiley and Sons Ltd, Chichester 2006.

${ }^{29}$ M.Jones, K. Isroff, E. Scanlon, Affective factors in learning with mobile devices, [in:] M. Sharples (ed). Big Issues in Mobile Learning:Report of a workshop by the Kaleidoscope Network of Excellence Mobile Learning Initiative, University of Nottingham 2006, pp. 14-19. 
tach dotyczących infrastruktury m-learningowej w obszarze wyższej edukacji. Rezultaty tych projektów wskazują, że mobilne technologie tworzą nowe możliwości w zakresie uczenia się wykraczającego poza tradycyjny wzorzec aktywności klasowej, kierowanej przez nauczyciela. W artykule znajduja się odniesienia do edukacyjnego znaczenia mobilności i kontekstu istotnych $z$ punktu widzenia m-learningu. Główne założenia prezentowanego artykułu zawarte sa w następującej formule: mobilne technologie sa wyzwaniem dla transmisyjnego modelu nauczania w edukacji wyższej, sprzyjaja zindywidualizowanemu uczeniu się oraz komunikacji i współpracy zachodzącej między studentami reprezentującymi pokolenie cyfrowe a nauczycielami.

Słowa kluczowe: mobilna edukacja (m-learning), edukacja wyższa, cyfrowe pokolenie, mobilne technologie

Przekład: Lucyna Kopciewicz

\begin{abstract}
Over the past fifteen years mobile learning has grown from a minor research interest to the set of significant projects in higher education. The outcomes of these projects show that mobile technologies offer new opportunities for learning that extend within and beyond the traditional teacher-led classroom. The theory of mobile learning described here puts mobility and context as the objects of analysis. The main assumption adopted here is that mobile technologies challenge the dominant transmissive paradigm of teaching in higher education, foster individualized learning, and encourage communication and collaboration among new "digital generation" of students as well as between teachers and students
\end{abstract}

Keywords: mobile learning (m-learning), higher education, digital generation, mobile technologies 


\section{Andrzej Marciniuk}

Wyższa Szkoła Oficerska Sił Powietrznych

\section{Kształcenie specjalne personelu latającego w „Szkole Orląt” w latach 1925-1939}

Dęblińska „Szkoła Orląt” kształci personel latający od 90 lat. Ze względu na straty wojenne, jakie Szkoła poniosła w II wojnie światowej, jej przedwojenne osiagnięcia dydaktyczne uległy zapomnieniu. $Z$ perspektywy współczesnej dydaktyki lotniczej w Pracowni Historii Sztuki Wojennej i Dydaktyki Lotniczej Wyższej Szkoły Oficerskiej Sił Powietrznych w Dęblinie prowadzone sa badania w celu odtworzenia przedwojennych: treści programów kształcenia i metodyki szkolenia lotniczego pilotów i obserwatorów.

Dęblińska „Szkoła Orląt” kształci personel lotnictwa wojskowego od 90 lat. Polskie lotnictwo wojskowe miało już pierwsze doświadczenia szkoleniowe i bojowe, kiedy rozpoczęto kształcenie w niej pilotów i obserwatorów. W latach 1919-1925 szkolono personel lotnictwa w szkołach w Warszawie, Poznaniu, Krakowie, Toruniu, Grudziądzu i Bydgoszczy. Polscy piloci nabyli doświadczenia bojowe $\mathrm{w}$ walkach na froncie ukraińskim, w powstaniu wielkopolskim oraz w wojnie z Rosją Radziecka w 1920 roku. Decyzję o utworzeniu szkół pilotów i personelu technicznego lotnictwa w Dęblinie podjęto w lipcu 1919 roku w Ministerstwie Spraw Wojskowych. Od maja 1920 roku w Dęblinie kształcono polskich pilotów w przybyłej z Armią gen. Józefa Hallera Francuskiej Szkole Pilotów. W wyniku działań bojowych na froncie wojny polsko-bolszewickiej Szkołę przeniesiono do Bydgoszczy ${ }^{1}$.

Od 1921 roku rozbudowano bazę dydaktyczna, socjalną i lotnisko w Dęblinie, tworząc nowoczesną szkołę lotniczą. Równolegle $z$ rozbudową infrastruktury lotniczej, dydaktycznej i socjalnej oraz zakupami nowego sprzętu

\footnotetext{
1 Kontynuowano w niej szkolenie pilotów - podoficerów i oficerów - nawet po zmianie nazwy na Centralną Szkołę Podoficerów Pilotów Lotnictwa.
} 
dla jednostek bojowych i szkolnictwa lotniczego przygotowywano nowe programy kształcenia i szkolenia personelu w powietrzu. Programy te tworzyli polscy absolwenci szkół lotniczych zaborców oraz wyszkoleni we Francji.

Wraz z zakupami nowoczesnego sprzętu lotniczego we Francji przyśpieszono utworzenie 1 listopada 1925 roku Oficerskiej Szkoły Lotnictwa (OSL). Do praktycznej realizacji zadań nowoczesnego kształcenia w niej kandydatów na oficerów wytypowano najlepszych wykładowców i pilotów instruktorów z rozwiązanej Wyższej Szkoły Pilotów (WSP) w Grudziądzu. Od pierwszych dni funkcjonowania OSL charakteryzowała wysoka jakość prowadzonych w niej zajęć z przedmiotów ogólnokształcących, specjalistyczno-lotniczych i ogólnowojskowych. Na pierwszym roku studiów podchorążowie ukończyli szkolenie na samolocie Morane-Saulnier MS-35 EP2. Było to znaczace osiagniecie kadry dydaktycznej Szkoły, gdyż potrafiła ona oprócz zajęć teoretycznych wyszkolić podchorą̇ych w pilotażu poczatkowym. W kwietniu 1927 roku przeniesiono OSL do nowoczesnej siedziby w Dęblinie, którą budowano od 1921 roku.

W międzyczasie, po roku funkcjonowania OSL w Grudziądzu (1926), zmieniono programy nauczania, kształcąc tylko podchorążych w specjalności obserwatora.

Kształcono obserwatorów, których obowiązki tak precyzował „Regulamin Lotnictwa" w pkt 47:

obserwator wykonywa najbardziej odpowiedzialne zadania na korzyść dowódców i oddziałów. Szczególne ważne jest rozpoznanie na korzyść dowódców, gdzie wiadomości dostarczone przez niego częstokroć zaważyć moga na losach całego działania. Zakres stawianych zadań wymaga od niego nie tylko doskonałego wyszkolenia w praktycznym użyciu sprzętu, potrzebnego do wykonywania zadań, lecz także gruntownej znajomości działania oddziałów, na których korzyść pracuje (piechota, artyleria, kawaleria), oraz znajomości ogólnych zasad taktyki oddziałów nieprzyjacielskich. Ze względu na ogrom stawianych zadań i wymagań (szybka orientacja, obserwacja i decyzja) oraz odpowiedzialność, jaka na nim ciąży, obserwator jest dowódca załogi każdego samolotu ${ }^{2}$.

Zaprzestano kształcenia w niej podchorażych pilotów do 1935 roku. Podchorążowie w dęblińskiej „Szkole Orlatt” zdobywali uprawnienia obserwa-

2 Regulamin Lotnictwa został oficjalnie wydany w $1931 \mathrm{r}$. Konsultacje nad jego treścia trwały kilka lat. 
tora przez 2 lata. Przed OSL musieli ukończyć roczne przeszkolenie ogólnowojskowe w Szkole Podchorażych Piechoty. Na I roku OSL, po 10 miesiącach zajęć teoretycznych i praktycznych, odbywali miesięczna praktykę w pułku lotniczym. Na II roku zajęcia te trwały dziewięć i pół miesiąca i po promocji 15 sierpnia rozpoczynali służbę $\mathrm{w}$ jednostkach bojowych lotnictwa.

OSL od chwili utworzenia była jednostka wojskowa, wojskowa szkoła zawodową i przygotowywała absolwentów do objęcia pierwszego stanowiska służbowego w pułku lotniczym. Proces kształcenia w niej był tak zorganizowany, by po zajęciach teoretycznych podchorażowie mogli praktycznie przećwiczyć omawiane teoretycznie zagadnienia. Dobierano treści kształcenia $z$ przedmiotów tzw. zawodowych, by w uzupełnieniu o zapisy zawarte $\mathrm{w}$ regulaminach i instrukcjach wojskowych oraz lotniczych dały podchorążym specjalne kompetencje do wykonywania zawodu lotniczego. Rada Pedagogiczna Szkoły, Dyrektor Działu Nauk czuwali nad współdziałaniem wykładowców $z$ instruktorami w celu ustalenia ogólnych metod prowadzenia wykładów, ćwiczeń i zajęć praktycznych, aby uniknąc rozbieżności między wyszkoleniem teoretycznym i praktycznym.

W czasie zajęć w Dęblinie podchorążowie uczestniczyli w wykładach, pokazach, ćwiczeniach, treningach specjalistycznych. Odbywali zajęcia praktyczne na samolotach, trenażerach (np. w ciemni bombardierskiej, wyżce bombardierskiej) oraz na strzelnicach sportowych i bojowych, w laboratoriach i pracowniach przedmiotowych. Obowiązkiem wykładowców i instruktorów przedmiotów specjalistyczno-lotniczych było prowadzenie treningów w zastosowaniu uzbrojenia lotniczego, wyposażenia pokładowego samolotów. Samoloty bojowe $z$ pełnym wyposażeniem były do dyspozycji szkolonych pod nadzorem instruktorów, w hangarach Działu Nauk. Dopełnieniem zajęć teoretycznych i praktycznych były ćwiczenia wykonywane w czasie lotów na samolotach szkolnych: bombowych i liniowych. Zajęcia odbywały się w czasie całych studiów.

Podstawa tego procesu kształcenia było przyswojenie przez podchorażego zasad pilotowania statków powietrznych (do 1926 r.), ich eksploatacji, użycia środków nawigacyjno-bombardierskich oraz strzelania powietrznego w powiąaniu $z$ najnowszą taktyką walki powietrznej ${ }^{3}$. Ponad-

3 W 1929 r. stwierdzono poważny niedobór pilotów i podjęto decyzje o przeszkoleniu na 6-miesięcznych kursach pilotażu absolwentów dęblińskiej OSL, a od 1928 r. Szkoły Podchorązych Lotnictwa (SPL). 
to, umiejętnościami: prowadzenia rozpoznania lotniczego, korygowania ognia artylerii, utrzymania łączności z piechota i kawaleria, niszczenia celów w powietrzu i na ziemi, by mogły być zastosowane zaraz po ukończeniu uczelni w działalności zawodowej.

W treści kształcenia zawodowego wyróżniano wiedzę zawodowa i umiejętności zawodowe. W procesie kształcenia zawodowego obok metod i form nauczania teoretycznego stosowano formy i metody nauczania praktycznego oraz nauczanie przez uczestnictwo w praktycznej działalności (np. nauka pilotażu, strzelania powietrznego, fotografowania celów, przekazywania meldunków $\mathrm{z}$ rozpoznania, lotów w szyku samolotów, podstaw taktyki walki). Najważniejszym celem było integrowanie przygotowania teoretycznego $z$ praktycznym.

OSL-SPL jako szkoła zawodowa różniła się od innych szkół wojskowych nie tylko przyjętymi do realizacji celami kształcenia, ale i doborem oraz układem treści programowych, w szczególności tym, że zastosowano tu specyficzne nauczanie przez działanie (trenażery do nauki pilotażu, strzelania powietrznego i bombardowania oraz inne), co wymagało stosowania niewystępujacych gdzie indziej metod nauczania.

Podstawowym dokumentem projektujacym proces kształcenia zawodowego w Szkole była charakterystyka (sylwetka) zawodowa określająca wskazówki co do stanu psychofizycznego kandydata, poziom jego wykształcenia ogólnego, opinię lub rekomendacje ze środowiska, z którego pochodził, dość szczegółowo wiedzę i umiejętności, jakie musi posiadać absolwent, wykaz czynności i kompetencji, jakie musi nabyć, by objąć pierwsze stanowisko służbowe ${ }^{4}$. Charakterystyka zawodowa wpływała na właściwy dobór materiału do realizacji $z$ odpowiednich dyscyplin naukowych, ale w przypadku szkoły lotniczej określała treści działalności praktycznej gwarantującej nabycie odpowiednich umiejętności. Określono wówczas ważność różnych części materiału, a to $z$ kolei warunkowało przydział czasu na realizację, podział treści nauczania na poszczególne przedmioty. Implikowało to ustalenie liczby i specjalności personelu instruktorskiego na ziemi i do szkolenia w powietrzu, środków dydaktycznych, w tym samolotów wraz z częściami zamiennymi, uzbrojenia, sprzę-

4 Autorowi udało się wyodrębnić podstawowe ustalenia dotyczace modelu osobowo-zawodowego w pierwszych dokumentach normatywnych „Szkoły Orlat" pt. Projekt regulaminu tymczasowego OSL, Grudziądz 1925 (?) i Program OSL. Kurs dwuletni, Dęblin 1928. 
tu materiału fotograficznego, paliwa, bomb, amunicji i innych. Uwzględniajac warunki meteorologiczne sprzyjajace szkoleniu lotniczemu podchorażych (w naszej szerokości geograficznej od kwietnia do października), ustalono przemienność kształcenia i szkolenia lotniczego. Gros kształcenia teoretycznego prowadzono od listopada do marca. Ustalając treści przedmiotów: ogólnych, politechnicznych i zawodowo-lotniczych, zaplanowano kolejność ich rozpoczynania i zakończenia. W działalności dydaktycznej stosowano się do powszechnie znanych metod nauczania (szkolenia). Stosując się do zasady świadomej aktywności, podkreślić należy, że uczniowie (podchorążowie, oficerowie), by osiagnać sukces (np. wyszkolić się w pilotażu), musieli z zaangażowaniem współpracować z pilotem- instruktorem w procesie szkolenia lotniczego. Współuczestnicząc w szkoleniu, wykazać się musieli różnymi formami aktywności, od bezładnej poprzez naśladowcza (kopiująca), zamierzona ( naśladowcza), aktywnością kierowana zadaniami, a skończywszy na najwyższej formie - aktywności twórczej (np. bombardowanie w locie eskadrą samolotów).

Świadoma aktywność połączona $\mathrm{z}$ samodzielnościa w myśleniu i samodzielnością $\mathrm{w}$ działaniu wiązano $\mathrm{z}$ zasada indywidualizacji. Szkolenie w powietrzu wymagało od pilotów-instruktorów stosowania dobranych metod pozwalających na rozwijanie postawy samodzielności u kandydatów na pilotów czy obserwatorów. Służyć temu miało w sposób naturalny $\mathrm{w}$ szkoleniu lotniczym podejmowanie decyzji w czasie wykonywania lotu przez pilota czy zadania specjalistycznego przez obserwatora (np. prowadzić czy przerwać przelot, eskadry samolotów przy pogarszających się warunkach atmosferycznych; mogła zaistnieć sytuacja np. utraty orientacji przestrzennej, kolizji samolotów w chmurach).

W dęblińskiej „Szkole Orląt” uczeń-pilot (obserwator) musiał zdecydować, czy jego wiadomości, umiejętności, rozpoznanie zagrożenia, właściwa ocena sytuacji w powietrzu sa dostateczne, by mógł podjąc działanie, np. czy jest gotowy podjaćc ryzyko przymusowego lądowania w terenie przygodnym, czy będzie kontynuował lot do lotniska z uszkodzonym silnikiem. Znajomość zasad szkolenia lotniczego przez ówczesnych pilotów-instruktorów pozwalała w sposób rozważny, odpowiedzialny (przy zagrożeniu życia swojego i szkolonego podchorażego) kształcić samodzielność podchorążych poprzez wdrażanie ich do podejmowania decyzji zarówno w działaniu umysłowym, jak i praktycznym (symulacja zagrożeń w powietrzu). Szczegól- 
nie wykonywanie lotów szkolnych przez personel latający stwarzało takie uwarunkowania w powietrzu (dydaktyczne), gdzie szkolony podchoraży był zmuszony zaistniałą sytuacja do podjęcia decyzji. Tak jak wspomniano wcześniej, uświadamiano szkolonym, że umiejętność podjęcia właściwej decyzji w zawodzie pilota to czasami sprawa życia i śmierci. W pełni wiązało się to $z$ urzeczywistnianiem zasady łączenia teorii $z$ praktyka.

Program studiów OSL przewidywał 2200 godzin zajęć z 41 przedmiotów 5 . Na I roku było 618 godzin wykładów i 524 godziny ćwiczeń praktycznych. Na II roku było 524 godziny wykładów i 521 godzin ćwiczeń praktycznych.

Od 1928 roku kształcono w Dęblinie szeregowych z cenzusem na oficerów rezerwy lotnictwa w Szkole Podchorążych Rezerwy Lotnictwa (SPRL). Program studiów w SPRL obejmował podobna tematykę przedmiotów jak w SPL. Kształcenie i szkolenie w powietrzu trwało 14 miesięcy. Łącznie program zajęć przewidywał 397 godzin wykładów i 130 godzin treningów i ćwiczeń w obiektach dydaktycznych szkoły, a także 55 godzin wykładów i 320 godzin ćwiczeń i treningów na ziemi oraz w powietrzu w eskadrze ćwiczebnej szkoły.

W obu szkołach w czasie przemiennego kształcenia i szkolenia w powietrzu przygotowywano obserwatorów do praktycznego stosowania wiedzy teoretycznej włącznie $\mathrm{z}$ zastosowaniem jej do działań bojowych. $\mathrm{Na}$ przykładzie tematów wykładów, ćwiczeń w pracowniach, laboratoriach, zajęć praktycznych na sprzęcie lotniczym w hangarze, strzelnicach szkolnych i bojowych, zajęć $z$ praktycznego zastosowania bojowego w powietrzu z przedmiotów: „regulamin lotnictwa” i „wyszkolenie strzeleckie i bombardowanie" można prześledzić szczególną złożoność procesu przygotowania personelu latającego.

W ramach przedmiotu „regulamin lotnictwa” po 30 godzinach zajęć teoretycznych, gdy uczono podchorążych sporządzania szkiców, meldunków, sprawozdań z rozpoznania lotniczego, redagowali oni radiodepesze, rozwiazywali konkretne zadania wynikajace $z$ rozkazów operacyjnych dotyczących użycia artylerii, łączności, piechoty, kawalerii. Ćwiczenia teoretyczne prowadzono $z$ wykorzystaniem stołu plastycznego $z$ odwzorowana

5 Dokładnej analizy programów kształcenia obserwatorów autor dokonał w pracy badawczej realizowanej w Wyższej Szkole Oficerskiej Sił Powietrznych w 2008 r.: Kształcenie obserwatorów w Dęblinie w latach 1927-1939. 
sytuacją taktyczna. Wykorzystywano również środki audiowizualne. Następnie odbywały się ćwiczenia w powietrzu z zakresu współdziałania lotnika z piechota, kawaleria, artyleria poprzez wyszukiwanie celów dla artylerii (korygowanie jej ognia). Wyszukiwano i określano za pomoca rakiet i kolorowych dymów pozycje nieprzyjaciela. W zakresie wykształcenia tego typu umiejętności podchorażzowie po długotrwałych ćwiczeniach wykonywali minimum 9 lotów szkolnych i szkolno-bojowych, a w drugim roku nauki 6 lotów szkolno-bojowych, aż do pełnego opanowania umiejętności.

W trakcie "wyszkolenia strzeleckiego ${ }^{6}$ i bombardowania” przekazywano praktyczna wiedzę $z$ balistyki, pirotechniki i budowy uzbrojenia oraz jego zastosowania w walce. Bardzo dokładnie nauczano budowy uzbrojenia lotniczego, w tym urządzeń celowniczych oraz obrotników, na których montowano karabiny maszynowe dla obserwatora (strzelca pokładowego). Rozpoczynano zajęciami teoretycznymi, przechodząc płynnie do prezentacji środków uzbrojenia, a następnie podchorążowie mieli zajęcia praktyczne $z$ bronią. Uczyli się składania i rozkładania broni oraz urządzeń pokładowych zainstalowanych na stanowisku strzeleckim w samolocie. Trenowali ładowanie amunicji do taśm i ładowników. Kolejną czynnościa, jaką wykonywali pod nadzorem instruktora, było usuwanie zacięć karabinu maszynowego obserwatora. Wszystkie poznane przez podchorązego czynności praktyczne obsługi broni powtarzano aż do uzyskania przez podchorażego efektu w postaci pełnej automatyzacji wykonywania czynności na uzbrojeniu zamontowanym już na samolocie bojowym. Samolot był holowany $z$ lotniska i ustawiony w hangarze kompleksu dydaktycznego Działu Nauk.

Zajęcia $\mathrm{z}$ nauki o broni lotniczej skorelowane były $\mathrm{z}$ wykładami, ćwiczeniami teoretycznymi, pokazami, treningami z przedmiotu „zasady

6 Centralne Archiwum Wojskowe (dalej: CAW), 3217, Kurs strzelania powietrznego, do użytku oficerów instruktorów strzelania i podoficerów strzelców lotniczych. Tłumaczenie z języka francuskiego. Wyd. Ministerstwa Spraw Wojskowych, Departament Lotnictwa, Warszawa 1927, s. 7 . W podręczniku wskazano różnicę pomiędzy strzelaniem powietrznym a strzelaniem wykonywanym w wojskach lądowych. „Porównując strzelanie powietrzne ze strzelaniem ziemnem, widzimy, że zagadnienie strzelania powietrznego jest złożone. Przy strzelaniu ziemnem żąda się od strzelca, leżącego na ziemi z bronią zamocowaną na ciężkiej podstawie, aby strzelał na znaną odległość do celu nieruchomego lub bardzo wolno poruszającego się. Lotnik, lecąc na samolocie zwrotnym, drgającym, opadając lub wznosząc się, musi wykonać pod grozą śmierci celny ogień do przeciwnika poruszającego się również jak i on z wielką szybkością w rozmaitych kierunkach, odległość do którego zmienia się bardzo szybko". 
strzelania powietrznego". Przedstawiano podchorażym uwarunkowania: taktyczne, pilotażu i strzelania, prowadzonej przez pilota i obserwatora walki powietrznej. Oprócz opisu zasad strzelania w powietrzu zapoznawano podchorążych $z$ organizacją treningów i strzelań, w tym przestrzeganiem warunków bezpieczeństwa w celowaniu, strzelaniu ze specjalnie dla lotnictwa przygotowanej szkolnej broni i amunicji strzeleckiej oraz strzelania $z$ ostrej amunicji na strzelnicy lotniczej. Opisywano cele stosowane w strzelaniach ćwiczebnych, szczególnie w treningach w celowaniu niezbędnych w nabyciu wprawy oraz wyćwiczenia odruchów strzeleckich. Wdrożono skonstruowane we Francji, pomocne w strzelaniu powietrznym urządzenia celownicze (np. celowniki: Reille-Soult, optyczny Chretien). Przyjęto do realizacji wypracowane przez lotnictwo francuskie sposoby ich wykorzystania dla wytrenowania nawyku u obserwatora (pilota) szybkiej oceny odległości i wprowadzenia poprawki celu, jaką należy uwzględnić przy oddaniu strzału. Służyły temu przyrządy pomocnicze do wyszkolenia strzeleckiego i specyficzne metody wyszkolenia. Były to: przyrzad Perrin-Pelletier ${ }^{7}$, „samoloty modele i karabiny maszynowe-modele ${ }^{8}$, tarcze samolotów jako cele ${ }^{9}$, strzelanie fotograficzne"10.

Równolegle do przedmiotów specjalistycznych lotniczych prowadzono $z$ podchorążymi i pilotami oraz obserwatorami-instruktorami zajęcia

7 Przyrząd ten pozwala obserwatorowi (pilotowi) przy stukrotnym pomniejszeniu odległości między walczącymi samolotami określić właściwy punkt celowania, a tym samym instruktor może ocenić prawidłowość wykonania poprawki strzelania do samolotu przeciwnika dokonanej przez obserwatora.

8 Urządzenie stosowane było w ćwiczeniu służacym szkolonemu do dokładnego określania i wykonywania poprawek celu za pomoca celownika optycznego np. Chretien. Uczyło strzelca odpowiedniej oceny odległości do celu, automatycznego określania dokładnej wartości i kierunku zastosowania poprawki celu oraz praktycznego zastosowania celownika.

9 Ćwiczenie polegało na rozpoznaniu $z$ odległości np. $40 \mathrm{~m}$ pomniejszonych na rysunkach sylwetek samolotów przeciwnika, ocenie szybkości, z jaką moga wykonywać lot wznoszący lub „pikować” i na komendę instruktora obserwator strzelał w kierunku celu. Część strzelań wykonywano na czas, wykorzystując zamontowany na strzelnicy obrotnik ustawiony wówczas skośnie do tarczy przez obserwatora. Na komenda do otwarcia ognia z k.m. obserwator kierował broń na obrotniku do tarczy. Obliczając stosowne poprawki, strzelał krótkimi seriami. Instruktor oceniał czas reakcji strzelca, poprawność wniesionych poprawek i wyniki strzelania.

${ }^{10}$ Strzelanie $z \mathrm{k} . \mathrm{m}$. foto do celów powietrznych miało za zadanie wyrobienie $\mathrm{u}$ pilota umiejętności manewrowania samolotem potrzebnej do wykonania czynności związanych z celowaniem $z$ k.m. do przeciwnika i jego ostrzelaniem. Urzadzenie to pozwalało skontrolować efekty wyszkolenia bojowego załogi w umiejętności prowadzenia walki powietrznej. 
z przedmiotu „wyszkolenie strzeleckie". Wykonywali oni strzelania z pokładowej broni maszynowej obserwatora i pilota na specjalnie wybudowanej strzelnicy. Dopełnieniem tych strzelań $\mathrm{w}$ ramach treningu były zajęcia ze strzelania ziemnego $z$ broni przystosowanej do strzelania szkolnego [np. strzelania ostre do samolotów-modeli na odległości skrócone (zmniejszone) i strzelanie do rzutek] ${ }^{11}$. Część strzelań na ziemi podchorażowie wykonywali w kompletnym ubiorze lotniczym (w tym używając okularów i grubych rękawic lotniczych) z pozycji siedzącej i stojąc w specjalnym koszu. Był on umocowany na niestabilnym podłożu (specjalnym wózku imitującym warunki pracy obserwatora w kabinie samolotu) przesuwanym w zależności od odległości do celu, w osi prostopadłej do tarczy. W ramach strzelania na ziemi podchorą̇y wykonywał:

a) 4 strzelania $z$ broni długiej (będącej na wyposażeniu piechoty);

b) 3 strzelania $z$ l.k.m. (Levis ziemny) na odległości skrócone;

c) 2 strzelania w ubraniu lotniczym $z$ k.m. Vickers na odległości skrócone (do $50 \mathrm{~m}$ );

d) 3 strzelania $z$ k.m. Vickers ziemnego na odległości skrócone;

e) 1 strzelanie $z$ k.m. Vickers ziemnego na usuwanie zacięć;

f) 18 strzelań w ubraniu lotniczym na odległości skrócone do samolotów modeli (strzelanie $z$ Floberta sprzęgniętego $z$ k.m. Vickers obserwatora);

g) 3 strzelania ze śrutówki $z$ wolnej ręki;

h) 5 strzelań ze śrutówki na obrotniku.

Ostatnim etapem szkolenia podchorażych w strzelaniu powietrznym było strzelanie szkolne $z$ samolotu. Pierwszy rocznik podchorażych obserwatorów wykonywał następujące zadania $z$ samolotu:

1. Strzelanie $z$ k.m. do celu stałego $z$ wysokości $200 \mathrm{~m}$ (w ładowniku było 30 naboi). Strzelanie nie było oceniane.

${ }^{11}$ Strzelania wykonywano np. z karabinu piechoty, który był przymocowany do dwóch karabinów maszynowych Levis - zdwojonych. Przyrządy celownicze karabinu maszynowego (np. celownik optyczny Chretien) były tak ustawione, by obserwator miał wrażenie, że celuje i strzela $z$ karabinu maszynowego, gdyż z k.m. Levis strzelano ślepa amunicją powodująca odrzut broni jak przy strzelaniu ostrym. Podchoraży SPL czy SPRL wykonywał w Szkole minimum 39 strzelań programowych $z$ broni szkolnej i k.m. Strzelanie do rzutek wykonywał podchorąży $z$ dubeltówki przystosowanej do umocowania jej na obrotniku wraz z k.m. Levis. Rzutki były wyrzucane ręcznie lub mechanicznie. Taki trening personelu latającego był stosowany w szkolnictwie i jednostkach lotniczych. 
2. Strzelanie $z$ k.m. do celu stałego $z$ wysokości $200 \mathrm{~m}$ (w ładowniku było 50 naboi). Strzelanie oceniane.

3. Strzelanie $z$ k.m. do celu przypuszczalnie ruchomego $z$ wysokości $200 \mathrm{~m}$ (w ładowniku 50 naboi).

4. Strzelanie $z$ k.m. do celu przypuszczalnie ruchomego widzialnego pod katem $45^{\circ} \mathrm{z}$ wysokości $200 \mathrm{~m}$ (w ładowniku 97 naboi).

5. Powtórzenie strzelania $\mathrm{nr} 4 \mathrm{w}$ razie niewykonania zadania.

6. Na II roku przewidziano kolejne zajęcia praktyczne ze strzelania:

7. Strzelanie do celu przypuszczalnie ruchomego $z$ wysokości 200 m, z dwóch k.m. sprzęgniętych (liczba naboi do 97).

8. Dwie walki powietrzne $z$ użyciem dwóch k.m. sprzęgniętych tak, że jeden strzela nabojami ślepymi, a drugi był połączony $z$ aparatem foto Thornton Picard ${ }^{12}$. W każdej walce wykonywano 6 zdjęć. Wysokość wykonywania ćwiczenia (walki powietrznej) 800-1000 m.

9. Dwa strzelania do spadochronów $z$ dwóch sprzęgniętych k.m. Jeden karabin strzelał nabojami ślepymi, a drugi był polaczony $z$ aparatem foto Thornton Picard. W obu walkach wykonywano po 6 zdjęć. Wysokość wykonywania zadania $1500 \mathrm{~m}$, dodatkowo dwa strzelania $z$ fotokarabinu do rękawa „H” $\mathrm{H}^{13}$ - wysokość wykonywania zadania 800-1000 m.

$Z$ przedmiotu „bombardowanie” podchorążowie opanowali niżej wymieniona problematykę zajęć teoretycznych: zasady bombardowania lotniczego, opis i użycie celownika S.T. Ae. oraz jego zasady funkcjonowania, posługiwanie się celownikiem, jego regulacja, inne celowniki stosowane w lotnictwie, ogólne opisy dotyczace bomb ostrych, zasady działań zapalników stosowanych w lotnictwie polskim, przyrządy zrzutowe, systemy zawieszenia, ładowanie bomb na płatowiec i wyładowanie, sposoby celowania, korygowanie błędów w kierunku i na donośność, cele do bombar-

${ }^{12}$ Od 1926 r. w szkolnictwie lotniczym w Polsce stosowano w strzelaniu powietrznym fotokarabin maszynowy Thornton Picard. W Anglii, Francji, USA stosowany on był w szkoleniu personelu latającego od $1918 \mathrm{r}$.

${ }^{13}$ Rękaw cel, tzw. rękaw H, był to worek płócienny o kształcie ściętego stożka, który wyrzucony za burtę samolotu i holowany za nim na długiej linie imitował samolot nieprzyjacielski wykonujący ewolucje. 
dowania, ćwiczenia w nawiązaniu łączności między pilotem a bombardierem $^{14}$, ćwiczenia bombardowania na strzelnicy bombardierskiej. Na I roku podchorążowie kończyli zajęcia $z$ bombardowania następującymi ćwiczeniami w powietrzu i w ciemni bombardierskiej ${ }^{15}$ :

1. Lot w łożu wiatru nad ciemnią $z$ pomiarem czasu przelotu. 2 przeloty $z$ wiatrem i 2 pod wiatr. Przeloty wykonywano na wysokości $500 \mathrm{~m}$.

2. Identyczne ćwiczenie wykonywane na wysokości $1000 \mathrm{~m}$.

3. Bombardowanie nad ciemnią bombardierska. Lot był wykonywany na wysokości $1500 \mathrm{~m}$.

4. Powtórzenie ćwiczenia na wysokości 2000, a później $3000 \mathrm{~m}$.

5. Bombardowanie $z$ wysokości $1000 \mathrm{~m}$ dwiema bombami ćwiczebnymi. Zrzut bomb wykonywano pojedynczo.

6. Powtarzano to ćwiczenie $z$ wysokości $2000 \mathrm{~m}$.

${ }^{14}$ Zajęcia prowadzono na tzw. wyżce bombardierskiej. Nie wchodzac w szczegóły techniczne i dokładne omówienie imitacji bombardowania na tym trenażerze, należy wspomnieć, że było to zaciemnione pomieszczenie w Dziale Nauk, w którym obserwatorzy ćwiczyli zrzut bomb. Kabina samolotu $z$ załoga była na rusztowaniu kilka metrów nad przesuwajacym się płótnem przewijającym się między dwiema belami, imitującym ziemię z celami. Jako „bomby" służyły strzałki, które obserwator uwalniał $z$ wyrzutnika bomb po wypracowaniu decyzji bojowej o zrzucie. Strzałki wbijały się w przesuwajace się płótno z namalowanymi celami.

${ }^{15}$ Autorowi udało się odtworzyć opis i metody szkolenia w „wyżce bombardierskiej” $\mathrm{i}$ „ciemni bombardierskiej” na podstawie opracowania Adama Popiela, Uzbrojenie lotnictwa polskiego 1918-1939, Wydawnictwo Czasopism i Książek Technicznych SIGMA-NOT, Warszawa 1991, jednych z niewielu zachowanych współcześnie, przedwojennych podręczników „Szkoły Orląt”, kapitana obserwatora Stanisława Michowskiego, Zasady teorii i techniki bombardowania, Dęblin 1936 oraz majora pilota Andrzeja Kładko, Bombardowane lotnicze, Dęblin 1937. Ciemnię bombardierską optyczna stanowiło specjalne drewniane mobilne pomieszczenie, w którym pracował obserwator (później była to skrzynia o wymiarach 1,2 x $1 \mathrm{x}$ $0,8 \mathrm{~m} \mathrm{z}$ dołączonym płóciennym rękawem, przez który instruktor obserwator mógł prowadzić prace wewnątrz ciemni). W górnej sufitowej części umieszczony był obiektyw. Obiektyw rzucał nam obraz odwrócony, pomniejszony „zależnie od wysokości wszystkich przedmiotów znajdujących się nad ciemnią bombardierska, uwydatniając ich ruch względem ziemi" (S. Michowski, Zasady teorii i techniki..., s. 205). Obsługujacy ciemnię instruktor obserwator, uchwyciwszy poruszajacy się obraz samolotu (jego cień) na papierze milimetrowym rozłożonym na wypoziomowanym blacie stojącym na podłodze, wykreślał drogę samolotu względem ziemi. Instruktor mógł ocenić precyzję dokonanego nalotu samolotu na ciemnię. Przy tym urządzeniu można było przeprowadzić fikcyjne bombardowanie. Ćwiczący na pokładzie samolotu podchorą̇y obserwator, gdy podejmował decyzję o zrzucie bomb, dawał sygnał do obserwującego na ziemi przebieg nalotu drugiego instruktora. Instruktor pracujacy w ciemni zaznaczał ten moment (np. wystrzelenia naboju sygnałowego ) na wykresie. „Po dodaniu na wykresie odcinka drogi odpowiadającego czasowi spadania bomby otrzymywało się punkt trafienia, a więc ocenę bombardowania” (A. Popiel, Uzbrojenie lotnictwa..., s. 132). 
Na II roku SPL $z$ tego przedmiotu wykonywano ćwiczenia:

1. Bombardowanie 2 bombami ślepymi (ale pojedynczo) $z$ wysokości $2000 \mathrm{~m}$.

2. Bombardowanie 2 bombami ślepymi $z$ wysokości $2500 \mathrm{~m}$, a następnie również 2 bombami ślepymi $z$ wysokości $3000 \mathrm{~m}$ (każde bombardowanie wykonywano pojedynczym zrzutem bomby).

3. Bombardowanie nad ciemnia bombardierska. Nalot wykonywano z wysokości $1500 \mathrm{~m}$. Lot wykonywano grupowo (para lub kluczem samolotów).

4. Lot grupowy na bombardowanie ćwiczebne nad poligonem z 2 bombami ślepymi. Wysokość wykonania zadania $2500 \mathrm{~m}$.

Ponadto, podobny algorytm kształcenia i szkolenia w powietrzu zastosowano $z$ niżej wymienionych przedmiotów:

1. Aerofotografia. Podchorażowie zapoznawali się $z$ teorią i praktyką wykonywania i wykorzystywania zdjęć lotniczych dla potrzeb bojowych wojsk lądowych, marynarki i lotnictwa. W ramach tego przedmiotu odbywali praktyczne zajęcia w eskadrach ćwiczebnych SPL i pułków bojowych $z$ wykonywania zdjęć, ich obróbki, interpretacji i użycia $\mathrm{w}$ meldunku bojowym. Program SPL i SPRL przewidywał 8 ćwiczeń w zastosowaniu praktycznej wiedzy $z$ aerofotografii.

2. Radiotelegrafia. Podchorążowie SPL i SPRL część zajęć praktycznych odbywali w Porcie Lotniczym Dęblin i Radom-Sadków. Wykonywali praktyczne zajęcia $z$ łączności lotniczej na samolotach bombowych i liniowych.

3. Aeronawigacja. W czasie 60 godzin zajęć podchorażowie wykonywali minimum 6 lotów nawigacyjnych na samolotach szkolnych i bojowych.

Podchorażowie SPRL po ukończeniu szkoły przez dwa kolejne lata, powoływani na ćwiczenia $z$ cywila, odbywali praktyczne zajęcia $\mathrm{w}$ jednostkach bojowych, doskonaląc swoją wiedzę teoretyczna i praktyczna, by zostać promowanymi do stopnia podporucznika rezerwy ${ }^{16}$. Od 1935 do 1939 roku kandydaci na obserwatorów przygotowywani byli do wy-

${ }^{16}$ Powoływani byli w roku kalendarzowym minimum 1-2 miesiace na ćwiczenia do jednostek lotniczych, w których byli na przydziale mobilizacyjnym. 
konywania obowiązów oficerów taktycznych eskadr. Zmieniono również programy dla oficerów obserwatorów rezerwy, którzy od 1934 roku w Dęblinie odbywali 14-dniowe przeszkolenie w ramach „Szkoły Ognia”" W ramach szkolenia po części teoretycznej odbywały się bardzo intensywne zajęcia praktyczne w powietrzu - głównie ze strzelania powietrznego i bombardowania oraz korygowania ognia artylerii.

W latach 1935-1939 zmieniały się programy kształcenia obserwatorów i pilotów-podchorażych, kadry zawodowej i rezerwy lotnictwa. Miały na to wpływ doświadczenia $z$ eksploatacji samolotów liniowych P-23 „Karaś”, bombowych P-37 „Łoś” i raporty wywiadu na temat rozbudowy, szkolenia i sposobów zastosowania w walce lotnictwa niemieckiego i radzieckiego. Pierwsze zmiany zawarte były w „Instrukcji doskonalenia kadry zawodowej lotnictwa” wydanej w lipcu 1935 roku przez Ministerstwo Spraw Wojskowych. Ostatecznie nowa doktryna kształcenia i szkolenia kadr lotniczych została zawarta w "Instrukcji wyszkolenia lotnictwa” z lipca $1937 \mathrm{r}$.

Podchorążowie-obserwatorzy rozpoczynający naukę od 1938 roku już w czasie zajęć w SPL realizowali program szkolenia taktycznego w powietrzu $z$ elementami zastosowania bojowego. Podchorażym zmieniono także czas trwania studiów, by mogli wcześniej już w jednostkach bojowych zdobywać doświadczenie np. jako obserwatorzy w zakresie:

a) dowodzenia samolotami bombowymi i liniowymi;

b) aeronawigacji w dzień i w nocy;

c) obsługi i wykorzystywania w dowodzeniu i w walce pokładowych środków łączności;

d) przygotowania do walki w powietrzu jako obserwator, strzelec pokładowy, bombardier.

Efektem zmian w kształceniu obserwatorów było bardzo szybkie skompletowanie w 1939 r. załóg lotniczych Brygady Bombowej i eskadr liniowych. Poziom przygotowania zawodowego załóg nie w pełni mógł być wykorzystany na naszym sprzęcie lotniczym we wrześniowych walkach 1939 roku $z$ Luftwaffe. Osiagnięcia w walkach we Francji w maju 1940 roku, a później w Anglii potwierdziły skuteczność bojowego przygotowania s. 44-47.

${ }_{17}$ Program przeszkolenia opisał autor w opracowaniu Kształcenie obserwatorów..., 
obserwatorów, bombardierów, strzelców pokładowych-radiotelegrafistów z lat 1937-1939 w dęblińskiej „Szkole Orląt”.

Jeśli przeanalizujemy przygotowanie pilotów do września 1939 roku, to pomimo wstrzymania kształcenia w pilotażu podchorażych SPL do 1934 roku szkolono w tej specjalności podchorażych rezerwy (od 1928 r.), a w 1929 roku Oficerów-obserwatorów z SPL w Dęblinie oraz absolwentów innych szkół podchorążych na Kursach Pilotażu dla Oficerów Młodszych Lotnictwa. Niestety, większość wyszkolonych pilotów i obserwatorów rezerwy nie została zmobilizowana we wrześniu 1939 roku.

Rozpoczęcie kształcenia podchorążych SPL w Dęblinie w pilotażu w 1935 roku poprzedzone było szeregiem zmian w programach kształcenia pilotów w SPRL, Kursu Pilotażu dla Oficerów Młodszych Lotnictwa w Dęblinie i Szkoły Podoficerów Pilotów w Bydgoszczy. Dotychczasowe szkolenie w pilotażu wstępnym ${ }^{18}$ skrócono do minimum. Dla większości podchorażych było to sprawdzenie ich umiejętności pilotażowych, jakich nauczyli się w szkołach pilotażu szybowcowego, a później samolotowego Ligi Obrony Powietrznej Państwa.

Zwiększono zakres szkolenia - dotychczasowego drugiego etapu w pilotażu przejściowym (zwanym również podstawowym). W tym etapie szkolenia podchorąży-pilot wykonywał m.in. loty na samolotach szkolno -akrobacyjnych, opanowując sztukę pilotowania samolotu $z$ wyższej akrobacji lotniczej. Dopiero na tym etapie dokonywała się wtórna selekcja pilotów do trzeciego poziomu kształcenia pilotów na samolotach myśliwskich i liniowych ${ }^{19}$.

Piloci samolotów liniowych w SPL na trzecim poziomie doskonalenia w pilotażu realizowali pełny program strzelania powietrznego, poszerzony

\footnotetext{
${ }^{18}$ Nazwa pierwszego poziomu szkolenia lotniczego prowadzonego w szkolnictwie lotniczym w wojsku.

${ }^{19}$ Do 1935 r. drugi etap szkolenia w pilotażu obejmował loty tylko na samolotach przejściowych, a loty na samolotach akrobacyjnych odbywały się w Wyższej Szkole Pilotów. W trzecim etapie szkolenia (do 1935 r.) doskonalono pilotaż na samolotach liniowych i wyselekcjonowano niewielka grupe pilotów myśliwskich, którzy pełne przeszkolenie odbywali w Lotniczej Szkole Strzelania i Bombardowania w Grudziądzu. Szerzej na temat metodyki szkolenia w okresie przedwojennym napisał autor w artykule: Przedwojenne metody szkolenia $w$ zakresie pilotażu $w$ polskim lotnictwie wojskowym, w: Humanistyczne (pozatechniczne) konteksty przygotowania zawodowego do pracy $w$ warunkach trudnych i niebezpiecznych, red. S. Ślusarski, Wydawnictwo Wyższej Szkoły Oficerskiej Sił Powietrznych, Dęblin 2014, s. 361-379.
} 
program bombardowania, lotów grupowych, nawigacyjnych oraz startów i lądowań na lotnisku polowym.

Piloci samolotów myśliwskich w SPL, kończąc Szkołę, byli wyszkoleni zgodnie $z$ programem Kursu Wyższego Pilotażu. Ich poziom wiedzy teoretycznej i umiejętności w pilotażu dorównywał wyszkoleniu pilotów pułku bojowego (całkowite wyszkolenie $z$ akrobacji lotniczej, walki powietrznej, lotów grupowych eskadra, posługiwania się radiostacja).

W czasie trzech lat studiów podchorążowie-piloci kształcili się w systemie studiów przemiennych i mieli zajęcia teoretyczne wraz z nauka na sprzęcie lotniczym (budowa i eksploatacja silnika, płatowca, uzbrojenia, fotografia lotnicza, łączność) od października do marca. Intensywnie szkolili się w powietrzu od kwietnia do października.

Od 1938 roku skrócono realizację programów kształcenia i szkolenia lotniczego tak, by przyśpieszona o półtora roku XIII, a o dwa lata XIV promocja podchorą̇ych zasiliły polskie lotnictwo 65 pilotami liniowymi, 102 pilotami myśliwskimi, 46 w pełni wyszkolonymi obserwatorami i ok. 140 pilotami wyszkolonymi na drugim poziomie szkolenia w pilotażu.

W starciu z niemiecka Luftwaffe absolwenci „Szkoły Orlatt”, tak jak cały personel polskiego lotnictwa, wypełnili swoje zadanie ponad rzeczywiste możliwości. W czasie 17 dni walk we wrześniu 1939 roku, przy dysproporcji sił 1 : 5 na niekorzyść naszych 400 załóg lotniczych, zniszczono ok. 100 samolotów niemieckich i drugie tyle poważnie uszkodzono. Szczególnie należy podkreślić fakt, że we Francji i Anglii walczyło 780 pilotów i obserwatorów „Szkoły Orląt”, co stanowiło 66\% jej wszystkich absolwentów promowanych w latach 1927-1939.

Sukcesy, jakie odnosili polscy piloci w walkach powietrznych i w czasie bombardowań, były zasługa ich bardzo dobrego przygotowania ogólnokształcącego i specjalistyczno-lotniczego. Na przeszkolenie w pilotażu i przygotowanie do walki na samolotach francuskich nasi piloci potrzebowali $20 \mathrm{dni}$, a niewiele więcej na sprzęcie brytyjskim.

W Polskich Siłach Powietrznych na Zachodzie personel latajacy oprócz udziału w działaniach bojowych był systematycznie dokształcany w polskich oraz brytyjskich szkołach i centrach szkolenia. Uzyskane w wyniku działań bojowych i edukacji ich osiagnięcia są wkładem w rozwój polskiej dydaktyki lotniczej. Wiele $z$ tego, co było polskim wkładem $\mathrm{w}$ aliancki system przygotowania personelu latającego do walki, powinno 
być przedmiotem badań w zakresie dydaktyki, zwłaszcza że polscy piloci $\mathrm{i}$ inżynierowie uczestniczyli w brytyjskim programie badawczym dotyczacym samolotów odrzutowych.

Wiele aspektów odnoszących się do metodyki szkolenia bojowego na różnych typach statków powietrznych, psychologii walki pilota, jego zachowania się w skrajnie wyczerpujacych warunkach walki powietrznej jest przedmiotem naszych badań.

Czynione sa starania, by odbudować zaburzony po wojnie (do 1956 r.) naturalny rytm przekazywania młodszym pokoleniom pilotów przez starsze generacje lotnicze doświadczeń lotniczych i kształtowania lotniczych postaw.

Przyjęcie Polski do NATO w 1999 roku spowodowało zmiany jakościowe w naszym lotnictwie w zakresie wyposażenia w sprzęt lotniczy i kształcenia personelu latającego, kontrolerów ruchu lotniczego i nawigatorów.

Od 2005 roku „Szkoła Orląt” w Dęblinie stała się pełnoprawnym podmiotem już jednolitego szkolnictwa wyższego kształcącym studentów wojskowych i cywilnych ${ }^{20}$.

Ze względu na specyfikę kształcenia wojskowego kadr lotniczych oraz cywilnego personelu pilotów i kontrolerów aktualnie obowiąujące plany i programy ich nauczania zostały opracowane na podstawie cywilnych i wojskowych aktów normatywnych. Na przykład dostosowano wymogi kształcenia licencjonowanych pilotów z uprawnieniami IFR (CPL/ IR) do standardu kształcenia magistra inżyniera na kierunku studiów „lotnictwo i kosmonautyka”. Działalność Akademickiego Ośrodka Szkolenia Lotniczego odpowiedzialnego za przygotowanie podchorażych i studentów cywilnych do cywilnej licencji pilota podlega cyklicznym audytom Urzędu Lotnictwa Cywilnego. Podobnym audytom podlega certyfikowany Ośrodek Kształcenia Kontrolerów Ruchu Lotniczego WSOSP.

W WSOSP od 2002 roku w Katedrze Nauk Ogólnokształcacych wprowadzono zmiany w programach kształcenia m.in. z psychologii, pedagogiki, komunikacji społecznej, socjologii, historii sztuki wojennej, historii lotnictwa, przywództwa w dowodzenia, działalności wychowawczej w wojsku. Dotyczyły one głównie problematyki przygotowania zawodowego

${ }^{20}$ Do 2005 r. wojskowe uczelnie podlegały przepisom wojskowego prawa o szkolnictwie wyższym. 
podchorążych-pilotów, kontrolerów, nawigatorów do nowych zadań lotnictwa m.in. w misjach stabilizacyjnych za granica.

Wprowadzono do programu kształcenia nowy przedmiot: „człowiek jego możliwości i ograniczenia" (90 godzin) jako przygotowanie do tematyki późniejszego doskonalenia pilotów i nawigatorów latających w jednostkach w zakresie współpracy w załodze wieloosobowej (MCC) oraz zarządzania zasobami załogi (CRM) i ryzykiem operacyjnym (ORM) ${ }^{21}$. Zmieniały się wymagania w stosunku do personelu latającego w zakresie znajomości języków obcych.

W porównaniu do poprzednich programów zajęć $z$ języków obcych o 40\% zwiększono liczbę godzin dydaktycznych w tym zakresie. W nowym programie zajęcia głównie $z$ języka angielskiego obejmuja 480 godzin, a podchorażowie podlegaja procedurom egzaminacyjnym zgodnie ze standardem NATO - Stanag 6001. Dodatkowo podchorażowie maja 45 godzin zajęć w zakresie „frazeologii lotniczej w języku angielskim”.

Dęblińska „Szkoła Orląt” ma unikatowe doświadczenia w kształceniu personelu latającego. Jej struktura organizacyjna, sposoby przekazywania wiedzy wraz ze stopniem automatyzacji, informatyzacji zmienia się tak jak technika lotnicza.

Samoloty kolejnych generacji to swoiste cudo aeronautyki, ale współczesne szkolenie lotnicze w dużym stopniu może korzystać $z$ dorobku poprzednich pokolen.

${ }^{21}$ Od 2012 r. oprócz zajęć teoretycznych i treningów rozpoczną w ramach tego przedmiotu ćwiczenia praktyczne prowadzone przez pilota instruktora na symulatorze lotniczym do szkolenia CRM i MCC. Szerzej na ten temat napisał J. Ślusarski, Kluczowe wymagania zawodowe warunkujace powodzenie pilota i pilota- instruktora wojskowego statku powietrznego $w$ procesie szkolenia lotniczego określone na podstawie analiz stanowiska pracy, w: Humanistyczne (pozatechniczne)..., s. 110-112. 
Słowa kluczowe: kształcenie lotnicze, szkolenie specjalistyczne, piloci, obserwatorzy

\title{
SPECIALIST EDUCATION OF FLYING STAFF IN THE "EAGLET SCHOOL" BETWEEN 1925 AND 1939
}

\begin{abstract}
Summary
Flying staff education in the "Eaglet School" in Dęblin began in 1925. In the result of WWII. most experiences from our pre-war aviation didactic, considering losses of lecturers and pilots as well as observers-instructors, have been forgotten. Plans, programs, school books and instructions were destroyed. In the article a part of research results, conducted on the subject in the Laboratory of War Art History and Aviation Didactic of the Air Force Academy in Deblin, have been presented.
\end{abstract}

Keywords: aviation didactic, special training, pilots, observers 
INFORMACJE, RECENZJE 



\section{Oxana Kozlova}

Uniwersytet Szczeciński

\section{Świat korowodu \\ w spektaklu Jerzego N. Grzegorka Korowód w Fado i w jego możliwym zasięgu}

W marcu 2015 roku w Akademickim Centrum Kultury Uniwersytetu Szczecińskiego został wystawiony spektakl Korowód $w$ Fado. Nie po raz pierwszy, bo przedstawienie powstało w 2014 roku w wyniku, jak pisze jego autor, „ludzkiej otwartości na zmianę” - przede wszystkim wśród organizatorów przedstawienia, czyli Teatru Ruchu Umownie Ewidentnego, Biura ds. Osób Niepełnosprawnych US, Akademickiego Centrum Kultury US i Fundacji Szansa dla Niewidomych. W swym oddziaływaniu przedstawienie sprzyja wzrostowi otwartości na zmianę wszystkich widzów, poszerzenie Korowodu jest formą połączenia ludzi w procesie twórczym.

Organizowany przez Jerzego Grzegorka Korowód tworza osoby niewidome i niedowidzące, których ruch opiera się na technice kontaktu i improwizacji. Widzimy, jak tworzy się i powtarza - zawsze inaczej i poprzez improwizację - kontakt, który demonstruje niezwykle przejrzyście rozumienie tego, że chodzi o wieczny, uniwersalny sposób tworzenia życia społecznego. Że cały rozwój społeczeństwa to proces kontaktowania się improwizatorów, jak również to, że improwizacja - jako samoaktualizacja podmiotu - nie ma żadnego sensu bez kontaktu.

Ciekawa scenografia powoduje urozmaicenie sposobów improwizacji - samoaktualizacji artystów i wszystkich uczestników Korowodu. Forma korowodu została tu wykorzystana jako sposób organizacji procesu dzielenia się energia spotkania. Działa to też jako sprawdzian dla widzów ich umiejętności otworzenia się na innego, na jego unikatowość. Staje się tu jasne, że najczęściej umiemy widzieć w niewidomym człowieku tylko jedno - że jego oczy nie widzą - i to radykalnie nas rozróżnia. Zwykle bliżej już nie idziemy, tylko pracujemy nad tym, żeby nie okazać swojego po- 
czucia obcości. Przedstawienie zaś spowodowało posunięcie - prawie nauczyliśmy się nie odsuwać energetycznie, wiemy, że chcemy się starać nie pokazywać swojej obcości osobom niepełnosprawnym. Przed nami kolejny krok - nauczyć się otwierać, spotykać się, komunikować, prowadzić dialog. Dopiero to będzie oznaczało obalenie naszej wzajemnej alienacji.

Korowód $w$ Fado, wystawiony i rozpoczęty przez Jerzego Grzegorka jako proces otwarcia odwołującego się do jednej $z$ najbardziej archaicznych form komunikacji, jest jednocześnie całkowicie nowoczesny, stwarza tak ponowoczesną sytuację performance'u. Ale jeżeli zwykle performance dąży do zaskoczenia i poruszenia publiczności, to ten korowód najwyraźniej dąży do poruszenia w nas umiejętności nie ograniczania się zaskoczeniem, lecz pójścia dalej - wkroczenia do wspólnej przestrzeni spotkania, współdziałania, tworzenia więzi - i tym samym poszerzania przestrzeni o tyle, o ile pozwala nam nasz „wymiar wolności twórczej”.

Wybór muzyki powoduje pogłębienie pomysłu, nadaje jeszcze większy sens procesowi dzielenia się energia spotkania. Ponieważ muzyka fado, czyli przeznaczenia (piękne portugalskie „nostalgiczne pieśni”), określa charakter tej energii, która z nami dzielą się uczestnicy korowodu, wprowadzajac temat Saudade jako specyficzny dla kultury portugalskiej i galicyjskiej sposób postrzegania rzeczywistości. Kluczowa rolę odgrywa w nim waloryzacja przeszłości, kontemplacja przemijania odbieranego $z$ subtelną dumą i radością, w sposób pozytywny.

I tu być może jest akurat ten przypadek, kiedy specyfika jednej kultury okazuje się specjalnie ważna i potrzebna dla całej ludzkości. Być może nie będziemy mogli przeżywać Saudade właśnie tak, jak to przeżywaja Portugalczycy, ale wszyscy jesteśmy wzbogaceni możliwościa takiego sposobu przeżywania, wszyscy jesteśmy nim obdarowani.

Korowód to więcej niż taniec - to obrzęd komunikacji, którego tradycyjność, a nawet archaiczność nie przeszkadza temu, że jego rola w nowoczesności rośnie. Powstały w drugiej połowie XX wieku stosunek do korowodu jako do rudymentu folklorystycznego, formy nieaktualnej widocznie się zmienia. Teraz, jak się okazuje, rośnie zapotrzebowanie na kluczową w tej komunikacji wspólnotowość jako sposób na ratowanie, uzdrowienie przyszłości za pomoca przeszłości, za pomoca wznowienia pamięci i wrażliwości. Każdy włączający się w korowód daje sobie czas na 
bycie razem $z$ innymi, na bycie dla innych - i tym samym staje się współtwórca Świata Korowodu.

Świat Korowodu może się wydawać utopią, dziwactwem nieracjonalnie nierozsądnych, opóźnionych, nienadążających i dlatego nieobecnych w Świecie Wyścigów. Bo w tym ostatnim niepodważalnymi prawdami sa takie "aksjomatyczne” klisze: "Czas to pieniądz”, „Światem rządza liczby”, „Najpierw musi być zysk”. Ale dzisiaj już zdaliśmy sobie sprawę $z$ tego, że właśnie takie przyśpieszające nasze życie prawdy generalnie destabilizuja je.

Stworzenie rzeczywistości zrównoważonej, której metafora jest korowód, opiera się na określeniu zony odpowiedzialności, tzn. zony naszej wrażliwości. U tego, komu obce sa problemy innych, staje się zona taka minimalna, a zjawisko „korozji charakteru” (pojęcie wprowadzone i opisane przez Richarda Sennetta) - totalne. Wrażliwość poszerzajaca się przez otwieranie na innych, na wszystkich, tworzacych piękno różnorodności życia niewatpliwie sprzyja wzmocnieniu i uzdrowieniu charakteru.

Może dwa światy powinny istnieć obok siebie? Przypuśćmy, wyobraźmy sobie, umodelujmy taki układ: po jednej stronie ci skuteczni konkuruja i produkuja konkursy, zajmuja się swoim biznesem, swoja praca, liczeniem liczb i zysków; zaś po drugiej ci marzyciele tańczą w korowodach, bawia się i wzruszaja, ciesza się życiem jako oddawaniem, obdarowywaniem. Ci pierwsi sa stanowczo przekonani, że wszystko się dzieje dzięki nim i ich kosztem. Ale czy tak jest naprawdę?

Wbrew pozorom mainstreamowym właśnie przeżywanie, emocjonalna wrażliwość jest podłożem ontologicznym życia społecznego, istnienia świata racjonalniepragmatycznego. To można pokazać też z innej strony, z przeciwnej - modelując świat materialny całkowicie oczyszczony z przeżyć, marzeń, oczarowań, całkowicie i ostatecznie odczarowany. Oczywiste jest, że taki świat bezdusznego istnienia w wielkiej ilości nagromadzonej materialności nie żyje, może być tylko „martwą natura” społeczeństwa.

Jednak rzeczywistość jest bardziej skomplikowana niż ten model. Bo oba światy - zarówno Korowodu, jak i Wyścigu - znajduja się nie na zewnątrz, tylko w każdym $z$ nas, tworzą konflikt wewnętrzny każdego $z$ nas, a zarazem i całej naszej cywilizacji. Jak powiedział Grigori Pomieranc, „nie można uwolnić osobowości słabo rozwiniętej”. Swoboda od stereotypowego - wyścigowego - postrzegania rzeczywistości bazuje na 
intensywnej pracy wewnętrznej. I wrażliwość całego społeczeństwa rozwija się. Teraz, z wysokości powszechnego alfabetyzmu, jaśniej widzimy profanacje, udawanie, manipulacje - lub szczerość. Ale nadal pozostaje aktualne zadanie: uatrakcyjnić dobro, zbliżyć je do tych, którzy być może jeszcze nie znaja swojej potrzeby tego dobra, tej - w naszym temacie - rozkoszy obcowania i obdarowywania się. Warto w procesie wypracowania nowych potrzeb uwzględniać teoremat Thomasa: „Jeżeli ludzie definiuja jakieś sytuacje jako rzeczywiste, staja się one rzeczywiste poprzez swoje konsekwencje”. Jeżeli widzimy nasza komunikacje jako nasze wzbogacenie, staje się ona w konsekwencji wzbogaceniem. Ale dla tego potrzebna jest otwartość i szczerość, obalenie bariery własnej ironiczności jako sposobu unikania trudu postrzegania głębi zjawisk, pozostania na ich powierzchni.

Połowa tworzacych korowód i prowadzących improwizacyjny dialog w tonalności fado osób niepełnosprawnych jest niewidoma od urodzenia. Sama ich obecność na scenie oznacza wielowymiarowe zwycięstwo społeczeństwa XXI wieku. Zwycięstwo wspólne:

a) osób, które nauczyły się pomagać niepełnosprawnym jako ludziom, czyli istotom kreatywnym, twórczym;

b) osób, które przełamujac niepewność (spróbujmy tylko wyobrazić sobie, jak totalna, bo wynikajacca ze zrozumienia swojego niepodobieństwa do innych) siebie i świata, wchodza w korowód samorealizacji przez sztukę, przyjmując tym nie tylko pomoc w zaspakajaniu potrzeb fizjologicznych lub bezpieczeństwa (taka pomoc oferujemy też zwierzętom domowym), lecz również pomoc w zaspokajaniu potrzeby miłości, przynależności, szacunku, uznania, potrzeb spełnienia swojego potencjału;

c) tych wszystkich, którzy otaczaja korowód, widzów, którzy ucza się spotykać i nie odwracać się, komunikować się z naprawdę innymi ludźmi, sprawdzaja i rozwijają własną wrażliwość, kształtują umiejętność uczestniczenia w uniwersalnych, podstawowych przeżyciach - w przeżywaniu zimy, ciepła, miłości, zwycięstwa.

Uczestnicząc w przedstawieniu, wzruszamy się i jesteśmy szczęśliwi. Lub odpuszczamy sobie trud otworzenia się na innych i nudzimy się nadal w pośpiechu i komforcie. Tylko nowa sytuacja zaostrza problem szkodliwości obojętności. Globalizacja doprowadza do sytuacji, w której 
pozycja „ani sojusznicy, ani przeciwnicy” traci sens. Lekka powierzchowność oznacza brak zrozumienia. Bo rozumienie rzeczywiste to zrozumienie innego, i inaczej być nie może.

Jak pokazywał Jean Baudrillard, współczesność produkuje „światopogląd-light" zwolniony $z$ wrażliwości (Keep calm and be mainstream). Ale może być i inna lekkość, osiagana przez oczyszczenie od drobiazgowości, wypracowanie jasnej wizji rzeczywistości i jej kluczowej charakterystyki ona jest wspólna i piękna dzięki swojej różnorodności. 



\section{Barbara Chojnacka \\ Julia Magdalena Karapuda}

Uniwersytet Szczeciński

\section{Sprawozdanie z XXIX Letniej Szkoły Młodych Pedagogów, 14-19 września 2015 r., Pułtusk-Warszawa}

W Pułtusku, mieście położonym w północnej części Mazowsza w odległości około $60 \mathrm{~km}$ od Warszawy, na skraju Puszczy Białej, na szlaku prowadzącym do jezior mazurskich, mieści się zamek biskupów płockich, którego historia sięga XV wieku. Wówczas to biskup Florian Laskary wzniósł pierwsze murowane elementy zamku na miejscu drewnianego grodu. W roku 1841 zamek przestał być siedzibą biskupów, wielokrotnie zmieniając swoje przeznaczenie $\mathrm{w}$ późniejszych latach, a podczas walk w czasie II wojny światowej spłoną. W 1989 roku po zakończeniu trwajacej 15 lat odbudowy zamek został przeznaczony na „Dom Polonii”, który na pięć dni, 14-19 września 2015 roku, stał się siedzibą XXIX Letniej Szkoły Młodych Pedagogów.

Jak co roku patronat nad Letnia Szkoła obją Komitet Nauk Pedagogicznych PAN, natomiast kierownikiem naukowym po raz dwudziesty drugi była wiceprzewodnicząca KNP PAN prof. Maria Dudzikowa. Rolę gospodarza pełnił Wydział Nauk Pedagogicznych Akademii Pedagogiki Specjalnej w Warszawie $z$ dziekanem dr. hab. prof. APS Maciejem Tanasiem. Sekretarzem Naukowym XXIX LSMP, prezydentem Forum Młodych Pedagogów pod patronatem KNP PAN kadencji 2014/2015 została dr Marta Krasuska-Betiuk przy wsparciu członków komitetu organizacyjnego: dr Sylwii Galanciak, dr Małgorzaty Jabłonowskiej, dr Agnieszki Pawlak, dr Agnieszki Olechowskiej, dr Urszuli Markowskiej-Manista, dr Katarzyny Pardej, dr Anny Andrzejewskiej, mgr Katarzyny Korbeckiej i mgr Moniki Gałkowskiej.

Jak podkreślają organizatorzy, podstawowym celem Letnich Szkół jest wspieranie i stymulowanie rozwoju naukowego młodych pedagogów, 
a także tworzenie okazji do uzupełniania i pogłębiania wiedzy, bogacenia własnego warsztatu badawczego oraz prezentacji osiagnięć naukowych. Nie mniej ważne jest tworzenie warunków sprzyjających integracji środowiska i zacieśnianiu więzi międzypokoleniowej. Corocznie pięciodniowa Szkoła pozwala młodym naukowcom spotkać się z profesorami reprezentującymi ośrodki naukowe $z$ całej Polski oraz poszukiwać odpowiedzi na pytanie, jak najlepiej konstruować własny zamysł badawczy, a także w jaki sposób realizować własne badania. Uczestnicy Szkoły maja możliwość udziału w wykładach, dyskusjach panelowych, warsztatach, a przede wszystkim w konsultacjach $z$ Mistrzami.

Problematyka tegorocznej Szkoły skoncentrowana została wokół tematu: Oposzukiwaniu, poznawaniu i tworzeniu samego siebie. Teoretyczna i praktyczna perspektywa. Praca nad soba zwiazana $z$ samowiedza, samoświadomością i doświadczaniem siebie stała się jedną z priorytetowych kwestii dotyczacych podmiotowości współczesnego człowieka. Tematykę tę uszczególawiano poprzez poszukiwanie odpowiedzi na pytania:

1. Jaki rodzaj aktywności można nazwać praca nad sobą i jakie realia psychospołeczne leżą u jej podstaw?

2. Do jakich możliwości zawartych w psychice człowieka i świecie zewnętrznym należy się odwołać, aby móc wyłonić struktury tej aktywności?

3. Spełnienie jakich warunków jest niezbędne, by człowiek chciał i podejmował twórcza pracę nad sobą?

4. W jaki sposób można tworzyć samego siebie, a także przybliżać uczniom/studentom ideę i praktykę samodoskonalenia?

Otwarcia XXIX Letniej Szkoły Młodych Pedagogów, powitania uczestników i zaproszonych Gości dokonał dziekan Wydziału Nauk Pedagogicznych APS, dr hab. prof. APS Maciej Tanaś oraz przewodniczacy KNP PAN, prof. zw. dr hab. Bogusław Śliwerski. Władze Miasta reprezentowała Róża Krasucka, zastępca burmistrza Miasta Pułtusk. Następnie zgodnie z tradycja:

a) ubiegłoroczna Prezydencja LSMP dokonała wręczenia dyplomów „Strzał w dziesiątkę” (ks. prof. Marian Nowak, KUL, dr Marta Krasuska-Betiuk) oraz prezentacji opublikowanego Zeszytu Naukowego Forum Młodych Pedagogów przy Komitecie Nauk Pedagogicznych Polskiej Akademii Nauk - Zeszyt 19 „Opowiem Wam o Swojej Pasji: Słowem, Obrazem, Dźwiękiem..."; 
b) nastapiło uroczyste przekazanie insygniów Szkoły Gospodarzom XXX LSMP (w 2016 r.) - Wydziałowi Pedagogiki i Psychologii Uniwersytetu Ślaskiego.

Wprowadzenia w problematykę Szkoły dokonała prof. zw. dr hab. Maria Dudzikowa, a wykład inauguracyjny Budowanie wspólnoty $w$ nauce - ograniczenia $i$ szanse wygłosiła prof. Elżbieta Tarkowska (APS), która podkreśliła znaczenie relacji mistrz-uczeń dla budowania jedności nauki oraz zwróciła uwagę na masowości kształcenia akademickiego jako jednego z czynników jej zagrażających. Pierwszy dzień Szkoły został zakończony uroczysta kolacja, w trakcie której tradycyjnym momentem jest prezentacja wszystkich ośrodków naukowych (Poznajmy się bliżej).

Kolejne dni LSMP rozpoczynały się od porannej kawy/herbaty naukowej u prof. zw. dr hab. Marii Dudzikowej, podczas której młodzi adepci nauki mieli możliwość rozmowy $z$ kierownikiem naukowym Szkoły. Najbardziej inspirującą część dnia stanowiły wykłady Mistrzów połączone z dyskusja. W tym roku zaproszenie do udziału w LSMP przyjęli:

- ks. prof. Marian Nowak (KUL), Od pomagania w samowychowaniu do twórczej pracy nad soba - wspótczesne konteksty $i$ koncepcje;

- prof. B. Smolińska-Theiss (APS), Korczakowskie wołanie - „nauczycielu poznaj samego siebie zanim zaczniesz dzieci uczyć”;

- prof. Aleksander Nalaskowski (UMK), Autorska szkoła autorskie samowychowanie;

- prof. W. Szulakiewicz (UMK), Poszukiwanie madrości jako tworzenie samego siebie;

- prof. K. Ablewicz (UJ), Warsztat (Gestalt), Zobacz siebie, by zobaczyć drugiego;

- prof. B. Śliwerski (APS/UŁ), Krytycznie o teoriach/modelach samowychowania;

- prof. M. Dudzikowa (UAM), O nabywaniu kompetencji autokreacyjnych;

- prof. M. Czerepaniak-Walczak (US), O znaczeniu rozumienia własnej sytuacji $w$ procesie osiagania nowych praw i pól wolności akademickiej;

- prof. M. Karwowski (APS), Inteligencja akademicka jako cel autokreacji. Na własnym i cudzym przykładnie; 
- prof. K. Krasoń (UŚ), Sztuka jako integralne medium odkrywania sensu dla siebie. Trajektoria hermeneutyczna (na przykładzie pracy teatrem);

- prof. M. Dziemianowicz-Nowak (DSW), Narracje uznania jako droga do samego siebie. Perspektywa teoretyczna i empiryczna;

- prof. Z. Gajdzica (UŚ), O warunkach wspóttworzenia siebie i własnej drogi życiowej przez osoby niepetnosprawne;

- prof. J. Kirenko (UMCS), W poszukiwaniu siebie. Moje drogi życiowe;

- prof. T. Szlendak (UMK), O poszukiwaniu samego siebie w popkulturze;

- prof. M. Konopczyński z zespołem (Pedagogium), Twórczość w resocjalizacji jako droga poszukiwania samego siebie;

- dr M. Puchalska-Wasyl (KUL), Nasze wewnętrzne dialogi. O dialogowości jako sposobie funkcjonowania człowieka.

W części popołudniowej odbywały się tzw. Giełdy (p)różności, czyli wystapienia Młodych. Jako reprezentanci Uniwersytetu Szczecińskiego swoje referaty wygłosili: Małgorzata Kućko (Rozwój samowiedzy studentów jako wyzwanie dla edukacji wyższej), Jerzy N. Grzegorek (Somaestetyczne konteksty tańca współczesnego, czyli o trudnej sztuce tworzenia siebie jako tancerza) oraz Aleksander Cywiński wraz z Iwona Murawska z Uniwersytetu Mikołaja Kopernika w Toruniu (Spajając na nowo to, co rozbite. Dezintegracja pozytywna $w$ sferze uzdolnien artystycznych a trudny proces samokształcenia).

Do tradycji szkoły należy także „Dzień Gospodarzy”, który w tym roku uczestnicy LSMP spędzili w Warszawie. W części przedpołudniowej odwiedzili Akademię Pedagogiki Specjalnej i uczestniczyli w panelu dyskusyjnym z udziałem najwybitniejszych profesorów Wydziału Nauk Pedagogicznych APS. Przewidziano również czas na spotkanie $z$ pracownikami poszczególnych Katedr i Zakładów oraz uczestnikami $9^{\text {th }}$ International Summer School UNESCO APS (Readaptation and reintegration as problems of refugeechildren). W drugiej części odbyła się wizyta w I Społecznym Gimnazjum i Liceum im. Maharadży Jam Saheba Digvijaysinhji „Bednarska” w Warszawie oraz spotkanie $z$ dr Krystyna Starczewska oraz pracownikami szkoły. Wyjątkowość placówki polega na jej demokratycznym charakterze oraz otwartości na innych. Zarówno wśród kadry nauczycielskiej, pracow- 
ników szkoły, jak i wśród uczniów znajdują się przedstawiciele innych narodowości. Na zakończenie pobytu w Warszawie organizatorzy zaplanowali wizytę w Centrum Nauki Kopernik, w trakcie której przedstawiono realizowane tam projekty badawcze. „Dzień Gospodarzy” można określić mianem spotkania teorii $z$ praktyką edukacyjna, ponieważ uczestnicy LSMP mieli okazję pogłębienia wiedzy i wzbogacenia własnego warsztatu badawczego oraz podjęcia refleksji w kierunku pracy nad soba.

Podsumowaniem XXIX Letniej Szkoły Młodych Pedagogów była uroczysta kolacja pożegnalna, podczas której wręczono nagrody audytorium za najlepsze wystapienia w kategoriach magister i doktor oraz wyróżnienia "twórczy szum" i „twórczy szumek” dla osób aktywnych w dyskusjach. W tym miejscu na uwagę zasługuje „szczeciński sukces”, bowiem nagrodę za najlepsze wystapienie w kategorii magister oraz wyróżnienie „twórczy szum" otrzymał Jerzy N. Grzegorek. Wieczór obfitował w niespodzianki artystyczno-nostalgiczne przygotowane przez uczestników Szkoły, począwszy od XI Edycji „Limerykofraszkojady” po VII Edycję Kabaretu Behe-co? pod tytułem Maskarada na podstawie tekstów Iwony Murawskiej (UMK).

Letnia Szkoła Młodych Pedagogów okazała się inspirującym spotkaniem i niepowtarzalnym doświadczeniem akademickiej wspólnoty. Dziękując Wykładowcom-Mistrzom, Uczestnikom oraz Organizatorom XXIX LSMP, zachęcamy do udziału w przyszłorocznej, jubileuszowej XXX LSMP. 
